(10) \% 1 .

举

20,15

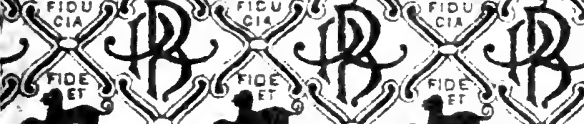

is is

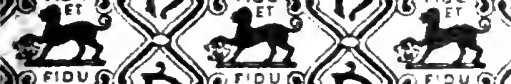

fos in

\% I I I

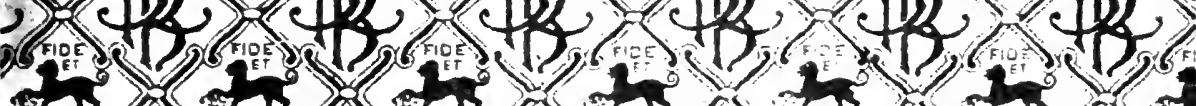

) 而

a)

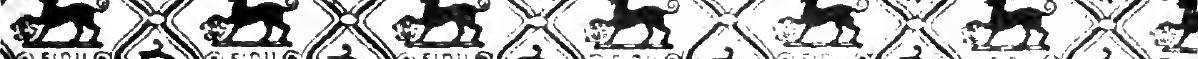
2)

(1)

Dof

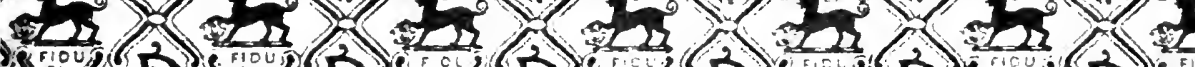
o(

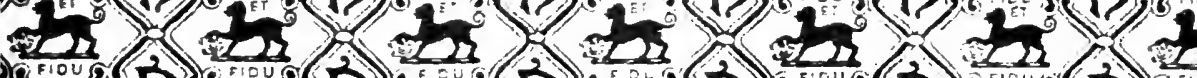

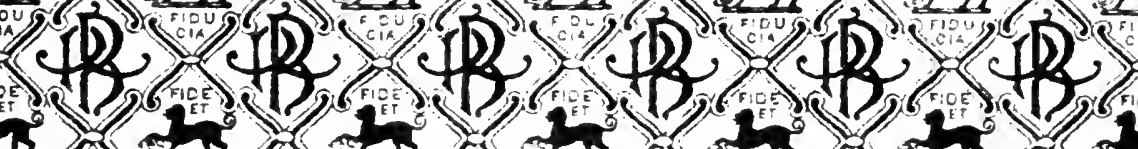

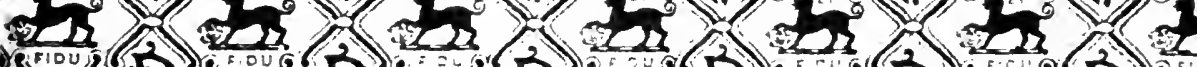

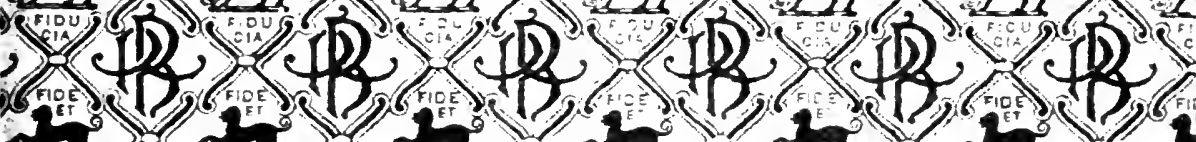

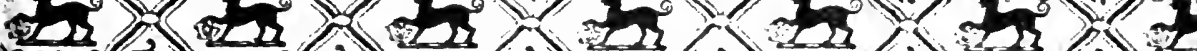

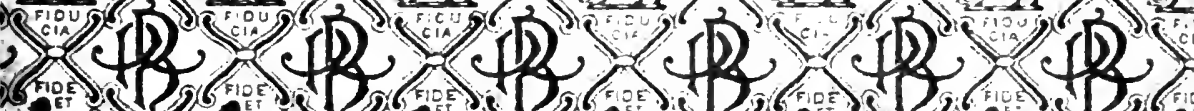
7. 1 (n)

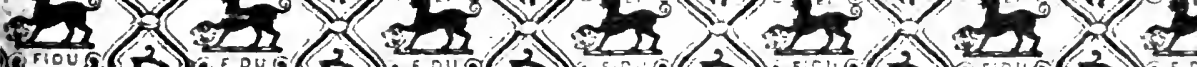

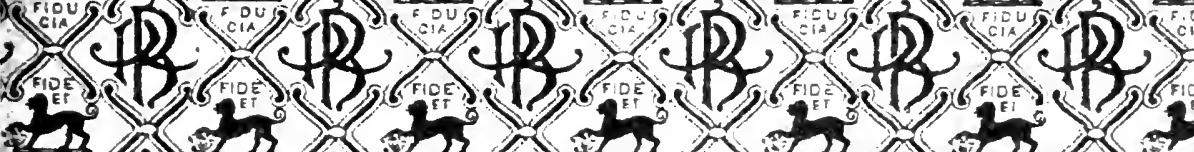

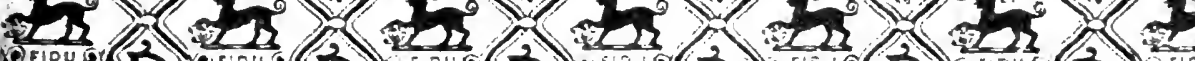

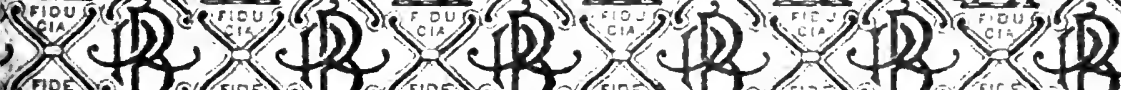

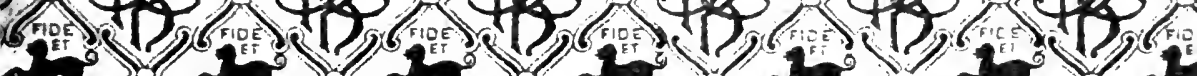

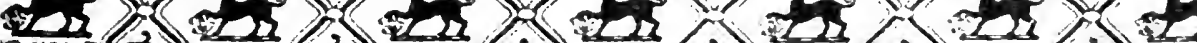


Digitized by the Internet Archive in 2007 with funding from Microsoft Corporation 
MY MUSICAL RECOLLECTIONS

Conseg School nom 

1 


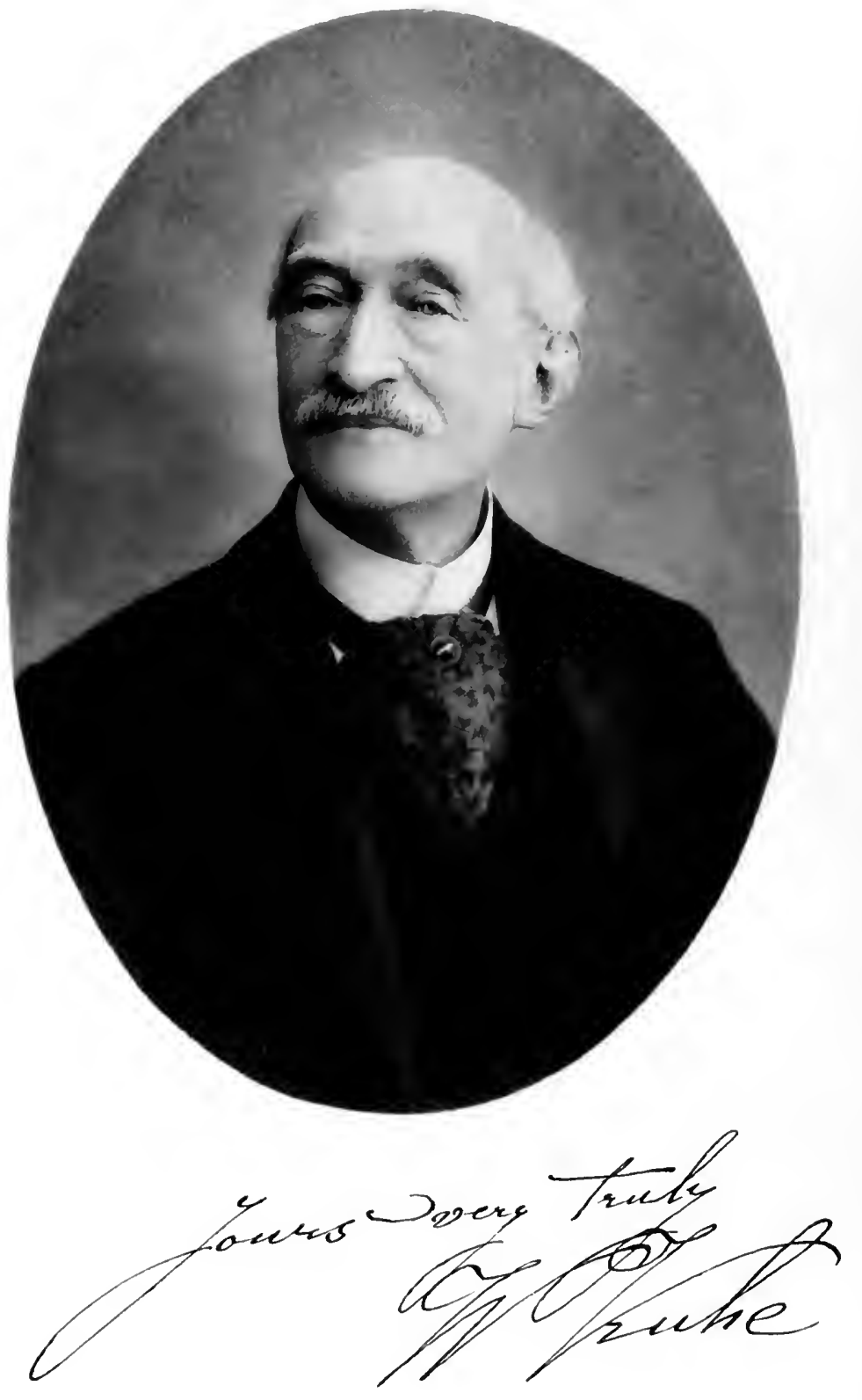




\title{
MY
}

\section{Musical RECOLLECTIONS}

\author{
$\mathrm{BI}$ \\ WILHELM KUHE
}

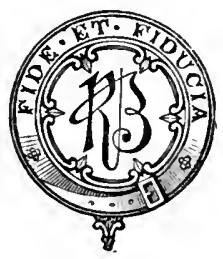

LONDON

R I C H A R D B E N T L E Y A N D S O N

Bnblishers in (Drdimary to ater attajesty

1896

[All rights reserved] 



\section{P R E F A C E.}

Some years ago, at a banquet of musicians, at which the wine was excellent and the music (with the exception of that which I contributed myself) execrable, I was called upon to make a speech. Having on several previous occasions intensified the melancholy of an after-dinner company in this fashion, I could not very well plead that I was 'unaccustomed to public speaking,' but I sought to be excused on the ground that, as I had enhanced the enjoyment of the assembly by playing one of my own compositions on the piano, it would be a pity to spoil the good impression thus created by taking also a share in the post-prandial oratory. But the chairman would listen to no such beautiful reasoning, and the next minute found me on my legs, delivering, with matchless grace, a speech in 
which I recalled a number of experiences that had befallen me in the course of my musical career.

Odd as it may seem, this volume of reminiscences would never have appeared had it not been for that dinner and my contribution to its toast-list. Briefly, what happened was this. A very distinguished confrère, whose name-lest my readers should bear him a grudge for evermore-I will not divulge, and who was among the convivial party, said to me that night : 'Have you ever thought of writing your musical recollections?' I replied that happily the idea had never occurred to me. Upon this my friend, who no doubt meant kindly, remarked that such a book as he had suggested would furnish very interesting reading, and he justified this seeming reflection on the intelligence of an enlightened public by declaring that most autobiographies commenced and ended with the pronoun personal. and that a volume written by a musician of other musicians with whom experience had brought him into contact would be something of a novelty. 'Think it over,' he added; 'I'm sure you are the man to do it.' 
Well, I did think it over, and having got the suggestion in my head, it became an idee fixe, but being a busy professional man, it has taken me a long time to develop the notion and carry it into execution. And now the result is to be seen in an unpretentious work written at leisure, and for the doubtless many defects of which I crave the indulgence of those of my friends who may glance through its pages and expect to discover in the author a raconteur of the first water.

But of whatever faults of omission and commission I may be found guilty, I hope, at least, to be acquitted of a charge of thrusting forward my own identity to the exclusion of other and far more interesting personalities in the world of music in which I have spent the greater part of my life. I have not forgotten the words spoken, perhaps in earnest, maybe in jest, by the brother artist who first tempted me to place on record the results of my association with celebrities past and present. I have sought to forget myself as often as possible, and now submit for lenient criticism my recollections of events and incidents in some of which I have had myself little or no active share. 
In a word, I dedicate to a public doubtless thirsting for information these pages, written, as my friend suggested, 'by a musician of other musicians.' 


\section{CONTENTS.}

\section{CHAPTER I.}

PRAGUE.

Early years in Prague-My parents and brother-Bridge PAGE over the Moldau-Edinburgh and Prague: a comparison-Charles $X$. in exile-The daughter of Marie Antoinette-Emperor Ferdinand crowned King of Bohemia-Gala performance at the Opera HouseMeyerbeer's $l l$ Crociato - Lavish expenditureMadame Schröder-Devrient - A German Mrs. Keeley

\section{CHAPTER II. \\ A LINK WITH THE PAST.}

An artistic rendezvous-Swoboda-Production of Don Giovanni at Prague-Status of Prague as a musical centre-Its orchestra and Conservatoire-Weber Kapellmeister-Mozart at Prague-His estimation of it musically-Rehearsing Don Giovanni-His words of approbation-Zerlina's scream-Original finale of the opera-Jubilee celebration at Prague-The first Pamina-Mozart's son-Cardinal Prince Schwarzenberg-Cardinal Prince Hohenlohe - - 6-I3

\section{CHAPTER III.}

\section{PAGANINI.}

My childish impressions of the violinist-A melody he played-Musical 'prodigies'-Paganini's miserly propensities-The laundress's bill-The violinist as a wit -Rebuke to his hostess--His kindness to Berlioz I 4- 7 


\section{CHAP'TER IV.}

EARLY MUSICAL MEMORIES.

My first lessons in music-Joseph Proksch's schoolWenzel Tomaschek-Holidays in Vienna-Hummel's and Moscheles' concerts in Prague-A droll appearance-King Louis of Bavaria-Mrs. Moscheles and her daughter-Kalkbrenner and his son-The Revolution of 1848 -Kälkbrenner's appearance and style of dress--His conceit--A duet with his son-An evening party-Chopin and Kalkbrenner-Thalberg - What he did for piano-playing-His Don Giovanni fantasia-l'he composer's bon mot-His appearance at my Brighton concert -

CHAPTER V.

\section{EARLY IIUSICAL MEMORIES}

(CONTINUED).

My master Tomaschek-His works and pupils-Dreyschock, Schulhoff-Hanslick, critic and friend of Brahms-Romberg, Servais, Bohrer-Regondi's virtuosity on the concertina - Clara Wieck - Clara Novello-Camilla Pleyel-Rubinstein - - 26-30

CHAPTER VI.

\section{PROFESSIONAL BEGINNINGS.}

Studies near Salzburg-First concert-tour-Metternich at Ischel, and later in Brighton-Munich-Franz Lachner-Interview with King Louis of BavariaAn entertaining Monarch-Stuttgart--The Queen of Wurtemberg-Pischek-Molique's advice as to visiting England-Pischek my fellow-traveller-Importunate officials

CHAPTER VII.

MUSICAL LONDON IN $\mathbf{1 8 4 5}$.

Arrival in the Metropolis-First impressions-Welcome from Moscheles and Benedict-First visit to $\mathrm{Her}$ Majesty's-'Long 'Thursdays'-Grisi, Mario, For- 
nasari, and Lablache in I Puritani-Expectations not PAGE wholly realized-Grisi criticized and compared-Mario - His contemporaries and successors-MorianiHausmann's friendliness - Madame Dulcken Musical critics of the day: J. IV. Davison, Morris Barnett, Gruneisen, Chorley - Stars of I 845 -Leopold de Meyer-Vieuxtemps-Alvars-Kellerman-Staudigl-Pischek's success-Madame Carradori AllenArtists and sense of pitch-A significant incident $3^{6-4^{2}}$

CHAPTER VIII. MUSTCAL LONDON IN 1845 (CONTINUED).

Henry and Walter Broadwood-J. B. Cramer-Joseph Ries-George and Frederick Rose-John and Algernon Black-A. J. Hipkins-Frederic Beale, an artpromoting publisher and concert-giver-Benedict's concerts - A programme of forty numbers - John Parry-His nervousness-Thalberg his great admirer -Mr. Ella's Musical Union-My first concert in England at the Beethoven Rooms-Alvars' amiability

CHA PTER IX.

SIMS REEVES.

Mr. J. M. Levy-Sunday Times-Compositions of Miss Levy-How I made my first appearance in London - Miss Lucombe-Emma's dilemma-Début of Sims Reeves-An unexpected success-John Braham'Wednesday Concerts' at Exeter Hall-Artists' salaries then and now - The losses of a gifted singer

- $49-55$

CHAPTER X.

SIR MICHAEL COSTA.

The composer's works-What he did for orchestral players - His love of punctuality-A story about his oboeplayer-Appreciation of the composer by the Royal Family - $5^{6-63}$ 


\section{CHAPTER XI.}

JENNY LIND.

My first impressions of her in $1846--$ Some of her operatic PAGE successes-Meyerbeer's Camp in Silesia-Its historical significance-An awkward law-How the difficulty was overcome-A new libretto for the opera- $L$ 'Etoile du Nord-A reminiscence of Patti-How Frederick the Great became Peter the Great-Jenny Lind at Her Majesty's Theatre in I 847-A memorable season -Seats at a premium

\section{CHAPTER XII.}

\section{JENNY LIND}

(CONTINUED).

Her private life-Acts of benevolence-An English tour in 1848 - $\mathcal{E}, 10,000$ given to charities-Kindness to brother and sister artists-How she came to sing for me at Mannheim-A lucky accident-Opposition happily averted - A generous offer-A memorable concert-The 'Swedish Nightingale'-Queen Adelaide-An evening at St. James's Palace-Gardoni and Lablache-A Royal assemblage - - 70-74

\section{CHAPTER XIII.}

\section{A BATCH OF CELEBRITIES.}

M. II. Balfe-Les Quatre Fils de Haymon-Madame Dulcken - Moscheles - Julius Benedict - Ferdinand David-Madame Dulcken's concerts and partiesAn incident at one of the latter-A luncheon to Mendelssohn - Benedict's hospitality - Lady Benedict-A happy event-Royal compliments thereonMoscheles and the composer of Elijah-The former's farewell recital-Camilla Pleyel-Return of the 'Wanderer'

\section{CHAPTER XIV.}

\section{LABLACHE.}

His Don Pasquale-A cab incident-A famous quartette -Lablache in private life-His sense of humour- 
His singing of 'buffo' songs-Operatic artists and the income-tax-Lablache's snuff-boxes-His son Frederic-

CHAPTER XV. JULLIEN.

His remarkable individuality - Promenade programmesGood value for money-British Army QuadrillesJullien as a conductor-What he did for music-Some famous instrumentalists-A season of English opera -Dorus Gras-Sims Reeves - Whitford JonesHector Berlioz-Balfe's Maid of Honour-Martha - A famous old lyric-Jullien's fate as operatic manager and composer-A short-lived opera-Anna Zerr-Jullien's detractors - $86-90$

\section{CHAPTER XVI.} EVENTS IN 1847 .

A record season-Lind and Gardoni-Rival opera-houses -Covent Garden enters the lists-Costa and his orchestra migrate thither-Balfe succeeds him at Her Majesty's - The pas de quatre-Alboni's débutMendelssohn at Exeter Hall-Charlotte Dolby's first triumph-Willmer-Schulhoff-His private life-A romance-Rare fidelity-A cheerful prognostication - 'Mistaken treatment' - Schulhoff, Willmer and Benedict my co-performers-Henry Russell-Cheer, Boys, Cheer

\section{CHAPTER XVII.}

BRIGHTON HALF A CENTURY AGO.

First visit to London-by-the-Sea-The Brighton season in $1847-N o$ 'trippers' $-A$ fashionable AugustFrederick Wright-Jenny Lind at the Town-hallColossal receipts-Then and now-George IV.'s Pavilion-The Dome-Visit of operatic artists Frederic Beale-Music in the Square-John ParryA dearth of amusements-The Brighton Theatre- 
Mrs. H. Nye-Chart-My pianoforte recitals-News of Mendelssohn's death-Painful incident-J. W. Davison - 'Music dead '-Mrs. Sala-George Augustus Sala

\section{CHAPTER XVIII.}

$A N$ EPOCH-MAKING YEAR-1848.

Revolution-An artistic 'invasion of England '-Paris in London-Theatrical jealousy-Charles Hallé-His reputation as a classical pianist-Makes England his home-Exalted standard of taste-Phenomenal memory-His removal to Manchester-What London lost-Advantage of permanent orchestras-Manchester Royal College of Music-Hector Berlioz and the Marseillaise--Johann Strauss-His band at my concert-Weber's Concertstïck-Jetty Treffz-Reichardt -Sophy Cruvelli-I hear Chopin at Madame Sartoris'-Impressions-Poetry in sound-The Valse in D flat-Presage of Death-Mario's songs - 104-II4

CHAPTER XIX.

A LUSTRUM OF MIUSIC-1849-1854.

Henrietta Sonntag-Her reappearance-The Echo SongHer return to the stage-Mainly due to ThalbergHer death in America-A contrast-Pasta's rentréeThree compatriots-Dreyschock's concert-The effect of his piece for the left hand on one of the audience - A 'strange, courteous gentleman'- Thalberg's Florinda-A dull libretto-National concerts-Ernst Pauer-Nadame Pleyel-Wilhelmina Claus-Mrs. Anderson and Madame Puzzi-I play at the Birming. ham Festival, 1852 , and give three concerts in Vienna - My mother's death-My marriage in I854- I I5-12I

CHAPTER XX. MORE OPERATIC EVENTS-1856-1858.

Covent Garden Theatre burnt-Sympathy with Mr. GyeThe Queen's condolence-Artists staunch-Opera at 
the Lyceum--Bosio-A brief career-Mr. Lumley

at Her Majesty's-Piccolomini's début-A spoiled darling-Production of Traviata-The good offices of opposition-Times letters and pulpit referencesThe 'wicked opera' becomes the rage-Giuglini-A great tenor-Advent of Titiens-Parts in which she had no rival-Her success in oratorio-Her heroic self-sacrifice-Sings at my house in Brighton-Memorable obsequies - IVell-merited tribute -

- $122-129$

\section{CHAPTER XXI.}

\section{LISZT:}

Early memories-Visit to Vienna in ${ }_{1} \delta_{3} \delta$-An eventful charity concert - Liszt fever in the Austrian capitalA plethora of invitations-Tour in Germany-Liszt's manners-His generosity-As a benevolent concertgiver-Beethoven's statue at Bonn-Cologne Cathedral-The Munich Hospital- How it was benefitedLiszt and the inmates of the Blind Asylum-A young 'cellist-His ambitions handicapped-'Wanted, a good instrument' $-\mathrm{A}$ welcome cheque-A pianistic dilemma-Liszt's loyalty to Erard-The rival firmRemarkable tact - Illustration thereof - GrandDuchess of Saxe-Weimar-Concert at the Royal Castle - The young pianist's nerrousness - Liszt's generous self-effacement-Etiquette satisfied - I30- I 36

\section{CHAPTER XXII.}

\section{LISZT}

(CONTINEED).

A recollection of Alexander Dreyschock-His Vienna concerts in 1846 - Octave-playing extraordinaryChopin's Study-Another of the master's worksLiszt its interpreter-A sensational performanceDreyschock eclipsed-The Concordia-A brilliant banquet-The Professor's request complied withEventful result-Phenomenal improvisation-A trio of Improvisators: Mendelssohn at a Philharmonic 
concert, Stephen Heller, Ferdinand Hiller-'The last of the Mohicans '-The Prince of HohenzollernHechingen-Visited by Liszt-My wedding-tour-We stay at Weimar with Liszt-Agreeable associationsLiszt as a host-The Princess Witgenstein-The postprandial cigar-A colossal weed-Dr. Hans von Bülow - Liszt and his pupils-Visit to London in I886Soirée at the Grosvenor Gallery-Some social functions-Liszt lionized-His strength overtaxed I 37-145

\section{CHAPTER XXIII.}

\section{THE POPULAR CONCENTS.}

Production of $I l$ Trovatore in London-The cast-The Bohemian Girl à l'Italienne-Carvalho-Dinorah partly inspired by her-Her London début in L'Étoile $d u$ Nord-Meyerbeer-I meet him-His unassuming manner-The inauguration of the 'Pops'-Arthur Chappell-A pioneer of classical music in EnglandPillars of the 'Pops'-Albert Smith-A medical student-A wielder of the pen-Writes for John Parry-Becomes his rival-The Ozerland Route-Inspiration on Mont Blanc--The Egyptian Hall as a national institution

\section{CHAPTER XXIV.}

ADELINA PATTI.

'A little girl is to sing Amina'-A wonderful début-How the 'little girl' acquitted herself-Mr. Gye receives congratulations - The young diva's appearance in Brighton-Visit to Vienna-Meyerbeer's admiration -Dinorah-Flaw in a contract-Patti's rendering of Rossini's music-Her attitude towards WagnerSignor Nicolini-His likeness to Mario-Her master, Maurice Strakosch, and his double--Some curious mistakes-Stopped in Bond Street-A strange request - 'Not my sister-in-law' - A Paris incident-Tale of an umbrella . 


\section{CHAPTER XXV.}

TKEBELLI.

First heard in Prague-A true interpreter of Rossini-Introduced in London by Mr. Mapleson--From 1862 to $1890-A$ tour through England-A universal favourite - The singer's invariable good nature-A prompt understudy-Bettini-Mademoiselle Antoinette Trebelli-Her studies in Paris - Trial appearance at St. James's Hall-An audience of one-Trebelli as a raconteuse-A memorable dinner-Ineffaceable recollections-Songstress, reciter, linguist, mimic and traveller-A fascinating hostess - The daughter's début

$$
-163-167
$$

\section{CHAPTER XXVI.}

\section{' FAUTST.'}

Difficulties attending its production in England-Faust and Carmen as stop-gaps-Messrs. Chappell's rights -The price of an immortal work-A lucky 'find' for publishers and impresarios-Production at Her Majesty's - A notable cast-Doubtful receptionSubsequent crescendo of success-Mapleson's example followed-Carvalho as Marguerite - Rival casts Pauline Lucca in Huguenots - A delightful Marguerite-In L'Africaine and Fra Diavolo-German opinions--At the Court of Berlin-Prince Bismarck and Lucca - An incongruous photograph - Baron Rahlen-A devoted wife-Lucca's theatre in Austria - Musical and drannatic academy-Mario's FaustGiuglini, Jean de Reszke and Nicolini-Patti as the heroine-The Garden scene at Brighton-Christine Nilsson-An ideal Gretchen - $168-173$

\section{CHAPTER XXVII.}

$$
\text { ROSSINI. }
$$

A remarkable arrival at Kissengen-Rossini's vow against railways-Great men's fancies-Auber and ParisA true boulevardier - Walks with Rossini-His 
sarcasms-Origin of the Stabat Mater-A juvenile attempt-The master in Paris-His secretary, Louis Engel-Saturday receptions-The guests-Alboni, Taglioni, Lefort and Gustave Doré-Rossini's love of home-His 'eighteenth' birthday-PoniatowskiAn opera produced by Court influence-Rossini's counsel-An elegy on Meyerbeer-Chaos-Opinion of Tunnhäuser-A Christmas gift-The drummer's rest

\section{CHAPTER XXVIII.}

THE GARCIAS.

The Garcia-Madame Viardot Garcia, the half-sister of Malibran-A linguist-Skill with the brush-The original Fides - An aged heroine-Residence at Baden-Baden-And in Paris-A priceless manuscript Manuel Garcia, singer and teacher-Jenny Lind's master-Professor at the R.A.M.--The Grand Old Man of music-His ninetieth birthday-Unfailing courtesy

\section{CHAPTER XXIX.}

CHRISTINE NILSSON.

A regrettable performance-Fall of a public idol-And rise of a new 'star'-Début of Nilsson in $\mathrm{s} 867-\mathrm{A}$ beautiful Traviata - My companion's infatuation Nilsson at my concert--The Mad scene from Lucia -A highly dramatic achievement--Some French rôles -And Swedish melodies-Happy suggestion-The diva's English farewell-Handsome emoluments-A pleasant supper in Brook Street-Sims Reeves again -The singer's pledge-Its fulfilment-Letter from Grange Mount-Another from Nilsson - - I90-198

CHAPTER XXX.

MARIO.

Farewell performances in $1871-A$ memorable seriesThe great tenor in La Favorita-A moving scene- 
Mario in private life-Pretty compliments to a little girl-The calumet of peace-Statesman and artistMario, the friend of Cavour - Some facts about artists' salaries - Generosity of Mario-'The waiter in luck-Itinerant musicians rewarded-Recognition from 'Sir Hubert'-A well-deserved testimonialKindness of Sims Reeves - Mario befriended by Victor Emmanuel - All roads lead to RomeWilliam Cusins-Queen Victoria's tribute to a great singer

- $199-204$

CHAPTER XXXI.

EMMA ALBANI.

Paris and the war of 1870-Marimon-Marie RozeCampanini - Two notable exponents of Bizet-The musical event of i 872-A new Amina-Albani's début-A golden night at Covent Garden-A conscientious student--Catholicity of taste--The diva's Desdemona-Success in oratorio - The Golden Legend -A great festival singer-Alarming incident at a benefit performance-The prima donna injured'All's well'

- $205-210$

\section{CHAPTER XXXII.}

ANTON RUBINSTEIN.

His magic touch-Liszt's first receptions dimmed by Thalberg-England ripe for Rubinstein-Oftener heard than Liszt-First recitals at Hanover Square Rooms in $185^{2}$ - Twenty-four years later at St. James's Hall-Ovations-Historical recitals in Paris - Free admissions to students-Repeated in London, I 886-Charity concert - Generosity-Compositions not yet fully appreciated-Rubinstein's private lifeEnnobled by the Czar-Dislike of ceremony-Hatred of solitude-Fondness for cards - Musicafter dinnerHis friend Dr. Max Schlesinger--Rubinstein's superstitions-Dilemna at Edinburgh-Another poor musician-The difficulty solved-His pithy repliesLikeness to Mr. Bradlaugh - 


\section{CHAPTER XXXIII.}

\section{PIANISTS.}

Sophie Menter-Her father-The pianist's post at St.

Petersburg-Her pupil Sapellnikoff-A feline companion-A mysterious hamper-Pussy in the artists' room-Madame Essipoff-Leschetizky-Paderewski's professor-Hans von Bülow-A splendid conductor - Anecdotes of his wit-The circus band insulted'Court pianist to the German people'-Vladimir de Pachmann-An unrivalled exponent of Chopin 222-229

\section{CHAPTER XXXIV.}

\section{PIANISTS}

(CONTINUED).

The mantle of Rubinstein - Sympathy between artist and audience-Paderewski's conscientiousness-Assiduous practice at night-His facile memory--Never repeats himself-Compositions-Powers apart from music-Recreations - Billiards-Croquet - Superstitions - His walking-stick-Anecdote-Lucky crossingsweepers - A plain-spoken boy - Saint-Saëns Qualities, artistic and personal-A perfect organistHis improvisations-Instance of facility-Josef Hofmann-His musical organization-Engaging qualities -Illness in America-Rubinstein as a prophet-Hofmann visits us in Brighton-His talent for drawingCassell's pictures-Stavenhagen-A pupil of LisztSauer-Rosenthal-Reisenauer - - $230-238$

\section{CHAPTER XXXV.}

SOME VIOLINISTS OF CELEBRITY.

Prume-La Melancolia-A one-horse composer-Violinists in London, 1845 - 'The mighty Vieuxtemps'-Admiration for Spohr-Jessonda and The Power of SoundA Norwegian fiddler-Ole Bull in Germany-Player and philanthropist-Mr. Henry Jarrett-Carl Formes -New reading of the Kreutzer Sonata-I hear Ernst in 
I 839--His subsequent visit to England-The violinist befriended by Lord Lytton-Paganini's pupil, Sivori - No impostor'-A non-classical executant-His economic propensities-Too late for the train-Walking a luxury-Molique at Stuttgart-His pupil, J. T. Carrodus-Prosper Sainton and his gifted wifeMendelssohn impressed-Royal Academy of Music - The principal's choice of a successor-Emil Sauret

$$
\text { - } 239-245
$$

\section{CHAPTER XXXVI.} ARTHUR SULLIVAN.

An appreciation-The gaiety of the nation-The Mikado in Germany-How it impressed my young friend $246-25^{\circ}$

\section{CHAPTER XXXVII.}

COMPOSERS AND ORCHESTRAL CONDUCTORS.

The importunate interviewer-'Story, sir, I have none to tell '-Fantastic farrago-Julius Benedict at the desk - Mendelssohn at the Philharmonic concerts in 1847 - The Hymn of Praise-Michael Costa and some of his successors-Balfe - Sterndale Bennett-IVilliam Cusins-Master of the Queen's Music-F. H. Cowen -As a boy composer-Bright promise fulfilled-The Scandinavian Symphony-A composer with lofty aims - Cowen in the Antipodes-Sir Alexander Mackenzie - Richard Wagner and the Philharmonic concertsSir A. Sullivan as conductor-Edvard Grieg-A meeting with Dvoràk-The Spectre's Bride - $25 \mathrm{I}-258$

\section{CHAPTER XXXVIII.}

OTHER ENGLISH COMPOSERS.

Arthur Goring Thomas-A favourite song of Lloyd'sC. H. Hubert Parry-The 'English Bach'-C. Villiers Stanford-J. F. Bridge-His Purcell researchesA. C. Mackenzie-A Y iszt 'subject'-F. H. CorderTranslations of IVagner-Edward German-English music in the Fatherland

$$
\text { - } 259-263
$$




\section{CHAPTER XXXIX.}

AUGUST MANNS.

Music at the Crystal Palace-A peep into the past-.

Opportunities formerly enjoyed by amateurs-What the Palace conductor did for them-Few orchestral concerts in London-Pilgrims to Sydenham-The musicians' Mecca-Old masters and young menThe Sydenham institution as a stepping-stone-Mr. Manns and rising artists--Scotch music-Learmont Drysdale-Mr. Manns and the Scottish OrchestraThe conductor's seventieth birthday - A notable gathering-Honours refused-Another pillar of the Palace-Sir George Grove-A friend in need-Two musicians in Vienna-Interesting researches-Musical treasure-trove-The Dictionary of Music - 264-273

CHAPTER XL.

A BATCH OF CONDUCTORS.

Otto Goldschmidt and the Bach Choir-Jenny Iind and the chorus-Mr. Henschel's Symphony ConcertsSir Joseph Barnby-The Royal Choral Society--An eclectic musician - Expert opinion on music-hall ditties - Guildhall School of Music - Dr. Henry Wylde-The 'New' Philharmonic Society in $185^{2-}$ Wilhelm Ganz-Hector Berlioz-His Romeo and Juliet symphony-Lindpeintner and Spohr-Hans Richter-Other German conductors-Wagner's music in England-Concerts without 'star' singers-The conductor's apotheosis-Richter's memory-Score of Die Meistersinger - The doctor at rehearsals - $274-280$

\section{CHAPTER XLI.}

THREE ENTERTAINERS.

John Wilson-A thorough artist-Two boon companions - Corney Grain as a law student--The Old Bailey renounced-Theatrical wig and gown-The author in 
Corney Grain's robes-My' visit to a lunatic asylum-

A strange 'partner'-Astonishing recognition-The entertainer's manner and methods-The idol of the ' unco guid'-A peep at Tunbridge Wells-'Abandon hope . . .-Pink Dominoes whitewashed-Goodnatured chaff-George Grossmith-A modern Theodore Hook-A cause celébre-The season 'crush'How Gee-Gee spoofed the guests-A welcome cable - A letter from Corney Grain - $\quad-28 \mathrm{I}-29 \mathrm{I}$

\section{CHAPTER XLII.}

MR. J. II. LEVY.

My early struggles-The friend of young artists-The Sunday Times-An artistic symposium-The Daily' Telegraph-Predictions falsified-The first penny daily paper-Florence Cottage-An art connoisseur - Musical and theatrical celebrities - The actors' counsellor - Hints to managers - Social entertainments in Grosvenor Street - A memorable duologueReturn of the wanderer-The great actor's first call -A dinner to Henry Irving-Sir Julius BenedictReminiscences lost to the world-Mr. Lionel Lawson -The Queen's, in Long Acre-The Gaiety-Sir Edward Lawson-Criticisms in the Daily TelegraphSome contributors thereto - $\quad-\quad-292-301$

\section{CHAPTER XLIII.}

MUSICAL ASPIRANTS.

An incurable malady-Young talent-Importunate friends of beginners-'So and So's'-_Trials and tribulations of impresarios-Myopinion sought under curious circumstances - The strange gentleman - An extraordinary request-A comic version of the Erl KingCommon form of insanity-The other side of the picture-Two successful débutantes-Miss Margaret Macintyre 


\section{CHAPTER XLIV. \\ OUK OPERATIC MANAGERS.}

Benjamin Lumley-Opera in I 845 -Some famous dancers -'Taglioni and the swaying sisterhood-Lumley and his competitors-Deserted by his singers-Loyal Lablache-The manager unbaffled-A rival flourish of trumpets-The Covent Garden Syndicate-Jenny Lind to the rescue-Rentrie of Sonntag-Titiens and Piccolomini - Frederic Gye's enterprise - English opera at Drury Lane-The 'poet Bunn'-Mr. Punch in trouble-Harrison the tenor-Louisa PyneLikeness to Queen Victoria-Gye's 'stars'-In the ascendant-My relations with the manager-Concert at the Floral Hall - Italian opera at the National Theatre-E. T. Smith and Mapleson-'The latter beloved by artists-Array of talent-Signor LagoGayarré-The sisters Ravogli-'Young Italy' at the Shaftesbury Theatre-Cavalleria RusticanaA Russian opera - Eugene Oudin - Mr. D'Oyly Carte and the Royal English Opera-Sullivan's Iíanhoe

\section{CHAPTER XLV.}

SIK AUGUSTUS HARRIS.

Temporary decline and fall of grand opera-London a lyric wilderness-Sir Augustus to the rescue-An organizing genius-A globe-trotting manager-Early attempts at revival-Initial difficulties-A plea for a Government subsidy-Renascence of Italian operaNative talent encouraged-Three simultaneous performances - Public recognition - A testimonial Generous gift to academies-Ceremony at Drury Lane-A significant promise- 'National opera' in London - Subventions abroad - Court Theatre in Vienna-The Emperor William and the Berlin opera -Superstitions of an impresario-Peacocks' feathers 
on the drop curtain - The prima donna's birthdaycard-Visit from a coryphée-The dreaded plumes again -

\section{CHAPTER XLVI.}

OPERATIC CONDUCTORS.

Signor Arditi-Cavalleria Rusticana in London-Il Bacio -An interpolation in II Barbiere-Hänsel and Gretel -Operatic morning concerts-Conductors in demand-Bevignani and Vianesi-Mapleson's perspicacity-Alberto Randegger-Carl Rosa as conductorVisit to the United States - 'Love at first-sight'Madame Parepa-Courtship on the steamer-Beginnings of the Carl Rosa opera - English opera a success-Popularization of good works-Carl Rosa in Paris-Fatal visit-The influence of personalityRevived fortunes

\section{CHAPTER XLVII.}

BRIGHTON ORCHESTRAL CONCERTS.

The Orchestral Union-Frederick Kingsbury-J. T. Carrodus as leader-Some well-known instrumentalistsMademoiselle Liebhart-The Brighton Concert Hall - Panoramas z'ersus Polyphony-A small orchestraCharacter of the programmes-Financial failureSeats at sixteenpence-Mrs. Stirling as a reciter-Midsummer Night's Dream-Samuel Brandram-The Brighton Dome-An increased orchestra-Madame Lemmens Sherrington-Anna Thillon-Madame Schumann and some noted executants-Falling off in receipts-Musical feast-Cowen's Symphony in $C$ minor-A boy composer-Brighton Sacred Harmonic Society-Mr. Robert Taylor-'Monday Pops' at Brighton-Lilliputian takings-A first and last attempt-Roseate view of the future - $\quad 334-34^{2}$ 


\section{CHAPTER XLVIII.}

THE BRIGHTON MUSICAL FESTIVALS.

First of the series--Works by English composers-F. H. PAGE Cowen's Maid of Orleans-Crounod in BrightonFirst visit of Edward Lloyd-Miss Virginia GabrielBenedict's Tale of Fairyland-W. Sterndale Bennett - His dislike to public appearances-His last Letter from the composer-Sir George MacfarrenJ. F. Barnett and G. A. Osborne-La Pluie des Perles -F. Clay's Lalla Rookh-The composer at workSons of Araby_Madame Sainton Dolby-A Deluge - And another-A disciple of Sullivan's - Alfred Cellier-Walter Macfarren-His first pupil-My nerves give way-Some interesting novelties-After eleven years-A few reflections-Final attemptMeeting of 1882-An Elijah cast-The Redemption - Testimonial from my subscribers-Disastrous losses - Unfulfilled pledges-A painful subject-A word about other English festivals - Why I renounced mine - $343-35^{6}$

\section{CHAPTER XLIX.}

\section{PAST AND PRESENT-I845 AND 1895.}

'Were the English a musical nation?'-A question never asked-Latter-day improvements-The old music-hall argument-Metropolitan concert-rooms in 1845Hanover Square-Willis's Rooms-Exeter Hall-Its danger in case of fire-The hall attached to Her Majesty's-Stipulations of the directorate-Sir Julius Benedict's concerts-The dearth of music in the winter season-Concerts given by professors of inusic -A convenient educational process-Entertainments at private houses-Matineés musicales and 'at homes' -A quid pro quo-Signor Marras and J. Blumenthal - 'Benefit' concerts - The limited répertoires of artists 


\section{CHAPTER I.}

\section{PAST AND PRESENT-I845 AND 1895}

(CONTINUED).

Apathetic audiences and loquacious listeners-Talking during performances-What it enabled me to do-A party in Belgrave Square and my practical joke-The accommodation of old concert-halls-The Brighton Town Hall-Singers' salaries in the forties-A Mario and Patti concert-Albert Hall concerts and a diva's terms-Sims Reeves then and now-Printing and advertising-- Public ideas as to the cost of concertgiving-Peculiar impressions-An income-tax storyThe writer as a millionaire-Why the Commissioners imagined him to be one

$-365-372$

\section{CHAPTER LI.}

\section{PAST AND PRESENT-I845 AND 1895}

(CONCLUDED).

Programmes at miscellaneous concerts in the past-Days of trash-The taste of audiences half a century ago -An artists' room anecdote-Programmes of Gargantuan length-My own failings in this directionSt. James's Hall-An early Philharmonic concertA performance at Her Majesty's in ' $5 \mathrm{I}$-A Covent Garden bill-Present-day operatic representationsA modern German fashion-A story about Cazalleria Rusticana-An uncanny Scot-English singers of today-Miss Maude Valerie White's compositionsAmateur orchestras-A sign of musical progressThe Duke of Edinburgh as 'first violin'-Musical education in this country-Then and now-The R.A.M.-Royal College of Music-Guildhall School of Music--Provincial musical institutions-Brighton School of Music 


\section{CHAPTER LII.}

MY SEVENTIETH BIRTHDAY AND MUSICAL JUBILEE.

Congratulations on December ro, '93-Loyal friends in and out of the profession-Letter from Sir Arthur Sullivan-My birthday-party-The testimonial-My Brighton friends-Ceremony at the Royal PavilionMy jubilee concert in London-Committee and artists

-An apology

- $380-385$

INDEX

$-387$ 
LIST OF ILLUSTRATIONS AND FACSIMILE AUTOGRAPHS.

Portrait of the AUthok, PRODUCED froN a Photograph by Donovan, Brighton Frontispiece Facsimile Autographs :

\begin{tabular}{|c|c|c|c|c|c|c|c|}
\hline THALBER & & - & - & - & - & face $p$. & 25 \\
\hline VERDI & - & - & - & - & - & , & 124 \\
\hline IIEYERBE & EER & - & - & - & - & ", & I 47 \\
\hline PATTI & - & - & - & - & - & ", & 162 \\
\hline GOUNOD & - & - & - & - & - & $n$ & I 73 \\
\hline ROSSINI & - & - & - & - & - & ", & I 83 \\
\hline SIMS REE & EVES & - & - & - & - & , & I 97 \\
\hline CHRISTIN & NE NILSS & SON & - & - & - & ", & 198 \\
\hline MARIO & - & - & - & - & - & ., & 204 \\
\hline GRISI & - & - & - & - & - & $"$ & 204 \\
\hline ALBANI & - & - & - & - & - & $"$ & 210 \\
\hline RUBINSTI & EIN & - & - & - & - & $"$ & $22 \mathrm{I}$ \\
\hline PADEREW & VSKI & - & - & - & - & " & 234 \\
\hline CORNEY & GRAIN & - & - & - & - & $"$ & 291 \\
\hline STERNDA & LE BEN & NETT & - & - & - & ", & 347 \\
\hline SIR ARTI & HUR SUl & LLIVAN & - & - & - & " & $3^{8 r}$ \\
\hline
\end{tabular}





\section{MY MUSICAL RECOLLECTIONS}

\section{CHAPTER I.}

\section{PRAGUE.}

Early years in Prague-My parents and brother-Bridge over the Moldau-Edinburgh and Prague: a comparisonCharles X. in exile-The daughter of Marie AntoinetteEmperor Ferdinand crowned King of Bohemia-Gala performance at the Opera House-Meyerbeer's Il Crociato - Lavish expenditure-Madame Schröder-Devrient-A German Mrs. Keeley.

Mr early years, about which I propose saying as little as possible, were passed in Prague, where I was born on December 10, I 82.3. It cannot be said with strict accuracy that I came of a musical family, for although my father had a passion for music, he had left his aptitude for it entirely without cultivation. My mother, on the contrary, sang and played with a facility and excellence quite unusual among amateurs, and the elder of my two brothers entered the ranks of the musical profession, which he followed in Kieff (Russia) till his death, in 1893 . 
I do not suppose that the details of my childhood will possess the slightest interest for the ordinary reader, yet I can hardly forbear a reminiscence of my early morning walks across the bridge which spans the Moldau on my way from the Altstadt (old town), where my father resided, to the house of my master, Tomaschek, in the Kleinseite, another quarter of this picturesque oldworld city. How beautiful the bridge seemed to me in the first hours of a clear frosty day in winter, when its magnificent niches and statues of patron saints stood out clear and bright against the crisp morning air, while all around me soared those clustering spires of minarets which so irresistibly suggest Constantinople! Nothing recalls to me so vividly the peculiar beauties of my native city as stately Edinburgh, whose castle overtops the streets in precisely the same manner as the Alte Schloss of Prague dominates its ancient thoroughfares. In Prague, of course, the river takes the place of the great, though happily concealed, railway cutting which permeates Modern Athens.

One incident, at least, occurs to me which will bear recording. I remember well, at the age of eight or nine, the arrival of the exiled King of France, Charles X., and his family, the Emperor Francis of Austria having placed at the disposal 
of the dethroned monarch the magnificent imperial castle on the Hradschin, a building famous alike for its historical associations and noble architecture, and almost unrivalled in its command of a view entrancing beyond expression. With the King was an elderly lady who appeared to be the object of exceeding deference. I recall, as though he spoke but a day or two since, the remark of my tutor as he pointed her out to me, with the words, 'You see that lady in black. Her father was King and her mother Queen of France; and they were both cruelly beheaded by the revolutionary mob in Paris.' The lady was the Duchesse d'Angoulême, generally known as ' Figlia Dolorosa.'

Not many months later the Emperor Francis died, and was succeeded by his son Ferdinand, crowned, as I well remember, King of Bohemia in our own city. Great was the excitement in Prague during that eventful fortnight of festivity. People flocked into the town from every part of Bohemia, and were glad to secure lodgings at any price. Reviews, fireworks, torchlight processions and theatrical performances were the order of the day as far as the general public was concerned. These were supplemented for the nobility by state balls and concerts at Court.

A mong the musical artists who took part in these 
celebrations was Madame Schröder-Devrient, who came from Dresden, where she was permanently engaged. This lady, who was certainly one of the finest singers the world has ever known, I heard in the part of Fidelio, in which both her acting and singing were superb-in fact, unequalled, the only other artist who approached her in Beethoven's solitary opera being Titiens, whom I saw in the same part many years afterwards in London. The opera chosen for the Court performance at the Theatre was Meyerbeer's Il Crociato, an early work by the composer of the Huguenots, and a very weak one, although it lends itself admirably to spectacular effects. The expenses incurred by the gorgeous dresses, the glittering armour, and the elaborate scenery, were simply enormous. Yet it was thought necessary to add to them still further by ordering a new drop-scene, on which was painted a realistic representation of the old bridge referred to above, and that part of the city which includes the Imperial Castle. The cost of this item alone reached something like $\mathrm{I} 0,000$ florins $(£ \mathrm{I}, 000)$. Schröder-Devrient* took the leading part in the

* Madame Schröder-Devrient was the daughter of Madame Schröder, the German Mrs. Siddons, who passed the last years of her life in Augsburg. I have, of course, never seen her on 
opera. Altogether it was a time full of memories yet undimmed. I may add that it was the last occasion on which a coronation took place in Prague, for the present Emperor, Francis Joseph of Austria, was never crowned King of Bohemia.

the stage, as she had retired from public life for many years when I made her acquaintance in Augsburg in 1844 . She was then a very old lady, but full of spirit and energy, like Mrs. Keeley of our day; and she did me the great kindness to give a recitation at one of my concerts. 


\section{CHAPTER II. \\ A LINK WITH THE PAST.}

An artistic rendezvous-Swoboda-Production of Don Giovanni at Prague-Status of Prague as a musical centre-Its orchestra and Conservatoire-Weber Kapellmeister - Mozart at Prague - His estimation of it musically-Rehearsing Don Giovanni-His words of approbation-Zerlina's scream-Original finale of the opera-Jubilee celebration at Prague-The first PaminaMozart's son-Cardinal Prince Schwarzenberg-Cardinal Prince Hohenlohe.

My father's house was the centre of artistic life in Prague. Under its roof, week by week, met actors, singers, and orchestral players. Chief among the latter I remember a tall, gaunt, elderly man, by name Wenzel Swoboda, a performer on the double bass at the Opera House. He had been a member of the orchestra on the occasion of the production (October 29, I787) of Don Giovanni, which was specially written by Mozart for the Prague Opera House, the master coming 
from Vienna to finish his work and conduct its first performance.

Bohemia has always been wonderfully musical. Every peasant, although untaught, plays some instrument, the ensemble performances of the country villagers being often quite marvellous. Prague used to rank as the most musical city in Germany. Vienna, I believe, now holds the first place, Leipsic coming next. But until i $\delta_{3} 0$ the orchestra of Prague was considered the best in the country, and many famous men in turn conducted it, among them being Carl Maria von Weber, who was its director from I $\delta$ I 3 to i $\delta$ I 6 . During many long years composers, singers, and instrumentalists came to Prague to win their spurs, and the leading members of the chief German orchestras made a point of studying in its Conservatoire.

The conceit (as I may term it) of the good people of my native city was increased a hundredfold when Mozart, in a speech delivered at a banquet in his honour, declared (so Swoboda told me) that the citizens of Prague were the only people in the world who understood his music. Had he lived longer he might have modified this opinion. Speaking of Mozart, I am reminded that my friend Swoboda used also to refer to the 
pleasure evinced daily by the great master in the game of billiards. He would also from time to time recall Mozart's habit of laying aside mere speech in favour of musical recitative, which even in public he would use as a means of making remarks and conveying requests to his circle of friends. From the same authority I learned the positive truth of the story (often told and as frequently denied) that on the night before its production the overture to Don Giovanni had not even been sketched. The impresario, said Swoboda, was in despair. Mozart's wife, however. undertook that the overture should be finished in time. She accordingly sat up all night with her husband, although she found it difficult to keep him awake. As he wrote, the sheets of the score were passed from his desk to those of a little army of copyists who were in attendance to transcribe the instrumental parts. Again and again was the great maestro overpowered by sleep, and every time he was aroused by his vigilant helpmate he broke into song as follows :

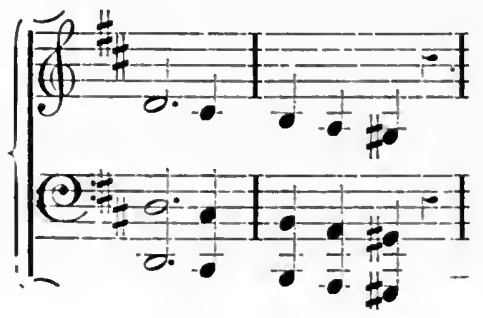


These two bars continually recurred to him, and were as often written down.

The ink, Swoboda recalled, was hardly dry on some of the pages when they were placed on the desks of the orchestra. A rehearsal was impossible. Nevertheless, the overture was played with a spirit which not only roused the enthusiasm of the audience to the highest pitch, but so greatly delighted the illustrious composer that, turning to the orchestra, he exclaimed, 'Bravo, bravo, Meine Herren, das war ausgezeichnet!' (Bravo, bravo, gentlemen, that was admirable!).

At the end of that memorable first night Mozart declared that such a performance at sight was an extraordinary feat, 'obschon manche Noten unter die Putte gefallen sind' (although several notes had tumbled under the desks).

And now another of Swoboda's reminiscences :

At the final rehearsal of the opera Mozart was not at all satisfied with the efforts of a young and very pretty girl, the possessor of a voice of greater purity than power, to whom the part of Zerlina had been allotted. The reader will remember that Zerlina, frightened at Don Giovanni's too pronounced love-making, cries for assistance behind the scenes. In spite of continued repetitions, Mozart was unable to infuse sufficient force into 
the poor girl's screams, until at last, losing all patience, he clambered from the conductor's desk on to the boards. At that period neither gas nor electric light lent facility to stage mechanism. A few tallow candles dimly glimmered among the desks of the musicians, but over the stage and the rest of the house almost utter darkness reigned. Mozart's sudden appearance on the stage was therefore not noticed, much less suspected, by poor Zerlina, who at the moment when she ought to have uttered the cry received from the composer a sharp pinch on the arm, emitting, in consequence, a shriek which caused him to exclaim : 'Admirable! Mind you scream like that tonight!'

The opera, as at first written, did not terminate with the carrying off of Don Giovanni by the Furies. This episode was followed by four additional numbers, including a quartette by Donna Anna, Elvira, Zerlina, and Ottalio. After the first night, however, these pieces remained unheard until the jubilee performance of the opera at Prague in $18_{37}$, on which occasion I was present. They were then voted exceedingly dull, but it must be confessed that the whole representation was distinctly second-rate in the absence of several of the principal vocalists, who were down with la 
grippe. At the century performance, fifty years later, my brother travelled from Kieff to Prague on purpose to be present, my own intention of meeting him being frustrated by professional duties at home.

My friend Swoboda would sometimes refer to the consternation excited in Prague by the news of Mozart's death, in December, I791, and would dwell on the solemnity of the Requiem Mass in the great church of St. Nicholas (now disused), to which thousands vainly sought to gain admission.

To these reminiscences of one who knew Mozart in the flesh, I may not unfitly add some personal recollections of my own which have a distinct connection with his memory. The inauguration of his monument in Salzburg, his native city, was celebrated in 1842 by a great musical festival, at which it was my privilege to be present.

At that time there were only two hotels in the city, the Ship and the Archduke Charles. The festival committee, however, undertook to find accommodation for thousands of music-lovers who flocked to Salzburg for the occasion. After one of the meetings, to which my old friend Herr von Hildebrand had introduced me, a servant announced the arrival of an old lady who would not be denied admission, saying that she had a most 
important communication to make. Permission having been granted, there entered a very tall, thin and eccentric-looking woman, who at once exclaimed, as though addressing an audience: 'Ich bin die erste Pamina'* (I am the first Pamina). Naturally we thought her demented, but investigation established the truth of her assertion. This lady, whose name was Madame Gottlieb, had ostensibly come from Vienna to join in our homage to Mozart ; but as a matter of fact she seemed to think that she had at least an equal claim with him to be an object of universal veneration. Not satisfied with the generous hospitality extended to her, she expected deputations to wait upon her, and other extreme marks of attention.

During the Salzburg festivities I made the acquaintance of Mozart's second son, who bore his father's Christian names, Wolfgang Amadeus. I found him a very modest, unassuming man, requiring much persuasion, on one occasion, before he could be induced to play his father's magnificent Concerlo in $D$, which he did in a masterly manner. He died at Carlsbad in 1844 , and would have achieved undoubted celebrity but for the

* Pamina is the name of the heroine in Il Flauto Magico, and Madame Gottlieb was the representative of that character at the first performance at Vienna, in $179 \mathrm{r}$. 
overshadowing influence of his father's fame. I also visited Mozart's sister-in-law, who lived in the house where the composer first saw the light.

Among other notable acquaintances made during a twelvemonth's residence in the neighbourhood of Salzburg, I must mention Cardinal Prince Schwarzenberg, afterwards Archbishop of my native city. Belonging to one of the oldest noble families of Austria, he was exceedingly handsome, young for his great position, and possessed of exceeding charm of manner. He was an excellent performer on the pianoforte, and I often joined him in a quatre mains.

By the way, another dignitary of the Church, now resident in Rome, Cardinal Prince Hohenlohe, is a fine musician and excellent pianist. For thirty years he was the intimate friend of Liszt, who frequently played pianoforte duets with him.

In Salzburg I was made an honorary member of a society called Der Dome Music Verein und Mozarteum. The distinction, a much-coveted one, was considered a great honour for a musician who had not yet attained his twenty-first year. 


\section{CHAPTER III.}

\section{PAGANINI.}

My childish impressions of the violinist-A melody he played -Musical 'prodigies '-Paganini's miserly propensitiesThe laundress's bill - The violinist as a wit-Rebuke to his hostess - His kindness to Berlioz.

Mr earliest musical experience was obtained at the age of five, when I was taken by my mother to a concert to hear Paganini. That first and very juvenile experience left an indelible impression upon my musical ear in this sense, that there was in what the master played one scrap of melody which so implanted itself in my memory that, coming home, I contrived to pick it out, more or less accurately, on the piano. Even at this date the air recurs to me, and it may be deemed worth while to indicate it. It opened thus :

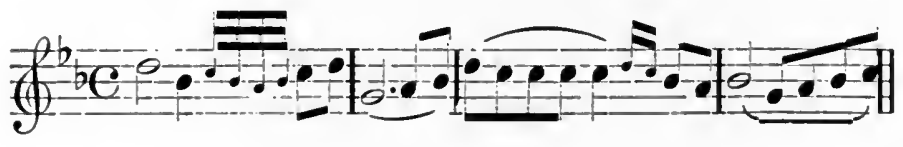


Strangely enough, the incident above recorded was sufficient to delude my good parents into the belief that unto them had been born an infant prodigy, and in a rash moment they determined to make me learn the piano. I may here remark that in those days, fortunately for children happy in their nursery and on the playground, the 'prodigy' craze was undeveloped. The days when it became quite a novel experience to see a person of mature years walk on to a concert platform and manipulate the keyboard were still to come.

But to return to Paganini. He caused a greater sensation than any instrumentalist of the century until Franz Liszt came to take the world by storm. Many were the stories I heard of his miserly life and extraordinary stinginess. One of these is worth recording. His laundress, who had never heard him perform in public, was extremely anxious to be present at a concert he was announced to give. High-priced seats were not for her, and it so happened that all the gallery tickets had been disposed of. Great, therefore, was the delight of the worthy blanchisseuse when the renowned fiddler wrote her an order for the topmost tier, and loudly did she proclaim his good nature 'below stairs.' Conceive, then, the 
good woman's astonishment when, on presenting her account at the end of the following week, she was requested to deduct an amount equivalent to the value of the gallery ticket which her employer had given her.

Paganini, I was told, was in the habit, when engaged in conversation, of giving very laconic answers to questions asked, but they were invariably to the point. A lady occupying a considerable position in the social world invited him to a dinner-party, to which men and women distinguished in art and literature were bidden. Rightly or wrongly, she expected that he would consent to play something during the evening. But she reckoned without her guest. When the great man arrived, she discovered that he had not brought his instrument.

'Oh, Signor Paganini!' she exclaimed reproachfully, 'you have not brought your violin.'

'No, Lady —-, was the witty answer; 'my violin never dines out.'

Having spoken of the artist's meanness, however, it is but fair that I should chronicle one incident in illustration of the better side of his nature. When, as quite a young man, Berlioz, the composer, found himself in Paris in very straitened circumstances, he wrote an orchestral 
work (Symphony Fantastique) of great power and charm. Paganini, then in Paris, happened to hear it, and also became possessed of the knowledge of the composer's poverty, whereupon he at once made him a present of a considerable sum of money-as much, indeed, as 20,000 francs (£800). 


\section{CHAPTER IV.}

\section{EARLY MUSICAL MEMORIES.}

My first lessons in music-Joseph Proksch's school-Wenzel Tomaschek-Holidays in Vienna-Hummel's and Moscheles' concerts in Prague-A droll appearance-King Louis of Bavaria-Mrs. Moscheles and her daughterKalkbrenner and his son-The Revolution of 1848 Kalkbrenner's appearance and style of dress-His conceit -A duet with his son-An evening party-Chopin and Kalkbrenner-Thalberg-What he did for piano-playing - His Don Giovanni fantasia-The composer's bon mot$\mathrm{His}$ appearance at my Brighton concert.

In a previous chapter I have explained how the fact of my being able to pick out with one finger the melody I had heard played by Paganini induced my parents to make me learn the piano. It is not for me to question the wisdom of that step. I recollect, in one of his inimitable sketches, that my friend Mr. George Grossmith makes much comic capital out of a call he paid to a certain lady whose last-born was possessed of such precocious 
gifts that she wanted her visitor to hear him play the whole of the Mikado with one finger on the piano. That lady was well-intentioned, but misguided. Possibly so were my parents. Having apologized for this digression, let me hasten to say that, notwithstanding my musical memory at the tender age of five, it was not till I was seven that I first began to take lessons. But at that time, needless to say, I was not intended for the musical profession, and even three years later, when I was sent to college, my people had formed no definite plan with regard to my education.

In I 833, however, Joseph Proksch, a name familiar to a bygone generation, and who was an intimate friend of my father's, opened a school of music, and I became his first pupil. Poor fellow! he was sightless, but although thus afflicted, he was at all times wonderfully cheerful, and I once heard him laughingly remark that deafness would have suited him much better, as he would then have been spared the torture of hearing so many wrong notes. I remained at college and at the Professor's school, which soon became famous, until I 836 , when I firmly resolved, with my father's consent, to make music my serious study. On leaving college four years later I was placed under Wenzel Tomaschek, who had some years previously been my elder 
brother's Professor, and who continued to teach me until $r$ 843. At this time my father was in the habit of taking me annually to Vienna (except in 1842 , when I attended the Mozart Festival in Salzburg). My Vienna holidays afforded me the opportunity of becoming personally acquainted with many artistic celebrities. The three rival pianoforte virtuosi at an earlier period were Hummel, Moscheles, and Kalkbrenner.

I remember being at a concert given by the first named in Prague. He was then close on sixty years of age, had renounced playing in public, and devoted himself almost wholly to composition and teaching. Both as composer and teacher he excelled. He wrote in quite a classic form, and probably as a Professor he had never been surpassed, while in his beaux jours his playing was considered matchless. I cannot, of course, say what it was induced him to leave Weimar and come to Prague, on the occasion in question, to give a concert. It proved a mistake, his performance merely resulting in a succès d'estime. His style struck those who then heard him as old-fashioned, but he created a very favourable impression as an improviser. Hummel died in the following year.

I recollect Moscheles visiting Prague (his native city) in 1840 to see his aged mother and other 
relatives. He was prevailed upon to give a concert, the proceeds of which were distributed among several charitable institutions. I can call to mind the audience being delighted with his almost youthful, vigorous, and really fine execution, albeit they were familiar with the performances of other great representatives of the modern school of pianoforte-playing, such as Liszt and Thalberg.

At this concert Moscheles played his Concerto Pastorale, several of his unrivalled studies, and concluded with an improvisation. I ought to mention a peculiarity about his first appearance on the platform which amused the audience vastly. The concert took place in the theatre, and when, the overture concluded, he stepped on to the stage, he carried in one hand his hat and in the other his stick, for all the world like a lion-comique of the present day. After looking around him for a convenient corner in which to deposit his impedimenta, he finally, amidst much hilarity, discovered a chair, on which he proceeded to place them before taking his seat at the piano-stool.

I heard Moscheles again in 1844 at Munich, when, to an already very exhausting programme, he added, at the express desire of King Louis of Bavaria, who was present, his famous variations on the Alexander March. I may add that when 
in the following year I came to London, the very first visit I paid was to my friend Moscheles and his family. His wife and eldest daughter, both charming ladies, had been with him in Munich, where I made their acquaintance.

Although strictly not in place, I should here allude to my impressions concerning the third of the virtuosi named-Kalkbrenner. I had never expected to hear him, as in my time he had long given up public playing, being highly successful as a teacher, and being, moreover, a partner in the pianoforte-making firm of Pleyel, in which he realized a considerable fortune. My hearing him was brought about in this way.

In 1848 the Revolution in Faris drove many artists from the French capital to London. Kalk. brenner was amongst the number. I chanced to be at an evening party to which he and his son were invited. The former was a strikingly handsome old gentleman. He wore a bluish dress-coat with large gilt buttons, and reminded me of a typical beau seigneur of France. Very different was the appearance of his son, who was dressed up to the eyes, and would in later years have deserved the designation of 'masher.' Father and son played a manuscript sonata à quatre mains, but I cannot pretend to have been greatly struck 
either by the work itself or the interpretation thereof. When the performance was over, the hostess (Madame Dulcken), walking up to the piano, thanked Kalkbrenner in a few gracious words, whereupon the virtuoso, who was nothing if not conceited, ejaculated:

'That is the kind of music that I love.'

The lady might, of course, have given expression to the 'retort polite,' but, instead of doing this, she gracefully remarked:

'Yes, and you have the genius to compose, and the skill to execute, such music.'

Apropos of Kalkbrenner's extraordinary vanity, about which I had previously heard a good deal, I may mention one little anecdote. Chopin, when a young man, called upon the composer-pianist and played to him. Having heard the master, Kalkbrenner said :

'You certainly have a good deal of talent, but you ought to have lessons from me to learn proper fingering and technique.'

It was, I believe, in $8_{3} 7$ that I heard Thalberg for the first time. His exquisite touch, unfailing accuracy, and perfect phrasing, made a great impression upon me. Thalberg created quite a new school of pianoforte-playing. When listening to him for the first time, it seemed to me almost 
incredible that two hands should be able to produce such extraordinary effects. It always conveyed the impression as of one hand playing the melody, and two others interpreting the intricate passages in the accompaniment. His fantasia on the serenade from Don Giovanni was so written that the melody had to be played with the thumb of the right hand, while the other four fingers were rendering the accompaniment staccato. Herein were presented extraordinary difficulties of technique, but the composer surmounted them with the utmost ease, conveying the idea, when he played it, that the piece was simplicity itself.

One of his most brilliant and showy compositions was his celebrated study in A minor. The variation consisted of triplets in repeated notes, and when Thalberg was at the piano it was utterly impossible for the most attentive listener to detect whether the whole treble was played with the right hand, or whether the triplets were taken alternately with both hands.

Thalberg's soft playing was exquisitely tender and touching, but when force was required, he rose fully to the occasion, the whole performance being a marvellous combination of delicacy and power.*

* His use of the pedal was as good as a lesson to any student of the piano. 



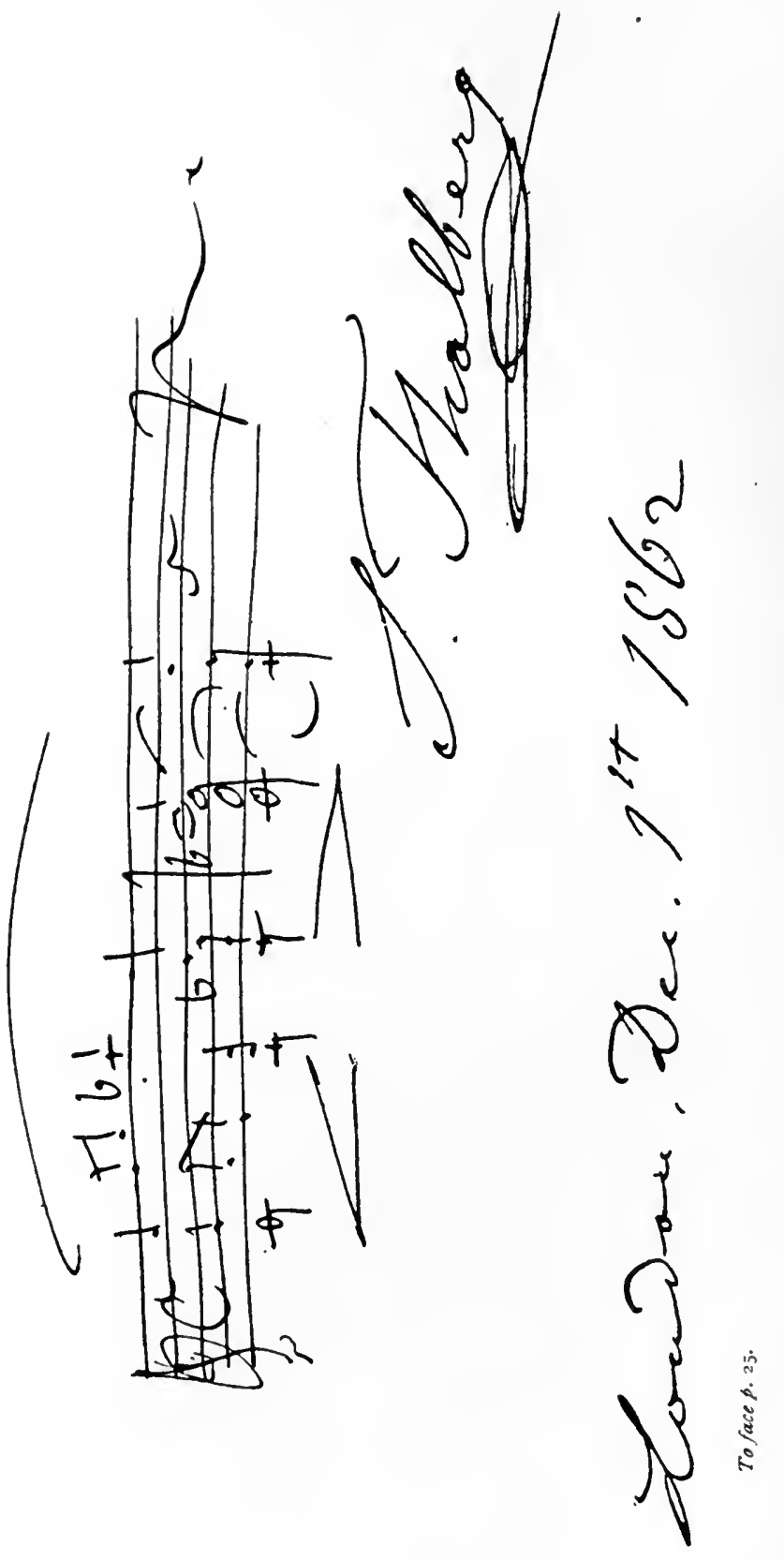


His arrangements of well-known and popular airs were always marked by musicianly treatment, but in the style in which he wrote he found a host of imitators. Which reminds me of a bon mot of his. On one of the last occasions that I saw him, I asked how it was that he had been writing so little of late. (Formerly he had been wonderfully prolific.) With a look half humorous and half pathetic, he replied:

'Alas! my friend, my imitators have made me impossible.'

In many periods of his life I had occasion to listen to his magnificent playing, and some years after that I have mentioned he gave me lessons. At all times he was most kind to me, and evinced a friendly interest in my career. He gave me the manuscript of his fantasia on Don Pasquale and his Tarantella long before these pieces were published. In later years, at one of my concerts in Brighton, I played with him, as a duet for two pianos, his fantasia on airs from Norma.

'Thalberg' was only an assumed name. The artist was the son of Prince Dietrichstein, and married a daughter of the unrivalled basso, Lablache.

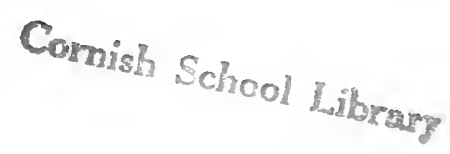




\section{CHAPTER V.}

EARLY MUSICAL MEMORIES

(CONTINUEI)).

My master Tomaschek-His works and pupils-Dreyschock, Schulhoff-Hanslick, critic and friend of BrahmsRomberg, Servais, Bohrer-Regondi's virtuosity on the concertina-Clara Wieck-Clara Novello-Camilla Pleyel -Rubinstein.

My master, Tomaschek, had a world-wide reputation as a composer, as a learned musician, and as a teacher. His works include an opera (Séraphine), several Masses (one a Requiem), a large number of songs, and a host of pieces for the pianoforte. They are original, and some of them merit occasional revival. A few years ago I played his three Ditirambi at a recital in Brighton, where they were so well received that I was obliged by general request to repeat them on a subsequent occasion.

As a teacher Tomaschek was most successful. Among his pupils I need only mention A. 
Dreyschock, J. Schulhoff, and J. Tedesco, who, with many others, attained celebrity. Dreyschock studied at the same time with my brother. Their relations were almost fraternal, and he came daily to our house.

Schulhoff, whom I had known from the age of six, was my schoolfellow. Another fellow-student of mine was Edward Hanslick, who, however, had no intention of following music as a profession. A man of diverse gifts, he now occupies a most enviable position. He not only writes and talks on any subject with authority and effect, and that, I may add, with wit of the brightest, but is, undoubtedly, the most erudite and influential critic in Germany, whose opinions are quoted in every land and tongue. Hanslick, who lives in Vienna, and is the devoted friend of Johannes Brahms, has much in common with that scholarly critic, Mr. Joseph Bennett. They both revere all that is great in Richard Wagner, though they are not numbered among his indiscriminate worshippers, some of whom, in their enthusiasm, presume to condemn the best work of other masters. By this clique Hanslick is thoroughly detested, insomuch that at the first performance of Parsiful at Bayreuth, those who were staying under the same roof refused to sit at table with him. 
Among the great artists who gave concerts in Prague during the years of my studentship were the three celebrated violoncellists, Romberg (then an elderly man), Servais and Bohrer. I also remember the sensation created there by Giulio Regondi's performances on the concertina and the guitar. His mastery of these instruments was not only complete, but phenomenal, and I do not believe his execution has ever been even distantly approached. His taste and phrasing on the concertina were exquisite; while with the guitar his dexterity was so astonishing that he was actually able to render on it Thalberg's fantasia on Les Huguenots. He was as yet hardly more than a boy, while his walk and general appearance were so effeminate that many people remained under the impression that he was a girl in male attire. I renewed his acquaintance years afterwards in England, and met him frequently until his death.

It was, I believe, in ${ }_{1} 8,6$ that Clara Wieck came to Prague. Her beauty won universal admiration, while her playing took the city by storm. Wonderful indeed was the poetic feeling which she drew from the notes as she played in her own peerless style the masterpieces of classic genius. Devoted now, as Madame Schumann, to teaching, she numbers among her foremost 
pupils two of English nationality, Fanny Davies and Leonard Borwick. Conspicuous among pianistic stars of to-day who studied under Madame Schumann is the accomplished Mademoiselle Eibenschuitz. Really worthy disciples of a revered mistress, these artists interpret with consummate skill the noblest compositions of the great masters, whose very thoughts they eloquently convey to the audience instead of trying to astonish by sheer virtuosity. True in this to the example of their instructress, they may be expected to hand down this same tradition to their own pupils, and if, as I venture to hope, teaching plays a great part in their career, the future of pianoforte-playing as an art is assured.

In after-years Madame Schumann played at one of my festival concerts in Brighton. She also gave a recital there, when she performed with me her husband's variations for two pianos.

From Prague Clara Wieck went to Vienna, where she was equally admired. Curiously enough, there was at the same time giving concerts in Vienna another Clara, an English lady as beautiful as she was gifted, who met with enormous success. I refer to Clara Novello, then in her first youth. 
The Vienna concerts of I 839 included several given by Camilla Pleyel, the most brilliant of lady pianists at the time, and the favourite pupil of Kalkbrenner. I remember in particular one of her recitals, when Liszt turned over the leaves for her. She visited London in the forties, and again in 1852 .

In I84I Anton Rubinstein (then eleven years old) gave concerts in Prague, and the most wonderful career was predicted for him by all who heard him. For once prophecy was not belied. 


\section{CHAPTER VI.}

\section{PROFESSIONAL BEGINNINGS.}

Studies near Salzburg - First concert-tour - Metternich at Ischel, and later in Brighton-Munich-Franz LachnerInterview with King Louis of Bavaria-An entertaining Monarch - Stuttgart - The Queen of Wurtemberg Pischek - Molique's advice as to visiting England Pischek my fellow-traveller-Importunate officials.

FROM I 843 to I 844 I spent a twelvemonth in the neighbourhood of Salzburg, studying and preparing for my concert-tour, during which I visited Ischel, Salzburg, Munich, Augsburg, Ratisbon, and Stuttgart. At the first-named place I was most kindly received by Prince Metternich, the famous Austrian statesman, and played frequently in his salon. He was already old, but strikingly handsome, and I have never seen a more aristocratic-looking personage. In $\mathrm{I} 848$ he was a fugitive, having been driven from Austria by the Revolution. He spent the winter in Brighton, 
where I frequently visited him. He was always most kind to me, but he took every opportunity of complaining bitterly of the ingratitude of the Austrian people. Prince Metternich was not merely fond of music, but understood it thoroughly. His son Richard, Austrian Ambassador in Paris during the second Empire, inherited his father's love for the art.

In Munich I gave several concerts. Franz Lachner, who was then conductor of the Court orchestra, and head of all musical matters, engaged me to play Hummel's Concerto in $B$ minor at one of the orchestral concerts under his direction. $\mathrm{He}$ was a man of European reputation, and as a composer quite a classic. He wrote several operas, among the more successful being Catarina Carnaro, which achieved extensive popularity. His prize symphony and many of his songs and orchestral pieces are still performed from time to time, and justly admired. As conductor he occupied the foremost place among his contemporaries.

King Louis, then quite an old man, most graciously desired that I should have audience of him before I left the Bavarian capital. I found him most agreeable and entertaining. It happened that the apartment in which he received me 
possessed three doors, and I was doubtful by which to leave. Perceiving my embarrassment, the King laughingly remarked: 'There are three doors, as in Mozart's Flauto Magico; but the middle one is the only right one by which to enter and to leave' ('Bie mir sind drei Thüren, wie in Mozart's Zauberflöte, aber nur die Mittelthuire ist die rechte und wahre, durch welche man kommt und geht').

In Stuttgart I gave a series of concerts, and played several times at Court. The Queen of Wurtemberg took such a fancy to one of my compositions-Das Glockenspiel, an imitation of a musical box-that I dedicated it to her, and Her Majesty acknowledged the compliment by presenting me with a ruby ring set in diamonds.

During my stay in Stuttgart I made the acquaintance of Pischek, a singer possessed of one of the most beautiful baritone voices it has ever been my good fortune to hear. Being on the eve of departure for London, Pischek urged me to be his fellow-traveller. I took counsel with Molique, who strongly advised me to go, saying that a visit, if only of a few weeks' duration, would be of the greatest benefit to me, and might even lead to my settling in that huge, wondrous capital. With this the matter was settled. 
Travelling in 1845 was not what it is now. The journey from Cologne to Brussels occupied fully ten hours, the road thence to Ostend being covered in not less than six or seven, while the sea-voyage from Ostend to Dover was a matter of at least eight hours. The railway-stations in Belgium were small and frequent, and our train halted religiously at every single one of them. Nor did the guard fail at each stoppage to enter the carriages with his everlasting 'Les billets, messieurs!' Pischek's natural irritation at the exasperating repetition of this request at last tempted me to perpetrate a practical joke. I began by remarking that, to remain unmolested, he had merely to tell the guard that he had already shown his ticket. Pischek, I ought to say, understood not one word of French. He accordingly begged me to furnish him with a phrase suitable for the purpose. "Simply say, "Allez vous en," ' replied I. And so he did the moment the guard appeared at the door of our carriage, with what effect I leave the reader to imagine. But Pischek was utterly unable to understand what it was that had aroused the fury of the railway servant, and it was some time before I could pacify him, and induce him to produce the talismanic pasteboard. At the next 
station, however, another guard came on the scene, and, meeting with a similar reception from Pischek, was even more abusive than his colleague. Fortunately, at the moment, another passenger entered the carriage, and, on hearing the cause of the squabble, informed Pischek of his apparent rudeness, which I need not say he did not repeat. I will merely add that he took my joke most good-naturedly, and never referred to it without a hearty laugh. 


\section{CHAPTER VII.}

MUSICAL LONDON IN 1845.

Arrival in the Metropolis-First impressions-Welcome from Moscheles and Benedict-First visit to Her Majesty's'Long Thursdays'-Grisi, Mario, Fornasari, and Lablache in I Puritani-Expectations not wholly realized-Grisi criticized and compared - Mario - His contemporaries and successors - Moriani - Hausmann's friendliness Madame Dulcken-Musical critics of the day: J. W. Davison, Morris Barnett, Gruneisen, Chorley-Stars of r 845-Leopold de Meyer-Vieuxtemps-Alvars-Kellerman-Staudigl-Pischek's success-Madame Carradori Allen-Artists and sense of pitch-A significant incident.

WE arrived in London on the morning of Thursday, May I, I 845. I shall not attempt to describe, though I can certainly never forget, the impression made upon me by this vast Metropolis. The life, the bustle, the extraordinary number of conveyances of all kinds in the endless streets, filled me with an astonishment which was well-nigh overwhelming. We put up, I remember, at the 
London Bridge Hotel, now no longer in existence.

My first visit was to Moscheles, who resided in Chester Place, Regent's Park, where I met with the kindest possible welcome. My next call was made at the house of Julius Benedict in Manchester Square. I had letters of introduction to him from members of his family in Stuttgart, where their wealth, as well as their high character and artistic tastes, had secured for them an enviable social position. Here, too, my reception was most cordial.

The same evening we went to the Italian Opera at.Her Majesty's Theatre in the Haymarket. At that time only three performances were given each week-on Tuesday, Thursday, and Saturday. Two evenings-Tuesday and Saturday-were included in the subscription, the Thursdays being extra nights, known as 'Long Thursdays.' On these occasions the performance consisted of an opera, followed by a rather long ballet, which in turn was succeeded by an entire act from another opera, and a second choregraphic display-a prodigious programme, forsooth!

On the occasion of our first visit to Her Majesty's, the opera was Bellini's I Puritani. Later, after the usual ballet, we heard the last scene from 
Lucia; but we did not remain for the final item, a children's ballet, directed by a Madame Weiss, from Vienna. The beauty of the theatre, the brilliant toilettes of the ladies, the regulation evening dress worn by the men and by the members of the orchestra, were sights to which I was totally unaccustomed, and by which I was proportionately impressed.

The cast in I Puritani included Grisi, Mario, Fornasari, and Lablache. I had read so much in the German newspapers about these gifted singers that I had formed expectations of them too great to be wholly realized. Grisi-albeit splendid to behold, and possessing a lovely voice-did not satisfy me so completely as Jenny Lutzer, whom I had seen in the same opera at Vienna. Some years later, when I heard Grisi in Lucrezia Borgia and Norma, I greatly modified my first opinion of her. In Norma she was distinctly great, and never had a wurthy rival. I must, however, except her rendering of Casta Diva, in which aria she has been surpassed by Jenny Lind, Adelina Patti, Albani, and others-in fact, I will go further, and say she never sang it well. Fornasari, equally favoured in feature and in voice, I nevertheless could not admire. Old Lablache, whom I afterwards considered the most consummate genius in 
comic opera ever known, likewise disappointed me on that occasion, probably because he omitted his great aria, which, to my mind, is almost the best thing in the opera, and which I had been accustomed to hear sung in irreproachable style by Stauaigl in Vienna.

But how am I to describe Mario? The impression he left that evening on my memory can never be effaced. He was then only a beginner, and a most indifferent actor (though later an excellent one), but his voice, his looks, his bearing - in fact, everything about him-seemed too fascinating for words. Pischek, although greatly delighted, preferred Rubini, whom he had heard a few years previously at Frankfort. It was my good fortune to listen to Mario times out of number. He became a close friend, and often sang at my concerts. He had contemporaries and successors, who gave (and still give) me intense pleasure; but none, in my humble opinion, ever equalled him. In Lucia Moriani sang and acted the Death scene very finely, true to his reputation of being unrivalled in scenes of this description, although the freshness of his voice had left him.

Midnight had struck before the curtain rose on the final ballet. But we had already passed four hours in the theatre, and, appreciating the aptness 
of the designation 'Long Thursday,' we sought our hostelry without delay, not unnaturally fatigued after the sights and shows we had witnessed upon our first day in England.

Next day I delivered more letters of introduction. My first call was made on Hausmann, the celebrated violoncellist, a very lank and extremely emaciated man, who enjoyed considerable social popularity. Few were the concerts, public or private, for which Hausmann was not engaged. Nothing could have exceeded his interest in me. He adored Molique, and the fact of my having been so warmly recommended by him made Hausmann exert himself to the utmost in befriending me. He at once secured lodgings for me in Great Marlborough Street, and accompanied me everywhere in visiting those to whom I had letters of introduction.

That same day I called on Madame Dulcken, at whose house I was made so welcome that until her premature death, some five years later, I was a frequent visitor.

Hausmann introduced me to all the musical critics of the day, including J. W. Davison (Times), W. Hogarth (Herald), Morris Barnett (Morning Post), Gruneisen (Chromcle), and Chorley (Athenaum). 
Among the celebrities who came to London that season were Leopold de Meyer, a very sensational pianoforte virtuoso; Vieuxtemps; Parish Alvars, the king of harp-players; and Kellerman, a Danish violinist of extreme proficiency, who became a great favourite. Staudigl was already quite an institution, and without his co-operation no concert, public or private, was considered complete; but Pischek, who made his first appearance at a concert given by Madame Carradori Allen (in the concert-room adjoining Her Majesty's Theatre), a few days after our arrival, at once took the public and the press by storm, becoming Staudigl's serious rival. His voice-a baritone-was so beautiful in quality, and the songs he introduced achieved so immediate a popularity, that engagements poured in by every post. He returned, indeed, to Stuttgart, after a six weeks' sojourn in London, with his pockets heavier by $£ \mathrm{I}, 200$, and with engagements booked for a far larger amount for the ensuing London season ( 1846 ). His two best known songs were Mein Herz ist am Rhein, by Speyer, and The Standard-bearer, by Lindpeintner. They were heard everywhere, the latter having been scored by Moscheles, in order that it might be sung by Pischek together with Spohr's Liebe 
ust die zarte Bliithe, at the concerts of the Philharmonic Society, of which Moscheles had just been appointed conductor.

Madame Carradori Allen had engaged all the artists of the Italian Opera, including Grisi, Mario, Lablache, Moriani, Fornasari, and others, besides Leopold de Meyer, who played a most effective piece-Marche Marocaine - and Vieuxtemps. But Pischek's success led all the rest. He was, as I said before, a baritone, but he sang up to A flat in the last verse of Speyer's song, which created quite a furore among the Italian singers. This achievement was the subject of much discussion among the artists; but it astonished me to find that old Lablache was the only one of them who could positively be certain that the note was indeed an A flat. Nowadays, I suppose, such lamentable ignorance would hardly be met with in any school of music, let alone in an assemblage of professional singers of note. 


\section{CHAPTER VIII. \\ MUSICAL LONDON IN 1845 \\ (CONTINCED).}

Henry and Walter Broadwood-J. B. Cramer-Joseph RiesGeorge and Frederick Rose-John and Algernon BlackA. J. Hipkins - Frederic Beale, an art-promoting publisher and concert-giver - Benedict's concerts - A programme of forty numbers-John Parry - His nervousness -Thalberg his great admirer-Mr. Ella's Musical Union - My first concert in England at the Beethoven Rooms -Alvars' amiability.

Among the letters with which I was furnished by Molique before leaving Stuttgart for London were two which admitted me to the friendship of two firms whose names will ever remain in high esteem among the musicians of this country. One of these letters was addressed to the house of Broadwood, and the other to Frederic Beale. On - presenting the first, I became acquainted with Walter Broadwood, and later with his brother Henry. The cordiality with which I was re- 
ceived by these generous, open-hearted men can only be fully understood by those who have shared with me the great privilege of knowing them. The material aid they afforded me on countless occasions I can never forget; nor do I yet cease to entertain for them feelings of the deepest gratitude.

Happening to call on the Broadwoods one day in 1846 , Henry took me into his private room, and introduced me to J. B. Cramer, then an old man of seventy-five. My interest and delight were indeed great, thus to become acquainted with one whose 'studies' have made his name a household word. He was induced to play to us, but I confess that his execution made no great impression upon me. Naturally, I had formed an ideal of his powers which, at his advanced age, it was scarcely possible could be realized. He died, in I 858, aged eighty-seven. My friendship with Walter and Henry Broadwood brought me into contact with many estimable and clever men connected with their establishment. Among those of them who honoured me with their friendship, I cannot forbear mention of Joseph Ries (brother of the celebrated composer Ferdinand Ries, pupil of Beethoven), the brothers George and Frederick Rose, John and Algernon Black, and Mr. A. J. 
Hipkins, the great authority on ancient and modern musical instruments.

What am I to say of Frederic Beale, whose nature was as thoroughly kind and genial as it was completely artistic? Many were the works he published by which he was certain to lose a great deal of money, simply because he thought them worthy to see the light. Happily, he was not without imitators in this respect, for those were days in which pecuniary considerations sometimes made way for the interests of art. Mr. Beale was one of the promoters of the Royal Italian Opera, Covent Garden, and arranged innumerable opera and concert tours in the provinces. The generous friend of struggling musicians, he was thus able, not only to counsel, but to help them substantially to carry his advice into effect. Grisi, Alboni, Mario, and Thalberg were something more than his friends: they simply idolized him. His son Willert, who died last year, inherited his father's mantle as entrepreneur, making friends quite as easily. And a dear, kind, good fellow he was!

I remained in London till the end of June, attending during my stay every important concert and operatic performance, besides taking part in many notable social gatherings. Among the con- 
certs, I remember in particular those given by Madame Dulcken and Julius Benedict. They took place, like those of Madame Carradori Allen, at the hall adjacent to Her Majesty's Theatre, Benedict's concerts always taking the lead in point of significance. Benedict, indeed, was the most popular musician England had ever known. For his concerts he engaged all the great vocalists and instrumentalists of every nationality who happened to be passing the season in London. His programme on the occasion of my visit included more than forty items. Some music-lovers there were who, undismayed, remained to the end, though, I confess, I was not numbered among them.

Of one artist I must make special mention, for in his way he was nothing less than a genius. I refer to John Parry, who not only played the pianoforte with all the refinement of a cultivated musician, but possessed an apparently inexhaustible fund of humour. He invariably contributed to the programme a sketch in the style made familiar to the present generation by Corney Grain and George Grossmith. As a rule, he prefaced these sketches (some of which, unless I am much mistaken, were written by Albert Smith) with a medley of all the popular tunes of the day, operatic and otherwise. 
He frequently joined in provincial tours with the foremost singers of the day, Thalberg being often the pianist. The latter confided to me once that he so admired John Parry that he never missed an opportunity of hearing him. Like many true artists, Parry was exceedingly nervous, and his wife was at hand whenever he performed, lest he should break down. Her presence inspired him with confidence. His innumerable engagements, nevertheless, began in time to tell upon him, and he was forced to retire for some years, emerging again only at the instance of his friend German Reed, who persuaded Parry to join him and his gifted wife in their famous entertainment. It was my good luck to be present at his reappearance in the company of this clever couple at the Gallery of Illustration, and to witness the extraordinary enthusiasm with which he was received.

Among the engagements which I obtained during this busy visit was one at Mr. Ella's Musical Union; and before my departure Moscheles kindly arranged for me a concert at the Beethoven Rooms (now no longer in existence), in Harley Street, in connection with which I will recall one incident. Parish Alvars, the greatest harpist ever known, was among the celebrities then in London. 
He was the originator of those elaborate passages in the upper and lower registers of the instrument, serving to ornament a melody played in the middle, a combination which Thalberg was the first to imitate on the pianoforte. I was advised to call on him and ask him to assist at my concert, as no programme was considered quite complete in which his name did not figure. Not knowing him in the least. I felt considerable hesitation about visiting him ; but at length, taking courage, I ventured to do so. Alvars, who spoke German fluently, soon put me at my ease, and, on hearing my request, at once replied :

'Most certainly. I have been so kindly received in Germany, and I always like to show my gratitude by assisting Germans.'*

My little concert over, I left England, so delighted with the country, the people, and the hand of fellowship extended to me, that I made up my mind not only to return to London in the following season, but to make it my future home.

* A year or two later Godefrois, a celebrated French artist, made a great success, particularly with his Danse des Sylphes, which he played on every possible occasion. At the present time Mr. John Thomas is a most worthy successor of these two masters of the lyre. His playing is not only most refined, but he is a thorough artist in every sense, and a most amiable gentleman. 


\section{CHAPTER IX.}

SIMS REEVES.

Mr. J. M. Levy-Sunday Times-Compositions of Miss Levy - How I made my first appearance in London-Miss Lucombe-Emma's dilemma-Début of Sims ReevesAn unexpected success - John Braham-'Wednesday Concerts' at Exeter Hall-Artists' salaries then and now - The losses of a gifted singer.

IT was in this year that I was introduced to $\mathrm{Mr}$.

J. M. Levy, then the proprietor of the Sunday Times. From the day I made his acquaintance until his death, in I 888 (a period of forty-two years), he was my closest and most loyal friend. At the hospitable house of this kind and artloving gentleman, about whom I shall have more to say in a future chapter, I made the acquaintance of many distinguished representatives of art, science, literature, music, and the drama. Mr. Levy's eldest daughter, Angelina, possessed rare musical ability, being an accomplished pianist, and 
the writer of not a few charming compositions. Some of her songs, indeed, notably Solitude and Fischlein-refined and graceful melodies-obtained great and deserved popularity. She married my friend, the late Mr. Goetz, and at the present day her house is a centre of art, and the scene of constant symposia of prominent musicians, actors, and dilettante.

It was through the instrumentality of Mr. Levy that I made my first public appearance in London. The occasion was a 'grand evening concert,' given at the Hanover Square Rooms-then the largest and most fashionable concert-hall in the Metropolis -by Miss Emma Lucombe, a very excellent singer, who in after-years became Mrs. Sims Reeves. Among other artists, the beneficiaire had secured the services of the well-known pianist and popular composer, Henry Litolff. On the morning of the concert she found that he would be unable to fulfil his engagement, and, curious as it may appear nowadays, she was at her wits' end to know in what direction to turn to find a substitute. In her dilemma she conceived the idea of consulting her friend Mr. Levy, who took a generous interest in her career, as he did in that of most artists who were fortunate enough to know him. He at once recommended me as Litolff's 
substitute, and the suggestion was promptly acted upon. The audience-a crowded one--was very indulgent, and this appearance paved my way to many subsequent engagements.

In the same year I had the good fortune to be present at the début in England of Mr. Sims Reeves. This was at a miscellaneous performance given at Drury Lane Theatre. The then unknown tenor came without any preliminary flourish of trumpets, and consequently little or no curiosity was manifested in his appearance. He sang the Fra Poco from Lucia, and hardly had he concluded the opening recitative, when it became clear to the whole audience that the future king of English tenors stood before them. Not only the voice, but the singer's method of producing it, was sufficient at once to convince his rapt hearers that he had no rival. Sims Reeves, good fellow, kind-hearted gentleman, and loyal friend, has now been before the public for close on fifty years, and he still, let me say, charms all true musicians by his exquisite taste and perfect phrasing. When first I knew him he sang in Italian and English opera and oratorio, while at concerts whereof ballad music formed the staple fare he was, and remained for many years, the pre-eminent attraction. 
I regret to say that it was not till some years later that I first heard his illustrious predecessor, John Braham. He then emerged from his retirement in order to sing at what were called the 'Wednesday Concerts' at Exeter Hall. A very old man then was Braham (1848). Certainly he sang with an astonishing amount of energy and force, considering his age; but it was impossible to form anything like an adequate idea of his powers as a young man. However, I recollect at the time hazarding the opinion that any comparison between him and his successor, Sims Reeves, could not possibly have been unfavourable to the latter.

By the way, apropos of Sims Reeves, I cannot refrain here-if I may do so without giving offence to one for whom I have always entertained the warmest regard-from reminding those of my readers who are not 'behind the scenes,' and who may be prone to deny to the famous tenor the right to emerge as he has so often done from retirement, of a wise French saw which tells us that 'Tout savoir, c'est tout pardonner.' Thoughtless people, persons who are ever ready to form rash conclusions, and make hasty and unwarranted assertions, are, I know, apt to blame the aforetime idol of the public for a state of things which in 
reality should arouse a feeling of sympathy in all who have been held in thraldom by the magic of a matchless voice, which times out of number has touched the heartstrings of the multitude. To all such I would say, with more sincerity than mere words can convey: 'Pause; look on the blameless life and brilliant career of a man who has given, perhaps, more genuine and refined pleasure to music-lovers than any artist of any country, and then ask yourselves the question, Is it right, is it generous, is it manly, to invent reasons for condemning one upon whom, in his old age, fickle Fortune has refused to smile?'

I consider it is high time to speak out in this matter. Over and over again one hears it said, -What earthly right has Sims Reeves to appear in public again after he has retired and invited people to pay to hear him sing for the last time?' And again, 'Reeves must have made hundreds of thousands of pounds in his palmy days, and he ought to be well off now.' It is against such criticism-irresponsible, careless, heartless criticism from outsiders who know nothing of the domestic life and generous instincts of the artist thus maligned-that I would most emphatically protest. Is it conceivable, one might well ask, that an artist, nervous, highly strung, sensitive to the tips of his 
fingers, would undergo the ordeal of singing in public, and courting comparative failure, with the memory of past triumphs ever present in his mind, if necessity did not compel him to do so? And is not the very fact that an artist who, so to speak, has had the world at his feet, and carried all before him in days of yore, should be driven to this necessity, enough in itself to inspire feelings of deep commiseration, and disarm censure?

Let the plain truth be spoken. Those who talk so glibly about the 'palmy days' of Sims Reeves, and who, by the way, can have no conception of the then indescribable beauty and perfection of that exquisite voice of his, are seemingly oblivious to the fact that there was a time when artists, were they never so great, did not and could not command the exorbitant, and almost prohibitive, 'terms' which obtain nowadays on the concert platform and the lyric stage.

In those 'palmy' days, even a public idol like Sims Reeves would not have dreamt, in his wildest moments, of asking more than twenty or twenty-five guineas for singing a few ballads - and how he sang them!-or in an oratorio. And it was not till many years after - at a time when failing health often prostrated him with nervousness, and he was compelled again and 
again to disappoint audiences, and thereby suffer heavy pecuniary losses-that he really obtained high terms. Indeed, I do not think I am outside the mark when I hazard the belief that he lost as much money by not singing as he ever made by fulfilling engagements.

Nevertheless, there was a time when many people were foolish enough to think that, by reason of his phenomenal powers of attraction, Sims Reeves used to stipulate with managers and concert-givers that even if he was too ill to appear he must receive a portion of his fee-that, in fact, entrepreneurs and himself were in conspiracy to deceive the public by trading upon the attraction of his name only. A greater and more astounding libel on an honourable man was never uttered. And yet I can testify to the fact that such an impression at one time prevailed in public circles, having myself been asked on several occasions when Reeves had been unable, through indisposition, to sing at concerts for which I had announced him, whether I had to pay him for 'putting his name on the bills.' But on the subject of the ignorance of a portion of the concert-going public in these matters-notably the payment of artists -I could almost fill a volume from my own experiences. 


\section{CHAPTER X.}

SIR MICHAEL COSTA.

The composer's works-What he did for orchestral playersHis love of punctuality-A story about his oboe-playerAppreciation of the composer by the Royal Family.

When I came to London in I 845 , Sir (then Mr.) Michael Costa was conductor of the Italian Opera at Her Majesty's Theatre. A singularly gifted and, in some respects, very remarkable man was the composer of Eli. Before my arrival in England, operas from his pen had been produced, but, to my knowledge, they have not been played since, and certainly I never remember to have heard even excerpts from them. The oratorio which I have mentioned, however, and with which his name as a composer is chiefly identified, enjoyed enormous popularity. In fact, it was, without doubt, the most esteemed work of the kind written since Mendelssohn's Elijah took the musical world by storm. 
As a conductor, Michael Costa deservedly enjoyed an unrivalled reputation, and he was never happier, as he often told me himself, than when he held the bâton. Not only did he inspire the utmost confidence in the ranks of his forces, but every member of the latter almost worshipped him. Of not many conductors could as much be said. But there was a very substantial reason for the complete understanding that existed between the players and their master. Before Costa came upon the scene, the status of an orchestral performer was a very low one. In fact, it was an 'unknown quantity'; and extraordinary as it may now appear, the members of an orchestra were treated as contemptuously as though they constituted quite an unimportant factor in the scheme, upon their share in which, as a matter of fact, so much necessarily depended. As a consequence, orchestral players, as a body, lost their self-respect, and performances in which they were engaged not infrequently suffered.

But Costa changed all this. If he could not raise their salaries, he at any rate contrived to raise their artistic worth in the estimation of those whom they served. I somehow cannot help thinking that the historic orchestral performer who is credited with a poetic lamentation 
because of finding himself in the ignominious position of having to play the principal flute 'for a paltry two and eleven,' must have enriched himself at this figure before the days of the illustrious conductor of whom I an writing. Had he exercised his talent on the gentle and mellow instrument at any later period, he would surely have established his claim to the odd penny, which would have placed him on a financially sound basis.

Be this as it may, it was to him that orchestral performers, from the bass-drum player to the 'first violin,' owed an altered position of affairs, in which they came to be looked upon both by operatic managers and vocalists as artists entitled to a full measure of consideration and respect. And to show how determined was the conscientious conductor to uphold the rights of his forces, let me narrate how every Saturday, when they went through the agreeable ceremony of receiving their salaries, he made a point of being present to see that no injustice was inflicted on the hard-working instrumentalists, and that their share in the week's work was properly rewarded. In these circumstances, is it to be wondered at that they loved and respected him? So it came about that when, in $\mathrm{I} 847$, he severed connection 
with Her Majesty's, and became chef d'orchestre at the rival establishment, every member of the band followed him; and when again, some years later, Costa had a disagreement with the manager of Covent Garden Theatre, several of the performers (to mention only two well-known names, Sainton and Lazarus) declined to serve under any other leader, and for a time were consequently without operatic engagements.

Rossini, Mendelssohn, and Meyerbeer all regarded Costa as a magnificent conductor. In no circumstances would he permit any performance to take place without a sufficient number of rehearsals. There must be nothing slovenly or artistically unsatisfying about any representation. And kind and generous as he was to his orchestra, and solicitous, as will have been seen, for their welfare, he was a strict disciplinarian, and exacting to the last degree. For example, one of his most salient characteristics was punctuality, which he carried almost to the extent of a mania.

in this connection I can relate a somewhat amusing episode. At the rehearsal of a concert which he was conducting in London, every member of the orchestra was duly seated at the appointed time save one. This was the second oboe-player. Needless to say, Sir Michael was 
not slow to detect his absence, but he waited a few moments without making any remark. In the meantime his face began to show irritation, and as the minutes sped, and the absentee failed to make his appearance, the signs of annoyance thus betrayed became intensified, and the instrumentalists were preparing themselves for a veritable tempest. With a patience, however, which for him was phenomenal, the conductor waited fully half an hour, at the expiration of which time, replacing the watch which he had been holding in his hand in his pocket, he tapped the desk with his bâton, and the rehearsal commenced.

About a quarter of an hour afterwards the oboe-player arrived, breathless, panting and looking as sheepish as a truant schoolboy. At once the irate conductor stopped the rehearsal, and, addressing the late-comer in withering tones, said: "Mr. N—, do you know what the time is?' With a thousand apologies, the unfortunate man, towards whom the glances of all his confières were turned, proceeded to unfold his explanation, which was to the effect that a peculiarly domestic event had just occurred in his home, and that he did not like to leave until he was assured that everything had passed off 
satisfactorily. General laughter greeted his unexpected explanation, and one wag in the orchestra increased it by inquiring whether it was 'oboe' (a boy). But Sir Michael did not join in the merriment. However, on hearing the explanation his features relaxed somewhat, and, turning to the late oboe-player, he said: "That is a different thing. You may take your place, but, mind, don't let it occur again.' A burst of laughter followed the 'free pardon' thus quaintly delivered, and the rehearsal then proceeded in peace.

On one occasion the composer's love of punctuality manifested itself in a curious fashion. He was staying at my house in Brighton during a Festival week, and one evening my wife had, to meet the wishes of our guest, arranged dinner for seven o'clock. Knowing full well his idiosyncrasy, she had given special injunctions to have the meal served punctually at the appointed time. With unfailing precision Sir Michael appeared in the drawingroom five minutes before the dinner-hour, and for the next few moments conversed with my family. On the stroke of seven he took out his watch, compared it with the clock on the mantelpiece, which had just struck, and then, by way of signifying his approval at the accuracy of our 
timepiece, rose from his chair. But no gong had been sounded, and during the moments that ensued Sir Michael paced up and down the room, keeping his eyes on his watch. He had not long to wait, for at two minutes past seven dinner was announced, and the reputation of the house was saved. The distinguished composer, however, was not of this opinion, for in offering to my wife his arm in order to escort her into the diningroom, he remarked with a gravity that might have been warranted had he just learnt of the death of a dear friend, 'Mrs. Kuhe, your cook, I am sorry to see, is two minutes behind her time.'

After I $\delta_{4} 6$ Sir Michael Costa was conductor of the Philharmonic Concerts, the Birmingham Festival, the concerts of the Sacred Harmonic Society, and the Handel Festival at the Crystal Palace. He was very much liked by the Queen, who accepted the dedication of his first oratorio; and the Prince of Wales held him in such high esteem that, when the composer, towards the close of his career, was lying dangerously ill, he not merely sent to inquire after him, but frequently called himself, and sat at the bedside of the sick man. Sir Michael bequeathed his fortune to his brother Raphaelo, and on his death it was to revert 
to the Royal Academy of Music.* But, unfortunately, the lamented composer failed to take proper legal advice; the will was imperfectly drawn up, and, as a consequence, nothing to this day has, I believe, been settled as to who will inherit his property. I may add that Sir Michael, who was always a good, kind friend to me, and proved of invaluable assistance in connection with my Brighton Festivals, was an ardent Freemason, and held high office in the craft.

* He left the money to found a scholarship for students who showed the greatest talent for inventing melody. This is interesting, as showing that he was not one of those who placed what might be called the 'mathematics' of music above the art of writing unforced and simple melody. 


\section{CHAPTER XI.}

\section{JENNY LIND.}

My first impressions of her in 1846 -Some of her operatic successes - Meyerbeer's Camp in Silesia - Its historical significance-An awkward law-How the difficulty was overcome-A new libretto for the operaL'Etoile du Nord - A reminiscence of Patti - How Frederick the Great became Peter the Great-Jenny Lind at Her Majesty's Theatre in I847-A memorable season - Seats at a premium.

THE winter of 1846 was one of the most eventful and memorable in my musical career. It was in November of that year that I heard for the first time the magic voice of Jenny Lind, and I feel I cannot bring myself to write of that incomparable artist-of my first impressions of her matchless vocalization, and of my after-years of artistic association with her-with ordinary restraint. What shall I say of those never-to-be-forgotten first impressions? For years I had heard so much concerning her gracious gifts, that it seemed 
almost impossible that my expectations should be more than in part realized. And yet need I say, as all who ever heard her can understand, that my anticipations were more than fulfilled? But, in truth, so much has been written of that wonderful singer, that it is not for me to attempt a criticism of her voice or methods. Still, one or two personal impressions I may be allowed to recall. Thus, concerning her voice, I might mention that in her opening phrase the sound produced was always what the French call voile; but after the first few bars it gradually became clearer and clearer, producing an impression as of the sun beginning to shine brightly through a gentle haze, its rays ultimately penetrating through the mist with all their brilliancy. I may truly say that I have never once heard Jenny Lind fail even in the most difficult piece of vocalization. The effort was always perfect, indescribable, and marked by the most intense feeling. Small wonder, then, that the greatest musicians of her epoch-making day - among others, Schumann, Mendelssohn, and Meyerbeer-declared, as with one voice, that nothing like it had been heard before.

Few who remember her in her zenith will deny that Jenny Lind was as great an actress as she was a singer. Her Amina (Sonnambula), her 
Figlia del Regimento, Lucia, and Vielka, in Meyerbeer's Das Feldlager in Schlesien (The Camp in Silesia), were memorable examples of her histrionic achievements. Her singing of Casta Diva can never, surely, fade from the memory of those upon whose ears it fell.

I have alluded to the character of Vielka, and it may be interesting here to recall that the opera already named, and of which Vielka was the central figure, was composed expressly for the opening of the (then) new Opera-house in Berlin. The libretto dealt in part with an interesting portion of Prussian history, the hero being no less illustrious a personage than His Majesty Frederick the Great. Now, according to a time-honoured law of the country over which he ruled, no one who ever sat on the throne of that kingdom could be represented on the stage. Be the monarch good, bad, or indifferent, neither his fine qualities nor his foibles must be depicted behind the footlights. Thus the law prescribed then, as I believe it does at the present day. So, in the case of this particular opera, here was a pretty difficulty. When I state that to escape from it recourse was had to a scheme whereby the King was only alluded to in song-albeit, in one act his im- 
personator was heard behind the scenes tootling His Majesty's favourite instrument, the flute-the absurdity of the situation thus brought about will at once be realized; and it will be seen that such a libretto became an impossibility. The work, on that account, secured but few representations in Berlin, while in Vienna it was only brought to a hearing in order to give opera-lovers in that city an opportunity of seeing Jenny Lind in the part.

After that it was put on the shelf, until (I think in I 853) Meyerbeer obtained an entirely new libretto for his score, of which he retained the overture and some eight other numbers, including the whole, or nearly the whole, of the second act, and then, in its new guise, and under the title, now so familiar, of L'Etoile du Nord, was produced one of the composer's most enduringly-popular operas.

Well will London opera-goers of twenty years ago, and less, remember how magnificently Adelina Patti sang and acted the part of the heroine in L'Etoile and how elaborately the work was staged at Covent Garden by the late Frederick Gye. Of course, as all students of opera know, Peter the Great was substituted for the Prussian monarch ; but the part was made a strong signing 
and acting one, and in the hands of Faure became a splendid and effective character. And it may be of interest to add that the famous scene of the prima donna with the two flutes is a survival from the luckless original version, as composed expressly for Jenny Lind. It is a pleasure even now to recall the astonishing ease and brilliancy with which that great artist rendered these intricate flute passages. But perhaps the most remarkable feature in that particular tour de force was the difficulty experienced by the most attentive listeners in distinguishing between the soft and cooing notes of the flutes and those that came from the singer's own voice.

Nothing within my memory ever exceeded the rapturous enthusiasm with which the distinguished artist was received in May, I 847, on the occasion of her first appearance as Alice in Roberto, at Her Majesty's Theatre. Throughout that memorable season-one historic in operatic traditions-there was what I might call a 'Jenny Lind fever.' In society, at home, and in public, one talked of nothing else; and so unbounded was her popularity, and so unique her 'drawing' powers, that it was impossible to obtain stalls for a single performance at which she appeared for less than five guineas. Frequently, indeed, the price rose 
much higher, while the sums paid for boxes ranged from fifty to eighty guineas, so that it will be readily understood that librarians and enterprising ticket-dealers realized for once small fortunes. 


\title{
CHAPTER XII.
}

\author{
JENNY LIND
}

(CONTINUED).

Her private life-Acts of benevolence-An English tour in I $848-£$ I 0,000 given to charities-Kindness to brother and sister artists-How she came to sing for me at Mannheim-A lucky accident-Opposition happily avertedA generous offer-A memorable concert-The 'Swedish Nightingale'-Queen Adelaide-An evening at St. James's Palace-Gardoni and Lablache-A Royal assemblage.

OF Jenny Lind as an artist I have been led, by the force of personal appreciation, to write more perhaps than I had at first intended. With regard to the personal character of Madame Otto Goldschmidt, so many are the stories related of her kindness of heart, her unfailing good-nature, and her innumerable acts of benevolence, that I feel there is little or nothing left to be recorded. Those music-lovers who, apart from the art which she so conspicuously adorned, have derived a genuine pleasure in becoming acquainted with 
another phase of her career, have doubtless read Henry Scott Holland and W. S. Rockstro's Jenny Lind, the Artist, which gives a clear and truthful insight into the domestic features of Madame Goldschmidt's life. I will therefore merely add that the whole of it was devoted to her art, and to the doing of unselfish good.

In 1848 the diva had a two months' tour of the English provinces, and in each week the proceeds of one of the concerts were devoted to charitable purposes, the total sum raised in this manner amounting at the close of the tour to $£ 10,499$. Let it be recorded also that Jenny Lind never in any circumstances accepted remuneration when singing for professional musicians. Thus, on several occasions, she volunteered to give her services for Madame Schumann, while, among others, Balfe, Sir Julius (then Mr.) Benedict, F. Lablache, and myself, had similar cause to be grateful to her. On one occasion the artist divided the receipts at a concert among the members of the orchestra which had accompanied her on tour.

In her Life the fact is briefly recorded that she sang at a concert given by me in Mannheim on December 7,1846 . Under what circumstances I was thus honoured is not stated. They may 
prove of interest, as furnishing a typical example of the artist's kindly disposition and generous nature.

In making her plans for an operatic tour in Germany, she arranged to give a single representation in Mannheim, singing in La Figlia del Regimento (her most popular rôle). The date fixed was December 6. Accidentally she discovered that my concert, or, rather, recital - for such it was-had been arranged for the following day. At this time I was in Stuttgart, where Madame Lind happened to be staying, and she at once sent for me, and expressed genuine regret that the two events were going to clash, adding a fear-a very reasonable one-that I might suffer pecuniarily from the performance at the Opera-house. I suggested the possibility of altering the date of my little concert, but she would not hear of my being put to any inconvenience of this kind. 'How would it be,' she added, to my intense surprise, 'if you were to include my name in your programme?' With what gratitude and pleasure I accepted this offer - as spontaneous as it was uncalled for-need not be told. When the magic name of Jenny Lind appeared in all the glory of large type in my programmes, the rush for tickets was, as can easily 
be imagined, phenomenal; and when the day of the concert-the most successful it has ever been my lot to give in Germany-arrived, excitement and interest in the event were increased tenfold by reason of the immense furore created by my 'star' on the previous night in her favourite character.

In striking contrast to this pleasant reminiscence, I might here recall the attitude many years later of a compatriote of Jenny Lind'sdistinguished in the musical world-whom I engaged for a tour of the English provinces, at fees which totalled up to something like $£_{3}$, 000. Unfortunately for me, this speculation turned out a disastrous failure-so much so that the other members of my party, with a kindness characteristic of the musical profession, proposed to my prima donna that they and she should give their services for me at my next London concert. Her reply was, 'Certainly not; if the venture had been a success, he would not have presented me with an additional cheque; therefore why should I sing for him for nothing because he has lost ?' Look upon this picture and on that!

To the immense sensation produced by Jenny Lind in London during the following summer, I have already referred. She was at that time com- 
monly spoken of as the 'Swedish Nightingale'no mean compliment, I might remark, to the race of warbling birds. When in this metropolis, the diva continued to show a friendly interest in my musical career. It was during that season (1 847) that the Dowager Queen Adelaide gave an evening concert at St. James's Palace, of which Madame Lind was the 'star,' the other vocalists being J. L. Gardoni and old Lablache. Madame Lind proposed me as pianist and accompanist for that interesting event, at which Queen Victoria and the Prince Consort were present. Never shall I forget that occasion, memorable for the gracious kindness of the Queen Dowager, and for the entertaining exuberance during the subsequent prandial proceedings of my friend Lablache, whose unfailing cheerfulness and rich fund of humorous talk at all times proved one of his most engaging traits. 


\section{CHAPTER XIII.}

\section{A BATCH OF CELEBRITIES.}

M. W. Balfe-Les Quatre Fils de Haymon-Madame DulckenMoscheles-Julius Benedict-Ferdinand David-Madame Dulcken's concerts and parties-An incident at one of the latter - A luncheon to Mendelssohn - Benedict's hospitality - Lady Benedict - A happy event - Royal compliments thereon-Moscheles and the composer of Elijah-The former's farewell recital-Camilla PleyelReturn of the 'Wanderer.'

Frov Mannheim I returned to London, where I made the acquaintance of Balfe, then at the zenith of his fame. I had previously heard in Germany his opera Les Quatre Fils de Haymon, originally written for Paris. In the Fatherland it achieved as great a popularity as did the same composer's Bohemian Girl in this country. In London I became very intimate with Balfe, and remained his close friend until his death.*

* His daughter Victorine, an exceedingly handsome girl possessing a beautiful voice, made her début in 1859 in $L a$ 
At the time I am speaking of ( 1845 ), the three most prominent musicians in London were Madame Dulcken, Moscheles, and Julius Benedict. All three entertained in a style not known at the present day in the musical profession. That is to say, they held weekly receptions on a large scale, at which 'society,' musicians, painters, and literary people of distinction, were wont to foregather. More charming and agreeable hostesses than Madame Dulcken, Madame Moscheles, and Mrs. Benedict, it has never been my good fortune to meet.

A highly accomplished lady was Madame Dulcken. Coming of a very musical stock, she was the sister of that celebrated violinist, Ferdinand David, for whom Mendelssohn wrote his Violin concerto, and was herself a very gifted pianist. Her annual concert was always one of the events of the season, all the 'stars' of the first magnitude being in the habit of assisting thereat. These entertainments were, moreover, thoroughly cosmopolitan, artists of every nationality being at all times ready to assist the talented benéficiaire. A notable characteristic of the latter was her remarkable wit, for which she enjoyed quite a far-

Sonnambula. She afterwards became Lady Crampton, and subsequently Duchesse de Friaz. 
reaching reputation. Occasionally, be it confessed, the lady was amusing at the expense of other people, but so good-natured and kindhearted was she, that they invariably pardoned any remark she made, no matter how satirical.

I remember at one of her parties there were present, among other artists, my friend Pischek, Schulhoff (then a favourite pianist), and a gentleman whom I will designate as Mr. P_ and whose capacity for 'drawing the long bow' was both extensive and peculiar. The three were chatting together, when the hostess, approaching them, exclaimed:

'Now, Pischek, sing us something; Schulhoff, play us something; $\mathrm{P} \longrightarrow$, lügen sie uns etwas for' (tell us a few fibs).

In I 847 Jenny Lind sang at one of Madame Dulcken's receptions, and about this time I recollect the gracious hostess giving a luncheonparty in honour of Mendelssohn, whose acquaintance I then had the pleasure of making. It was only in the previous September that he had produced his immortal Elijah* at Birmingham.

* I may recall being greatly impressed by Staudigl's rendering of the principal part in that evergreen work, but he was, in my opinion, surpassed in it a few years later by Karl Formes, who, nevertheless, was inferior as an all-round artist to Staudigl. His conception of that particular part, however, was more 
At Benedict's house one met about the same society as at Madame Dulcken's. It was a strange admixture-albeit representative-of the world of fashion and of Bohemia, the brightest and best side of the latter being there found. Benedict's wife, an Italian by birth, was a most accomplished and amiable woman.

While writing of Benedict, than whom I have known few more industrious and versatile musicians, let me say that some years after the death of his wife he married Miss Forty, who, despite her name, was young, and possessed, moreover, considerable personal attractions. It may be interesting to recall that this lady had travelled all the way from India for the purpose of studying music under Benedict. Their union was blessed with one child - a boy-on the day of whose birth there happened to be a dinner at the Marlborough Club, at which the Duke of Edinburgh presided. The party included Sir Michael Costa and Sir Arthur Sullivan, the last-mentioned bearing the news of what had happened at No. 2,

dramatic. But in later years both these singers were completely eclipsed in Elijah by an Englishman in the person of my old friend Charles Santley. The ring of his marvellous voice, his perfect phrasing, and his true devotional feeling, placed him head and shoulders above all his predecessors within my recollection. 
Manchester Square (Benedict's house). On hearing it, His Royal Highness at once stood up and proposed the health of Sir Julius and Lady Benedict and the new-born baby. The Prince of Wales wrote a most gracious letter of congratulation to the happy pair, offering himself as godfather.

The season of I 846 was the last of Moscheles' residence in London. After many years' stay in this country, where he made a host of friends, he yielded to the solicitations of Mendelssohn, who had an enormous admiration for his talent, and accepted the position of professor at the Leipsic Conservatoire, of which institution the composer of the Hymn of Praise was the President. Moscheles gave four farewell recitals and a valedictory concert, when his friends assembled in force to wish him God-speed. Amongst other things, Moscheles played on that occasion a concerto by Bach, for pianoforte and two flutes, and a new sonata of his own à quatre mains, in the interpretation of which he was joined by Madame Camilla Pleyel. A great executant was Moscheles, and a most gifted composer-almost, I might say, a classic. Madame Moscheles was one of the most charming, gifted, and remarkable women it has ever been my good fortune to know. Singularly prepossess- 
ing even in middle-life, she was in later years one of the most interesting-looking old ladies imaginable. When her husband died, it was touching to observe how at all times she kept his memory green. Hardly ever did she converse with anybody on the subject of music. without recalling his playing and his compositions.*

Finally, to pass over a number of years, I have a vivid recollection of the distinguished artist returning to England in $\mathrm{I} 86 \mathrm{I}$, and playing at a Philharmonic concert his fine Concerto in $G$ minor. Never shall I forget the extraordinary enthusiasm with which his old friends and admirers welcomed him back. Moscheles, who had not been heard in this country for fifteen years, was then sixty-seven years of age. But time had dealt gently with this artist, and the vigour and energy of his playing on that occasion was simply astounding.

* At the present time it is my privilege to boast the friendship of the gifted son, Felix Moscheles, well known in the artistic world as a painter of considerable attainments, and who was Mendelssohn's godchild. 


\section{CHAPTER XIV.}

\section{LABLACHE.}

His Don Pasquale-A cab incident-A famous quartetteLablache in private life-His sense of humour-His singing of 'buffo' songs-Operatic artists and the incometax-Lablache's snuff-boxes-His son Frederic.

In the same season another artistic treat furnished me with many subsequent agreeable recollections. This was Lablache's inimitable and incomparable performance in Donizetti's delightful comic opera, Don Pasquale. Immense genius, in my opinion, characterized his assumption of that part. It constituted the finest comedy-acting imaginableso humorous, and, above all, so natural. Indeed, one almost forgot that he was on the stage, and felt (at least I did) inclined to shake hands with him whenever he came on, and exclaim, 'How do you do, Signor Lablache ?'*

* I only knew one other actor who was sufficiently natural to produce a like impression upon me, and that was Charles Mathews. 
Lablache had a singularly fine face and head, but his corpulence was enormous. It never, however, prevented him being most graceful in all his movements, and, strange to say, he had the tiniest feet. His obesity enabled him to appear to the greater advantage in such parts as Don Pasquale, in which rôle especially he evoked a vast amount of hilarity, as in the scene, for instance, in which he indulged in a good five minutes' pantomime in his frantic efforts to get possession of a letter which the wife, Norina, had dropped. The 'business ' brought to bear on this incident was mirth-provoking in the highest degree, and the effect quite indescribable.

Apropos of the singer's extraordinary corpulence, I remember an amusing thing happening. On one occasion, driving to Her Majesty's Theatre in a very rickety and prehistoric-looking cab, the licensing of which constituted a disgrace to the authorities, the bottom of the vehicle gave way, and poor Lablache, his feet dangling above the ground, had perforce to run some little distance before the driver of the patriarchal 'growler,' hearing the unlucky occupant's cries for assistance, became alive to the situation and pulled up. The victim afterwards narrated this accident to me with great gusto, turning the joke 
against himself, and indulging in no anathema at the expense of the Jehu, whose property had 'gone under' at so unpropitious a moment.

I never missed an opportunity of seeing Lablache in Don Pasquale, but after his retirement that opera possessed no attractions for me. With the famous basso there used to appear in it Grisi, Mario, and Tamburini, making an incomparable quartette, all being as great as players as they, were unrivalled as singers. It always struck me as remarkable, in connection with this performance, how naturally the artists I have named disported themselves in every-day costume. Nowadays, of course, operatic performers are not called upon to don ordinary dress, and it is difficult to conceive members of the Covent Garden company strutting about that vast stage in modern apparel.

In private life Lablache was singularly fascinating, full of wit and bonhomie, and always cheery and good-humoured. He would talk for hours in a bright, amusing vein, and I cannot recall ever having seen him ruffled.

I forgot, in writing of Lablache's artistic gifts, that his singing of 'buffo' songs was absolutely different from anything of the kind one hears nowadays, either in this country or abroad. 
Indeed, that style of singing, as exemplified by Lablache's unique rendering of Rossini's Tarantella, may almost be said to have become obsolete.

Apropos of the 'last of the great buffos,' I remember an amusing story. One year (I forget which) the Income-tax Commissioners sent to the Italian Opera House 'demand ' papers to be filled in by all the principal artists engaged for the season. Never before had foreign singers who were only on a few weeks' visit to this country been importuned in this fashion; nor, to my knowledge, has the experiment been repeated. It so happened that Lablache had quitted London at the time that these precious documents were left at the theatre, and his paper only reached him some months later in Paris, at the very moment when he was on the point of starting for England. At first he was completely mystified by the terms of the official blue paper, but when, at length, he had mastered its contents, he was so indignant that he forthwith abandoned his projected journey, and, what is more, he has never been seen or heard in England since. That income-tax paper was too much for him.

Incidentally I might allude to Lablache's son Frederic, an excellent artist, most serviceable in 
opera, popular on the concert-platform, and, after his retirement from public life, much sought after as a professor of singing. His thorough amiability, in which respect he was a real chip of the old block, endeared him to a large circle of friends.

And to return for a moment to Lablache the elder, he had, among other peculiarities, an extraordinary affection for snuff-boxes. Of these he boasted a remarkable collection of every shape, size, and make, having a different one for use on every day in the year. And, singular to relate, they were all presents, he having once imparted to me, with an air of humorous mystery, that he had never invested a halfpenny of his savings in a snuff-box. The one he valued most was a gift from Her Majesty the Queen. Which fact reminds me that, with the exception of Mendelssohn, Jenny Lind, and, in recent times, Madame Albani, no artist has ever been such a favourite of our gracious Sovereign as was the brilliant and amiable friend of whom I have been writing. 


\section{CHAPTER XV.}

JULLIEN.

His remarkable individuality-Promenade programmes-Good value for money-British Army Quadrilles-Jullien as a conductor-What he did for music-Some famous instrumentalists - A season of English opera-Dorus Gras-Sims Reeves-Whitford Jones-Hector BerliozBalfe's Maid of Honour-Martha-A famous old lyricJullien's fate as operatic manager and composer-A short-lived opera-Anna Zerr-Jullien's detractors.

At about the time that Lablache was charming English musicians, a familiar and popular figure in London was that of the famous Jullien, than whom, probably, no French visitor in our midst has ever obtained a firmer hold upon all classes. Save in his palmy days, Sims Reeves, and, at the present time, Henry Irving, possibly no man figuring in the artistic world has been more wirlely known as an 'individuality' than the originator of the promenade concerts. I recollect about this period riding on the top of a 'bus - a mode of locomotion very much to my liking when I first 
came to London-and hearing the conductor shout out to his driver that Jullien (pronounced something like 'Jolly un') was passing on 'the near side.' I had not the least idea what 'near side' was intended to imply, nor did I gather the name of the distinguished pedestrian; but my neighbour on the 'knife-board ' enlightened me in the matter, and I confess to being amazed at the instant recognition of the wayfarer at the hands of a non-musical 'conductor.'

For the benefit of the present generation, who take their pleasures so sadly, let me endeavour to convey some idea of the extraordinary value the worthy and esteemed host was wont to give his guests for their money. His programmes, as a rule, would consist of popular-I may say very popular-overtures; solos by renowned artists of the first rank, such as Bottesini, Vieuxtemps, Sivori, or Wieniawski; a couple of songs by a favourite vocalist; and dance music composed by the conductor himself. His 'descriptive' compositions, notably the famous British Army and Navy Quadrilles (still played on festive occasions at the Crystal Palace), are too well known to need description; but apropos of their performance in the old days, I may say that, to me, their rendering by massed military bands was extremely novel 
and interesting, while the accompanying marchpast, in doubtless capital form, of soldiers and sailors (this was, of course, at the National Theatre) impressed me mightily, albeit I confess the proceeding struck me as peculiar.

Jullien's conducting, to say nothing of his appearance, was so amusing and eccentric that many people, to my knowledge, attended these concerts more for the sake of watching his 'beat' than hearing the music. But whatever faults, on artistic grounds, may have been found with the composer of the British Army Quadrilles, it should at least be placed to his credit that, by including in his programme, as he invariably did, a movement of a Beethoven symphony or some other classic, he was the means of popularizing good music amongst a class of the public who never had an opportunity of becoming acquainted with master-pieces. Not only in London was this the case, but in the provinces, where, at the conclusion of the Metropolitan season, Jullien was wont to take a small orchestra, giving concerts all over the country.

He was also the means of introducing to public notice a number of instrumentalists, unknown at that time, but all of whom in after-years achieved celebrity. Among others I may mention the following : Koenig (the best cornet-à-piston player ever heard), Lazarus (the well-known clarinettist, whose 
death not long since was keenly regretted), Howell and Bottesini (contrabassi), Raumann (bassoon), Collinet (flageolet), Richardson (flute), Lavigne (oboe), Hughes (euphonium), and Cioffi (trombone).

A singularly enterprising and untiring man was Jullien. Thus, in 1847 , in addition to his other ventures, he undertook the management of English opera at Drury Lane. If ever success was deserved, it was here in poor Jullien's case. He opened with Lucia, engaging for the principal rôles Dorus Gras (a delightful French singer). Sims Reeves (who had made one solitary appearance the previous year), and Whitford Jones. Hector Berlioz was the conductor.

An interesting event in that season was the production of an opera specially composed by Balfe. It was entitled The Maid of Honour, and was based on the same subject as Flotow's popular, but now seldom performed, Martha. I am bound to say, however, that the opera pleased me but little; nor did the public take kindly to it. The only 'number,' so far as I recollect, that was an instantaneous popular success was the melodious tenor song In this Old Chair my Father sat. This was magnificently rendered by Sims Reeves, and created something like a furore. But with English opera Jullien shared the fate of many theatrical managers before and after him. The 
loss was very heavy, but the victim of a fickle public enjoyed at least the consolation-maybe a doubtful one-that all true lovers of music sincerely sympathized with him. They had gained artistically where he had lost pecuniarily.

Somewhere in the fifties Jullien blossomed out as the composer of an Italian opera. The story, founded on the subject of Peter the Great, had much in common with Meyerbeer's L'Etoile du Nord; but the same, alas! cannot be said of the score, the crude and unworkmanlike character of which provoked at the time a good deal of chaff at the expense of the luckless composer, the banter being for the most part based on the obvious truth that to write quadrilles is one thing-to compose an opera, another.

Peter the Great saw the light (promptly extinguished) on the stage of Covent Garden, and it had the advantage of an excellent and attractive cast. Anna Zerr (a delightful singer from Vienna) was the heroine, and did wonders with the music allotted to her.

Jullien, let me add, was an exceedingly kindhearted fellow, and although by many musicians considered a charlatan, he was, in my opinion, a true lover of his art. But be this as it may, his death was deplored by all who knew him. 


\section{[91]}

\section{CHAPTER XVI. \\ EVENTS IN 1847 .}

A record season-Lind and Gardoni-Rival opera-housesCovent Garden enters the lists-Costa and his orchestra migrate thither-Balfe succeeds him at Her Majesty'sThe pas de quatre-Alboni's début-Mendelssohn at Exeter Hall-Charlotte Dolby's first triumph-WillmerSchulhoff-His private life - A romance-Rare fidelity -A cheerful prognostication - 'Mistaken treatment'Schulhoff, Willmer and Benedict my co-performersHenry Russell-Cheer Boy's Cheer.

THE musical season of 1847 was one of very great interest. Jenny Lind, as I have already said, took London by storm, although some share in the honours won at Her Majesty's Opera House fell to Gardoni, a handsome young tenor, who retained during many years the popularity which he had secured in La Favorita on the occasion of his first appearance.

A memorable event of the year was the inauguration of a rival Italian Opera at Covent 
Garden Theatre, with Grisi, Persiani (a celebrated soprano, who, however, never enchanted me), Mario, Tamburini, Marini, and a host of other singers, under the conductorship of Costa, who was followed in his migration by the entire orchestra of the old house. Balfe, who succeeded him there, had of course to get together a fresh band of instrumentalists, at that time no easy matter. Lablache and his son Frederic remained staunch to 'Her Majesty's' Opera, where the ballet continued to be of resplendent quality. Taglioni, Cerito, Carlotta Grisi (no relation of the great singer), and Rosati, danced the celebrated pas de quatre in a style to which the present generation is a stranger. Their performance was an exquisite poem in motion, the remembrance of which forces upon one the regretful reflection that real dancing is a lost art.

At Covent Garden Alboni, the great contralto, made her début in Semiramide. The next day her fame was upon every tongue; but even she could not save the fortunes of the new venture, for the counter-attraction of Jenny Lind at the rival house was irresistible. And yet Alboni has been surpassed neither in voice nor in art (Adelina Patti alone at the present day can rival her rendering of Rossini's music). She had, I may recall, a 
particularly beautiful head, but was enormously corpulent. After her marriage and subsequent settlement in Paris, she sang occasionally at Rossini's receptions and at charity concerts, her voice remaining exquisite throughout her declining years. Ever charitable, she left her large fortune to be devoted to the poor of Paris.

I 847 was also a Mendelssohn season. The lamented composer conducted his oratorio Elijah (written for the Birmingham Festival) at Exeter Hall in the presence of the Queen and the Prince Consort, and it at once took its place beside the Messiah of Handel as a monumental work destined to live for all time. The performance was the occasion of the first triumph of Charlotte Dolby, a charming young English contralto, whose singing of the aria, O rest in the Lord, has never been surpassed. Her vocalization had previously won the composer's admiration at Leipsic. Mendelssohn also conducted at one of the Philharmonic concerts his Midsummer Night's Dream music and Scotch Symphony, and also exhibited his skill as a virtuoso in Beethoven's pianoforte Concerto in $G$. His rendering of the work was masterly, and the cadenzas which he improvised were nothing short of superb.

Among the musical lights of this memorable 
summer were two pianists: the first a Dane, by name Robert Willmer, who had made a great success in Germany; the second being my old schoolfellow Julius Schulhoff, who brought with him a great reputation from Paris. Schulhoff had already written much for the pianoforte, his works being popular with almost every artist, professional and amateur. His playing was most refined and graceful, his compositions fresh, melodious, and always artistically written. His Chant du Berger-in its way a gem-he wrote for and dedicated to me.

In private life Schulhoff was so genial, humorous, and good-natured, that he soon gathered around him a host of friends. When quite young, and still a fellow-student of mine under Tomaschek at Prague, he formed an attachment to a young girl of good family, but, like himself, poor. Truly, there was little prospect of their love being cemented by union, and an offer presenting itself from a very wealthy suitor, the solicitations of the lady's family prevailed with her. Her husband proved a most estimable gentleman, with whom she lived happily for twenty-five years, when he died, leaving her with two daughters* and a large fortune. The fidelity

* One of the daughters married the pianist Wieniawski, brother of the celebrated violinist of that name. On the 
of her old lover, who had remained single, was then rewarded with her hand, and Monsieur and Madame Schulhoff now lead a life full of felicity, passing the winter generally in Rome.

An anecdote of my old friend is worth recalling here. Being in a bad state of health, Schulhoff consulted a well-known Wiesbaden doctor, and insisted on learning the probable length of existence yet remaining to him. The physician, unwilling at first, finally gave in to his entreaties, and told him that with care he might live another twelve months. Schulhoff then went to Italy, where his health rapidly improved, until at length it was completely restored. Returning some years later to Wiesbaden, Schulhoff sought out the health-prophet, and acquainted him with the falsity of his prediction; but, to his great amusement, the physician coolly replied: "Well, all I can say is that the doctors in Italy must have made a great mistake in their treatment.'

I had the pleasure during the season of playing with Schulhoff, Willmer, and Benedict, a pianoforte piece for four performers, written at the request of the last-named, by Moscheles for his annual concert. The work (entitled Les Con-

wedding-day the lucky bride received from her mother a dot of $£ 20,000$. 
trasts) met with considerable success, and was a noteworthy contribution to the compositions of a fruitful season.

My musical record of 1847 would be incomplete without some mention of that most popular composer and singer, Henry Russell, who as an entertainer stood in his time unrivalled. His popularity at that time was so great that, wherever he went, the largest available hall had to be engaged. I used to hear him occasionally at Drury Lane Theatre, where he held vast audiences spellbound. I can only mention here a very few of his most popular descriptive songs, such as Cheer, Boys, Cheer, The Ship on Fire, and The Maniac. These he would intersperse with stories told in his own inimitable way, until he began a fresh song with an entrain, a fire and an energy so infectious as to rouse his audience to the point of joining enthusiastically in the chorus. So catching were his melodies, that they were heard in every street, either whistled by boys or played upon bands and organs. Nevertheless they were thoroughly musicianly in character.

In society Russell was equally entertaining, and I can call to mind many pleasant hours spent at the house of our mutual friend Mr. J. M. Levy, in the company of this jovial, kind-hearted man. 
Two years ago he conducted some of his works at a Covent Garden promenade concert, and was received with an enthusiasm which must have proved to him how well he was still remembered after long years of retirement. $\mathrm{He}$ is now over eighty years of age, albeit his enthusiasm for his art, and his energy and vigour in its service, is astonishingly youthful. 


\section{CHAPTER XVII.}

BRIGHTON HALF A CENTURY AGO.

First visit to London-by-the-Sea-The Brighton season in I 847-No 'trippers'-A fashionable August-Frederick Wright-Jenny Lind at the Town-hall-Colossal receipts -Then and now-George IV.'s Pavilion-The DomeVisit of operatic artists-Frederick Beale-Music in the Square-John Parry-A dearth of amusements - The Brighton Theatre-Mrs. H. Nye-Chart-My pianoforte recitals-News of Mendelssohn's death-Painful incident -J. W. Davison - 'Music dead '-Mrs. Sala-George Augustus Sala.'

IT was in the autumn of I 847 that, following the example of a great many Londoners, I betook myself to Brighton-at that period in the zenith of its popularity. I was delighted with Brighton, and the town, I may say, took very kindly to me, for I soon made as many friends, and boasted as many pupils, in London-by-the-Sea as in the great Metropolis itself.

With the exception of a night spent in Ostendafter a passage across the Channel that made any 
appreciation of the pretty Belgian town wellnigh impossible for those who had left the steamer-I had never passed any time by the seaside, and my visit to the marine resort beloved in days of yore by George IV. possessed, therefore, the charm of novelty.

It so happened that the Brighton season of I 847 was a very brilliant one from every point of view, and not less so musically than socially. I might here mention that at the time of which I am writing the fashionable period in Brighton commenced about the beginning of August-now a month of 'trippers' so far as that place is concerned-and lasted till the end of October, when everybody who was anybody forsook its pleasures and sought their own homes or other climes.

Let the following fact speak for the social character of those who made the popular wateringplace their happy hunting-ground half a century ago. In 1847 , the late Frederick Wright, a local concert-giver, was able to pay Jenny Lind a fee of $£ 500$, and after settling with the artists who supported her, and defraying the other incidental expenses, pocket a sum equal to that given to the diva. And yet the concert was held in the Town-hall, a building that only accommodated some six hundred people. The highest-priced 
seats, I should mention, were three guineas, and the lowest one guinea, and yet not a vacant place was to be seen in the hall on that memorable occasion. I should like to note the expression on the countenances of my friends the Brighton public at the present day were I to announce a concert for admission to which I charged half those figures. But in those early days the Dome of George IV.'s disused and ornate pavilion had not been dedicated to its present purposethat of a concert-hall-and there was only the one inadequate building I have referred to in which such entertainments could be given. Hence, whenever any great expense was incurred, the necessity for the high prices that ruled.

But there was very little in the way of music put forward at that time to amuse and edify visitors to what has been called the Queen of Watering-places. The principal musical event of the season, as I remember it then, was a flying visit from the members of the Royal Italian Opera Company, who appeared, under the auspices of Frederick Beale, at one concert, or at the most two. So far as I can recall, there was no other undertaking of the kind calculated to excite the interest of visitors, albeit the latter used to foregather in large numbers on two afternoons every 
week in Regency Square, to listen to the strains of the military band of whatever regiment happened to be stationed in the town at the time. I should not forget, however, to make mention of the recital given annually by Madame Dulcken, and the entertainments with which the inimitable John Parry was wont occasionally to delight his many admirers.

Theatrically speaking Brighton was not much better off, in the forties, than it was musically. Those who took up their abode in the Sussex town for the season did not regard the very diminutive theatre that then ministered to the wants of lovers of the play as a sufficiently fashionable resort to warrant their supporting the local drama, and in this, perhaps, they were right. Only at rare intervals did a histrionic 'star' from L.ondon tread the local boards-a circumstance that may well astonish Brightonians who date their theatrical reminiscences from the time when Mrs. Nye-Chart-a singularly astute manageress and most amiable and kind-hearted lady-took in hand the interests of Brighton playgoers, and raised its theatre to a high position among provincial playhouses. And let me here say that the death, some few years back, of "Nellie" NyeChart-as she was known to all her friends-fell 
as a personal blow on every resident in the town, and many visitors besides. In countless ways had she endeared herself to them, and to this day they hold her memory green.

During my first stay in the town I was induced to give three pianoforte recitals, and I also gave a concert, for which I engaged, among other singers of the Italian Opera, that famous contralto, Madame Alboni. Among the vocalists who assisted me at my recitals, was Charlotte Dolby. Never can I forget an event that cast a gloom over my second recital. The sad tidings had just come of Mendelssohn's death. Miss Dolby, who sang for me, was so overcome, as well she might be, that she almost broke down in one of the master's songs. I played, in memoriam, one of his Lieder ohne Worte, the one in $\mathrm{E}$ minor, Book V., No. 3 (which the composer may have intended for a funeral march), and the whole audience remained standing. A few days later I chanced to be dining with J. W. Davison, who, speaking of Mendelssohn's demise, said, 'Now music is dead,' an exaggerated sentiment, doubtless, but the mere mention of which will convey, as no words of mine could, the feeling of calamity which for a time took possession of English musicians. I certainly remember no other instance in which the 
loss of an artist not residing in this country has been so deeply felt throughout the kingdom.

Among the musicians then resident in Brighton was Madame Sala, mother of that exceedingly brilliant and popular journalist, the late George Augustus Sala. She had formerly been well known as a soprano singer, and was, when I met her, an extremely amiable lady, possessed of no mean conversational ability. Mrs. Sala was good enough to reckon me among her best friends, honouring me with her confidence so far that, up to the time of her death, I invariably advised and assisted her in her annual concert. Some few years ago (during my residence in Brighton) I heard of George Augustus Sala's arrival there. Calling on him without delay, I was informed that he was out, and accordingly left my card. I had only taken a few steps, however, when the servant, running after me, called me back to the house. Sala was at home; but, as he told me in greeting me, his 'copy' being due at the Daily Telegraph and the Illustrated London Nerus, he was obliged to deny himself to everyone. Having seen my card, however, he felt he could not send away one who had been kind to his mother. So filial an action is too likely to be appreciated for me to leave it unrecorded. 


\section{CHAPTER XVIII.}

$A N$ EPOCH-MAKING YEAR- 1848.

Revolution-An artistic 'invasion of England'-Paris in London-Theatrical jealousy-Charles Hallé-His reputation as a classical pianist-Makes England his homeExalted standard of taste-Phenomenal memory-His removal to Manchester--What London lost-Advantage of permanent orchestras-Manchester Royal College of Music-Hector Berlioz and the Marseillaise-Johann Strauss-His band at my concert-Weber's ConcertstïckJetty Treffz-Reichardt-Sophy Cruvelli-I hear Chopin at Madame Sartoris'-Impressions-Poetry in sound-The Valse in D flat-Presage of Death-Mario's songs.

Christmas found me in London again in time to witness the extraordinary influx of foreign artists who in February, 1848 , were driven by the Revolution to seek refuge in this country. The event, temporarily disastrous for many of the visitors, must be looked upon as a distinct element in what I may, perhaps, be allowed to call the musical evangelization of England.

London experienced a kind of artistic invasion. 
Musicians, vocal and instrumental, painters, actors, artists of every sort and degree-famous, good, bad, indifferent-who did not think their residence in Paris, or, indeed, anywhere on the Continent, a matter of safety, flocked to the centre of commerce, and for the time invested one quarter of it, at any rate, with quite a new aspect.

Walking in Regent Street, or Bond Street, or more particularly in the neighbourhood of Leicester Square, one might, without any great stretch of imagination, have imagined one's self in Paris. Many theatres, also, were occupied by foreign companies. We had a French opera as well as the usual Italian, two French plays, a French circus, and other Parisian entertainments. But at last, when the Théâtre Historique from Paris essayed a performance of A. Dumas' Monte Cristo, English jealousy became aroused, and the disturbance was so great that the first act was given practically in dumb show, until, as it became evident that the performance could not proceed, the curtain was lowered.

Among the musicians who, so to speak, invaded London during this year of perturbation were Kalkbrenner, Thalberg, Schulhoff, Berlioz, Ernst, Joachim, Chopin, Johann Strauss the elder (with his Viennese orchestra), Reichardt, Jetty Treffz, 
and last, but very far from least, Charles Halle, whose advent proved to be for the unspeakable advantage of musical progress in England.

I remember, as though it were but yesterday, a certain Sunday evening when this talented young man and his wife, a most interesting woman, were among a pleasant party assembled at the house of Madame Dulcken. The great reputation as a classical pianist which had preceded him from Paris was fully sustained that evening, his performance delighting us all. His complete mastery of the instrument soon established him as a favourite, his success ultimately being so great as to induce him to relinquish all idea of a return to Paris. England became thenceforward his home and the scene, during the nearly fifty years that have since elapsed, of ceaseless yet unobtrusive activity. Determined from the first never to pander to the taste of the multitude, no one has done more than he to raise the standard of musical taste among us. In no single instance has he been known to play anything but the best music, and that in so refined a manner as to call forth an initial exercise of the appreciative faculty in the comparatively unlearned, and to quicken it where it had already begun to work. Without stooping to astonish by mere 
virtuosity, he has ever interpreted classical works in the true classical style.

His memory even in those days was at once so happy and of such vast capacity, and his knowledge of everything good in music so extensive, that at a moment's notice Charles Hallé was able to sit down and play any composition of Bach, of Beethoven, of Chopin, or of any of the masters who flourished in the sweep of time between them. I myself heard him play from memory in the course of a cycle of eight performances, given during a single season, the whole of Beethoven's thirty-two sonatas. ${ }^{*}$

Occasionally asked at the last moment to take the place of some other pianist, Hallé would never allow the programme to be altered, but was always ready to play the pieces originally selected, a fact which can only be rightly appreciated by those who go to a concert to hear a particular work with which they desire to be better acquainted, and not simply to pass an afternoon or evening in witnessing the gymnastic performances of muscular virtuosi.

A few years later Charles Hallé migrated to Manchester, which thenceforth became the field

* This feat Charles Hallé has often repeated, playing alternately with the Beethoven sonatas the forty-eight preludes and fugues of Bach's Wohltemperirte Klavier. 
of the chief labours of a well-filled life. What London lost may now be seen in the fact that in a few years Manchester became far and away the most musical city in England. Hallé not only instituted an annual series of twenty concerts during the winter season, but succeeded in getting together the first permanent provincial orchestra in the country, being thoroughly persuaded that the excellence of ensemble to be attained by a band of experts accustomed always to play together is a very different thing to the performance of a more or less heterogeneous body of instrumentalists, hastily gathered from London and other available centres, such as that with which Manchester had been obliged hitherto to content itself.

One may, perhaps, be permitted to wonder that so good an example has not been more extensively followed in other large centres. The want of 'permanent' orchestras is due, assuredly, to no deficiency in talent or training; it must, I suppose, be ascribed to the absence of organizing skill, and points, therefore, to Hallé's success in this direction as something almost phenomenal. Sir Charles Hallés zeal has not abated with the growth of years. Under his guiding hand the Manchester Royal College of Music has been 
established, and is doing good work. His energy and perseverance is even now, at the age of seventy-six, simply astounding.*

Hector Berlioz was also among those whose acquaintance I made in this year. I remember walking home with him one Sunday evening, and chatting on the way a good deal about the French Revolution. In connection with that subject the Marseillaise was mentioned, and incidentally Berlioz remarked how odd it was that in Eugland the street bands should play a portion of it in the minor key as follows :

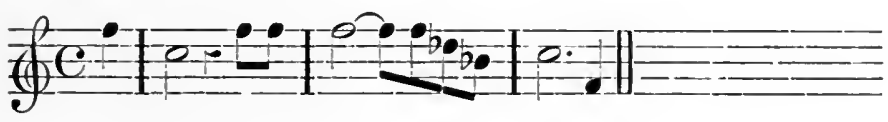

The D flat as then played in England is in the original D natural.

Johann Strauss the elder brought with him to London, as I have said, his famous band from Vienna, in which city I had known him well. He very generously allowed his orchestra to play at my 'grand' morning concert-I have never been able to discover why concerts should be called 'grand'-at the Hanover Square Rooms. Such a

* The above remarks relative to Sir Charles Hallé were written a short time before the death of that lamented musician.-AUTHOR. 
substantial addition to my programme was a great attraction in itself, and enabled me, besides, to play Weber's Concertstiick with orchestral accompaniments. This was the first time I had played this celebrated Concertstiick in public. The last, I may mention, was in August, 1895, when I assisted at a concert given in Homburg for the benefit of the poor.

Strauss died in the course of the following year, to the great consternation of the Viennese, who honoured with a popularity altogether exceptional 'the king of all valse composers,' as they proudly loved to call him. He left three sons to perpetuate his memory-Johann, the composer of many charming operettas, notably Fledermaus, and most original valses; Joseph, who died on a concert tour in Russia ; and Edward, who brought the Strauss orchestra to the Imperial Institute this year (I 895), greatly to the delight of London music-lovers.

Among other artists who assisted me on the occasion I have mentioned were Jetty Treffz, an accomplished and most popular singer, who became the wife of Johann Strauss the younger; Ernst, Reichardt, ${ }^{*}$ and Jules Schulhoff. With

* Reichardt became a great favourite, some of his songs securing wide popularity, to mention only one, Thou art so Near, 
such an array of talent my concert proved so great a success that I repeated it annually until a very few years ago.

The season of $\mathrm{i} 8_{4} 8$ was further rendered memorable to me by the appearance, at Her Majesty's Theatre, of Sophy Cruvelli, whom I had missed hearing the previous year. Beautiful in person, she possessed a magnificent voice and quite a marvellous histrionic capacity, which she exhibited particularly in Beethoven's Fïdelio, reminding me much of Madame Schröder-Devrient, whom, best of all Fidelios, I had heard in Prague during the thirties. Sophy Cruvelli was very impulsive, and her performance appeared to lack repose; but she possessed undoubted genius, and would have made a success even greater than she actually did had not Jenny Lind carried everything before her at that time on the very same stage.

In the month of June, to my great and lasting delight, I had the privilege of hearing Chopin for the first and, alas! only time, at a recital which he gave at Madame Sartoris', in Eaton Place. Gladly I paid my guinea to listen to and admire that rare

and yet so Far. He sang with considerable taste and feeling. In the winter of 1867 he was my companion in a tour of vocal and pianoforte recitals through the provinces. 
and completely original genius. Were Chopin alive now, every seat would, I venture to affirm, sell for five guineas within two hours of the announcement of a recital by him. At that time, however, he was known to only a very limited number of music-lovers in this country. In Paris his annual concerts were anticipated with the keenest interest, and his compositions were already the delight of all the pianoforte-players in France and Germany ; and Mendelssohn, Schumann, and Liszt led the van of his admirers. Here in England his works were published by Wessel (the predecessor of Ashdown and Parry); but the sale was by no means large, and they were seldom taught. Teachers in those days, in selecting pieces for their pupils, limited themselves to standard classical works. Stephen Heller was easily understood, and his charming pieces were quite the rage among amateurs of the better sort, while ordinary strummers and their instructors mostly contented themselves with 'variations' (I was nearly saying 'aggravations') on favourite airs and ditties.

High were our anticipations as, coming early, we secured our seats (mine, I remember, was next to that of Madame Roche, Moscheles' eldest daughter), and awaited the arrival of the most 
poetical of composers. The room was not large, but it was made to accommodate on that eventful afternoon an audience of 140 or 150 persons. At one end of the apartment, on a slightly raised platform, stood a splendid grand piano specially prepared by Messrs. Broadwood for Chopin's delicate touch. The impression made upon me by the mere appearance of this great artist I can never forget. His figure was attenuated to such a degree that he looked almost transparent ; indeed, so weak was he that at a party given about that time at Chorley's, when my wife was present, he had to be carried upstairs, being too feeble to walk. No sooner, however, did his supple fingers begin to sweep the keyboard, than it was evident that a revelation of refined and poetical playing awaited us. His wondrous touch, the perfect finish of his execution, I can only suggest. Let me merely sáy that the performance was to me the most perfect example of poetry in sound which ever greeted my ears. Among other original compositions he played several studies and mazurkas, his Berceuse (then unknown to me), and his Valse in $D$ fat. This last was still in manuscript, but so many inquiries for it followed Chopin's recital, that Messrs. Cramer, Beale and Co., who had purchased the copyright, 
were obliged to hurry on its publication, and it actually appeared two days after the manuscript left the composer's hands. Mario sang, in the intervals of the pianoforte pieces, Beethoven's penitential song and Spirto gentil from La Favorita. He looked extremely handsome in his velvet coat, presenting a strong contrast to the deathlike appearance of the great pianist, and singing as he alone could sing. The occasion was not altogether without a certain gloom.* Everyone felt that the genius who held us spellbound would not long be spared to the world. Poor Chopin! he was in the last stage of consumption, and death claimed him in the following year.

* The visitor to Paris, driving fron the Place de la Madeleine along the Boulevard des Italiens, the Place Royale, and past the Odéon, reaches the right side of the famous cemetery of Père la Chaise. Entering the gate and walking up the hill, he passes the splendid mausoleum of Rossini, simply inscribed in letters of gold with the name of the maestro. Higher up, slightly to the left, is the Musicians' Corner, where, conspicuous among many monuments, rises an immense column marking the spot where Cherubini lies, close to Hérold and Boielldieu. Another turn brings one to the resting-place of Chopin and the white marble statue which commemorates him. This beautiful monument bears the inscription: 'Frederick Chopin. Erected by his friends.' Two steps to the left, and one is confronted with the face which is so perfect a likeness that the composer seems to smile and say, 'Bon jour, mon ami.' He sleeps, but his works will live for ever. Hard by is the grave of Heinrich Heine. 


\section{CHAPTER XIX.}

A LUSTRUM OF MUSIC-1849-1854.

Henrietta Sonntag-Her reappearance-The Echo SongHer return to the stage-Mainly due to Thalberg-Her death in America-A contrast-Pasta's rentrée-'Three compatriots-Dreyschock's concert-The effect of his piece for the left hand on one of the audience-A 'strange, courteous gentleman'-Thalberg's Florinda-A dull libretto - National concerts-Ernst Pauer-Madame Pleyel-IVilhelmina Claus-Mrs. Anderson and Madame Puzzi-I play at the Birmingham Festival, $185^{2}$, and give three concerts in Vienna-My mother's death-My marriage in 1854 .

In the musical world the year I 849 was marked by an event of the first importance, namely, the reappearance on the operatic stage of the renowned Henrietta Sonntag (the Countess Rossi), wife of the Sardinian Ambassador in Berlin, after a period of retirement which had lasted more than twenty years. The story of her former triumphs in the twenties, when I was still a boy, was quite familiar to me, and I had heard as much of her 
beauty as of her matchless voice and execution. I shared, therefore, the curiosity and general excitement with which her advent at Her Majesty's Theatre was looked forward to; but I was not without misgivings, as she was past middle age, and I doubted, not unreasonably, whether she would realize the high ideals which the frequent hearing of Jenny Lind and other operatic luminaries had helped me to form.

But as soon as she came on the stage to play the part of Linda di Chamounix the common anxiety was set at rest. Sonntag looked about thirty at the outside, she had preserved her lovely figure, her voice was flute-like and fresh, her acting charming, and her execution perfect. The fact was that, although her voice had been allowed complete rest from public performances, she had never let a day pass without exercising it in private. In the course of the next three years I enjoyed many opportunities of hearing her both on the stage and on the concert platform. She appeared in several operas, including Don Pasquale and the Nozze di Figaro; and her concert performances included the now celebrated Echo Song, written for her by Eckert, her friend and accompanist. She also made a great sensation in Rode's Air and Variations, a composition written originally 
for the violin, which presented no difficulties to her, for she warbled the most intricate passages with astonishing ease. Her rentrée was mainly due to the persuasions of Thalberg, by whose introduction also I became known to her. In private life she charmed all who came in contact with her by her fascinating manner. I saw her for the last time in Baden-Baden, a year before her death, which, occurring in 1852 , brought to a premature close a concert-tour in the United States.

A curious and instructive contrast to this happy reappearance of a long-retired artist was afforded in 1850 by the return to the stage of Pasta, in former days one of the greatest singers ever heard, who was prevailed upon to give a few performances at the opera. When the event was announced, great expectations were formed, and an eager welcome awaited an artist who had so greatly delighted the world years before, and who, it was hoped, would vie with Jenny Lind and Henrietta Sonntag. Great, however, was the failure and disappointment in store alike for artist and adorers. Pasta appeared only once-in Donizetti's Anna Bolena-and it would be ungracious here to enlarge on the fiasco.

During the spring I had the pleasure of 
welcoming to London three old friends and compatriots of mine-Jules Schulhoff, Charles Wehle (my pupil), and Alexander Dreyschock. The last-named (although he had visited London in advance of me) now made his first appearance at a morning concert at Covent Garden Opera House, playing, amongst other things, a piece for the left hand alone.

The next day we four pianists from Prague were assembled at Dreyschock's rooms in Manchester Street, when a gentleman sent up his card, with a message that he would not detain $\mathrm{Mr}$. Dreyschock two minutes. The visitor bore a good name, and was a Captain in the army. Entering the room, he addressed our host very stiffly as follows :

'Mr. Dreyschock, I came to make an apology, and hope for your forgiveness.'

At such a beginning we were all astonished, Dreyschock especially; for in what the offence could have consisted he was wholly unable to divine. However, the gallant Captain continued :

'I was at Covent Garden yesterday, at the back of a box, and had no programme. I was unaware, consequently, of the limitations under which that piece you played was performed. To 
tell you the truth, I did not greatly admire this particular item of your programme; but on reading in the Times this morning that you played it with the left hand only, I was filled with astonishment, mingled with regret that I had not sufficiently appreciated your skill. I now apologize for having withheld the admiration which your performance deserved.'

The reader will agree with me that it would be impossible to carry conscientiousness to a further point of perfection. Dreyschock was greatly amused, and for a long time could talk of nothing but the 'strange, courteous gentleman.'

In the year of the Great Exhibition (1851) people were too much taken up with the show in Hyde Park to pay particular heed to the musical events of that season, which, however, included the production of Thalberg's opera Florinda. The composer's father-in-law, the great Lablache, exerted himself to the utmost; everyone worked loyally, and Sims Reeves made an undoubted hit in a tenor air with chorus; but the libretto was so irredeemably dull that the work obtained a mere sıccès d'estime, and was only repeated a very few times.

Later in the summer a number of promenade concerts ('National' concerts, they were called) 
were given at the Opera House, my then pupil, Arabella Goddard, playing with great success.

I ought here to chronicle the settlement in England of Ernst Pauer, which dates from i $8_{5} 1$. He was a pupil of W. A. Mozart (son of the great composer), and is one of the very best pianists I have ever known, and quite an authority on musical subjects. He was too efficient not to succeed at once in gaining recognition in this country, where his name was already known as the recipient of honours at the hands of Emperors and Kings.

In I 852 Madame Pleyel performed frequently in London, to the delight of all lovers of the pianoforte, as did also a charming young pianist from my native place-Wilhelmina Claus, who won many laurels. Among other ladies of whom the musical world heard much were Mrs. Anderson and Madame Puzzi. The former was for many years the instructress of Queen Victoria and her children. Highly esteemed, and in the early years of the century a celebrated pianist, she still played in public. She died in 1878 , at the advanced age of eighty-eight. Mr. Anderson was the Master of the Queen's Music, in which office he was succeeded by his nephew, Mr. (afterwards Sir) William Cusins. 
Madame Puzzi had an enormous number of aristocratic pupils, and her annual concert was one of the best of the season. Her husband, a celebrated horn-player, had a large share in the management of Her Majesty's Theatre.

In the autumn I was engaged as solo pianist at the Birmingham Festival, where I played Mendelssohn's Concerto in $G$ minor. Christmas I spent in Vienna, remaining there until the middle of January. Between the and and I 4 th of that month I gave three very successful concerts in the Austrian capital. On the return journey to England I passed through Prague, and saw for the last time my dear mother, who died a few weeks later. That season I heard neither opera nor concerts.

In I 854 I married, and my wife and I passed a portion of our honeymoon with Liszt in Weimar. 


\section{CHAPTER XX.}

MORE OPERATIC EVENTS-I856-1858.

Covent Garden Theatre burnt-Sympathy with Mr. GyeThe Queen's condolence-Artists staunch-Opera at the Lyceum-Bosio-A brief career-Mr. Lumley at Her Majesty's-Piccolomini's début-A spoiled darling-Production of Traviata-The good offices of oppositionTimes letters and pulpit references-'The 'wicked opera' becomes the rage-Giuglini-A great tenor-Advent of Titiens-Parts in which she had no rival--Her success in oratorio-Her heroic self-sacrifice-Sings at my house in Brighton-Memorable obsequies-IVell-merited tribute.

THE utter destruction of Covent Garden Theatre by fire in 1856 was a severe blow to Mr. F. Gye, whose misfortune, however, evoked widespread sympathy, notably from Her Majesty the Queen, with whom the impresario was a great favourite. It is in such a calamity that friends are proved, and Mr. Gye had the happiness of finding all his artists staunch to him. $\mathrm{He}$ at once engaged the Lyceum for operatic performances, strengthening an already powerful company by the engagement 
of Bosio, who at once entered into popular favour. This ornament of the stage (she was one of the finest artists within my recollection) had a brilliant but too brief career, closed by her death, a few years later, in Russia.

At Her Majesty's Opera, Mr. Lumley, the manager, made a very fortunate hit with Mademoiselle Piccolomini, whose début took place on the occasion of the production of Verdi's Traviata -two events on a single evening. During the few years she remained on the stage, this fascinating little lady was the spoiled darling of the public. Sprung from one of the oldest families of the Italian nobility, she counted in her ancestral roll cardinals, warriors, and statesmen. Although I myself was greatly captivated by her, I never could understand the extraordinary furore she created. By no means a great vocalist, not particularly distinguished as an actress, small and agreeable-looking, but far from being a beauty, yet she created as great a sensation as though she united in her person the musical genius of a Jenny Lind and the dramatic power of a Rachel with the features of a goddess. How am I to account for her influence over man and woman, old and young? A little gesture, a certain coquettish toss of her pretty head, and 
everyone was in a state of rapturous delight. She played many characters; for instance, Traviata, Amina in Sonnambulu, Zerlina in Don Giovanni, Arline in Balfe's Bohemian Girl, La Figlia del Regimento, and many others-parts belonging to the repertoire of Jenny Lind and Henrietta Sonntag; and in every one she was as successful as if she had equalled these great and far superior predecessors. In private life she was so amiable, unaffected, and sympathetic, so far from occasioning trouble to others or giving herself airs, so perfectly ready to oblige, that her friends could but rejoice at the sway she exercised over the public.

As for Verdi's beautiful opera, it pleased at first without creating any extraordinary sensation; but, as so often happens, the opposition of an enemy helped to fan it into celebrity. Two days after its first performance, a long letter appeared in the Times, expressing in the most indignant terms the astonishment of the writer that a work of such immoral tendencies should ever have received the stage license. The letter was followed up by references from several pulpits on the succeeding Sunday. Then appeared another letter in the /imes, this time from Mr. Benjamin Lumley, as impresario of Her Majesty's 

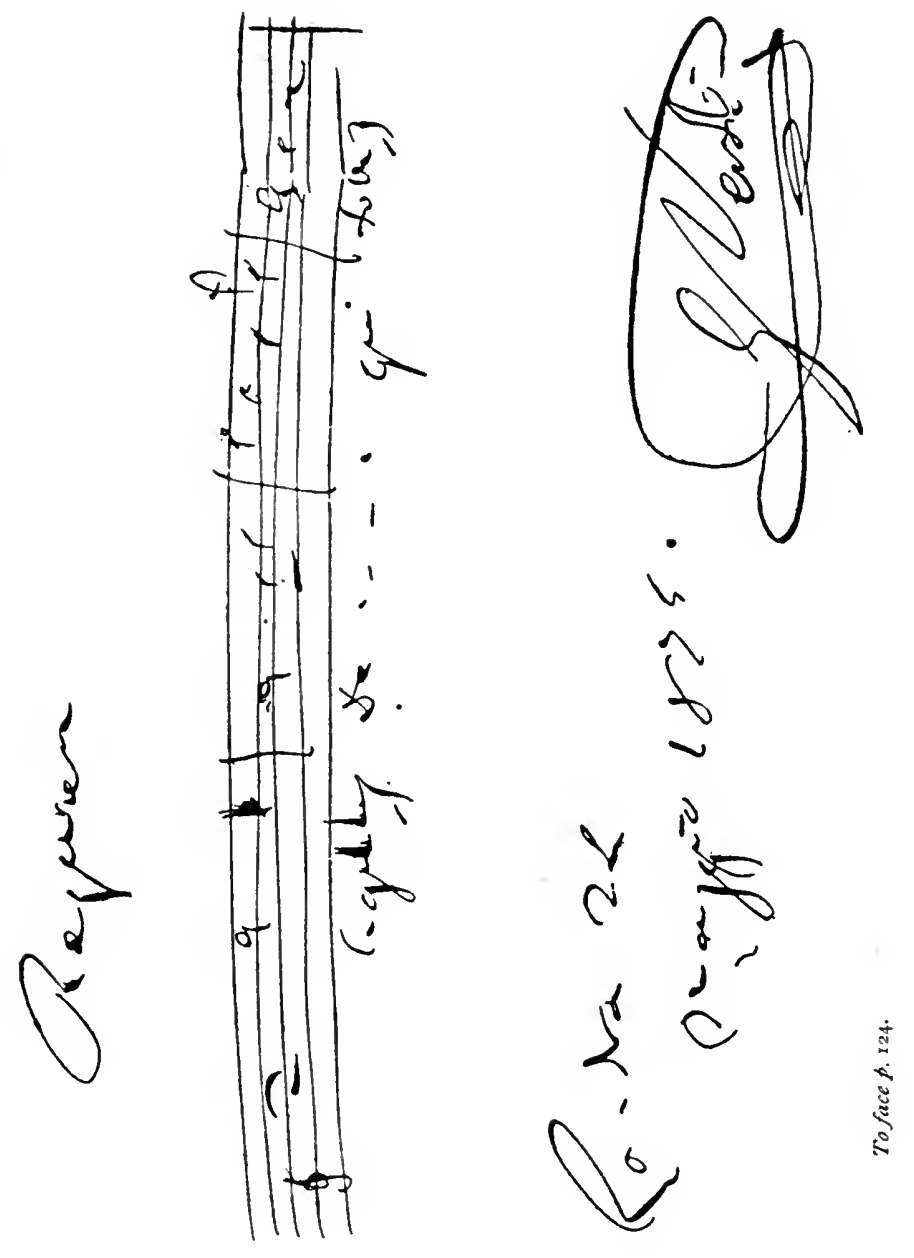

Opera, defending the tendency of the libretto, pointing out that, far from doing harm, it was rather calculated to impress on the spectators the invariable reward of virtue and the inevitable punishment of wrong-doing. The effect of all this controversy was that everyone was crazy to see this 'wicked opera,' which, after all, was merely the story of Dumas' La Dame aux Camellias, now witnessed by ladies, old and young, when played by Sarah Bernhardt and Eleanora Duse. Autres temps, autres maurs! In the course of the following season, Bosio gave a most refined and artistic rendering of the part of the ill-fated heroine; but we had to wait for the advent of Adelina Patti for a reading phenomenally attractive, both from a musical and dramatic standpoint.

The succeeding year (185i) witnessed the coming of a new tenor, who, with the exception of Tamberlik, proved the only formidable rival of Mario. This was Giuglini, who appeared in La Traviata. The beauty of his pure tenor voice and the great charm of his singing won him high esteem among lovers of operatic music. When, after some years of hard work, he left the stage, his departure was not attributable to a failing voice. It was due, unfortunately, to a mind 
unhinged. He was one of the three foreign tenors who have, so to speak, reigned over the public since I have been in England, the other two being Mario and, at the present day, Jean de Reszke.* Giuglini appeared also as Ottavio in Don Giovanni, and to him belongs the merit of restoring the beautiful aria Della sua Pace, until then for many years omitted, but in these days always included in Mozart's immortal chef d'auvre. As an actor, Giuglini could not compare with Mario.

In 1858 one of the greatest artists and one of the noblest women who ever trod the stage appeared in Les Huyuenots. Such of my readers as are old enough to have been frequenters of the opera nearly forty years ago will at once know that I allude to Theresa Titiens. I might worthily devote half a volume of these recollec-

* Tamberlik and, in the eighties, Gayarré ought in fairness to be mentioned as of world-wide celebrity. The former continued to sing when quite an old man with intense energy and earnestness. Naudin and Wachtel were among other prominent tenors. The former was selected by Meyerbeer to create the part of Vasco di Gama in L'Africaine. He was also the best Fra Diavolo I ever heard. Wachtel enjoyed during twenty years immense popularity in Germany and America. In England he was less successful. He was originally a cabdriver in Hamburg, but I don't know if that accounted for the fact that the Postilion of Longjumeau was his best part. $\mathrm{He}$ died in Frankfort in 1893. 
tions to her memory, not only because I consider her one of the truest artists of the century, but because she was one of the finest characters I have been privileged to know. Her voice was a rich, clear, and very powerful soprano-well becoming a dramatic singer who was especially great in such parts as Valentine in Les Huguenots, Donna Anna in Don Giovanni, Lucrezia Borgia, Ortruda in Lohengrin, Norma, Medea in Cherubini's now forgotten opera, and Leonora in $I l$ Trovatore. In all of these characters she may be said to have been absolutely without a rival. As the other Leonora, in Beethoven's Fidelio, she was quite a revelation to those who had never heard Schröder-Devrient in the part. The evening of her appearance in Les Huguenots, in conjunction with Giuglini (a worthy Raoul), was one not to be lightly forgotten by any who heard the applause which followed the splendid duet in the fourth act. In the course of her long career, there was, I think, only one among the parts she essayed for which she could be pronounced unfitted. This was the part of Marguerite in Faust, which she was the first to play on the production of the work in 1863 , when it was quite impossible to reconcile her tall and massive figure with the girlishness of an ideal Gretchen. 
Titiens was equally great in oratorio, particularly in the Messiah, and it was an immense pleasure to hear her at concerts in the familiar arias Softly Sighs (Frcischiitz), Ocean, thou Mighty Monster (Oberon), and other like dramatic pieces. There was, in a word, about everything she undertook that earnestness which distinguishes the real and perfect artist.

In private life never had woman more sincere friends. To all of them she proved herself completely unselfish, charitable, and self-sacrificing. A martyr during the closing years of her life to an incurable and very painful malady, she spent whole evenings of performance almost in agony, only going on the stage to prevent disappointment to the public and injury to her manager. So far, indeed, did she carry this forgetfulness of self that on one occasion, though really very ill, she undertook the journey to the United States, because her absence would have involved an entrepreneur in great pecuniary loss.

An instance of her graceful kindness to those she counted friends may here be set down. It occurred during a visit of the Italian Opera Company to Brighton, when Titiens was the 'star.' My wife happened that week to give an afternoon 'at home,' to which, ignoring indisposition and 
a busy evening which awaited her (she was to sing in Trovatore), the great artist did not fail to come. After staying about half an hour, she said to my wife, 'Now you must allow me to sing something to your friends,' and to our great delight, and that of our guests, she went to the piano and sang Com'e Bello and another air.

Titiens died in 1878 , exactly twenty years after her first appearance in the country which she made her own. Her funeral at Kensal Green called forth a remarkable tribute to her memory, not only at the hands of all who were distinguished in the musical, artistic, and literary worlds, but of the general public as well-a tribute, as was regretfully recorded at the time, somewhat marred by the mob too often permitted by ' the authorities' thus to desecrate our final reverence to the honoured dead. 


\section{CHAPTER XXI.}

\section{LISZT.}

Early memories-Visit to Vienna in 1838 -An eventful charity concert-Liszt fever in the Austrian capital-A plethora of invitations-Tour in Germany-Liszt's manners-His generosity-As a benevolent concert-giver-Beethoven's statue at Bonn - Cologne Cathedral-The Munich Hospital-How it was benefited-Liszt and the inmates of the Blind Asylum-A young 'cellist-His ambitions handicapped-'Wanted, a good instrument'-A welcome cheque-A pianistic dilemma-Liszt's loyalty to ErardThe rival firm-Remarkable tact-Illustration thereofGrand-Duchess of Saxe-Weimar-Concert at the Royal Castle-The young pianist's nervousness-Liszt's generous self-effacement-Etiquette satisfied.

LiszT! What memories cluster round the name! What a vista of recollections it conjures upespecially in the mind of one who, like myself, entertained the most profound admiration and sincere regard for the pianist and composer! It was in 1838 , a year that I can never speak of without calling forth associations of the most 
pleasurable kind, that I first heard the artist of whom everyone was then talking in hyperbole. Well do I remember the occasion! He came to Vienna for the purpose of giving a concert in aid of the unfortunate people who were suffering from the disastrous inundations in Buda-Pesth. Would that I could adequately describe the effect produced by that phenomenal artist! Suffice it that Vienna-artistic, music-loving and enthusiastic Vienna-was in a state of excitement such as I have rarely or never seen. Such playing had never been heard before. It was almost more than human. This was the universal expression of opinion, and everyone appeared electrified. That first and memorable concert was followed by many others, at which the same rapturous enthusiasm and indescribable excitement prevailed, and the lion of the hour found it, of course, impossible to resist the invitations that poured upon him to return in the following year. This he did, subsequently proceeding on his regular tour, which he commenced at Prague, where he gave no less than six concerts in the course of one week.

I think it was there that I was first introduced to him. I met him afterwards in Munich, Stuttgart, Vienna, and many other places. His personality was an extraordinary one. On all 
subjects an excellent conversationalist, he was extremely witty, possessing a keen sense of humour; his manners were, as all who knew him can testify, most fascinating; while his literary ability was indeed remarkable. And when I come to speak of his generosity, words altogether fail me to indicate that striking phase of his genial and kindly nature. Not only did Liszt give concerts and recitals promiscuously in the cause of suffering and distress, benefiting institutions in whatever town he found himself, but out of his pocket he assisted all who appealed to him to the fullest extent of the means at his disposal. It was Liszt who raised thousands for the erection of the Beethoven statue at Bonn and the completion of the Cathedral in Cologne.

I will only instance a couple of his acts of charity as they recur to me. Once, in passing through Munich, he gave a concert in support of the impoverished funds of one of the hospitals in that city. On its being pointed out to him that the inmates of the Blind Asylum were, in common with the great majority of the sightless, passionately fond of music, and had expressed a keen desire to hear him play, he forwarded more than a hundred reserved places to the institution, himself paying for the tickets, in order that the 
hospital in whose behalf he had organized the performance should not suffer.

Here is another instance.

Early in the forties a young violoncello-player, now a great celebrity, called upon Liszt in Paris, told him that he was handicapped from the want of a good instrument, and that an excellent one had been advertised for sale, but that he had not the means to purchase it, the price asked being 5,000 francs $(£ 200)$. He then said that he intended giving a concert, and would be very grateful if the virtuoso would consent to play for him. With his customary good-nature, Liszt at once complied with the request, which, so far as the result was concerned, was, of course, tantamount to presenting the young artist with a handsome cheque.

The story, however, does not end here. When the programmes were printed, Liszt, to his great consternation, found that the affair was to take place at the Salle Pleyel. Now, Liszt was an intimate and loyal friend of Monsieur Erard, the then rival of Pleyel as a pianoforte manufacturer, and, when in Paris, never played on any but Erard's pianos ;* and so it will readily be under-

* Another great pianist who also played only on Erard's instruments was Sigismund Thalberg. 
stood that the circumstance I have explained rendered it impossible for him, with the best will in the world, to fulfil the promise he gave to his young friend. Consequently, to the disappointment alike of the latter and of the 'lion' himself, his name had to be withdrawn from the bills. But it would not have been Franz Liszt, true friend and loyal artist that he was, had he allowed the matter to drop there. He discovered where the instrument was on which the 'cellist had set his heart, and, thanks to his munificence, the young man found himself its possessor on the very day of the concert at which Liszt was to have played. I record these particular incidents in a long and notable career because I consider them thoroughly characteristic of the warm heart and unselfish nature of the man of whom I am writing.

I should now like to say something concerning Liszt's unrivalled tact, and to illustrate it with the following story, which, I have reason to believe, is not generally known. A young, promising, and amiable pianist, whom I at that time numbered amongst my closest friends, obtained from the Queen of Prussia an introduction to the GrandDuchess of Saxe-Weimar. This was, I believe, in 1850 . The Grand-Duchess invited him to play at a Court concert. Here was an honour 
and an opportunity for further advancement, of which, needless to state, he gladly availed himself. There was a large and distinguished company present at the function, including, among other musical and artistic lights, Franz Liszt, who, I may mention, was always invited to the Court festivities. In the circumstances, it was but natural that the young man should manifest feelings of acute nervousness. Nevertheless, he acquitted himself admirably, playing a number of pieces very charmingly, and evoking praise from the distinguished audience.

When he had risen from the piano, the GrandDuchess turned to Liszt, and asked him to take the place left vacant by the young performer. This request was, of course, equal to a Royal command, and, as such; could not possibly be refused, save on exceptional grounds. But it may be conceived that it was a request which carried with it no little uneasiness to the heart of the young man who had just quitted the keyboard, and who, as most young and struggling artists would have done in like circumstances, naturally felt that, once the great master had enthralled the audience, the agreeable impression created by his own performance would be completely eclipsed. This was not jealousy; it was but the modest 
recognition of overwhelming and unapproachable superiority.

Realizing the obvious disadvantage under which his young friend would be placed were he to perform anything calling for a vivid display of his brilliant gifts, Liszt simply contented himself and his hearers by interpreting the first of Mendelssohn's Lieder, which, as every music lover knows, is, while a beautiful effusion of classic genius, not an excerpt of a 'showy' kind calculated to thrill an average audience.

Thus generously did the illustrious pianist, whilst complying with the Court demand, at the same time avert comparisons which, to the detriment of his young friend, would inevitably have been provoked had he 'laid himself out,' as they say in America, to enrapture his august hearers. 


\section{CHAPTER XXII.}

\section{LISZT}

(CONTINUED).

A recollection of Alexander Dreyschock-His Vienna concerts in 1846 -Octave-playing extraordinary-Chopin's Study -Another of the master's works - Liszt its interpreter-A sensational performance-Dreyschock eclipsed-The Concordia-A brilliant banquet-The Professor's request complied with-Eventful result-Phenomenal improvisation -A trio of improvisators : Mendelssohn at a Philharmonic concert, Stephen Heller, Ferdinand Hiller- "The last of the Mohicans'-The Prince of Hohenzollern-HechingenVisited by Liszt-My wedding-tour-We stay at Weimar with Liszt-Agreeable associations - Liszt as a host-The Princess Witgenstein-The post-prandial cigar-A colossal weed-Dr. Hans von Bülow-Liszt and his pupils-Visit to London in I886--Soirée at the Grosvenor Gallery-Some social functions-Liszt lionized-His strength overtaxed.

I MUST here for a moment revert to my compatriot, Alexander Dreyschock. When, in 1846 , the Bohemian pianist gave concerts in Vienna, it was, in particular, his octave-playing which created a furore. It constituted a 'sensational' perform- 
ance of a very remarkable character, and, as such, excited the easily-stirred Viennese public to a high pitch of enthusiasm. Dreyschock played Chopin's Study in C minor (No. I2, Book I.), in octaves. Pianists will understand the nature and difficulty of that astounding feat. Its performance by Dreyschock in masterly style was so successful that he was wont to include it in his programme at each concert, and it was in great measure owing to this particular tour de force that he succeeded on every occasion in filling the hall to repletion.

I mention this fact, which apparently has no connection with Liszt, because when the latter, in the following year, returned to the Austrian capital after a protracted absence, he announced for his first concert the performance, amongst other things, of Chopin's Study in F minor (No. 2, Book II.). He played it as only that master could interpret the Polish composer. The effect was electrical; the success instantaneous. After repeatedly bowing his acknowledgments, he was compelled, by irresistible plaudits, to resume his seat, when he again played the first bar of the study, doing so, with marked deliberation, in octaves. Repeating the same passage again and again, each time accelerating the tempo, he 
at last attained the speed at which he had played it in single notes, and he then proceeded to render in octaves the entire study, with all the crescendos, decrescendos, etc., as though he were playing the piece as it was originally written. The consummate skill with which he accomplished this remarkable feat amazed even an audience accustomed to his flights of bravura playing, and completely put into the shade the previous achievement in the same direction of Dreyschock.

I remember, when in Vienna, a banquet being given in his honour by a society named, if my memory serves me, the Concordia. This event, needless to say, brought together a most notable and brilliant gathering, representative not only of the nobility and the highest society, but of personages distinguished in art, literature and science. After the repast came the customary speeches, interspersed with music. I think it was Professor Fischoff, the Principal of the Conservatoire, who proposed the health of the popular guest, and the latter, I well remember, charmed all present with the speech, graceful, full of humour, and excellently delivered, in which he returned thanks for the hospitality accorded him.

Afterwards an artist, whose name I cannot 
recall, sang Schubert's Erlking, and was followed by the great German basso, Staudigl. The latter at this time had just returned from London, where for many seasons his name had been one to conjure with, and where he first heard what afterwards became a favourite song of his, Handel's $O$ Ruddier than the Cherry, which he sang on this occasion with all his accustomed charm.

But the great treat of that memorable evening was to follow. Professor Fischoff, who was sitting next to Liszt, taking advantage of the master's good-nature, asked him whether he would give the company an opportunity of hearing him. He at once acceded to the suggestion, and while at the piano held his audience completely entranced. The reception he met with on that occasion I shall never forget. It was enough to unnerve even an artist accustomed as was Liszt to overwhelming demonstrations. But while his fingers glided over the keyboard, the absorbed attention of his hearers-shown in silence that was almost impressive - was of the kind which has made the falling of a pin pass into a proverb. He played the first few bars of the introduction to the Erlking, and led up to the melody of $O$ Ruddier than the Cherry, which he rendered in the bass. I will indicate it thus : 


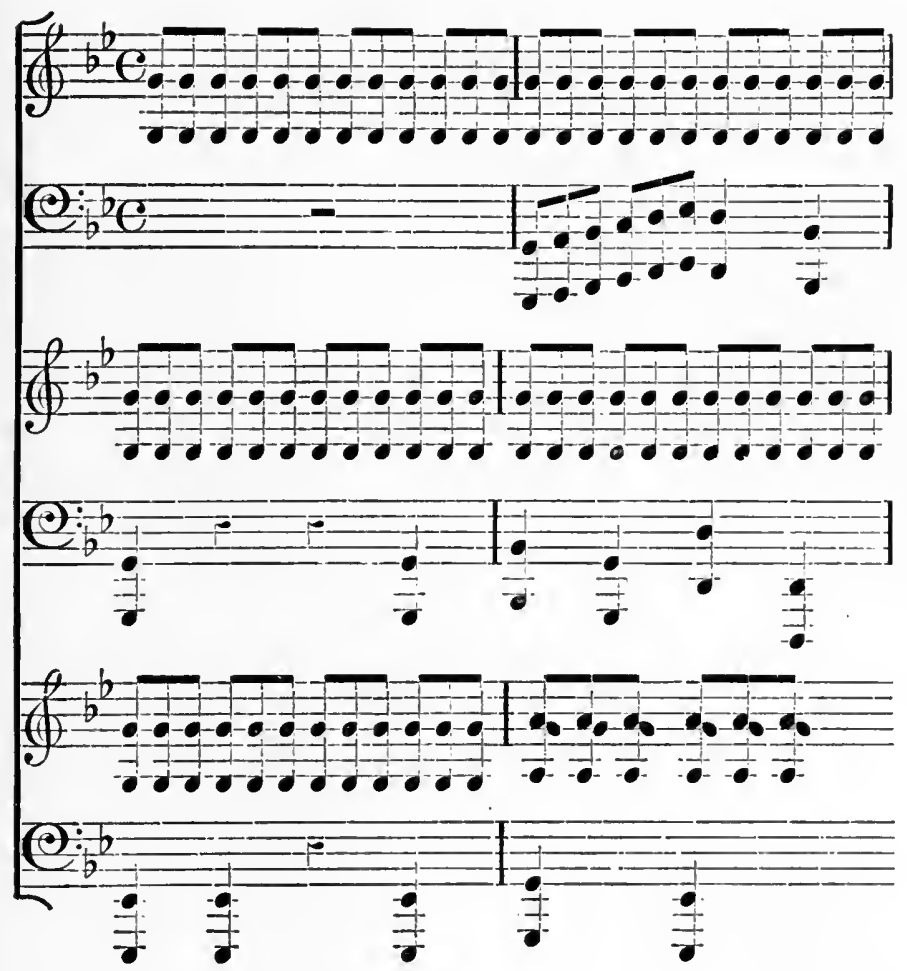

On these two songs he improvised so ingeniously, so brilliantly, producing such totally unexpected, weird, and extraordinary effects, that I should be doing the executant but scant justice were I to attempt to describe his masterly performance. The enthusiasm that followed it may easily be imagined.

In illustration of Liszt's phenomenal powers of improvisation, I may recall that on the occasion 
of his last stay in London he was visiting Mr. and Mrs. Beatty-Kingston, and while there noticed a manuscript song on the piano. $\mathrm{He}$ inquired whose composition it was, and was informed that it was by Miss Kingston, the daughter of his host and hostess. Liszt took the piece up, sat down to the piano, and at once commenced to improvise on the theme of the song. He did so in such a masterly and brilliant fashion, elaborating it so skilfully, that even the distinguished litterateur -himself an experienced and accomplished musician-in whose house the performance took place was astonished. There was nothing to suggest that the maestro was improvising on a piece he had never seen before. The idea conveyed was that of the carefully rehearsed rendering of a composition replete with technical difficulties and elaborate effects of harmony.

Incidentally I may here mention that in afteryears I heard three great masters improvise on the piano. At a Philharmonic concert at the Hanover Square Rooms, in I 847 -the year of his death-it was my privilege to hear Mendelssohn improvise cadenzas to Beethoven's Concerto in $G$ - a wonderful performance. The improvising of Stephen Heller was highly original, and that of Ferdinand Hiller quite masterly. I think I 
am correct in saying that Moscheles was one of the last pianists who excelled in that now almost forgotten art.

In 1850 I was on a visit to the reigning Prince of Hohenzollern-Hechingen, who conferred upon me the title of his Kammervirtuoso (Court pianist).* Among his guests was Liszt, who asked me to visit him at Weimar. I did so some years later (in I 854), when on my wedding-tour. To this day I look back upon the agreeable associations of that stay with unmixed pleasure. When I state that Liszt was as fascinating a host as he was an artist, my readers will be able to form some idea of the pleasure our sojourn in that artistic city afforded us. The Princess Witgenstein was doing the honours of the house, and very charmingly did she perform that duty. $\dagger$

* The Prince was a great lover of music. He composed a few songs, and kept his own orchestra, in the performances of which he used to take great delight. Every Sunday he arranged a concert, to which he was wont to invite all the principal inhabitants of the town. His wife was the daughter of the Duke of Leichtenberg, and sister of the Queen of Sweden. Of course, at the time of which I am writing, Hohenzollern was an independent principality; now it is incorporated with Prussia.

$\dagger$ One of the daughters of the Princess Witgenstein married Ollivier, the French Minister under Napoleon III. until the Franco-German War. 
Let me recall one rather amusing incident.

The Princess, like most Russian ladies, was an inveterate smoker, and after déjeuner, to my wife's intense amazement, offered her an exceedingly large cigar. In order not to offend our hostess, I persuaded my wife to 'make believe' that she was inhaling the fragrant but colossal weed; but her efforts in this direction were a complete and abject failure, and caused the Princess and her friends no little merriment.

It was at Liszt's house that I first met one of his favourite and most gifted pupils, Dr. Hans von Bülow, who died but a few months before I commenced these memoirs. When I was introduced to him, Von Builow was a young man of about twenty-four.

Mention of him as a pupil of Liszt reminds me of one of the latter's invariable rules. He had a great number of pupils, but from none of them did he ever accept any remuneration for teaching. This fact, not, I believe, generally known, was singularly characteristic of the man and his generous nature.

I will here close my present reference to Liszt with an allusion to his visit to London in the spring of 1886 . I then enjoyed several opportunities of seeing and hearing him, notably at 
a soirée given in his honour at the Grosvenor Gallery by his very talented and devoted pupil, Walter Bache; and at a reception organized by his compatriot, Dr. Duka, at his residence in Nevern Square. To those who had heard him at his zenith, and received an impression never to be effaced, it was, of course, most interesting to listen to him again in his sere and yellow leaf. But, for my part, I cannot look back upon that last visit of the lamented genius, for whom I entertained so profound an admiration, without a feeling of regret that he should have been led to display once again his rare gifts. For, in great measure, the old feu sacré, which had taken so many countless thousands out of themselves into a new world of music, had left him; and those who then, for the first time, heard the Abbé, can have formed no adequate idea of his unexampled powers in the years that were past. Alas! Franz Liszt was so much fêted, and underwent so much fatigue and exciting work during that last stay in hospitable and 'lion '-worshipping London, that he overtaxed his waning strength, and thereby, I doubt not, accelerated his death. which occurred two months later. 


\section{$[146]$}

\section{CHAPTER XXIII.}

\section{THE POPULAK CONCERTS.}

Production of $I l$ Trovatore in London - The cast - The Bohemian Girl à l'Italienne-Carvalho-Dinorah partly inspired by her-Her London début in L'Étoile du NordMeyerbeer-I meet him-His unassuming manner-The inauguration of the 'Pops'-Arthur Chappell-A pioneer of classical music in England-Pillars of the 'Pops'Albert Smith-A medical student-A wielder of the pen -Writes for John Parry-Becomes his rival-The Over. land Route-Inspiration on Mont Blanc-The Egyptian Hall as a national institution.

THE season of 1858 saw the production in London of that most popular of all favourite operas, Verdi's Il Trovatore. The cast included Titiens as Leonora, Giuglini as Manrico, and Alboni as the gipsy Azucena. Another attraction was Balfe's Bohemian Girl in Italian, with Piccolomini as Arline (and what a bewitching Arline!), Alboni as the Gipsy Queen, and, in the tenor part, Giuglini, who so enraptured the public with the Italian 


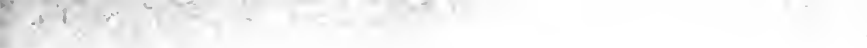




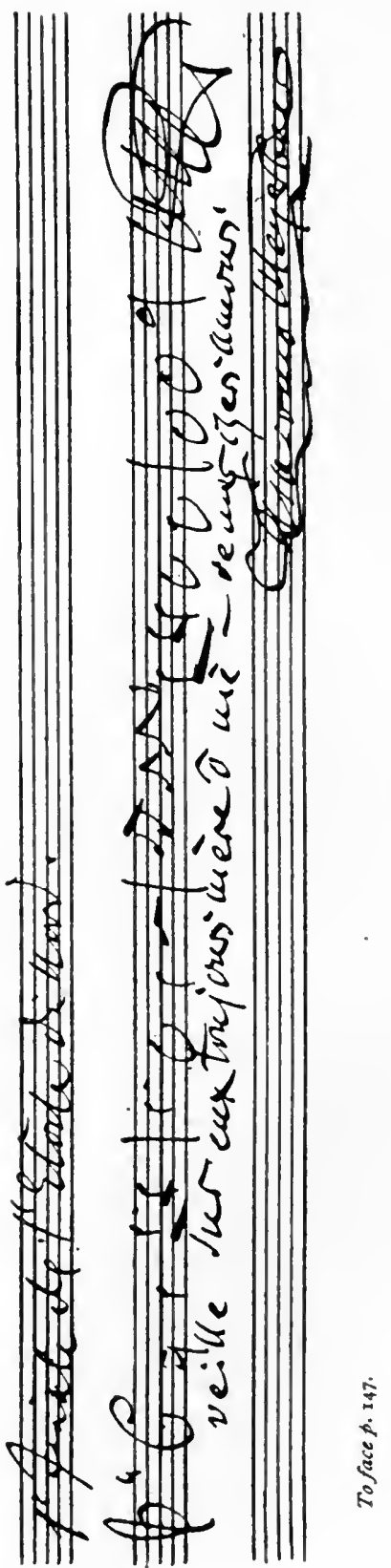


version of When other Lips that he was obliged to sing it frequently at concerts.

In the following year Madame Miolan Carvalho,* wife of the present impresario of the Paris Opéra Comique, made her début in London, winning here a popularity which went far to equal in degree that which she already enjoyed in Paris. Many parts were written expressly for this truly excellent artist. She was thus thrice honoured by Gounod, whose Marguerite, Mireille, and Juliette were all framed for her, while Meyerbeer wrote Dinorah with the notes of her voice ringing in his ear.

Her first appearance in London was made in L'Étoile du Nord of this illustrious composer, who came over to superintend its production. As originally written, the opera included a good deal of spoken dialogue, for which, in the Italian version, Meyerbeer substituted very ingenious recitatives. Of these the most important were for Lablache, who impersonated the Cossack-a small part, truly, but raised by his genius into one of great importance.

On the occasion of Meyerbeer's visit, I was introduced to him. I had been since my youth

* Her death occurred quite recently. 
one of his most fanatical admirers, in this respect differing from some present-day critics, who hold that he often prostituted his talent to win the approbation of the gallery. He was very kind and genial with me, but when speaking of himself, his modesty, to my thinking, was a trifle too profound. He paid me many compliments on my arrangement of the principal airs in his new opera, which he had heard me play the preceding evening at a concert, when, fortunately for my nerves, I was unaware of his presence.

But chief among the musical events of 1858 , I count the inauguration, by Arthur Chappell, of the Popular Concerts. The beginning was not encouraging, but the enthusiastic, art-loving founder of this unique series undauntedly persevered, receiving at last the reward he so richly deserved. It was, indeed, no small undertaking to offer the choicest examples of chamber music to a multitude accustomed to nothing more serious than popular ballads, arias from fashionable operas, and showy instrumental pieces. True, there had been quartette concerts for many years before the establishment of the 'Monday Pops.' There were the Blagrove quartettes, and Mr. Ella's Musical Union, at which chamber music was performed by such instrumentalists as Rubinstein, 
Charles Hallé, Vieuxtemps, Papini,* Piatti, and others; but they appealed to a restricted audience.

Certain aristocratic amateurs aided the director with liberal subscriptions; but the price of admission was high, and the number of the season's concerts limited. But Arthur Chappell, throwing open the then new St. James's Hall at the price for cheap parts of the humble shilling, put in the way of the public at large frequent opportunities of hearing the best music performed by foremost artists. He had, in this undertaking, the advice of the late J. W. Davison, musical critic of the Times. By such wise counsel he eventually profited to so great an extent that, developing his scheme as time went on, he may fairly claim to share with Charles Hallé and August Manns the honour of pioneering the cause of classical music in this country.

Let anyone desirous of knowing what Arthur Chappell has really accomplished consult the file of programmes of the 'Monday Pops' from their foundation down to the present day, and he will be astonished to see how many hundreds of classical works have been interpreted, under his

* An excellent violinist, who, after appearing at Ella's, settled in England and enjoyed much popularity. 
auspices, by the greatest performers who have ever appeared in this country.

At the beginning. A rabella Goddard, Charles Hallé and Piatti were the pillars of the establishment, much in the same way that the last-named, together with Lady Hallé and Dr. Joachim are at this day; but I will mention a few others among the very many who contributed to these Monday and Saturday entertainments. For, one evening a week soon proved insufficient to accommodate the supporters of the enterprise. The roll of performers, then, includes such illustrious names as Clara Schumann, Fanny Davies, Agnes Zimmerman, Ilona Eibenschiitz, Hans von Bïlow, Rubinstein, Paderewski, Leonard Borwick, Sauer, Rosenthal, Reisenaur, Arbos, Johannes Wolff, Strauss, Ries, Popper, Whitehouse, the great German clarinettist Mühlfeld, and his never-tobe-forgotten colleague Lazarus. For many years the task of accompanying the vocalists was performed by Sir Julius Benedict, whose services helped not a little to consolidate the enterprise, which has developed with years into a national institution. That task is now worthily performed by Mr. Henry Bird.

My reminiscences of the fifties would be incomplete without some reference to Albert Smith, 
whose popularity as an entertainer has hardly been exceeded. As a medical student he showed considerable literary talent, and eventually gave up his intended profession to become a wielder of the pen. He was successful as a novelist, and not less so in light dramatic literature. He also, as many will remember, furnished a libretto for John Parry, when that clever artist resolved to devote an entire evening to a humorous sketch. Albert Smith, in view of John Parry's success, decided to devise a second entertainment, this time for his own use and the benefit of the public. The result was his production of The Overland Route. There was not a dull moment in it, so that his success quite rivalled that of Parry in the same line.

A year or two later he took a holiday, went to Chamounix, and made the ascent of Mont Blanc. Here, he thought, was a subject lending itself admirably to his peculiar treatment. The Egyptian Hall, accordingly, was transformed into a Swiss châlet, with scenery representing the neighbourhood of Chamounix, including, of course, the monarch of the mountains. The performance soon became a regular institution; one or two new characters, and perhaps a couple of songs, being introduced each year, but the backbone of 
the entertainment remained virtually unchanged. Everyone paid an annual visit to the Egyptian Hall, and I verily believe that but for the untimely intervention of an early death, Albert Smith would still have been delighting Londoners and their country cousins at what is now 'England's Home of Mystery.' 


\section{CHAPTER XXIV.}

ADELINA PATTI.

'A little girl is to sing Amina - A wonderful début-How the 'little girl' acquitted herself-Mr. Gye receives congratulations - The young diva's appearance in Brighton-Visit to Vienna - Meyerbeer's admiration - Dinorah - Flaw in a contract - Patti's rendering of Rossini's music--- Her attitude towards Wagner-Signor Nicolini-His likeness to Mario - Her master, Maurice Strakosch, and his double-Some curious mistakes-Stopped in Bond Street -A strange request - 'Not my sister-in-law'-A Paris incident-Tale of an umbrella.

ONE morning in I 86 I business took me to call on Mr. Frederic Gye, who, as he bade me adieu, said :

'Come to Covent Garden to-night and hear Sonnambula. A little girl is to sing Amina, and I shall not be surprised if she makes a big hit.'

I took his advice and went. The little girl turned out to be a pretty child-to all seeming, of about fourteen. On making her first entry she had no reception, for, amazed at the sight of a 
mere child stepping on to the stage to essay the part identified with Malibran, Jenny Lind, Persiani, and other great stars of the operatic firmament, the audience was too much taken aback to applaud.

Her singing of the first recitative arrested attention; but the aria which follows (Come per me sereno) was given with such beauty of voice and finish of execution that it became evident that we were listening to no ordinarily gifted mortal. As the opera progressed, so did the enthusiasm of her hearers increase, until at last a magnificent rendering of $A h$, non Giunge crowned the triumph of the 'little girl.' Here, it was manifest, was no case of merely exceptional talent; we were face to face with phenomenal genius. The next day's papers, heralding the extraordinary success of the new 'star,' voiced but one opinion. For the second performance tickets were sold at a premium, and on all hands Mr. Gye received felicitations on his lucky 'find.'

My readers will have guessed that the new-comer was none other than Adelina Patti. If, therefore, in 1895 , thirty-four years later, Adelina Patti appears at Covent Garden with a voice of matchless beauty, and people readily pay five and six guineas for their stalls, declaring her to be without 
a rival-if, I say, such things be-do I exaggerate when I assert that hers is a genius truly phenomenal ?

At the close of the London season of 1861 she came one evening to Brighton to sing at my concert, this being her first appearance on a concert-platform in England. She then went to Vienna, accompanied by her parents and her brother-in-law, Maurice Strakosch, who was at the same time her singing-master, and between whom (it may be incidentally mentioned) and myself there existed such a strong resemblance that we were not infrequently taken for one another.

In Vienna Patti at once created the sensation which she has never failed to make, whether in England, France, Austria, Germany, Russia, America, or, indeed, wherever she has sung. Meyerbeer, on hearing her for the first time (I believe it was at Vienna), became one of her most devoted admirers, and presented her with the score of his latest opera, Dinorah. Patti at once took a fancy to the title-rôle, which she made one of her most famous impersonations-I might say 'creations,' for to those who heard her in the past she was the only Dinorah. She sang it in London in 1862. 
During the young diva's stay in Vienna, it was found that a contract signed by herself alone had no binding power, since she was not of age. Mr. Gye had, therefore, to renew his agreement with her for three years on terms much more advantageous to her than those of the former contract. In this, as in all that concerned her interests, her brother-in-law proved himself a keen business man, in which respect his likeness to myself was not very pronounced. No one will expect me to criticize Patti's rendering of every part she essayed. I will, however, mention a few of her more especially remarkable performances. First and foremost I will place her Violetta in $L a$ Traviata, because her assumption of the part, both vocally and dramatically, is unapproachable. Her singing of Ah forse a lui, in the first act; the two duets with Alfreda and the elder Germont, as well as her interpretation of the death scene-of these no pen could convey an adequate idea.

What a contrast to her Violetta was (and, I am happy to say, is) her Rosina in that comic masterpiece Il Barbiere! Will such another Rosina ever charm us? How simple and natural, how coquettish and humorous, how vocally perfect! No wonder the raptures of the composer equalled 
those of Meyerbeer as he heard a realization of his ideas so mature! Of her Dinorah I have already spoken. Who will ever forget the shadow song, in which the grace of Patti the dancer equalled the bird-like qualities of Patti the singer ? How bewitching, again, was her impersonation of Zerlina in Don Giovanni! In the two songs, Batti, Batti and Vedrai Carino, as in the duet La ci darem, not a single note is added or altered by her, everything being left in its native simplicity and purity, ornamented only by the inherent charm of a consummate artist, who makes Zerlina one of the most important characters in the opera.

Regret has been oftentimes expressed that, in a repertoire so extensive, Patti has never seen fit to include the rôles of Wagner's heroines. For my part, I think her decision in the matter a most happy one. Ardently as I admire Wagner's wonderful creations, I must admit (although I know how much opposition my remark may arouse) that his music is fearfully trying to the voice, which is entirely sacrificed to the orchestra. Had Patti devoted herself to become an exponent of Wagner, that master's works would doubtless have received an added lustre. Her singing, within the last two years, of his Träumerei and the prayer from Tannhäuser has proved how admirable she might 
have been as Elsa or Isolde ; but had she undertaken these parts, it may at least be doubted whether her voice could have retained its richness and purity during all these years.

I spoke just now of Adelina Patti's brother-inlaw as her singing-master. But did she ever require one? I maintain that Adelina Patti would still have been all that she was thirty years ago, and is now, even if no one had trained her in voice-production-scales, shakes, and all the other departments of vocal tuition. In her, all accomplishments of that kind were inborn. In my humble opinion, Rachel would have acted as she did without any histrionic tuition; Liszt would have played as he played without any pianoforteteacher; Mozart would have written Don Giovanni, Beethoven the nine symphonies, and Wagner Tristan and the Parsifal without any regular instruction in composition. For all that, I should be the last man to advise young students to neglect making a serious study of their profession, as very often they do, even if they feel quite certain that they are born geniuses equal to rank with the incomparable artists whose names I have just mentioned.

I will say nothing here of Patti's beautiful castle in South Wales, the scene, year in and year out, 
of princely hospitality, nor of her acts of benevolence in the Principality, which have made her idolized near and far. But before taking leave of her for the present, I will mention that, to my intense gratification, this most amiable of prima donne has sung year after year at my concerts in London and Brighton, and has made with me two tours through the principal cities of England and Scotland.

It may be not altogether inappropriate to conclude this chapter with a few words about the diva's gifted and popular husband, Signor Nicolini, whom I first met in I 87 I during an interview with Mr. Mapleson at Her Majesty's Theatre. As Nicolini entered the room, I was so struck by his resemblance to Mario that, unintroduced, I was on the point of shaking hands with him. Making his first appearance in London as Edgardo, in Lucia, he proved himself one of the finest tenors ever heard in this country. He was very handsome, his voice was a real tenor of exceeding beauty and most artistically managed, while his acting was both manly and graceful.

Nicolini had been originally trained at the Paris Conservatoire as a pianist, but making the discovery that he possessed a voice of fine calibre, he wisely devoted himself to its cultivation. $\mathrm{He}$ 
retired from public life far too soon, for even at this day his voice is in splendid preservation; but he prefers to lead the life of a country squire.

Early in this chapter I referred to the remarkable similarity in appearance between Maurice Strakosch and myself. So marked was this resemblance, that it led to some curious mistakes being made. For example, I once called upon the Marquis de Caux and his wife, who were then staying in Gloucester Terrace, Regent's Park, and, on entering the room, the diva's husband greeted me in French with the words:

'Ah, Maurice, you are the very man I wanted to see-in fact, I had just written to you.'

Of course, the moment I approached him he saw his mistake, and, in laughing over the episode, he remarked that it was a good thing his wife's brother-in-law and myself. were both highly respectable members of society, for otherwise the failings of the one might possibly put the other to serious inconvenience.

On another occasion, even my friend, the late Mr. J. M. Levy, mistook Herr Strakosch for myself. Strakosch was paying a call at his house in Lancaster Gate, and happened to be sitting at the piano when Mr. Levy came into the drawingroom. On seeing him, he exclaimed : 
- Well, Kuhe, and what news do you bring us ?'

Two other incidents arising from my likeness to Patti's brother-in-law recur to my mind. I was once walking down Bond Street, when a gentleman stopped me and said he had a slight favour to ask of me. I thought he might be going to suggest a small loan; but his next words reassured me. He was most anxious, he explained, to hear my sister-in-law sing at the opera, and would be greatly obliged if I would procure for him a seat at Covent Garden the following evening. Slightly disconcerted, I replied that no sister-in-law of mine was appearing at the opera, so that I could not possibly grant his request. He looked incredulous, and said :

'I always understood that Adelina Patti was your sister-in-law, Mr. Strakosch.'

I then informed him of my identity, upon which the stranger apologized profusely, but added:

'It's most extraordinary!'

I really believe he was only half convinced.

The other incident, which struck me at the time as extremely ludicrous, occurred in Paris when I was staying there with my wife and family. I was conversing with a friend in the foyer of the Opera House, when a stranger, approaching me with some diffidence, said : 
'I must apologize for interrupting you, and I have also another apology to offer you. The fact is-and I regret it sincerely-that on leaving the club rather hurriedly last night I took up your umbrella in mistake for mine. They are very similar-both handles mounted in solid silverbut this morning I noticed that the one I had taken bore the initials "M. S.," and in wondering where I could have picked it up, I recollected seeing you last night. I have taken your property back to the club.'

When I told him he was mistaken, and that I had not been to any club, and had lost no umbrella, he looked bewildered, and said :

'But surely you are Monsieur Maurice Strakosch?'

On assuring him to the contrary, he seemed quite staggered, and was only able to articulate 'Mille pardons!' and walked away.

Appended is a letter, bright and characteristic, which I received some years ago from Adelina Patti. 
de li gant di' Enmext et

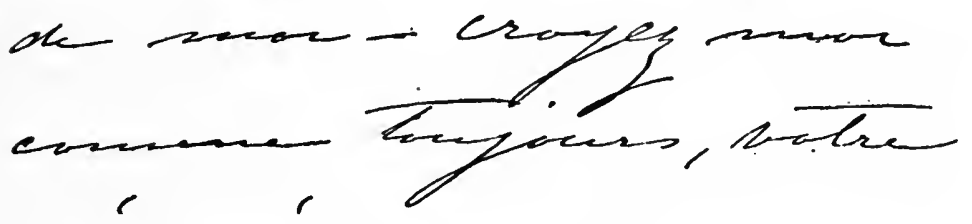

océnacér

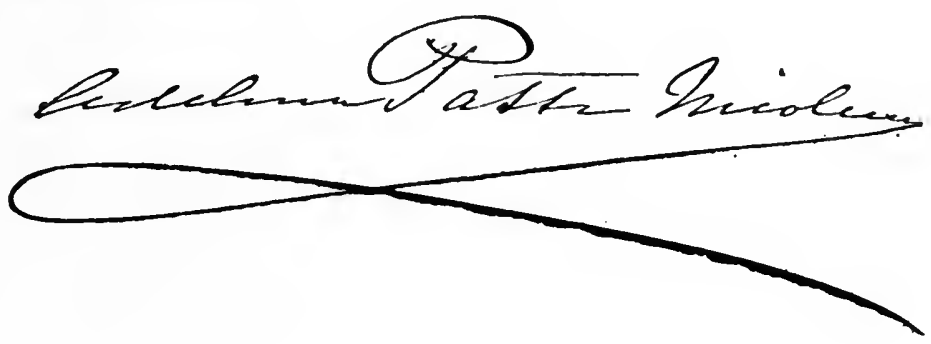

To face p. $16 z$. 



$$
[163]
$$

\section{CHAPTER XXV.}

\section{TREBELLI.}

First heard in Prague-A true interpreter of Rossini-Introduced in London by Mr. Mapleson-From 1862 to 1890 -A tour through England-A universal favourite-The singer's invariable good nature - A prompt understudyBettini-Mademoiselle Antoinette Trebelli-Her studies in Paris-Trial appearance at St. James's Hall-An audience of one-Trebelli as a raconteuse-A memorable dinner - Ineffaceable recollections - Songstress, reciter, linguist, mimic and traveller-A fascinating hostess-The daughter's début.

A the end of the first Patti season I paid a visit to Prague, an annual duty until my father's death in I 87x. I was informed immediately on my arrival that a new singer, whose name was unknown to me, was turning the heads of my compatriots at the Bohemian National Theatre, where, between the acts, she was singing Rossini's now almost forgotten aria, Non piu Mesta, and Nobil Signor, from the Huguenots. Going without loss of time to judge for myself, I was at once impressed in 
favour of the cantatrice, who was none other than the since famous Trebelli. As soon as she began to sing, it was clear to me that she possessed a rich, beautiful contralto voice. As she proceeded, I discovered that she had been trained in the best school; and by the time she had finished the old-fashioned air, I had formed the opinion that she was one of the very few vocalists left who knew how to interpret Rossini's music. Nobil Signor she sang with greater perfection than anyone I had ever heard. I was simply enchanted; and had I been an operatic impresario I should not have hesitated about offering her on the spot an engagement for a long term of years. I was destined to meet the wonderful songstress in London the very next season, little dreaming when I did so that our acquaintance would ripen into true friendship.

Mr. Mapleson, who had already brought out so many great artists, introduced her to the English public in I862. Her success, complete from the first, continued without intermission until twenty-eight years later, when a serious illness disabled her. During her long career she regularly appeared in London every season, and as regularly in the provinces during the winter. Not a year passed in which she failed to assist at 
my concerts in London or Brighton; while once also she made a tour with me through England.

Trebelli was a universal favourite, beloved by her managers and all her fellow-artists. Never have I known a singer so ready to oblige and willing to get a manager out of a difficulty. She would undertake the smallest parts, such, for instance, as one of the three genii in Il Flauto Magico; and I verily believe that had it been required of her she would have sung in the chorus.

I well remember a certain performance of Faust, when the part of Siebel, always one of Trebelli's best and favourite characters, was undertaken by Madame Demeric Lablache. There being, as it happened, no one ready to sing the small part of Marta, Trebelli undertook it without a moment's hesitation, going so far, even, as to offer her services. Her voice, I may mention, blended beautifully with Titiens'; and their performance of the duet Giomo d'Orrore, from Semiramide, was always a sure 'draw' for the concert-room.

A great traveller, Trebelli sang in Germany, France, Russia and Sweden (I am uncertain about Italy). She was an excellent linguist, and the best raconteuse I ever met, full of wit and animation. She married Bettini, a tenor who used with admirable taste a not very powerful voice.

In $188_{3}$ (to the best of my recollection) Trebelli 
spoke to me much about her daughter Antoinette, who was then finishing her education in Paris. This young lady, I learned from her lips, had a beautiful soprano voice, and, inheriting her mother's talent, had been placed by her under the singing-master to whom she herself and Christine Nilsson owed their training (W'artel). Trebelli expected her daughter in England at an early date, and was anxious that her début should take place uncler my auspices, and that she should appear at my annual concert. To such a request I could only give my readiest consent. Shortly after Mademoiselle Antoinette's arrival, it was arranged that I, as sole listener, should hear her sing at St. James's Hall, and form an estimate of her powers. I did so, and saw at once that there could be no doubt about her success.

On the Sunday before the concert I dined with Madame Trebelli at her house in Abbey Road, St. John's Wood. We were a very small partythe hostess and her daughter; her Italian doctor and his wife (their name I cannot recollect); Signor Bisaccia, who invariably played Trebelli's accompaniments; our mutual friend, N. Vert, and myself.' That evening is indelibly registered in my memory as one of the most pleasant in my life. After dinner and subsequent music, to which both mother and daughter contributed, 
Madame Trebelli gave a unique entertainment. She recited in various languages, gave a representation of marionettes, and parodied a rehearsal of the Garden scene from Faust, humorously depicting the stage-manager as an ancient dancing professor, who capered about the stage showing the performers how to act their parts.

Our greatest treat, however, was in listening to her description of her travels in Russia, Sweden, and Norway. Some of her concerts in those countries had been given in small towns, occasionally in mere villages, where she had to resign herself to the most primitive accommodation. Her powers of mimicry, her vivid narration, her sprightly humour, her chic and bewitching animation, all were brought into play with an effect which I cannot describe. When we left, at two in the morning, it seemed to us at least three hours earlier, so swiftly had the evening sped under the charm of our brilliant and fascinating hostess.

Painfully nervous was that great singer when the day of the concert I have mentioned arrived, and she had to appear on the platform in company with her daughter to sing the duet from Donizetti's Maria Padilla. Fortunately the success was unequivocal.

Trebelli's death is still fresh in our minds, and her loss is felt to this day. 


\section{CHAPTER XXVI.}

' FAUST.'

Difficulties attending its production in England-Faust and Carmen as stop-gaps-Messrs. Chappell's rights - The price of an immortal work-A lucky 'find' for publishers and impresarios-Production at Her Majesty's-A notable cast -Doubtful reception-Subsequent crescendo of success - Mapleson's exanıple followed-Carvalho as Marguerite -Rival casts - Pauline Lucca in Huguenots - A delightful Marguerite--In L'Africaine and Fra Diaiolo-German opinions-At the Court of Berlin-Prince Bismarck and Lucca - An incongruous photograph-Baron RahlenA devoted wife-Lucca's theatre in Austria-Musical and dramatic academy-Mario's Faust-Giuglini, Jean de Reszke and Nicolini-Patti as the heroine-The Garden scene at Brighton-Christine Nilsson-An ideal Gretchen.

Opera-goers of the present day, accustomed to a weekly, or even a bi-weekly, performance of Gounod's Faust, can hardly be expected to realize that its production in London thirty-two years ago was not decided upon without much hesitation. Yet such was the case, and the initial performances promised oniy a very doubtful 
reward for the apparent temerity of Mr. Mapleson in introducing it to the British public. In these days, whenever, through unforeseen circumstances, it is necessary to substitute for the opera advertised to be performed on a certain evening some other work, the choice of a manager generally lies between Faust and Carmen. In either case he feels that the disappointment of the audience will vanish as soon as the ear is greeted by the strains of Gounod or Bizet ; but bold indeed would have been accounted the prophet foretelling in $186_{3}$ a success so enduring as that which has fallen to the masterpiece of one of the most prolific among French composers.

The respective impresarios of the two Italian Operas had been urged for years to put Faust upon the boards; both, however, fearing failure, felt themselves unable to comply with any proposal of the kind. Some years previously a nephew of Messrs. Chappell had purchased for that firm the publishing rights of the opera for the ridiculous sum of $£_{40}$; but, so far, there had been no demand for the music, and it seemed as though the amount paid had been an absurdly high price for so very doubtful a privilege. At length, through the in-

* Curiously enough, for his next opera (Mireille), which was never a success, Gounod received from Messrs. Boosey $£ 800$. 
fluence of the firm, Mr. Mapleson was prevailed upon to produce the work, which was destined to prove, as all the world knows, a veritable goldmine for publishers and impresarios (and, let us hope, the composer), and for the public a source of never-failing delight.

The work was first heard at Her Majesty's Theatre with the following cast: Marguerite, Mademoiselle Titiens; Siebel, Madame Trebelli; Faust, Giuglini ; Valentine, Santley ; and Mephistofele, Gassier.

By no means very favourable was the reception of the opera. With the exception of the old men's and the soldiers' chorus and the tenor air, Salve Dimora, nothing in the work seemed to take the fancy of the audience, who nevertheless were found much less frigid at the second representation, while a veritable triumph awaited the third, from which occasion dates the firm establishment of Gounod's chef-d'aure as the most universally popular of all operas.

Constrained to follow Mr. Mapleson's example, the rival management at Covent Garden was fortunate in securing for the part of Marguerite Miolan Carvalho, its creator in Paris, while Nantier Didier essayed the rôle of Siebel, Tamberlik that of Faust, Graziani impersonating Valentine, and Faure completing the cast as 
Mephistofele. Giuglini and Santley at the other house surpassed their rivals at Covent Garden, but Miolan Carvalho, and particularly Faure, outvied the impersonators of their respective parts at Her Majesty's.

In the following year, I 864 , during which the success of Faust continued unabated, some important changes were made in the cast, Mario appearing as Faust, and Pauline Lucca as Marguerite. The latter, who had made a most promising début as Valentine in Les Huguenots, proved (if I except her rendering of the Jewel song, in which her vocalization was far from perfect) an excellent Marguerite, her acting, particularly in the Cathedral scene, being fine beyond words. She displayed, indeed, actual genius in everything she undertook, and was equally admirable in tragic and humorous impersonations.

In Meyerbeer's L'Africaine, I do not think she can be said to have admitted a rival, and her Zerlina in Fra Diavola, to my mind, has not yet been surpassed. As Cherubino in the Nozze di Figaro, she was equally bewitching, although, possibly, sticklers for tradition may object to the manner in which she sang $V o i$ che sapete. Her Mrs. Ford in Nicolai's Merry Wives of Windsor was not heard in England; but in Germany it was considered with Carmen one of her most 
famous creations. Her acting in it was the perfection of real humour.

Pauline Lucca was an especial favourite at the Court of Berlin, Prince Bismarck delighting in her clever and witty conversation. There used to be, I remember, in the shop-windows of the German capital a photograph representing the old Emperor William, Prince Bismarck, and Pauline Lucca.

In I 870 her husband, Baron Rahlen, was wounded during the campaign in France, whither she followed him to act as his nurse. She performed the same womanly office for a brother officer of her husband who shared his sick-room. Her devotion was powerless to save Baron Rahlen, whose friend, however, survived to marry the widow.

Madame Lucca has now a theatre in Austria, where she trains aspirants to the stage in singing and acting, an occupation which doubtless provides her with ceaseless opportunities for the exercise of that charming good-humour which in the old days made her a general favourite.

Mario, both in appearance and as an actor, was an ideal Faust, but vocally it was never one of his best parts. Salve Dimora he tried in several keys, but he never, to my mind, wholly succeeded 

Pour. Banete Wuke avec $\sqrt{2}$ mcitleur forwemis.

9 fuither/ly.

Ch.

Zniffoste Moufa.

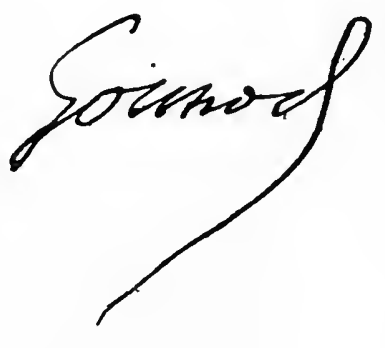

Toface p. 173. 
in any of them. Giuglini's singing of the air was splendid; but the very best Faust yet seen from the point of view of personal appearance, as well as vocally and dramatically, is undoubtedly Jean de Reszke, though Nicolini was certainly superb in the part. Towards the end of the season of I \$64, Adelina Patti* appeared as the heroine, when for the first time was heard a Marguerite such as Gounod might have dreamed of, perfection of roice, singing and acting being in this new Marguerite personified. What a feast it was to hear the Jewel song given at length with matchless excellence, and to see associated with the singer such a Faust as Mario looked, and later one who impersonated the character as Nicolini did!

A few years later, London opera-goers were sent into raptures by the appearance as Marguerite of Christine Nilsson-in looks an ideal Gretchen, such as any student of Goethe might have pictured, and in dramatic intensity equal to any artist who had previously been seen in the part.

Appended is a facsimile that will interest admirers of Gounod.

* Only last year ( 1894 ) I persuaded Patti to sing the entire Garden scene from Faust at one of my Brighton concerts as an operatic recital. The success was nothing less than sensational. 


\section{CHAPTER XXVII.}

ROSSINI.

A remarkable arrival at Kissengen - Rossini's vow against railways-Great men's fancies-Auber and Paris-A true boulez'ardier - Walks with Rossini-His sarcasms-Origin of the Stabat Mater-A juvenile attempt-The master in Paris-His secretary, Louis Engel-Saturday receptionsThe guests-Alboni, Taglioni, Lefort and Gustave DoréRossini's love of home-His 'eighteenth' birthday-Poniatowski-An opera produced by Court influence-Rossini's counsel-An elegy on Meyerbeer-Chaos-Opinion of Tannhäuser-A Christmas gift-The drummer's rest.

Aвout the middle of the sixties (I think it must have been 1865) I took my family to Kissengen. One day, to the surprise of the promenaders, a huge travelling carriage was seen approaching, heavily laden with luggage. This marvellous equipage contained a very stout old gentleman with a remarkably fine head, by whose side was an elderly lady, while the coachman's seat was shared by a valet de chambre. In those days, road-travelling being already considered an ec- 
centric mode of progression, much speculation was aroused as to the identity of the occupants. The old gentleman proved to be a celebrity of the first water, one of the greatest geniuses ever given to the world-none other, in fact, than Giacomo Rossini, the immortal composer of $\mathrm{Il}$ Barbiere cii Seviglia and Guillaume Tell.

Rossini, when railways were instituted, had registered a vow that he would never adopt a means of locomotion so little suggestive of Art, and so entirely at variance with Nature. Well, great men have their fancies. Auber, the no less illustrious contemporary of Rossini, would never for any consideration leave his beloved Paris. In I 870 , during the siege, every persuasion was tried to induce him to quit the unfortunate capital, but in vain. He was considerably over eighty years of age, and could neither suffer the privations incidental to a siege, nor the doleful aspect of a city usually so gay, but given over, under such sad circumstances, to misery and starvation, and he died during that eventful period.

But to return to Kissengen. I very soon made Rossini's acquaintance. Besides exchanging frequent calls, we took every day two or three walks together. He was very fond of talking, freely expressing his opinion of everybody and about 
everything. He seemed never to fear giving offence, nor did he care at all if his criticisms were repeated to the individuals about whom he had spoken his mind. He was full of sarcasm; but oddly enough, and perhaps fortunately, whatever he said was received as a good joke, and instead of feeling hurt, people wisely went and told their friends that Rossini had made butts of them for his sharp, keen wit. Occasionally he talked in a milder vein.

'You know,' he said to me one day, speaking of Auber, 'what pretty dance tunes he has always written!'

Talking another time of his celebrated Stavat Mater, he gave me an account of the origin of that work. He had, as a boy, a school chum who afterwards entered a monastery. Being passionately fond of music, the ecclesiastic asked his old school-fellow, with whom he kept up a constant correspondence, to compose a Stabat Mater for him.

'Now, you know,' said Rossini to me, in referring to the request, 'one cannot suddenly jump from the stage into a church. However, I promised, hurriedly wrote the work, and sent it on to him.'*

* I may here mention that there are many monasteries on the Continent whose inmates are allowed to employ a portion 
Rossini's correspondence with his friend slackened with time, and at length ceased altogether, and the maestro lost all recollection of having written a Stabat Mater. His monastic friend dying some years later, unknown to Rossini, the manuscript of the work was sold, amongst other things, to a French publisher. One day, to the composer's intense astonishment, he saw in Paris an advertisement announcing the 'First performance of Rossini's Stabat Mater.' Inquiries elicited the fact that the result of his juvenile attempt at sacred composition had cropped up in an unexpected quarter. He would gladly have stopped the performance; but this he was legally powerless to do. The Stabat Mater, as everyone knows, proved to be one of Rossini's most popular successes, but he was never proud of it.

Before we parted, he begged me to visit him in Paris whenever I might find myself in the French capital; and I need hardly say how gladly I

of their time in following the arts. I myself in 1844 paid a visit to Kremsminster, a religious house commanding a magnificent view of the Danube and the surrounding country. There are every day many visitors, who, if they choose, may be regaled with an excellent repast. I remember my astonishment at the number of grand pianos in the monastery, and was glad to be able after dinner to acknowledge the hospitality of the Fathers by playing to them for some time. 
availed myself of that invitation on the first opportunity. Rossini received me with the greatest cordiality, insisting on my presence the following evening at his weekly (Saturday) reception. On my first visit to the house, I met the late Louis Engel, who used to read to Rossini his letters and newspapers, besides managing his accounts and acting as general secretary.

The Saturday receptions were of world-wide renown. Everybody in Paris who was anybody used to put in an appearance, amongst them being Alboni, the great dancer Taglioni, Jules Lefort (a celebrated and charming singer), and Gustave Doré, who invited me next day to his studio and to dinner afterwards at Bignon's.

How delightful the recollection of those evenings is to me even now I can hardly describe. Rossini himself did not appear in the salon, but remained seated all the time in his arm-chair. which was placed in a diminutive apartment - little more than an alcove, in fact-adjoining it. He conversed. however, all the time with some of his friends. Well do I remember the mortification of an English lady -a Miss Hamilton, godmother to my eldest daughter-because the friend who had introduced her insisted, as a strict Sabbatarian, on departing at twelve o'clock, to avoid any infringement of the Sabbath rule. 
Rossini gladly received callers at any time, but he would rarely pay visits himself. With the exception of an hour spent daily from one to two o'clock at the Palais Royal, he was always at home. His weekly receptions he supplemented by a dinner-party on his birthday, which, however, occurred only once in four years, the great composer having been born in leap year, on February 29. When he was seventy-two, he invited his friends to celebrate his 'eighteenth birthday.'

One of Rossini's witty sayings that recurs to me was at the expense of a very esteemed friend of mine, the late Prince Poniatowski. A charming man was Poniatowski-unassuming, invariably courteous, and in many respects gifted. For an amateur he possessed considerable musical talent. In fact, his song, the Yeoman's Wedding, enjoyed at one time extraordinary popularity in England. Poniatowski, I may further mention, was an intimate and loyal friend of the third Napoleon, whom he followed in his first exile, remaining in England until he was permitted to return to France.

Amongst other works, the Prince had composed two operas, one of which, through the influence of the Marquis de Caux, with whom he was very intimate, was produced by Frederic Gye at Covent 
Garden. This work, notwithstanding the appearance of Adelina Patti in the principal part, was not a success, and was, I believe, only once repeated.

The great dream of the composer's life, however, had been previously realized. It was to have one of his works performed at the Grand Opera in Paris, and one of the first acts of Louis Napoleon on becoming Emperor was to gratify his staunch friend's ambition by ordering an opera of his to be produced at the national Opera House. Poniatowski's excitement, on being informed of the Emperor's command, knew no bounds, and he at once went off to see his friend Rossini, to tell him of his good fortune. The composer of Il Barbiere, of course, congratulated him, and wished him all success.

Then the Prince explained that he was in some difficulty, as he had two operas by him, and did not know which of them was likely to take the most. Therefore he suggested that Rossini, with his wide experience, might advise him. Rossini acquiesced, and good-naturedly offered to hear the Prince play the two works over to him, but 'not both on the same day.'

On the following morning Poniatowski duly arrived, armed with a very bulky volume contain- 
ing one of the operas. Taking his seat at the piano, he played the work right through-a proceeding that occupied, as one can imagine, some considerable time. When he had finished, Rossini, whose patience was well-nigh exhausted, and who could never resist the temptation of making a joke, turned to the Prince, and quietly remarked :

'Maintenant, mon ami, je peux vous conseiller. Faites jouer l'autre.' (Now, my friend, I can advise you. Have the other one performed.)

A few days after Meyerbeer's death, a young and ardent admirer of his called upon Rossini with an elegy which he had composed in honour of his idol, to ask the maestro's opinion of the effort. Now, Rossini's regard for his late confrère had been none too cordial; but after the youth had finished playing the elegy over to him, he exclaimed:

-Well. if you really want my honest opinion, I think it would have been better if you had died, and Meyerbeer had written an elegy.'

On another occasion, Liszt having played to him one of his symphonic poems, he said :

'I prefer the other.'

'Which other?' asked the pianist.

'The chaos in Haydn's Creation!' replied Rossini, which shows how truly impartial was the composer in his caustic flights of fancy. 
Rossini never went to the opera or to any place of amusement, but he could not, for all that, resist the temptation of going to hear one of Wagner's works. It was Tannhäuser. Afterwards, when asked to give his opinion of the opera, he said :

'It is too important and too elaborate a work to be judged after a single hearing; but, as far as I am concerned, I shall not give it a second.'

A well-known Italian composer and conductor resident in London was accustomed at Christmastime to send Rossini a Stilton cheese, a delicacy of which he was very fond. On one occasion the gift was accompanied by an oratorio, which the donor had just written. Rossini's laconic letter of thanks (he never wrote more than two lines) merely said :

'A thousand thanks! I like the cheese very much.'

One day Rossini was visited by a very gentlemanly person, who desired to enlist his aid in procuring for him an engagement in the orchestra at the opera. Rossini met his request by saying that he had'no influence with the manager, and that, moreover, he knew nothing of the aspirant's capabilities, nor upon what instrument he performed. 



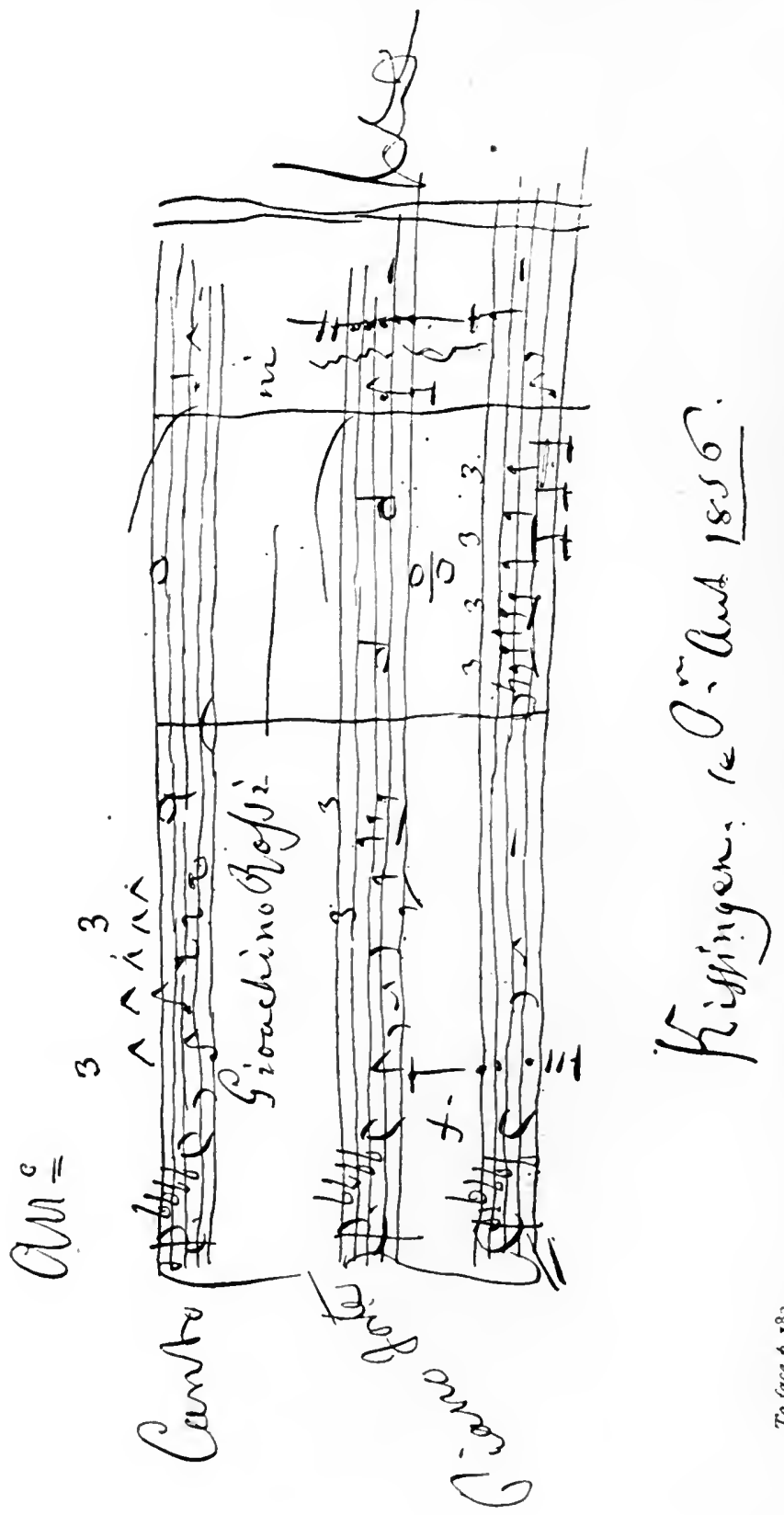

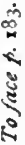


'The drum,' promptly replied the visitor, upon which Rossini said :

'I cannot possibly hear and judge you, for, of course, I have no drum in the house.'

' Oh, I brought one with me,' replied the performer; 'pray allow me to fetch it from the hall.'

Rossini, seeing that he was in for it, settled himself in his arm-chair, and said :

'What are you going to play?'

'Your own overture to Semiramide,' was the answer.

'All right ; pray begin,' proceeded the maestro.

Now, the very first bar of the overture contains a tremolo for the drum. This being duly performed, the player said :

'Now I have a rest of seventy-eight bars; these, of course, I will skip.'

'Oh no,' said Rossini, 'by all means count the seventy-eight bars; I particularly wish to hear those.'

The accompanying is a facsimile of some bars of music, together with the composer's autograph, which Rossini wrote in my wife's autograph-book. 


\section{CHAPTER XXVIII.}

\section{THE GARCIAS.}

The Garcia - Madame Viardot Garcia, the half-sister of Malibran-A linguist-Skill with the brush-The original Fides-An aged heroine-Residence at Baden-BadenAnd in Paris-A priceless manuscript-Manuel Garcia, singer and teacher-Jenny Lind's master-Professor at the R.A.M. - The Grand Old Man of music-His ninetieth birthday-Unfailing courtesy.

I HAVE been so fortunate as to witness, and therefore am able to describe, the débuts of most of the renowned vocalists of this expiring centuryJenny Lind, Alboni, Trebelli, Titiens, Patti, Nilsson, Piccolomini, Albani, Giuglini, and others.

I must not neglect to mention another remarkable singer, whom I frequently heard, and as often admired - Viardot Garcia. This lady was a member of one of the most celebrated musical families ever known. Her father was the Garcia,*

* For him Rossini wrote the part of Count Almaviva in Il Barbiere, which he 'created' at the first performance of that 
the greatest singer at the beginning of the century, though unremembered now; her half-sister, the gifted and never-to-be-forgotten Malibran; and her brother, Manuel Garcia, of whom I shall speak anon.

Viardot Garcia, peerless vocalist and consummate actress, was one of the most notably-endowed women of her day. Mistress of Spanish, Italian, French, German, and English, she spoke and wrote them all with equal facility. Possessed of considerable literary power, her conversation was delightful; and in all things, musical especially, her judgment could be safely relied on. She was also skilful with her brush, and a pianist of no mean capability. For her, Meyerbeer, in composing Le Prophète, conceived the part of Fides, and no such Fides has since been heard. In no other opera, to my knowledge, is the heroine an

best of all comic operas in Rome (18I5). There was an organized cabal in the house, and the opera was mercilessly hissed. How many operas, now among the most popular, have failed to please the public on first acquaintance! Meyerbeer's Huguenots, Verdi's Rigoletto, Gounod's Faust, and Bizet's Carmen, although unappreciated at the beginning of their career, have won their way to the forefront of popular esteem. Rossini's Guillaume Tell, by the way, with the exception of the glorious overture and a few isolated items. has never won the admiration of the masses, although connoisseurs were delighted with the entire work. 
old woman, for L.e Prophète is no love-story in the accepted sense. It tells, indeed, of a mother's love for her son; and Viardot Garcia invested the part she created with a living interest, which made it quite as attractive as that of the ordinary youthful heroine. How beautifully she sang her two arias, Ah, mon fils and Pietá, pietá, and how transcendently she acted in the Coronation scene, none who heard and saw her will ever forget.

Excellent as she was as Valentine in Lcs Huguenots, and many other dramatic rôles, I remember her particularly as Rosina in Il Barbiere (in which part, however, she was far surpassed by Adelina Patti), and as Adina in L'Elisir d'Amore. In these characters her manner was full of grace and charm, although it seemed to me rather artificial than natural.

The private life of Viardot Garcia after her retirement from the boards was devoted to teaching and training pupils for the stage. I visited her in I869 at Baden-Baden, where she had purchased a beautiful villa, to which she added a private theatre. After the Franco-Prussian War, however, her sympathy with the conquered nation (her husband, Monsieur Viardot, was a Frenchman) was such as to induce her to leave 
Germany. Her villa was sold at a great pecuniary loss, and she took up her residence in Paris, where her son has made a great reputation as a violinist.

Let me here instance a fact proving the devotion of this widely-gifted woman to art. During her sojourn in Germany, it came to her ears that the old-established publishing firm of André, in Offenbach, desired to sell the manuscript of Mozart's operatic masterpiece, the immortal Don Giovanni. This priceless relic had been on sale for some years, and, incredible as it may now appear, the authorities of the Austrian Museum, who, at any rate, might have been credited with better judgment, felt themselves unable to acquire it at the modest sum of 5,000 francs (about $£ 200$ ). That the powers directing our own gloomy shrine of antiquities in Bloomsbury likewise rejected the offer was at that date perhaps not very surprising. In these days when $£ 70,000$ is thought no great price to pay to secure a single picture for the National Gallery, so precious a document had surely not been lost to our nation. But one perusal of the sheets was sufficient to decide Madame Garcia, who became the owner of the manuscript without delay.

Her brother Manuel, of whom no one can 
speak except with feelings of veneration, is still amongst us, active at the ripe age of ninety-two. As a young man a great singer, he became in later days the most accomplished teacher whom, perhaps, we have ever known. Amongst his numerous pupils I need only mention Jenny Lind, whose early defects were discovered and remedied by Manuel Garcia, the result of his efforts belonging now to the history of musical art. This veteran singing-master was one of the army of musicians who found a home in London in 1848 , in consequence of that Revolution to which music in England owes so much. Echoing not irreverently the exclamation with which the Roman Church in the office of Holy Saturday apostrophizes the cause of Eden's disruption, we may say of that event which was so disastrous abroad, $O$ felix culpa! since it gave to England so many apostles of art, and saved us from the musical perdition which seemed at that time to threaten us.

Garcia, at his great age, still teaches all day long, devoting his spare moments to writing books on subjects connected with his art. He honours the Royal Academy of Music by remaining on the staff of its professors, who on the ninetieth birthday of the Grand Old Man of music 
presented him with a testimonial in recognition of his long and lasting labours. A great company of his friends and admirers gathered on a subsequent occasion (a year later) under his hospitable roof at Cricklewood to congratulate the veteran.

Long may Manuel Garcia be spared to us as an example of kindness and courtesy, as a man who always says and does the right thing in the right place, and at the right moment too. His advanced years serve not with him as a pretext for neglecting what he considers a duty, or as an excuse for withholding his presence from any function where it would be accepted as a graceful compliment. After a long day's teaching, and knowing that there awaited him on the morrow hours of arduous duty, he failed not to attend the receptions in honour of the jubilee of Dr. Joachim and Alfred Piatti. Nor could August Manns' seventieth birthday be observed without the cheerful, courteous, and ever-welcome presence of the patriarchal singer. 


\section{CHAPTER XXIX.}

\section{CHRISTINE NILSSON.}

A regrettable performance-Fall of a public idol-And rise of a new 'star'-Début of Nilsson in 1867-A beautiful Traviata-My companion's infatuation-Nilsson at $\mathrm{my}$ concert - The Mad scene from Lucia-A highlydramatic achievement--Some French rôles-And Swedish melodies-Happy suggestion-The diva's English farewell-Handsome emoluments- $A$ pleasant supper in Brook Street-Sims Reeves again-The singer's pledgeIts fulfilment-Letter from Grange Mount-Another from Nilsson.

Is I 866 an event happened in the operatic world which left a sad impression in the minds of all music-lovers who for years had entertained a fervent admiration for a beautiful woman and a most gifted and fascinating artist. Giulia Grisi, for many seasons the idol of opera frequenters, had some time previously made her final bow to the public; but now she arranged to give a few additional valedictory performances at $\mathrm{Her}$ 
Majesty's Theatre. Only one, however, took place, for reasons which struck all her admirers as infinitely pathetic. The great singer elected to appear in one of her most famous rôles-that of Lucrezia Borgia-and the utmost interest was manifested in the event, the house being filled to repletion by a most brilliant audience, anxious to welcome her back.

But what a disappointment awaited her aforetime worshippers! True, there was in the acting of the part much of the early dramatic force and intensity; but before the songstress reached the end of the first aria, Com' e Bello, it was apparent to all her hearers that hardly a trace of her once beautiful voice remained. Indeed, the whole performance proved a complete fiasco, with the lamentable result that the other representations which had been announced were not given.

I have already mentioned a similar mistakethat of Pasta in 185 -and could, indeed, quote others, but for a natural desire not to wound the feelings of any who may read these pages.

In the case of Grisi, at any rate, let her admirers try and forget that one error of judgment in the remembrance of the many artistic treats afforded 
them when the artist was in full possession of her wonderful powers.

The year that followed (1867) witnessed the triumphant début, at Her Majesty's Theatre, of Christine Nilsson-an event at which I was fortunate enough to 'assist.' It was, as many will remember, in La Traviata that the Swedish singer made her first appearance; and no one who was present on that occasion will have forgotten the extraordinary sensation she created. For two years previously the artist had been singing in Paris, where she was most favourably received and criticized. Of Nilsson's singular beautysingular, perhaps, by reason of its strong, almost masculine quality-I will say nothing now beyond recording the somewhat amusing effect it produced upon a friend-well known in the artistic world-who happened to be seated next to me on the night of her début.

At the conclusion of the first act, having expressed profound admiration of the voice and style, and, above all, the acting, of the new Traviata, I asked my neighbour whether he was prepared to endorse that opinion. Greatly to my amusement, and not a little to my astonishment. he replied in an outburst of rapture : 
'Her voice? You must not ask me yet; I cannot say. She is perfectly beautiful! I have not been able to take my eyes off her since she came on the stage, and I cannot see and listen at the same time. But what a beautiful girl !'

Yes, truly. But a beautiful voice, too-a voice of extraordinary flexibility, richness, purity, and, more than this, of remarkable individuality. It was always this peculiar timbre that I considered the diva's principal attraction. Had I, after a number of years, and blindfolded, heard her again, I should, by reason of this 'individuality' of voice, have exclaimed at once, 'That must be Nilsson.'

Then, as an actress she was wholly original. There was nothing conventional about her acting, and this was of great assistance to her in many parts. Personally, I never cared for her Traviata as much as I did for Patti's; but it was a magnificent creation, all the same. In any event, that performance alone made her the one theme of conversation, and even my enthusiastic friend forgot his admiration for her personal attractions in his astonishment at her admirable vocalization and acting. 
Two days after this memorable début, Nilsson sang at my annual concert in St. James's Hall, when she gave the Mad scene from Lucia. The success was instantaneous, and she at once became as great a favourite in the concert-room as she was on the stage. Even on the concert-platform her movements were dramatic, and the charm of her singing was enhanced by gesture and facial expression. In a word, she 'acted' the songs she interpreted.

Incidentally I may here mention that for many years subsequently Nilsson appeared, under my auspices, in London and in Brighton; and I also 'starred' the diva on a provincial tour through England, Scotland, and Ireland, for which I paid her $£_{3}, 000$.

Nilsson's lyrical triumphs were many. In Lucia she was extremely good; alike in looks, singing, and acting, she was an ideal Marguerite in Faust; while as the heroine in Ambroise Thomas's melodious opera Mignon she was most fascinating. But perhaps her very best creation was Ophelia, in the same composer's Hamlet.* It was a

* It was in 1868 that Christine Nilsson enraptured the public with her memorable creation, but it was at Covent Garden, and not at Her Majesty's Theatre. At this time the 
unique performance, and proved an artistic treat of the highest order. The opera, be it confessed, was not to everybody's liking, but the Swedish melodies, which the composer incorporated in the score, were, as sung by Nilsson, immensely effective. Her interpretation of the Mad scene, too, was a real inspiration.

Some years after Madame Nilsson's (then the Comtesse de Miranda's) retirement from public life, I wrote reminding her of the fact that, unlike most distinguished artists, she had never taken formal leave of the public; and as she had appeared for the first time in a concert-room in this country under my auspices, I should very much like her to bid farewell to her English admirers at a concert of mine. I suggested two appearances in the Albert Hall, a proposition to which she readily acceded. There only remained to be settled the little matter of terms-a mere trifle, as all concert-givers know-and the sum agreed upon was $£_{1,000-£ 500}$ for each appearance. These concerts, which were among the most

two managers had joined hands. Her Majesty's was closed, Mr. F. Gye and Mr. Mapleson had combined the two companies, and the performances took place at the former's establishment in Bow Street. 
successful I have ever given, took place in June, I888. On each occasion the enthusiasm of the audience was something to be remembered.

After the final concert, my friend Mrs. Brydges Willyams gave a 'farewell' supper to the diva at her house in Upper Brook Street, to which many celebrities in the world of music and the drama were invited, Henry Irving being a prominent guest. Christine Nilsson sat next to me, and in course of conversation, the name of our mutual friend, Sims Reeves, cropped up. The diva happened to remark that she wondered when the prince of English tenors would take final leave of the public, and added that, whenever he did so, the event ought to be a notable one. I agreed with her, observing that every artist known to fame in Europe ought to rally round the illustrious singer on such an occasion, whereupon the artist who had just bowed for the last time to an English audience, and retired crowned with laurels, said that, although she was firmly resolved never again to accept a professional engagement, she would, if asked, come from any part of the world to assist at a Reeves farewell.

When the time drew near for the memorable 
64.

thonde lo the Dregine the froras:

I fhusture, the haphictuily consutid frome for me as

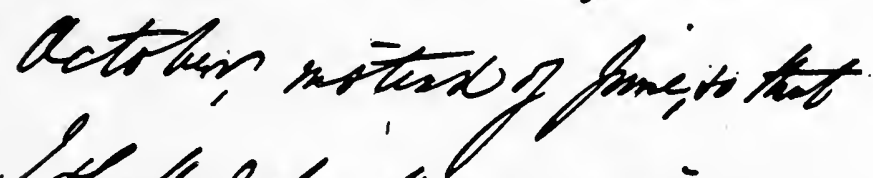
Strall fet all ay porronene

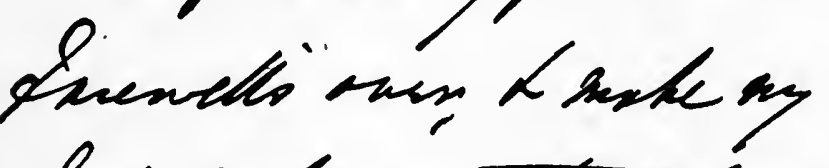
final. how at the thest

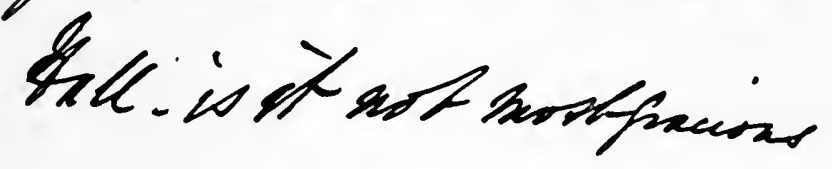




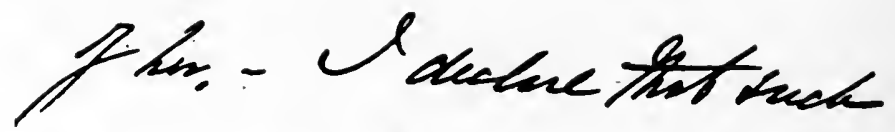
ane ack from a histasatiote. - ot oced an asthoti. a muck luve datisifectiry. Opativin thin all the Tervy 9 even

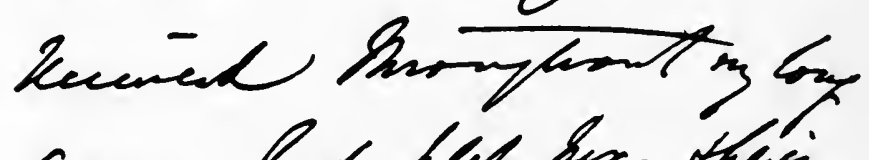
caver. for llef. her - the's a Anlijg. Ot a is gror arife.

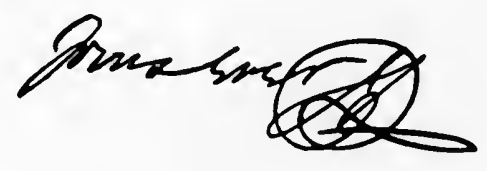

To face p. 197. 
valedictory appearance in the Albert Hall (May I I, I89I)-an appearance which, but for circumstances which every admirer of a gifted artist and a good friend sincerely deplores, would undoubtedly have been a final one-I wrote to the Comtesse de Miranda, reminding her of the promise she had made some years previously, and telling her that it would add considerably to the éclat of the occasion if she could fulfil it. She at once replied, intimating her willingness to appear once more before a London audience in order to meet the wishes of her old friend and fellow-artist ; and thus it happened that conspicuous among the distinguished singers who did honour to the 'public darling' on that eventful evening was Christine Nilsson. It was a graceful act which needs no comment, save a passing allusion to the fact that everybody who was present was impressed not a little by the strength and comparative freshness of Nilsson's voice at a time when most singers would have failed to produce any impression whatsoever.

Apropos of this appearance of the cantatrice, some difficulty arose in regard to the date on which the concert was to be given; I forget the circumstances, but I know they involved some 
correspondence between Nilsson and the great tenor, from whom I received, in reference to the prima donna's good nature, the letter of which a facsimile is here given.

I also give a facsimile of a letter from Christine Nilsson. 
Gandradeundre
1886

Cher Honseiun Thabe;

Herci de uar amadaler

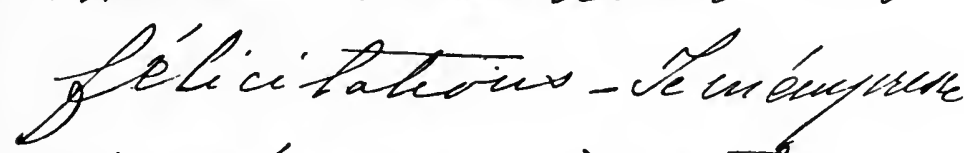

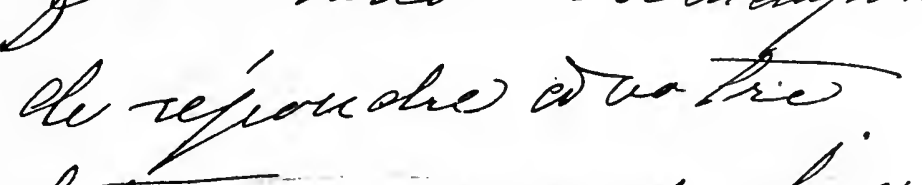
Lethe jown naw olice In il in ést hieir slifficile de unur artives seis a firient ti " terair 
en An gleterre ffubuno trodeacie, mayt dayey certain que fe un tranue to ax tru anpofigasde s'aublie of oflicitation prour pa dideforov -u sle adf fercersos a Brienterte

tegrfys, fher thouscice Pafturance de roos Hentuiues destriensúv

To face p. 198. 


\section{CHAPTER XXX.}

MARIO.

Farewell performances in $187 \mathrm{I}-\mathrm{A}$ memorable series-The great tenor in La Favorita-A moving scene-Mario in private life-Pretty compliments to a little girl-The calumet of peace-Statesman and artist-Mario, the friend of Cavour-Some facts about artists' salariesGenerosity of Mario-The waiter in luck-Itinerant musicians rewarded-Recognition from 'Sir Hubert'-A well-deserved testimonial-Kindness of Sims ReevesMario befriended by Victor Emmanuel-All roads lead to Rome-William Cusins-Queen Victoria's tribute to a great singer.

I HAYE spoken in the course of these reminiscences of many débuts, and of two unfortunately disastrous leave-takings, those, namely, of Pasta and Giulia Grisi. As regards the latter, my task was one of no little difficulty, for I have been privileged to witness the frequent triumphs of an artist highly gifted and admirable beyond words. Her husband, Signor Mario,* the only legitimate

* This name was assumed. The famous singer's proper patronymic was Conte di Candia. It is curious, by the way, that the greatest Italian singer and Cavour, the greatest Italian statesman, were born in the same year, 1810 , and as youths were close friends. 
successor of Rubini, was engaged by Mr. F. Gye in $187 \mathrm{I}$ to give some farewell performances, and repeat a number of his most successful impersonations. Mario's final appearances made that season for ever a memorable one. Never before, and certainly not since Mario's time, has such a combination of perfections been seen in one individuality upon any stage. Beauty of voice and person, rare histrionic powers, manners so fascinating that even the diffident felt themselves at home with him on a first introduction-these were some of the attractions which were merged together in Mario, the incomparable tenor.

When he came to take his farewell of the stage, there remained (truth compels me to confess) very little trace of that once matchless voice of his, and yet there seemed to linger in his perfect phrasing an ineffable charm to be found in none of his younger and more vigorous rivals. Of his series of final appearances, I will single out one for special mention. the night on which he chose to impersonate for the last time Fernando in Donizetti's La Favorita. In the opening numbers he was in indifferent voice, but warming to his work as the opera proceeded, he reached a climax in the scene in which Fernando discovers the relations existing between Leonora 
and the King, his acting, as he broke his sword across his knee and cast it at the monarch's feet, being so full of power, and at the same time so completely natural, as to excite the audience to the highest pitch of enthusiasm. The whole house literally rose at him, irresistibly moved by acting which was worthy of the German Devrient, the French Lemaitre, the Italian Salvini, or the English Henry Irving.

Even now, when from time to time I meet friends who were present on that long-remembered night, the conversation naturally and invariably turns upon that wondrous performance. In private life, I may mention, Mario possessed equal charm of manner. Admired on the stage, he was beloved in the domestic circle.

Mario was an inveterate smoker. Whether at the opera or a concert, he indulged his fondness for tobacco all the time in which he was not actually before the public. Except at meals, indeed, I never saw him without a cigar, and if he awoke in the night he immediately lit one.

Two reasons stood in the way of Mario's amassing a fortune, such as singers not unfrequently do in these later times. In the first place, followers of his profession were then remunerated on a scale differing much from the extravagant rate which 
prevails at present. The highest fees he ever received were those paid to him by Mr. Gye for the farewell performances to which I have just alluded, his terms being $£ 600$ for each month of ten representations. This was a mere $£ 60$ a night (I am almost positive I am not labouring under a mistake as to the amount he received).

In the second place, Mario was quite exceptionally generous, not to say lavish. As an instance of this I may recall that I was with him once at the Old Ship, Brighton, when he ordered a shilling cigar, in payment for which he handed the waiter half a sovereign, and magnanimously refused the change. The waiter did not object!

On another occasion I was talking to him while he breakfasted at the same hostelry, when our conversation was disturbed by a street-band. Mario sent them out a sovereign. Such, I was told, was his invariable custom.

With such prodigal habits, it was not surprising that the great tenor made no provision for retirement from public life. He had, however, many friends and admirers in generous and grateful England. A concert was organized in order to raise a testimonial to him, a galaxy of his professional brethren and sisters vying with one another to do him honour. Among them was 
Sims Reeves, who, deprived by severe hoarseness of the pleasure of singing for his friend, most liberally sent a cheque for $£$ Ioo towards the fund.

The King of Italy gave Mario an appointment as custodian, I believe, in some library. or museum. His duties were not very arduous, but the stipend attached to them was sufficient to enable him to spend his declining years in Rome, where he ended his days in peace and quietude, unassailed by care. Visits from his English friends afforded him the keenest delight. With them he was never tired of talking about his former life in England, in which country, he was accustomed to say, he had passed his happiest days.

In I 888 Mr. (afterwards Sir William) Cusins spent the winter in Rome, and called several times on Mario. But one morning he was informed that his old friend could not see him. Mario was dangerously ill, and in two days (on December II) he was no more. Telegraphing the news to London without delay, Mr. Cusins received a command from Her Majesty the Queen to represent her at the funeral, and to lay a wreath on the coffin of the admirable artist, whose supreme gifts had so frequently delighted her.

My eldest daughter, then a little girl, having given him a flower on the occasion of his singing 
at one of my Brighton concerts, he embraced the opportunity of writing in my wife's album the lines of which I append a facsimile.

Appended, too, is a compliment penned by Giulia Grisi. 
Lundey

Dew Sur Kube'

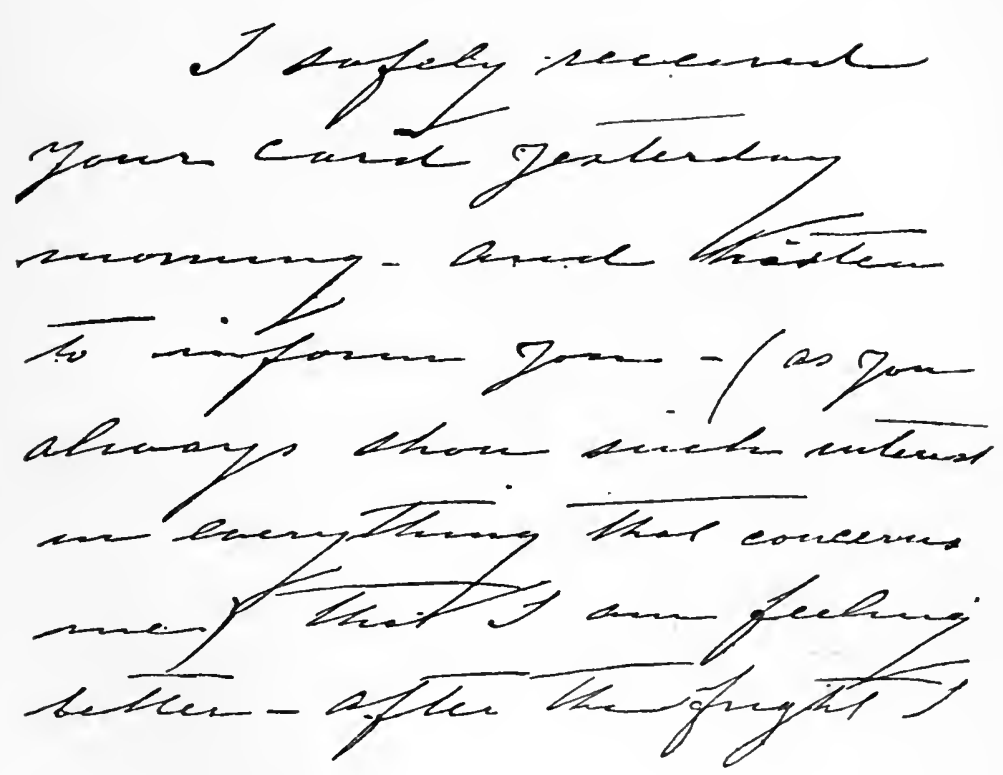




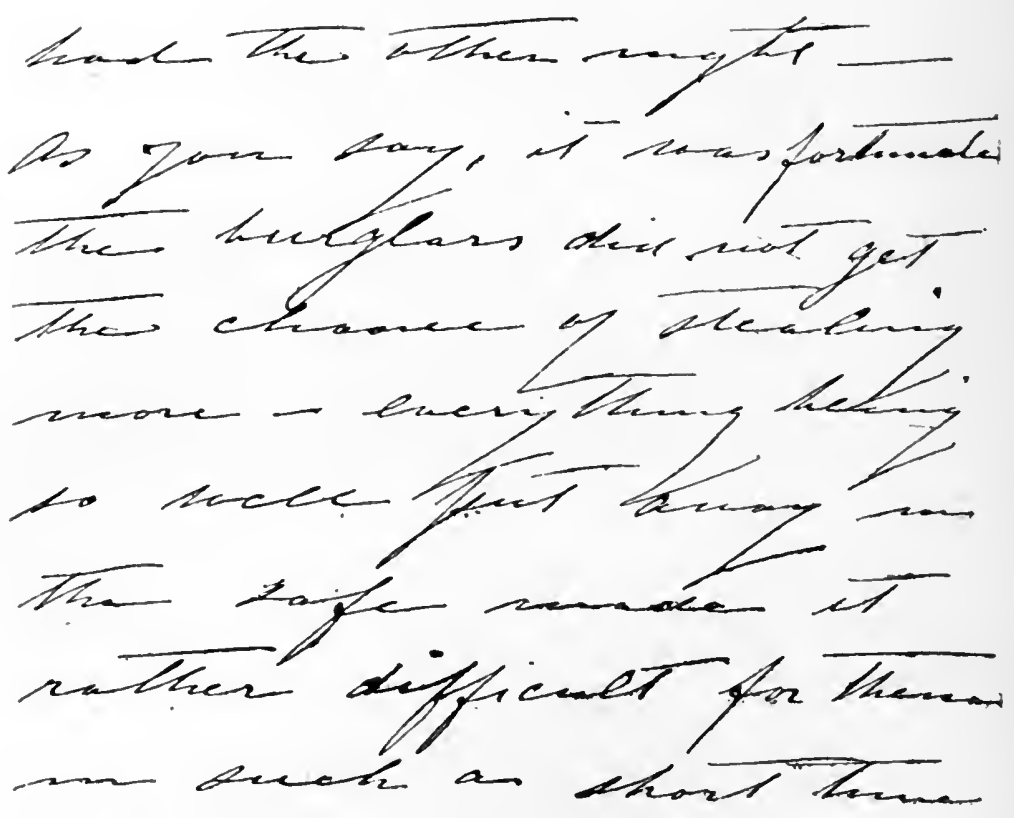

to get at any y say 
waluakles - I supporse the

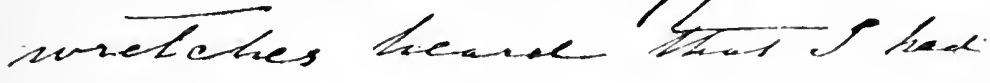

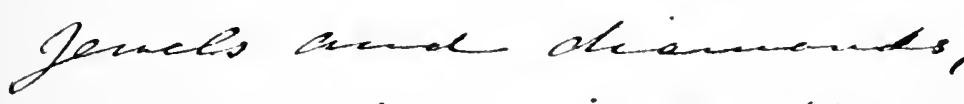

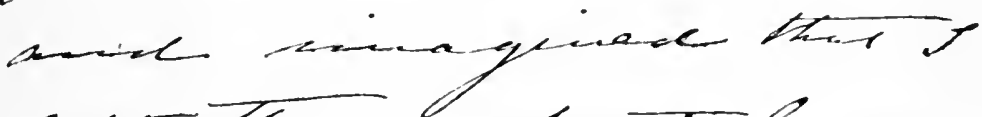

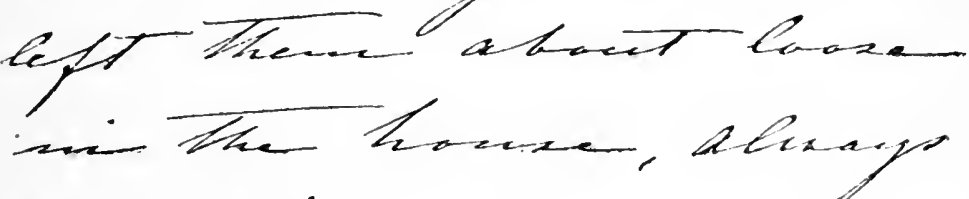

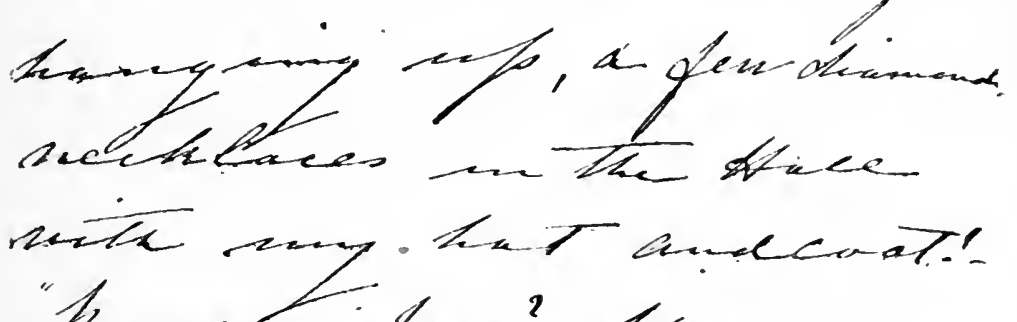

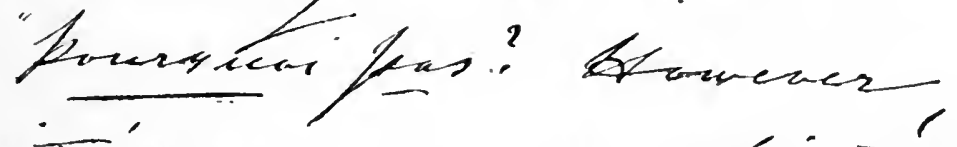

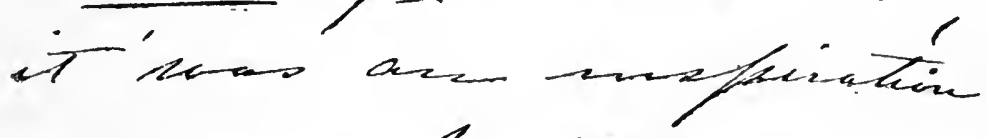

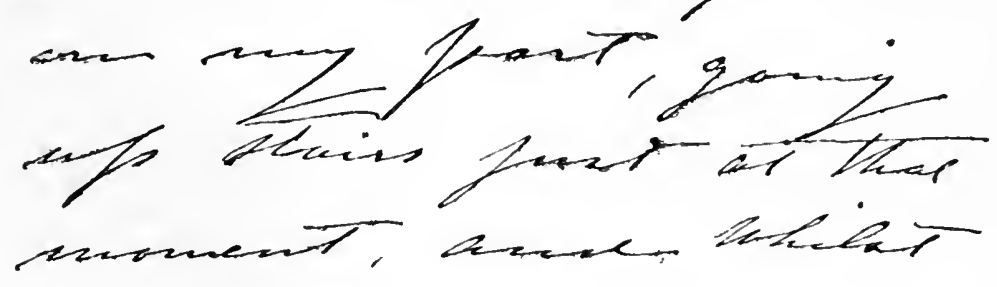




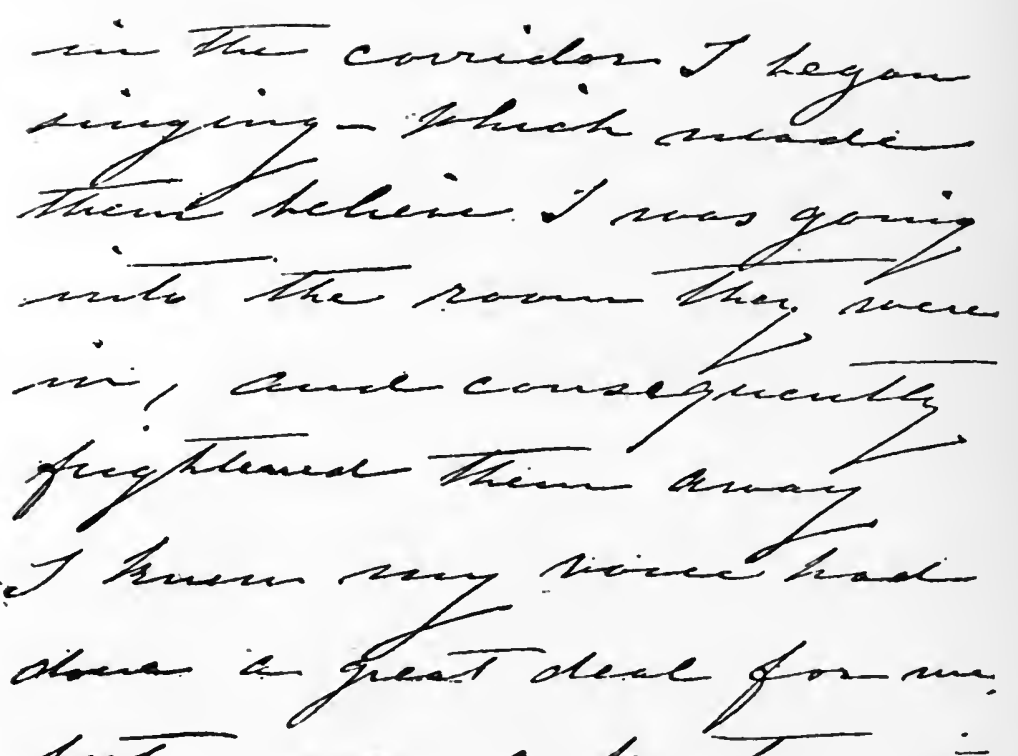
hat newer eypecta-e it Rovale

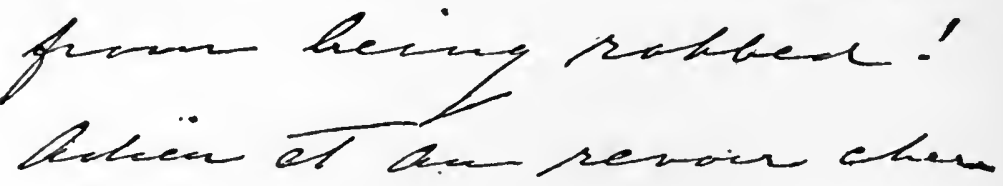

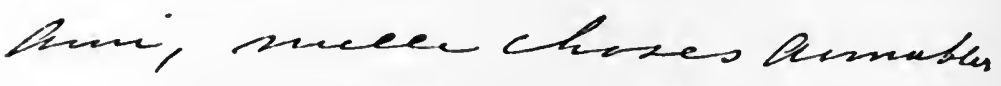
a' hithe chamentergancele 


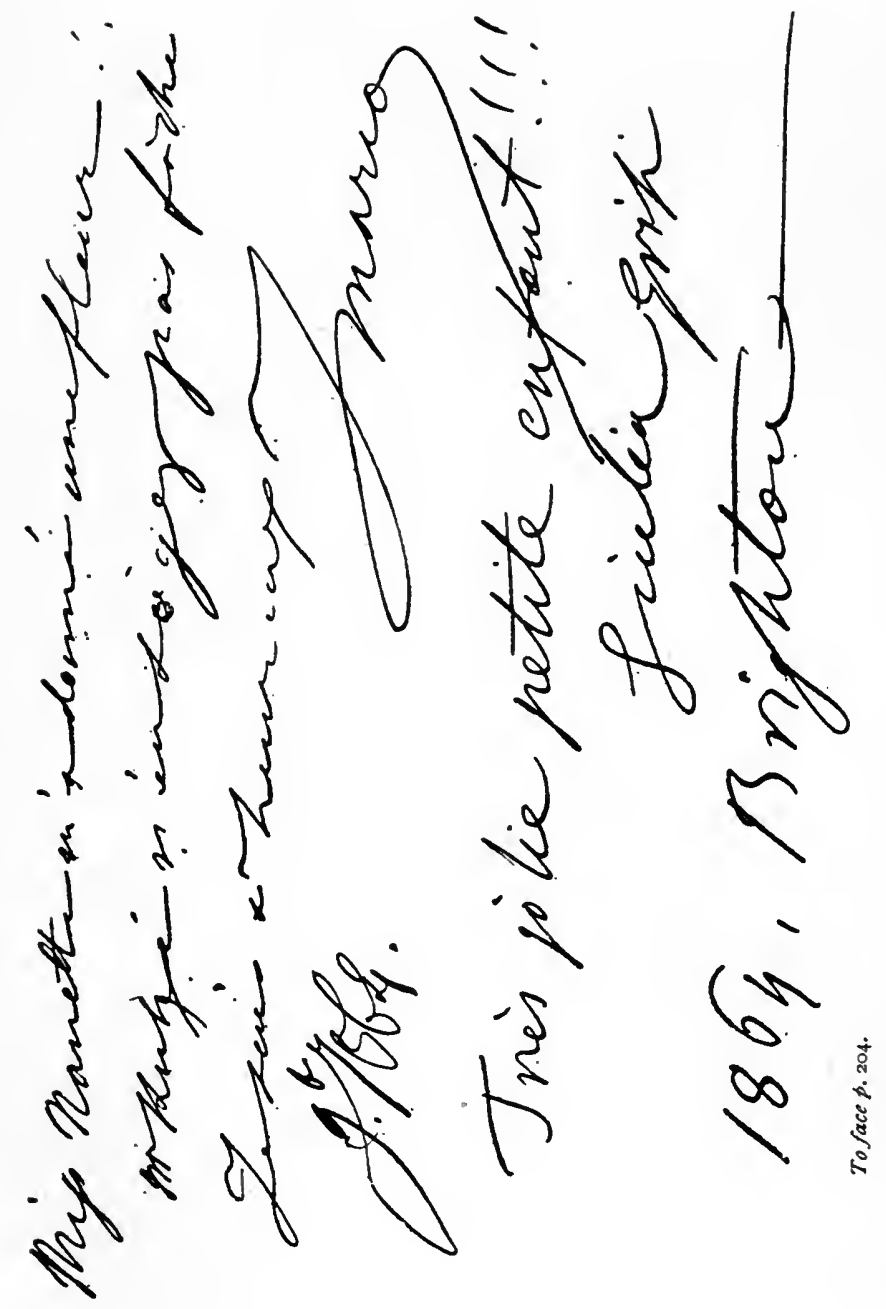





\section{CHAPTER XXXI.}

EMMA ALBANI.

Paris and the war of $1870-$ Marimon-Marie Roze-Campanini-Two notable exponents of Bizet-The musical event of I 872-A new Amina-Albani's début-A golden night at Covent Garden-A conscientious studentCatholicity of taste-The diva's Desdemona-Success in oratorio-The Golden Legend-A great festival singerAlarming incident at a benefit performance-The prima donna injured-'All's well.'

THE earlier portion of the decade which opened with the year 1870 was to a great extent overshadowed by signs and portents of the FrancoPrussian War, its tragic close and the dire sequel which attended it in the siege and partial destruction of the world's fairest city, the home of art and of artists. Few in the world of music were the souls untinged with sadness at this untoward event; for who can ever forget that Paris has sheltered and fostered foreign artists by the score, that her glorious Conservatoire has sent mis- 
sionaries of music to the uttermost parts? Certainly not we in England, who, in domains both classic and 'popular,' owe so much to the genius of Gounod, Auber, Massenet, Bizet, SaintSaëns, and a host of others, whose strains have become as familiar to us as to the people of the beautiful capital on whose ears they first fell.

Nor were years so pregnant with political changes wholly uneventful in the world of music. Of Signor Nicolini's first appearance in $187 \mathrm{I}$, I have already spoken. In the same year Mademoiselle Marie Marimon also made the acquaintance of the English public. The succeeding season was prolific in 'stars.' Marie Roze arrived in 1872 , and was destined to become as great a favourite here as she had been for years in Paris, where her beauty and talents as actress and singer had secured for her gratifying success. She long retained her place in the esteem of amateurs, by whom her Carmen, in particular, was rightly regarded as an impersonation at least comparable to that of Minnie Hauk.

About the same time Signor Campanini appeared on the English stage, fully confirming the good opinion formed of him in Bologna as Lohengrin. For his London début, he elected to appear as Gennaro in Lucrezia Borgia. His was a genuine 
tenor voice, which he used in a thoroughly welltrained manner. Of all the characters he undertook I preferred his Don José in Carmen, and I doubt even now' whether it has ever been more finely played. After several seasons, he crossed the Atlantic, his success with our American cousins being so great that he was induced to take up his residence among them. Some time ago he returned to England, but not to the operatic stage. He contents himself at present, I believe, with concert appearances.

The great musical event of 1872 has still to be recorded. I allude to the first appearance in England of one of our most gifted and popular vocalists, Emma Albani, who, like Patti and many others before her, selected the part of Amina in La Sonnambula, in which to make her initial bow to a very brilliant audience.

The night of her welcome was a golden one in the annals of Covent Garden. The great house was filled with earnest and observant listeners, gathered there to behold the rising of a new luminary in the operatic firmament; and none could for a moment doubt that the advent of Albani was that of no mere brilliant albeit ephemeral star, but of a planet come to stay. And time has confirmed that opinion. Albani 
has been with us for nearly a quarter of a century, and is now more firmly established than ever in the affections of the public. For, like a true artist, she has never allowed herself to rest in achievements with which her admirers were perfectly content, but has continued her studies, conquering difficulties, and acquiring fresh perfections, until she has reached a standard of supreme exceilence.

Another characteristic of Albani's, shared with a comparatively limited number of vocalists, is her devotion to every branch of music. She finds as great a pleasure in instrumental performances as she does in vocal displays. Combining with rare intelligence unusual capabilities for assimilation, she is easily influenced by all she hears, and it is consequently evident to observant amateurs who listen to her that she is no mere singing-bird, but a mistress of her art.

A nother distinguishing feature in Albani is the catholicity of her taste. She delights as much in the classic and severe manner of the older masters as she does in the advanced style of writers of the ultra-modern school. She is as appreciative of the works of Bach, Handel, Haydn, Mozart, and Beethoven, as she is susceptible to the melodic influence of the Italian school as 
represented by Bellini, Donizetti, and Verdi. Nor has she neglected the 'music-drama,' her studies of Gounod and Meyerbeer being supplemented by a close acquaintance with the scores of the Bayreuth master. In a word, she has kept pace with the times, well abreast of musical development in every legitimate sphere.

It would be difficult in a répertoire so comprehensive as that of Madame Albani to point to her most notable triumphs, but those who, like myself, have watched her career with unabating interest, would perhaps single out her Desdemona as a performance instinct with poetry and legitimate dramatic feeling; while her magnificent rendering of the Liebestod scene from Wagner's most advanced opera has caused regret that no opportunity has as yet occurred for her appearance in Tristan und Isolde.

In oratorios and cantatas, Albani shines with equal lustre, her intuitive devotional fervour, doubtless, contributing much to her success in this branch of art. Nothing can surpass her singing in the Messiah, Elijah, the Creation, and the Hymn of Praise; and I feel certain that the composer of the Golden Legend (a work which even at this date may almost be called immortal) will readily bear me out if I say that her render- 
ing of the soprano part has not so far been rivalled. No provincial 'festival,' assuredly, is complete without her presence, for not only is she peerless in the interpretation of sacred works, but she takes the greatest possible interest in the new compositions which it is customary on these occasions to launch on the stormy sea of public opinion. With Albani the study of the works of native writers is a labour of love. Small wonder, then, if they are anxious at all times that their melodies should first fall from the lips of so distinguished an ornament of musical art.

I give here a letter which Madame Albani wrote to my daughter. The incident referred to happened at Covent Garden Theatre on the occasion of a benefit performance given to the diva, when one of her admirers threw upon the stage a square box containing a diamond pendant. The singer was in the act of collecting her floral trophies, which were strewn over the stage, when the case, which was clumsily thrown, struck her forehead. At the moment it was thought that the heroine of the evening had been the victim of a malignant attempt, but happily this proved to be an erroneous impression. 


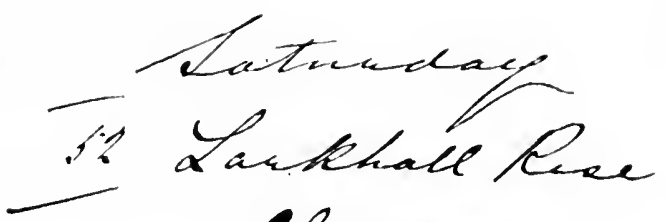

Clapkaces.

tuy deas hues Kult.

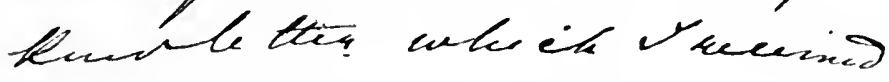
the forit the movising. and news glad to en that

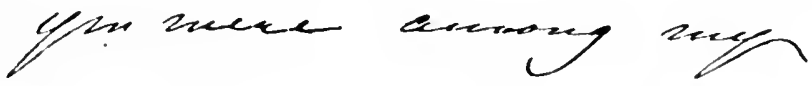

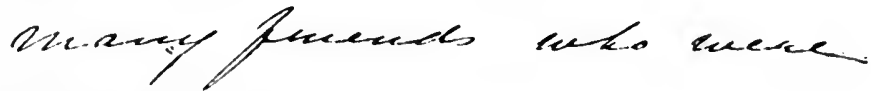
Ro Heren to us.

I was nat woweth twex ande a bltwenth ofelx 
the blown meny rumert ax the nawnewet, of hece

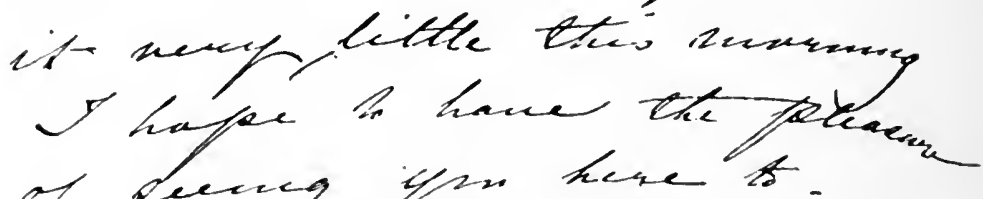
of Revang ysu here to. Revationes.

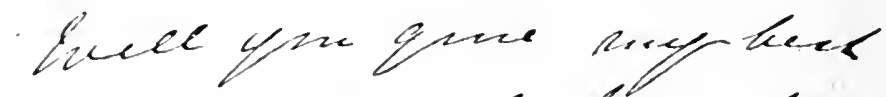

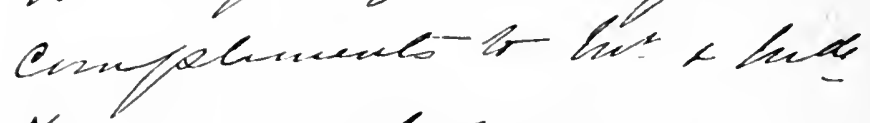
Fute awd belene were.
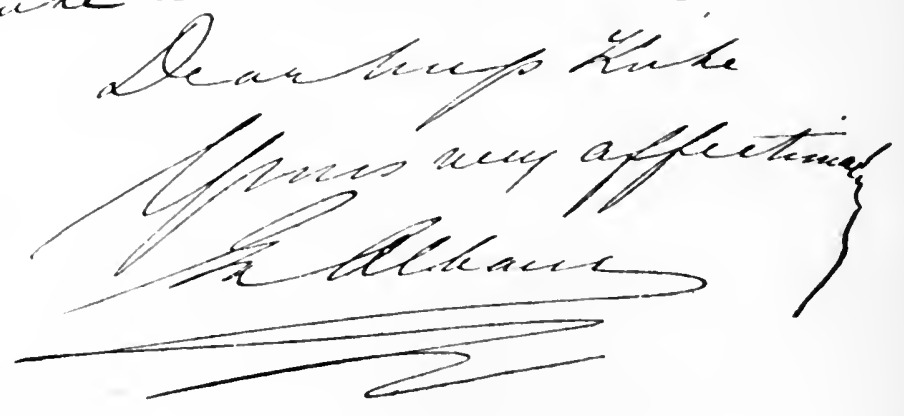

To face p. 210. 


\section{$[211\rceil$}

\section{CHAPTER XXXII.}

\section{ANTON RUBINSTEIN.}

His magic touch-Liszt's first receptions dimmed by 'Thalberg - England ripe for Rubinstein-Oftener heard than Liszt -First recitals at Hanover Square Rooms in $1852-$ Twenty-four years later at St. James's Hall-OvationsHistorical recitals in Paris-Free admissions to studentsRepeated in London, 1886-Charity concert-Generosity -Compositions not yet fully appreciated-Rubinstein's private life-Ennobled by the Czar-Dislike of ceremony - Hatred of solitude-Fondness for cards-Music after dinner-His friend Dr. Max Schlesinger-Rubinstein's superstitions-Dilemma at Edinburgh-Another poor musician-The difficulty solved-His pithy replies-Likeness to Mr. Bradlaugh.

Who among English amateurs will ever forget the spell exercised in our musical world by the magic art of Rubinstein? How many of the fortunate people who were present at those wonderful afternoon recitals of his would admit that on any subsequent occasion they have experienced quite the same kind of emotion as that which stirred them as he played? No pianist, at any 
rate, had ever succeeded in arousing our enthusiasm to such a pitch ; for Liszt, when first he came to England, played to people who were Thalberg-mad, and for the time incapable of understanding and appreciating even his incomparable gifts. Had the king of pianists delayed his coming for a decade, it would, I venture to say, have made all the difference in the world.

But in later years England was ripe for Rubinstein, albeit his genius met here with a recognition less speedy than that accorded to it on the Continent. Once bestowed, however, that recognition differed neither in quality nor in degree from the esteem in which the great Russian musician was held throughout the length and breadth of Europe. Rubinstein afforded English people many more opportunities of hearing him than his friend and predecessor, Franz Liszt, who soon tired of playing in public, and seldom broke through his routine of teaching and composition, except in the cause of charity. Rubinstein, however, had this in common with Liszt : he was an infant prodigy who fulfilled all the expectations justified by the promise of early years.

His first series of recitals in London took place at the Hanover Square Rooms in 1852 . The audiences, small in the beginning, were astonished 
- somewhat bewildered, perhaps - but inexpressibly delighted. His fame flew from lip to lip, and the next series was eagerly awaited.

Rubinstein came again in 1876 , this time to St. James's Hall, where he played to enraptured audiences who had fought for guinea tickets and bought them at a premium. Both the Philharmonic societies secured him for their concerts, and he played at the Crystal Palace, conducting also several of his great orchestral works. His performances met with no mere applause; nothing less than veritable ovations could express the appreciation which they evoked. Audiences rose as one man and cheered him to the echo. The right chord had been touched, and English phlegm for once made way for wild enthusiasm.

In I 886 Rubinstein gave in Paris four historical recitals, in which he exemplified the progress and development of pianoforte compositions, his first programme being devoted to pieces written in styles more or less archaic, while the final one was composed of the very latest modern works. The success of these recitals was unequivocal, the demand for seats being so unprecedented that not a single free ticket could be issued. Rubinstein, however, was anxious that students who could not afford to pay should nevertheless profit by hearing 
his interpretations of styles both ancient and modern. He therefore repeated the four recitals for the benefit of professors and pupils, and these only were admitted, no tickets being sold.

From Paris he came once more to London, where he repeated the four historical programmes with equal success. He also gave an extra concert for the benefit of some charitable institutions, whose claims upon him he was as little able to resist as the importunities of the deserving (and, be it confessed, the undeserving also) who at all times sought his pecuniary aid.

As a composer, Anton Rubinstein justly holds a high rank, though some may be of opinion that the due appreciation of his works is as yet in its infancy. His operas and more ambitious orchestral works may perhaps never attain popularity; but some of his pianoforte concertos, all his chamber and pianoforte music, will live-in fact, his sonatas for pianoforte and violin, pianoforte and violoncello, his trio, and many other works, may be considered classics.

In private life he was held in warm regard by everyone who was privileged to know him, for he was unaffected, lovable, and generous to a fault. His affection for his country was boundless, and he greatly appreciated the honour which he re- 
ceived when ennobled by the Czar, although, by reason of his modesty, he never used his titles. His dislike of ceremony was, in fact, so intense that not only would he never dress for dinner unless absolutely compelled, but he would not tolerate the appearance of other men in evening attire, either at his own or his friends' tables. As a case in point, I may mention the following incident :

Our mutual friend Mrs. Goetz, having arranged a dinner in Rubinstein's honour, reminded me that I must on no account wear my dress-suit, for were I to do so, her illustrious guest, who never observed such formalities, would be quite capable of quitting the table. On the same evening, however, the Austrian Ambassador was to hold a reception, to which I had been bidden. In order, therefore, to avoid wounding Rubinstein's sensibilities, and at the same time to secure my arrival at the Embassy at the appointed hour, I was obliged to take my bag and change my clothes at Mrs. Goetz's, after dinner.

But if this wonderful man disliked ceremony, he positively hated solitude, and, except during the hours devoted to practice and composition, would never be alone. $\mathrm{He}$ at no time sat down to a meal by himself. His friends were with him 
at breakfast and luncheon, and in the evening his hospitable board was so well attended that the gathering often assumed the dimensions of a regular dinner-party. The repast, except on state occasions, was invariably followed by a rubber of whist, of which Rubinstein was passionately fond. The game over, the master of the house, unasked, would often sit down to the piano and charm the company ere they departed.

Every Friday, when in London, he was accustomed to dine at the house of Dr. Max Schlesinger, whose friendship with myself dated from our early days in Prague. Having practised medicine with success, he abandoned it after some years in order to devote himself to literary work, and in particular to journalism, in which he speedily won his spurs. Coming to England, he was made correspondent of the Kölnische Zeitung, and several other leading German papers. He also founded a journal-the English Correspondence. He was one of the most gifted, and at the same time one of the kindest, of men. His Friday receptions were most pleasurable musically and otherwise. Here one met distinguished persons of all spheres, and the company always seemed to emulate their charming host and hostess in setting aside all pretension and affectation, thus feeling thoroughly 
at home. Dear, good, kind Max Schlesinger will always be remembered with affection. His wife, in every way worthy of her amiable and clever husband, is still happily with us.

To return to Rubinstein. Like many Russians, he was extremely superstitious. Nothing, for instance, would induce him to remain in company where he was one of thirteen. For example, his concerts were usually followed by one of his favourite informal dinner-parties. Being in Edinburgh for a recital, he had invited thirteen friends to dine with him after the performance, but at the last moment one of the guests found himself unable to attend. Consternation reigned for at least half an hour in bureau and kitchen, and in the drawingroom, too. The chef had visions of a spoilt dinner, the hotel proprietor felt his reputation might be compromised, and the guests were wondering how it would all end, when a band began to play in the street below.

On hearing their cacophonous strains, a bright thought flashed across Rubinstein's mind.

'There's no help for it,' he exclaimed. 'We must spoil the homogeneity of the performance, and give one of the musicians a supper for his song.'

Not realizing what he meant, the guests evinced surprise; but the mystery was cleared when the 
inspired host, ringing for the waiter, instructed him to convey to the itinerant players 'the compliments of another poor musician,' and say he would deem it an especial honour if one of their number would come and dine with him. The waiter was probably a Scotchman, or else he would have construed so unusual a request as a piece of harmless pleasantry. As it was, he promptly carried out the order, and, greatly to the amusement of the company, returned with one of the bandsmen. The situation was saved, and probably the street musician least of all regretted the absence of the original number thirteen.

Rubinstein's replies were often quaint and pithy, as the following instances will show:

Going one summer to Marienbad for the cure, he was, in obedience to the fiat of his physician, who had ordered rigid abstention both from writing and from playing, without a piano. At the termination of the course, however, he was solicited to give a concert for the benefit of the hospital. With Rubinstein such a request was tantamount to immediate compliance, for he never listened in vain to an appeal made in the interests of charity. He merely asked that a pianoforte should be sent to his room, in order that he might, so to speak, remove the rust from his finger- 
joints. On the arrival of the instrument, he set to work at once, but he had hardly played for a quarter of an hour, when an Austrian Countess, who was installed in the rooms overhead, sent him a note to this effect :

'Sir,

- People come to Marienbad for rest and quiet, not for the purpose of hearing hammering and strumming on the piano. If you are determined to make such a noise, try, at any rate, not to play so many wrong notes.'

Rubinstein merely wrote in reply:

' Madai,

'I am sorry my wrong notes should have tormented you.

'Anton Rubinstein.'

The lady's surprise and consternation on learning the identity of the illustrious performer is best left to the imagination.

Among Rubinstein's visitors was one day a young and beautiful orphan girl. Her father had left her quite unprovided for, although he had found means to educate her as a lady. Certain friends had assured her that her musical talents 
were worth cultivating, and she accordingly intended to enter the profession. Before coming, however, to a final decision, she obtained an introduction to Rubinstein, with a view to seeking his advice. Having heard her play, he saw at once that she had mistaken her vocation, and told her, as kindly and considerately as the circumstances permitted, that he could not counsel her to spend money and time in pursuing a phantom. The poor child was broken-hearted, and wept bitterly, exclaiming :

'What am I to do? What am I to do?'

Rubinstein took her hands, and, looking her in the face, quietly observed :

' My dear young lady, get married.'

Rubinstein evidently was not a reader of the I.ondon Charivari.

I wonder if there are many people living who remember that the illustrious pianist bore a striking resemblance to the late Charles Bradlaugh. So marked was this likeness, that on the occasion of a visit he paid some years ago to Dublin, in company with his friend Mr. Vert, Rubinstein, who was 'spotted' on arriving by an eagle-eyed reporter, was mistaken by the latter for the Member for Northampton. The result was that the newspaper he represented, with true 


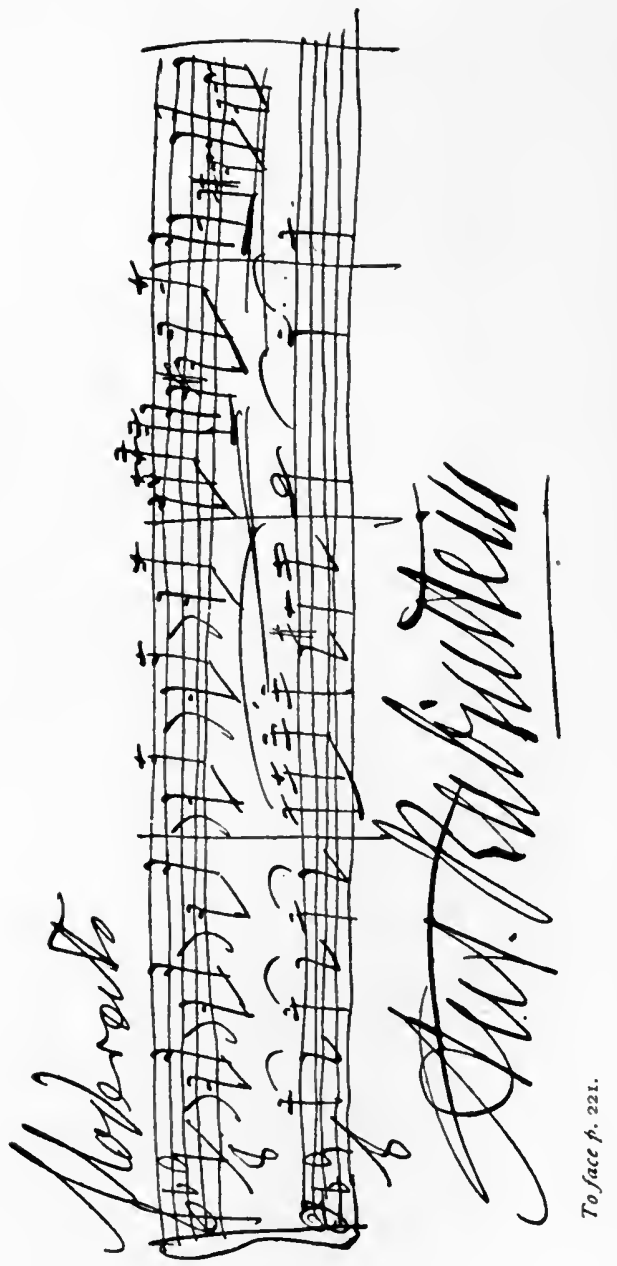


Hibernian enterprise, came out with a special edition, in which was conveyed to the good people of the Irish capital the pleasing, not to say thrilling, intelligence that Mr. Bradlaugh, accompanied by his secretary, had arrived that morning in Dublin. 


\section{CHAPTER XXXII.}

PIANISTS.

Sophie Menter-Her father-The pianist's post at St. Petersburg-Her pupil Sapellnikoff-A feline companion-A mysterious hamper-Pussy in the artist's room-Madame Essipoff-Leschetizky-Paderewski's professor-Hans von Bülow-A splendid conductor-Anecdotes of his witThe circus band insulted-' Court pianist to the German people'-Vladimir de Pachmann-An unrivalled exponent of Chopin.

Having given some account of the great vocalists whose efforts during the last half-century have afforded infinite pleasure to myself, in common with countless other musicians, I must now add a few reminiscences of remarkable pianists, reciters, conductors, entertainers, and theatrical, or, rather, operatic managers.

Now, place aux dames. Of Clara Schumann, Camilla Pleyel, Arabella Goddard, and Fanny Davies, I have already had occasion to speak. Among their compeers I should mention Sophie 
Menter. This illustrious pianist is the daughter of Karl Menter, who was one of the best violoncello-players I ever listened to. $\mathrm{He}$ lived in Munich, and frequently performed with me at the concerts which I gave in that city in $1844-45$. Sophie, who exhibited remarkable talent from her earliest years, was a favourite pupil of Tausig and Liszt. The latter remained her close friend until his death, and was frequently a guest at her beautiful castle in the Tyrol. Her exceptional mastery of the keyboard secured for her marked successes in the principal European countries. She now lives principally in St. Petersburg, where she fills.an important post at the Conservatoire, spending the summer at her Tyrolese castle. One of her most prominent pupils is the young Russian Sapellnikoff, who has been heard and admired in England. It is a somewhat singular fact that the daughter of an eminent violoncellist should have married a still greater performer on that instrument, Herr Popper, the well-known composer.

Apropos of Sophie Menter, I imagine that very few people are aware that she has an extraordinary affection for cats. For aught I know, her taste for dumb creatures may not be confined to this particular class, but I can only speak from 
what I have personally observed. She has-or used to have-as I have said, a remarkable fondness for cats, not the ordinary common or garden tabby species, but great, big, splendid, soft, purring, cuddlesome Persians, of the pampered and petted variety. I trust I shall not be suspected of wishing to throw in any way ridicule on an ainiable and gifted lady when I state that such was her adoration for pussies that she used, when on tour fulfilling concert engagements, to take her favourites about with her.

I remember some years ago her coming down to Brighton to play at a concert I gave. Into the artists' room she brought a large basket, which she proceeded to place, with much care and tenderness, on one of the chairs. There was nothing very singular in this. It might have contained sandwiches of a more dainty quality than lay on the table for such of the artists as might choose to help themselves to a snack. Or it might have contained books, music-what not, in short? But one of the first things the owner did on arriving was to open the panier very carefully, look inside it for a few moments, and then close it with equal care. Thereupon the curiosity of her brother and sister artists was aroused. What on earth could the mysterious 
package conceal? Was it chicken and champagne with which the distinguished pianist meant to fortify herself before making her bow to the audience, or part of her travelling attire, or a hot-water bottle designed to comfort cold feet, or what?

Every conceivable suggestion was made with the view of unravelling the mystery, but somehow or other no one ventured to go to the lady and ask her to solve the problem. It was left to my friend Edward Lloyd, who was among the vocalists, to make the important discovery. He was conversing with Madame Menter-keeping the while an eagle eye on the strange basket by her side-when, of a sudden, there emanated from that quarter a plaintive and prolonged 'meeow.' It was Sophie Menter's cat-a magnificent, bushy-tailed Angora-and the 'mystery of the basket' was solved. It had been brought to Brighton, not for change of air-for that could hardly have been obtained in a closed basket in a stuffy artists' room-but to keep its mistress company.

Curiously enough, Madame Menter had only come down just for the concert, and was returning to London the same night, so that pussy's visit to the seaside was a flying one. The 
discovery of the feline pet created a good deal of amusement among the artists, and I shall never forget the humorous tone in which Edward Lloyd, on making the 'find,' came up and said, 'Bless me, it's only a cat, after all!'

Madame Essipoff, wife and pupil of Leschetizky, and one of the most brilliant pianists who ever touched a clavier, has been frequently the recipient of British plaudits. In St. Petersburg her husband was accounted a teacher of the first rank, living there for some years, and bringing many novices to perfection. His labours are now carried on in Vienna, whither pupils flock to him from all parts of the world, Paderewski being the most prominent example of his preceptorial successes.

Hans von Bülow, a worthy disciple and lifelong friend of his master and father-in-law Liszt, was not merely one of the foremost executants of his day, but a conductor of almost phenomenal ability. A man of varied gifts, he was also profoundly read; and as a writer possessed of a style exceedingly graphic and trenchant. His wit, too, was of the keenest; but, unlike Rossini, he frequently offended his friends by sarcastic speeches publicly uttered. When excited, as he frequently was, he cared not what he said. His witticisms 
are household words in Germany. Few of them, however, will bear translation, while so many of the others refer to well-known and highlyesteemed musicians, that I refrain from repeating them.

At one of his orchestral concerts in Berlin, he prefaced the performance of Meyerbeer's March from Le Prophète with a little speech, in which he told the audience that he would play it in such a manner as to enable them to form a correct estimate of how it should be rendered, for the performance of the piece at the Opera on the previous night was what might have been expected of the band at the Circus Renz.*

The Opera House in Berlin being an Imperial institution, Von Bülow's remark naturally gave great offence, and he was ordered to make a public apology at the next concert. This he did in the following terms: 'Ladies and gentlemen, I have an apology to offer. I mentioned at my last concert that the rendering of the March from Le Prophète at the Opera House was only on a par with the performances of the band at Renz's Circus. I regret the remark, as it might really be considered a libel on the musicians of that excellent equestrian establishment.'

* The most famous circus in Germany. 
An apology (?) of this kind was not likely to have the effect of oil on troubled waters. The Kaiser, in fact, sent to Von Bülow an intimation that he must no longer style himself 'Court pianist to His Majesty the German Emperor.' On receiving the message, Von Bülow expressed astonishment, and asked the envoy: ' $A m$ I Court pianist to $\mathrm{His}$ Majesty the German Emperor ?' 'Why,' replied the adjutant, 'you have it on your visiting card!' Von Bülow, unabashed, looked at his card and said: "To be sure. I had quite forgotten. I will have it altered at once.' And so he did, by substituting the word 'people' for 'Emperor.' His new cards accordingly read thus :

\section{HANS VON BÜLOW,}

Court pianist to his Majesty, the German People.

A composer once called upon the Doctor, and played him his 'last new song.' When he had done so, he observed: 'I think this melody ought to become popular.' Builow, whose ears were quick to discern in the piece reminiscences of other compositions, crushed the young man with the remark: 'Oh, but it is so already.'

The Russian pianist, Vladimir de Pachmann, created, on his first appearance in this country, 
considerable sensation. A great many persons, it is true, derived quite as much enjoyment from watching the extraordinary antics and quaint grimaces in which he indulged while at the keyboard, as they did from the intrinsic beauty of his playing. I have personally, indeed, known of people with no claim to being musical, who have attended concerts at which he performed simply and solely for the purpose of being amused. But let me do Pachmann the credit to which he is assuredly entitled, and add that in the interpretation of Chopin he proved himself unrivalled, and that I have heard him play certain excerpts of the master with more finesse and beauty of expression than any other pianist to whom I have ever listened. 


\title{
CHAPTER XXXIV.
}

\author{
PIANISTS \\ (CONTINUED).
}

The mantle of Rubinstein-Sympathy between artist and audience - Paderewski's conscientiousness - Assiduous practice at night-His facile memory-Never repeats himself-Compositions-Powers apart from musicRecreations - Billiards - Croquet - Superstitions - His walking - stick-Anecdote-Lucky crossing - sweepers-A plain-spoken boy-Saint-Saëns-Qualities, artistic and personal-A perfect organist-His improvisations-Instance of facility-Josef Hofmann-His musical organization-Engaging qualities-Illness in America-Rubinstein as a prophet-Hofmann visits us in Brighton-His talent for drawing-Cassell's pictures-Stavenhagen-A pupil of Liszt-Sauer-Rosenthal-Reisenauer.

THE world of music being now bereft of Rubinstein, it is only natural to speculate as to the musician who has the best claim to wear his mantle. For my part, I am disposed to think that it has fallen upon Paderewski, who, in many of his characteristics, bears a very strong resem- 
blance to the Russian master. $\mathrm{He}$ not only possesses Rubinstein's kindness of heart, benevolence, and generosity, but he seems to have inherited the hold which that lamented artist had upon the public throughout Europe and America. The sympathy between artist and audience in the case of Paderewski, as in that of Rubinstein, is almost magnetic, and the Polish pianist possesses at least as many admirers as his forerunner, while his drawing capacities are quite as potent.

Gifted, as he undoubtedly is, to a most extraordinary degree, Paderewski's sense of responsibility does but increase with his popularity. $\mathrm{He}$ practises indefatigably, choosing for this purpose mostly the hours of the night and a place of solitude-often a room in a pianoforte warehouse, where he remains for hours, playing over exacting passages scores of times. Hence that peculiar grace, that perfection of finish, that gossamer-like touch which makes his notes speak as though the wires were responsive rather to a gentle breeze than to the pressure of a hand.

Paderewski's memory, too, is of the happiest. He has played in London fifteen or sixteen times at the very least; yet, to my knowledge, he has not once repeated himself. And this characteristic of his shows itself outside the domain of his art, 
for he never forgets a face or a name. Of his compositions, it may be said that his contributions to pianoforte music are full of charm and originality. Paderewski knows the secret of imparting attraction to technical difficulties, which are never inserted in his compositions merely for the sake of dry virtuosity; and one is often amazed to find lurking among passages which make considerable demands upon the deftest executant that spirit of simplicity which gives to Paderewski's writings an indefinable cachet.

Paderewski is a most entertaining companion. His knowledge and conversational power on all subjects is not a little remarkable. Rubinstein, as we have seen, had a passion for cards. Paderewski finds his greatest delight in his hours of recreation in billiard playing, while he handles the croquetmallet as accurately as he does the cue. Like Rubinstein, again, he has his little superstitions, and will never sit down one of thirteen to dinner. He possesses a small walking-stick, which he takes with him to all concerts 'for luck.' On one occasion he arrived at St. James's Hall without it, but becoming aware of its absence, he drove in all haste to his rooms, and brought it back with him, for once keeping his audience in expectation and wonderment at this unwonted departure from punctuality. 
I hope the pianist will forgive me if I divulge the curious fact that he never passes a crossingsweeper without bestowing a handsome gratuity upon him-a characteristic which is certainly not lost on the sharp-witted brethren of the broom, who soon get to know of his arrival in London, carefully noting his public engagements, and putting themselves in his way with a confidence which never misses its reward.

On one occasion when he lunched with us, M. Paderewski told an amusing story about his son. When quite a little boy, he asked his father, who was fulfilling engagements in Paris at the time, whether he might go to the Cirque, where he was to perform. The distinguished pianist consented, and the lad was accordingly taken to the concert. When he came home, his father asked him how he had enjoyed himself.

'Oh, not at all,' was the youngster's reply. 'It was the dullest cirque (circus) I have ever been to. I expected to see you go through hoops, but you only played at the piano, just as you do at home.'

From America, where he has been playing to enormous audiences-in one case (at Chicago) representing nearly $\$ \mathrm{I}, 500$ - the distinguished pianist, upon hearing that I was engaged in the 
preparation of this volume, sent me the letter which I give in facsimile.

I must now say something about another composer, a singularly remarkable man-equally so whether we consider him as composer, organist, or pianist. I refer to Camille Saint-Saëns, one of the most distinguished musicians of our time, and the possessor of one of the most unassuming and charming natures I have ever known.

As a composer, Saint-Saëns has been a prolific creator of magnificent works in every branch of music. His operas-particularly Henry VIII., and, more recently, Samson and Delilah-are great favourites in the land of his birth, while his Danse Macabre is one of the most original contributions to the later romantic school. Pianoforte and violin players are indebted to him for several important and attractive additions to their répertoires, to mention only the Pianoforte Concerto in $G$ minor and his Caprice for violin.

The place of Saint-Saëns as a pianist, and perhaps more particularly as an organist, is a high one. In improvising, especially, he is full of originality and resource. I took my family, in the seventies, to Boulogne, where Saint-Saëns and some other musicians from London happened to be staying, and I well remember a little dinner-party to which 
How ches Mrinneur Kuthe,

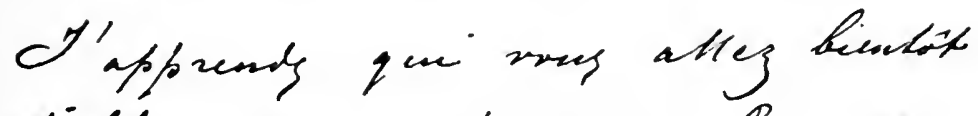
fintlier ons mémingy. $C_{e}$ sesa, J'en uni oxis, un e've'mensent imfortant move seadement froce nong

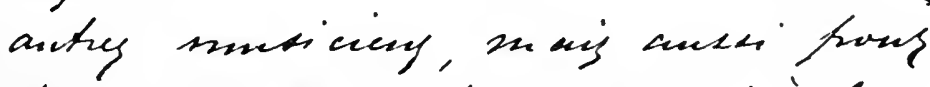

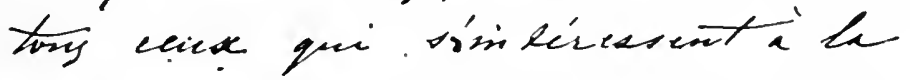
musique. Aynat consue de si josis trat ce un'il zy a ue de grand at - illuotic eny natue cher ast; ayant prij, meus-mime, ine past 4 active dang \& déricloppement musical de phuriensy bays, ravy me dembleg prosidies tuaty ly quatity necersing

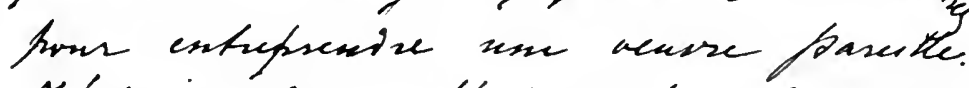
I'ittengy sive l'appasition he suthe merage ane infiationic at, ex my 


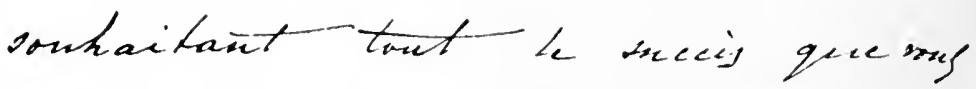

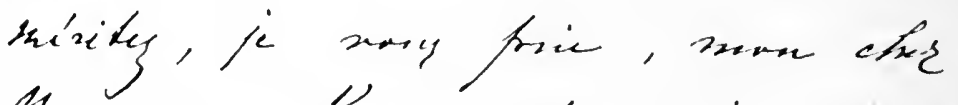

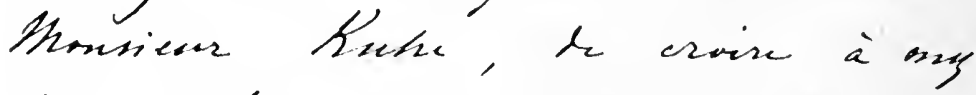
tiois - affecticene dentimenty

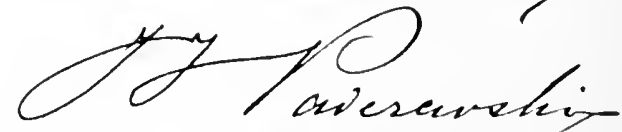

adescurtei

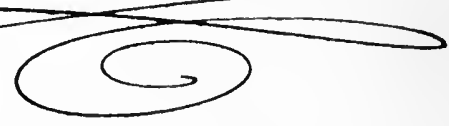

San- Exncise

le 12 Pemies

$$
1896
$$

To face p. 234 . 
he invited the late Dr. Hueffer, Mr. Isidore de Lara, Mr. Wilhelm Ganz, and myself. When, later in the evening, he sat down to the piano and delighted us with an extemporization in the style of Handel, it was easy to imagine that we were listening to one of the finest compositions of that immortal genius, instead of an impromptu imitation. But I have said enough faintly to indicate the remarkable gifts of this renowned artist.

By way of contrast, let me now notice one who hardly yet enjoys the fulness of fame which undoubtedly awaits him in the future. In the course of the musical season of I 887 a little Polish boy came to England, and raised storms of applause-and controversy-wheresoever he went. Josef Hofmann, the prodigy of nine years old, for a long time twisted us all round his little fingers. What astounded professors even more than his facility at the pianoforte-truly magical as it was in one of his tender years - was the extraordinarily musical temperament of the boy. At the same time, the child was so simple, natural, boyish, and engaging, that he enraptured audiences and endeared himself to everyone who knew him in private. His nerves, however, strung to the highest tension, gave way under the torrent of excitement evoked by his 
arrival in America, whither he went from England. The youngster completely broke down at one of his recitals, and I heard from eye-witnesses of the touching scene which took place when, in the middle of the performance, he began to weep bitterly, exclaiming: 'But I am only a little boy !'

His parents very wisely withdrew him at once from the public gaze, and complete rest and care gradually restored him to health.

Rubinstein, on hearing him play, without hesitation undertook his musical training, prophesying a great career for his gifted pupil. Josef Hofmann has already begun to justify his master's prediction, for his success as a matured artist at the age of seventeen has been such, both in Germany and in England, as to leave no doubt that he is a pianist of the first calibre.

Apropos of Josef Hofmann, he stayed with my family in Brighton when he first visited England, and we were all immensely struck by the little man's intelligence, the keen interest he displayed in things apart from music, and, above all, by the precocious talent he manifested for drawing. In fact, his 'drawing ' powers were, in more senses than one, surprising. He confided to my daughter that he would like to be a draughts- 
man, and, from the specimens he gave us of his capacity in that direction, I may say that young Hofmann would probably have made a name with his pencil.

Personally, I have so little sympathy with the practice that has obtained in recent years of bringing to public notice the wonderful gifts of juvenile performers, that I do not in the least mind recounting a little incident which clearly shows that here was one, at any rate, of the number who derived sensations other than pleasurable from appearing in public. The little fellow was, on one occasion of his visit to us, deeply engrossed in a volume of Cassell's Illustrated History of England, in the pictures of which he betrayed the utmost interest. But the time came when duty called him to another room, where he was to rehearse the pieces, in the interpretation of which he was anon to delight an astonished audience. My daughter asked him, more in fun than in earnest, which he would prefer-to spend the afternoon in contemplation of Cassell's pictures, or with his fingers on the keyboard. This was his reply, couched in a minor tone :

'Ach, sehen sie, ich spiele so viel!' (Ah, you see, I play so much.) 
What could have been more eloquent or more pathetic ?*

I might speak of many other pianists, but as their name is now legion, I must necessarily restrict myself to the briefest possible mention of only one or two of the most prominent.

Stavenhagen, a young Scandinavian and favourite pupil of Liszt's, accompanied his master on the occasion of his last visit to London, and was by him introduced to the British public.

During the season of 1895 three other aspirants to public favour have paid us prolonged visitsEmil Sauer, Moritz Rosenthal, and Alfred Reisenauer-for all of whom lasting success can safely be foretold. The first-named immediately made his mark in classical music both old and modern. Rosenthal's powers of execution are phenomenal, although I believe some hold that he has yet to be judged as an interpreter of classical works. That the result will be perfectly satisfactory I do not for a moment doubt. As for Reisenauer, he has won for himself a host of admirers.

* Another young pianist who has survived the ill-effects of a premature introduction to the public is Max Hambourg. He will undoubtedly be a lasting celebrity. 


\section{CHAPTER XXXV.}

SOME VIOLINISTS OF CELEBRITY.

Prume-La Melancolia-A one-horse composer-Violinists in London, I845-' The mighty Vieuxtemps'-Admiration for Spohr--Jessonda and The Power of Sound-A Norwegian fiddler-Ole Bull in Germany-Player and philanthropist-Mr. Henry Jarrett-Carl Formes-New reading of the Kreutzer Sonata-I hear Ernst in I 839His subsequent visit to England-The violinist befriended by Lord Lytton - Paganini's pupil, Sivori - 'No impostor' -A non-classical executant-His economic propensitiesToo late for the train-Walking a luxury-molique at Stuttgart-His pupil, J. T. Carrodus-Prosper Sainton and his gifted wife-Mendelssohn impressed-Royal Academy of Music-The principal's choice of a successor-Emil Sauret.

In my time I have known and heard, I may say, all the violinists of distinction from the period when I was taken to the Paganini concert (previously referred to) down to the present, and I now propose to write of some of them.

Among my early experiences I recall Prume, who gave many concerts in Germany, and also composed a good deal. One of his pieces, $L a$ Melancolia, was an immense favourite, and 
whenever he played this air and variations, the room was crowded. The opening bars were :

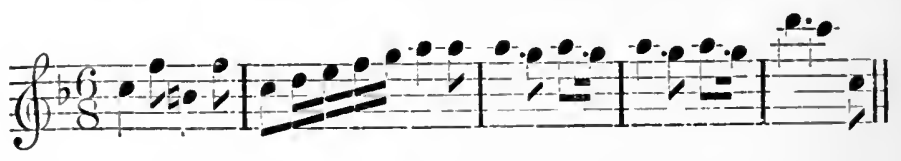

Prume was not a classical player, nor by any stretch of courtesy could he be called a great virtuoso, but he was only one of many artists I shall have occasion to mention who achieved a reputation on the strength of a single work. Curiously enough, he came to London in 1845 (my first season in the English capital), but the mighty Vieuxtemps, who was here at the same time, completely overshadowed him. In every direction he was sought after, while poor Prume hardly had an opportunity of being heard.

In the same year, Spohr was in London. I had an enormous admiration alike for his playing and his works ever since I can remember. In particular, his opera Jessonda, and his symphony, The Power of Sound, exercised over me an extraordinary fascination. At the time of which I am speaking, Spohr was no longer in the prime of life; but his tone was still wonderful, and his execution exceedingly fine. Of the present-day violinists, Dr. Joachim reminds me more of Spohr than any other I have heard since his time. 
I will here mention other names as they occur to me. The Norwegian artist Ole Bull created an enormous sensation everywhere. $\mathrm{He}$ built up an immense fortune, was a great philanthropist (differing in this respect from Paganini), and spent his earnings in founding a colony in America for his poor compatriots, to whom he allotted land. He ultimately, I believe, settled in the colony. Some years ago Mr. Henry Jarrett persuaded Ole Bull to return to Europe for a short while and join Carl Formes, the German basso (then quite passe), in a concert tour. The party came to Brighton, and were associated in a concert under my auspices. On this occasion I played with Ole Bull the Kreutzer Sonata. The violinist gave such an extraordinary and novel reading of the familiar work that any musician might have been excused who failed to recognize it.

I should here allude to Ernst. I first heard him in Prague in 1839 . His playing struck me as being singularly poetical, but he often performed under great disadvantages, by reason of his indifferent health. Often when ill he would attempt overpowering difficulties, and consequently fail. When, in later years, Ernst visited England, we became intimate friends. In I 849ten years after my first introduction to him--he 
organized a tour of the leading provincial cities, and engaged me as pianist. With Ernst, too, I used to play the Krentzer Sonata, but his was a very different version to that given by Ole Bull. Sims Reeves, and the lady who afterwards became his wife (Miss Emma Lucombe), were of that party.

In after-years I saw Ernst in Germany. Poor fellow! he was then in the worst stage of paralysis, and had to be carried about. He died universally beloved and respected. But before concluding my recollections of this great and highly-esteemed artist, I should like to mention an anecdote, showing in what warm regard he was held by his friend Lord Lytton. The famous novelist became acquainted with Ernst in Italy. The artist, then in failing health, was anxious to leave that country, but was too proud to confess his inability to defray the expenses of a long journey. Lord Lytton knew of Ernst s poverty, but did not wish to wound his sensitive feelings, so he begged him 'as a favour' to accompany him to Paris and England as his guest, on the ground that he detested travelling with strangers, and consequently always secured a carriage for himself. This. kindly offer enabled the great virtuoso to make the journey free of cost. 
In this brief record of violinists I have known, I must not forget Sivori, whom I heard in my native city in $1840 . *$ He did honour to his illustrious predecessor Paganini, whose pupil he really was. I mention this because so many violinists of this period proclaimed themselves as pupils of the greatest of all fiddlers, just as in later years so many pianists claimed to have studied under Liszt. But Sivori was no impostor in this connection, and he was, indeed, one of his master's most favourite pupils. When I heard him I was greatly impressed by his wonderful technique, the richness of his tone, and, above all, by his 'fire' and indescribable entrain.

Sivori was good enough to evince some little interest in me, and took me on a concert tour, visiting Carlsbad, Marienbad, Franzensbad, and other Bohemian health resorts. Some years later (I think in 1848 ) he came with Piatti, then quite a young man, to Brighton, to play with me at one of the first concerts I gave in that town. Sivori never professed a fervent love for classical music, nor did he play very much in that school. I once, though, heard him perform Mendelssohn's Concerto. The execution was perfect, but it gave

* It was early in the forties that two young girls, Teresa and Maria Milanollo, created in Germany an immense sensation. 
me the impression as of one who moves in some strange palace, unaccustomed to aught but his own homely surroundings.

Whether it was through contact with his illustrious master I know not; but certain it is that Sivori was imbued with a strong sense of economy. My friend, the late Willert Beale, once told me a good story in illustration of this trait in the artist's character. Mr. Beale had engaged Sivori for one of his touring-parties. When at some town in Ireland, the accomplished violinist could not be induced to share a fly with some of the other artists to the station. No, he said, he would rather walk, notwithstanding that time was short. The result was that, in order to catch the train, he had to run the whole way. Reaching the terminus in a state of utter exhaustion, he found to his unmitigated disgust that his train had a minute or so previously steamed out, and it then became incumbent upon him, in order to avoid a breach of contract, to engage a 'special' to convey him to the town at which he was to play the same evening. So for once the prudent man had inadvertently broken loose from the fetters of rigid economy.

In 1845 , at Stuttgart, I made the acquaintance of Molique, in whose hospitable house I soon became a persona grata. The then famous violinist was 
also a composer of considerable distinction, and an all-round musician. Curiously enough, although he wrote in nearly every branch of music, his works, fine as they were, are seldom heard at the present day. A few years after I first knew him, Molique came and settled in England, where he had innumerable friends, admirers, and pupils, among the latter my old friend, now no more, Mr. J. T. Carrodus, a special favourite of his master's.

Another violinist with whom I have had pleasant association was Prosper Sainton-an excellent performer and a first-rate teacher. I was fortunate, too, in numbering amongst my friends his charming and gifted wife, Charlotte Dolby, in her time England's greatest contralto. It is interesting to recall that, when quite young, she very favourably impressed Mendelssohn, who heard her sing in Leipzig, and expressed the utmost admiration for her talent. To revert to her husband, he was exceedingly popular at the Royal Academy of Music, from which he produced a number of very capable pupils. On his death, a bold but wise step was taken by Sir Alexander Mackenzie, who persuaded Monsieur Emil Sauret, one of the first violinists of the day, to come to England and assume the position left vacant at the national institution over which he presides. 


\section{CHAPTER XXXVI.}

\section{ARTHUR SULLIVAN.}

An appreciation - The gaiety of the nation-The Mikado in Germany - How it impressed my young friend.

To praise the most versatile and prolific musician England has ever known would be an act of utter supererogation. One of these days the task will devolve upon some historian (who will have to wield an eloquent pen indeed) of giving to the world faithfully and appreciatively the life and brilliant career of Arthur Seymour Sullivan. That task is not for me.

To seek to underrate his transcendent gifts could only be the act of one inspired by jealousy of a talent so prodigious. But Arthur Sullivan has no enemies. I, for one, have never heard a word uttered in depreciation of his musical genius or in condemnation of his private life. And I shall but echo the sentiments of every man and 
woman with whom he has ever been brought into personal contact, when I affirm that a kinder and less selfish fellow never lived than Sir Arthur Sullivan. A disposition more genial I, personally, have never found in any man; while in the ranks of musicians no one, probably, is more ready to appreciate and extol the talent and overlook the failings of brother professionals than he. In these circumstances, I ask, who could be found, even in a world of petty jealousies and animus and strife, to speak disparagingly of the composer who gave to this country, in the Golden Legend, a work that will live for all ages; in Ivanhoe, an opera every page of which bears the imprint of his genius; and (with William Schwenk Gilbert) in the unbroken series of Savoy successes, masterpieces-I use the word advisedly - in the way of light lyrical composition, which have done more to increase the gaiety of this nation than any artistic creations that I can call to mind? The art of writing the most lilting and exhilarating of music in such a fashion as to delight the uninitiated and the scholarly alike was invented by Arthur Sullivan. He has found many imitators, but no compeers. He can never be surpassed.

The following little story may perhaps interest his many admirers. A few years ago I was 
staying with some friends in a small German country town. The son of my host had come of age, and, by way of giving him a treat., his father furnished him with the wherewithal to spend a week in Berlin and see the sights of that interesting city. He was to go to the opera, 'do' the theatres, and, in short, amuse himself to his heart's content.

In the way of entertainments, I need hardly say, there is enough and to spare in the German capital, and naturally, on the return of the young wanderer, his parents were anxious to learn in what manner he had enjoyed himself. What did he think of the Opera House? What were his impressions of the singers? Which plays did he prefer at the theatres? and so forth.

'Well,' he replied, 'I have had a very good time. I went to see the Mikado.' (It was then the rage in Berlin.)

'Oh!' remarked the lad's father; 'and what besides?'

'Nothing else,' was the reply.

Somewhat astonished, my friend asked the boy what he did on the remaining five evenings in the week. Then came the explanation. On the night of his arrival he was taken by a friend to see the Gilbert-Sullivan opera. Nothing had 
ever given him so much pleasure, and he could not resist the temptation of seeing the piece again on the following evening. This second visit only served to increase his appetite, and judge of his father's surprise on learning that he went a third, a fourth, a fifth, and a sixth time to see that inimitable and fascinating work. There were plays and operas to witness galore, but he could not tear himself away from the theatre to which the Japanese opera was attracting all Berlin.

But my friend had never seen the Mikado, and was at a loss to understand the seemingly extraordinary fascination it had exercised on his son. Of the latter's immeasurable capacity for enjoying the same piece night after night he had, truth to tell, some little doubt. On this score, however, he said nothing to me ; but a few weeks later, happening to find himself in Frankfort in my company, what time the great Savoy success was being played there, he not unnaturally expressed a desire to see the piece. Quite willingly I accompanied him. Well, my friend's delight and enthusiasm as the various droll situations succeeded one another, and the graceful and enchanting strains fell upon his ears, was wonderful to behold; and when, at curtainfall he confided to me that until that moment he had hardly credited his son's Berlin experience, 
but that now he believed every word of the account he had given of his week's sojourn, I confess that I was immensely amused.

'Did you believe him?' he asked me subsequently.

' Of course I did,' was my answer.

I had seen the Mikado in London. 


\section{CHAPTER XXXVII.}

COMPOSERS AND ORCHESTRAL CONDUCTORS.

The importunate interviewer-'Story, sir, I have none to tell 'Fantastic farrago-Julius Benedict at the desk-Mendelssohn at the Philharmonic concerts in I 847 - The Hymn of Praise-Michael Costa and some of his successorsBalfe-Sterndale Bennett-William Cusins-Master of the Queen's Music-F. H. Cowen-As a boy composer - Bright promise fulfilled-The Scandinavian Symphony - A composer with lofty aims-Cowen in the Antipodes - Sir Alexander Mackenzie-Richard Wagner and the Philharmonic concerts-Sir A. Sullivan as conductorEdvard Grieg-A meeting with Dvoràk-The Spectre's Bride.

Some years ago an interviewer-one of those wonderful creatures who make you say in print all sorts of strange things which, to put it mildly, you never intended to convey-called upon me, and, in course of conversation (the interviewer, by the way, did all the talking), asked me whether I had any 'good stories' to tell concerning conductors. I assured him that I hadn't. 
'Not one?' he asked, almost pathetically ; for I had furnished him with very little ' copy.'

'No,' I replied; 'I can't think of anything to tell you on that score.'

But the journalist, after his kind, was not to be done, and in the paper-it was a magazine, the name of which I forget-in which the interview subsequently appeared, I was credited with the statement that Sir Michael Costa was once present at a performance I conducted of Eli, and that when it was over the illustrious composer came round to the artists' room, and, grasping me by the hand, exclaimed:

' Never have I seen a conductor hold his orchestra under such masterly control! The performance under your bâton has opened my eyes to the fact that I have written a great work.'

And, if I recollect aright, the perpetrator of this fantastic and ingenious story added, by way of being daringly original, that $\mathrm{Mr}$. Kuhe was delighted at receiving 'praise from Sir Hubert.' Probably I should have been ; and this final touch, therefore, constituted the only true statement in the amazing narrative.

I recall the incident because I propose to devote a few lines to the subject of the chefs d'orchestre I have known ; but I must warn my readers that I 
cannot entertain them with any anecdotes relative to these conductors. In fact, what I said to the imaginative scribe holds good now-stories concerning them I have none to tell.

Sir Julius Benedict was far from being an ideal orchestral conductor. His beat was too uncertain, with the result that the players sometimes had the greatest difficulty in following him. As an accompanist, however, he has probably never been surpassed.

In one of the foregoing chapters I have alluded to a concert of the Philharmonic Society at which I was present in I 847 , and which was conducted by Mendelssohn. That was the only occasion upon which I ever saw the composer of the Hymn of Praise at the conductor's desk, and I was immensely impressed by his mastery of the art. At conducting, as in everything else, the great man excelled. The occasion in question was the only one, I believe, upon which Mendelssohn performed a like office for the Philharmonic Society, whose concerts at that time were conducted by Sir Michael Costa, who had succeeded Moscheles. Costa, by the way, had up to then been associated with Her Majesty's Theatre. where his place, on leaving, was filled by Michael Balfe, the popular composer. Fortunately for the 
management - to say nothing of the audiencethe old operas then in vogue did not require such able conductors as more modern works, and Balfe answered Mr. Lumley's purpose well enough ; but even his warmest admirers could hardly have considered him a leader of exceptional merit.

The Philharmonic Concerts had several conductors within my recollection. Sterndale Bennett, in his time Principal of the Royal Academy of Music, held the post for a number of years with credit to himself and the forces under his command. English musicians were rightly proud of this composer and conductor. Most versatile was his talent, for not only may he be said to have been a truly classical writer, but he was a most gifted pianist, while as a teacher he enjoyed a deservedly high reputation. Many of his compositions will surely live. I need only recall a few-those beautiful cantatas, the May Qucen and the Woman of Samaria, his overtures Naiades and the Wood Nymphs, and his Pianoforte Concerto in F. His works always reminded me (not in the sense that he was in any way a plagiarist) of those of Mendelssohn, whose intimate friend and fervent admirer he was.*

* Sterndale Bennett received the honour of knighthood in 1871 , at the same time as Sir Julius Benedict and Sir George Elvey. 
Sir (then Mr.) William Cusins succeeded Sterndale Bennett as conductor of the Philharmonic Concerts. As chef d'orchestre he had considerable experience, and he was for many years Master of the Queen's Music, besides being the conductor of all the Sarasate and other concerts. Sir William's premature death was deplored by all musicians.

One of the most popular and able of the Philharmonic conductors was F. H. Cowen, concerning whom it would be easy to write a long biographical notice. This, however, I do not purpose doing. Suffice it that the musical historian of the future (by which I do not mean the chronicler of the 'music of the future ') will find it an agreeable task to make note of the fact that as a small boy Cowen astonished his friends with compositions written in classical form; and that the bright promise held forth in those early years has more than borne fruit. It must be left to such a biographer to record the many different spheres of art in which the varied attainments of this facile composer have asserted themselves.

To enumerate even a tithe of the oratorios and other sacred works, operas, symphonies, and drawing-room pieces with which Frederic Cowen has enriched the world would be a formidable task indeed. No reference to the distinguished com- 
poser, no matter how brief, should, however, omit mention of that beautiful, descriptive, richlycoloured, and pre-eminently scholarly work, the Scandinavian Symphony, a composition which, not only in this country, but in every part of the Continent, is rightly regarded as a chef d'cuove. Above all will Cowen's name be handed down to future generations as that of a composer who has never pandered to the 'Philistines' in music, or written 'down' to the level of those whose appreciation of the divine art is limited by their meagre knowledge of its beauties. And finally will it have to be recorded that one of his achievements has been the spreading of a taste for high-class music in Australia, where he conducted a series of orchestral concerts-a task which no one, assuredly, was better able to perform.

No need is there to speak of the present conductor of the Philharmonic concerts. In that capacity no musician will gainsay that Sir Alexander Mackenzie is 'the right man in the right place,' while as a composer he is almost as well known and as much esteemed in Germany as he is in this country.

By the way, in speaking of Costa, I should have mentioned that when he retired from the conductorship of the Philharmonic Concerts, the 
directors of the Society invited Richard Wagner to come over to this country and take his place. He did so, but for one season only. His readings of familiar classical works, as many amateurs doubtless remember, were totally different from those to which they were accustomed. At that time his own works had not even begun to be understood, and there existed, moreover, some feeling of jealousy that a foreigner should have been selected for the important post of conductor of those concerts. At any rate, the engagement was not a success, and was not renewed.

I omitted to record that in the season of 1887 the Philharmonic Concerts enjoyed the immense advantage of the presence at the conductor's desk of Arthur Sullivan. With the addition of his name to the foregoing, it will be observed that the Philharmonic Society's 'roll of honour' is a very distinguished one.

Let me not conclude this chapter without some brief mention of two names illustrious among the composers of the present day-Edvard Grieg and Anton Dvoràk, both of whom, by the way, have been, as all amateurs are aware, identified with the Philharmonic. The acquaintance of the latter I made at Birmingham, on the occasion of the production of his magnificent work the Spectre's Bride. 
Being a compatriot of his, I then addressed him in the Bohemian tongue, a language of which I had made no use for over forty years. It happened, therefore, that in speaking to my countryman I was guilty of a slight grammatical error-a slip which the composer was quick to detect and rectify. It may interest his many admirers to learn that this gifted writer, who can now command any sum for composing or conducting, was at one time organist at a church in my native city of Prague, in which capacity he received emoluments amounting to $£$ I 2 a year. 


\section{CHAPTER XXXVIII. \\ OTHER ENGLISH COMPOSERS.}

Arthur Goring Thomas-A favourite song of Lloyd's-C. H. Hubert Parry - The 'English Bach '-C. Villiers Stanford -J. F. Bridge-His Purcell researches-A. C. Mackenzie -A Liszt 'subject'-F. H. Corder-Translations of Wagner--Edward German-English music in the Fatherland.

I HAVE touched elsewhere upon the gifts of Arthur Sullivan and Frederic Cowen, and it only remains for me now to advert briefly to the part played by one or two other notable Englishmen in the development of their art in this country.

Of that facile, refined, and musicianly writer, Arthur Goring Thomas, whose lamented death in the prime of life robbed amateurs of a richlyendowed melodist, I will simply recall the fact that his charming opera, Esmeralda, both on its production in English by the Carl Rosa Company, and subsequently in Italian by Sir Augustus Harris at Covent Garden, with Madame Melba 
and Jean de Reszke in the cast, won a success fully commensurate to its merits. To this day the song, Oh Vision Entrancing, from that opera, is one of the most favourite in Edward Lloyd's répertoire.

Of Hubert Parry it may with truth be said that he is one of the most learned musicians England has ever known, and he is held in the highest esteem by the whole body of amateurs. Dr. Parry has frequently been styled the 'English Bach,' but his writings always remind me, by reason of their vigour, power, and manliness, more of Handel. No musical festival is now considered complete which does not bring forward a work from his scholarly and brilliant pen.

Another writer whose name should be linked with the foremost of our modern composers is Dr. Villiers Stanford. No department of composition is there in which the gifted and rightly distinguished professor has not furnished proofs of his legitimate claim to the high position which he holds in the ranks of English musicians. Alike in operatic, choral, and chamber music has he done much to advance the cause of the art in this country.

A word for that enthusiastic musician, genial friend, and witty soul, Dr. J. F. Bridge, dubbed 
by some of his facetious admirers 'Westminster Bridge,' by reason of his long and honourable connection with the Abbey. Not only as organist and composer, but as Gresham Professor, in which capacity he has delivered countless lectures, on which his immense musical erudition has been brought to bear with interesting results, has he established for himself an enviable reputation. Dr. Bridge's researches into the life of Henry Purcell, by the way, were of enormous value to the commemoration of that composer's bicentenary, and greatly enhanced the interest attaching to that celebration.

In the ranks of English composers who have striven always with a high aim in view, and to whom the discriminating applause of the educated minority brings more reward than the untutored enthusiasm of the multitude, a prominent place should be assigned to F. H. Corder. A more sound and scholarly musician it would be difficult to point to. But he has done more than show himself a master of orchestral effects, and a staunch upholder of purity, restraint, and dignity, in the writing of ambitious scores. $\mathrm{He}$ has proved himself to be possessed of a strong and ever-present vein of originality, and it is this individuality and freshness of thought and feeling 
which as much, perhaps, as the intrinsic beauty of his orchestral writing, has earned him the esteem and admiration of all earnest amateurs. Mr. Corder, too, stands entitled to immense creclit for his able and poetical translation of Wagner's operas. They appear in all the books of the master's works, and even in German theatres the English versions that are distributed bear the name of this pre-eminently learned and art-loving musician.

Elsewhere I have made reference to a composer who, although his name is already pleasantly associated with some of the most charming and dainty music of modern times, will, in my opinion, attain to even greater things in the future. I allude to Edward German. But few writers of his years have found so warm a corner in the hearts of amateurs as the young composer, who, espying his opportunity in the commission given him by the Lyceum manager to furnish the incidental music to Henry VIII., put his shoulder to the wheel, and produced a score so graceful, characteristic, refined, and musicianly, that its popularity led to some of its numbers being played far and wide in orchestral and piano form.

Edward German's talent is recognized not only 
in the country which gave him birth, but in music-loving Germany. On my last visit to the Fatherland, go where I would I heard the tuneful and piquant dances which he wrote for $\mathrm{Mr}$. Irving. And it mattered not whether it was in Frankfort, in Wiesbaden, or in Homburg, they at once caught the fancy of all those upon whose ears fell their elegant strains.

In every work, moreover, that he has since written of a more ambitious nature has this composer justified the hopes formed of him.

Of Sir Alexander Mackenzie I have already spoken. Further mention of his name and of his conspicuous services to English musical art must, however, be made in a list which includes the honoured names recorded above; for the Rose of Sharon, only to speak of one of his works, will live so long as music remains a power and a bright influence for good in this land.*

* I believe it is not generally known that one of the last, if not the last, subjects selected by Liszt for elaboration and treatment as a piano piece was a melody in one of Sir A. Mackenzie's operas-I believe the Troubadours. The Abbé had begun to write the piece, and fragments of it were found amongst his papers after his death. 


\section{CHAPTER XXXIX.}

AUGUST MANNS.

Music at the Crystal Palace-A peep into the past-Opportunities formerly enjoyed by amateurs-What the Palace conductor did for them-Few orchestral concerts in London-Pilgrims to Sydenham-The musicians' Mecca -Old masters and young men-The Sydenham institution as a stepping-stone-Mr. Manns and rising artists-Scotch music-Learmont Drysdale-Mr. Manns and the Scottish Orchestra - The conductor's seventieth birthday - A notable gathering-Honours refused-Another pillar of the Palace-Sir George Grove-A friend in need-Two musicians in Vienna-Interesting researches-Musical treasure-trove-The Dictionary of Music.

No one, I hope, will accuse me of a mild form of vandalism if I proclaim a deep-rooted conviction that the fame of the wonderful glass-house on Sydenham's heights is due as much almost to August Manns as to the renowned Sir Joseph Paxton himself. I can never resist the impression that its 'undying attractions,' of which one reads so much, all revolve, so to speak, around the magic 
name of Manns, and that they would stand a very fair chance of extinction if aught happened to deprive the Palace of his presence.

Despite its multifarious attractions and the picturesque beauty of its surroundings, I hold that the Crystal Palace would never have attained its present world-wide repute had it not been for the magnificent work which has been done there by August Manns. And apart from his share in the advancement of the interests of the institution, his services to the cause of music generally in England are such as could not be estimated save by those who have closely watched the progress of the art in this country during the last half-century.

Since Mr. Manns first undertook the musical arrangements at the resort with which he is so closely and honourably identified, many things have happened. Among others, the hackneyed reproach that the English are not a musical nation has come to be regarded as an insult and a libel. But in this connection it may not be uninteresting to take a peep into the past and see what opportunities lovers of music enjoyed of gratifying their tastes at the period when the Crystal Palace conductor came upon the scene. Unless I am greatly mistaken, orchestral concerts in London were few and far between. The concerts of the Philhar- 
monic Society were limited in number, and, moreover, they did not afford opportunities to audiences to become acquainted with modern works, their tendency being so conservative that the programmes put forward by the directors hardly ever contained any but strictly standard works.

When Mr. Manns took over the direction of musical affairs at Sydenham and became the conductor of a permanent orchestra, he not only gave concerts diily, but organized weekly performances on Saturdays, for which his forces were strengthened by some of the best orchestral players from London. Moreover, for these Saturday programmes the best instrumental soloists and rocalists were engaged, and the room being very spacious, the prices of admission-unlike those at the Philharmonic Concerts-were so low as to enable all lovers of music to attend, with the gratifying result that, as the high quality of these performances became recognized, the audiences increased in numbers, and soon the pleasing sight was witnessed of a pilgrimage of amateurs from London to Sydenham to hear that which could not be heard in the Metropolis itself. In a word, the enthusiastic conductor of suburban concerts raised his wand and a public which was supposed to care nothing for orchestral music flocked to a 
place difficult of access to show their appreciation of that for which they were believed to have no liking, and, having come once, returned again and again.

Now, here was the conductor's opportunity to do something for English music and for native musical talent. Audiences with severe tastes knew the old masters by heart, and could play them backwards. None the less were they delighted at all times to renew acquaintance with them, particularly when interpreted by such an orchestra as Mr. Manns had at his command. 'But why not,' argued the director, 'give the young composers a chance? There must be plenty of clever and promising young men of whom the public knows absolutely nothing, and who need only be heard to become known and popular.' And he was as good as his word. So it happened, as time went on, that from the Crystal Palace the fame of well-nigh all the English composers who have since attained to distinction spread, and works of rare promise, and in many cases of rich achievement, were produced amid conditions which revealed all their highest qualities, and gave delight to those who listened to them.

To have a work performed at one of those 
famous concerts, or to have played or sung thereat, was a passport to composers and artists in other important directions. But while opportunities were thus frequent of hearing excerpts of the modern school, as represented by Wagner, Raff, and Brahms, and entirely new compositions by English writers, the claims of the old school were not forgotten, and interpreted as these were with rare finish, they became more and more understood and better appreciated.

For one of my Brighton festival concerts, in I 879 , my old friend, Mr. W. Shakespeare, wrote a concerto for pianoforte and orchestra. My daughter played the solo part and Mr. Manns was the conductor. He expressed himself very pleased with my daughter's performance, and a few months later he engaged her to play the same concerto at one of the Crystal Palace Saturday concerts.

But this is only one of many instances in which he has proved himself kind to beginners, and in the same way, as I have said before, he has lent a helping hand to many young composers. Thoroughly eclectic in the distribution of his favours, it matters not to him what is the nationality of those whom he befriends in this manner. I well remember a 'good turn ' he rendered some 
years ago to a young Scotch friend of mine, Mr. Learmont Drysdale. That talented composer, then a student at the Royal Academy of Music, had written an overture called Tam O'Shanter. He took it to Mr. Manns, who went through it very carefully, and having done so, promised to produce it whenever he had an opportunity. True to his word, he did so not long afterwards, and it so happened that the piece was most enthusiastically received and flatteringly reviewed. I only mention this as a solitary instance where $\mathrm{Mr}$. Manns' readiness to help forward young composers has been a stepping-stone to their advancement.

By way of emphasizing Mr. Manns' extraordinary discernment and his reacy desire to extend a helping hand to young and untried musicians, I cannot do better than enumerate a few composers, unknown at the time he produced works of theirs, whose advancement dates from the day their names first appeared in the Crystal Palace programmes. First and foremost in this list I should mention Sir Arthur Sullivan, of whose works the following, among others, saw the light in manuscript under the conductorship of August Manns : No. I Symphony in C (1866); Sapphire Necklace, overture (1866); In Memoriam, overture (1867); Marmion, overture (I867); and the 
Tempest, produced as far back as in I862. Likewise to Frederic Cowen did the Crystal Palace platform furnish a stepping-stone to richly-merited fame, his symphonies in $\mathrm{C}$ minor and $\mathrm{F}$, and his overtures and entractes to Schiller's Maid of Orleans, being produced there in 1870 and i $87 \mathrm{I}$ respectively. Turning to other composers now holding high positions who first obtained recognition and encouragement at Sydenham, there are C. H. H. Parry, Sir Alexander Mackenzie, and C. Villiers Stanford, all of whom, I believe, had works presented there in 1879 ; Walter Macfarren (pastoral overture, 1878 ), Hamish MacCunn, Frederick Corder, and Edward German, from whose pen a symphony was produced two years before his charming and graceful incidental music to Henry $V I I I$. was heard at the Lyceum. It would be impossible, in a work which is far from claiming to be a dictionary of music, to give anything like a complete list, but to the names already enumerated should assuredly be added those of Sir William Cusins, J. F. Barnett, F. Cliffe, Henry Holmes, F. Lamond, Henry Leslie, Ebenezer Prout, W. Wallace, Henry Gadsby, Thomas Wingham, and R. H. Walthew.

I need not here recall the history of the Handel Festivals at the Palace, which is matter of com- 
mon knowledge. Many tempting offers have fallen to August Manns, but he refused them all, until the directors of the Scottish Orchestra succeeded in placing the control of that famous body of instrumentalists in his hands. An arrangement with the Crystal Palace authorities. enabled him to do this without severing his connection with their institution, and for a considerable period he divided his time between Scotland and Sydenham.

It is interesting to note that, whereas up to this time the Scottish concerts had been carried on at a loss, they so gained in popularity under his sway that a large deficit which had to be faced when he assumed the conductorship was ultimately converted into a surplus, and when he relinquished the post matters were in a very flourishing condition. I believe that after his resignation the concerts again resulted in a loss.

The completion of Mr. Manns' seventieth year, in March, I 895, is an event still fresh in the memory of musicians and music-lovers, seeing that it was made the occasion of proving the high esteem in which he is held by them. It was my pleasure to be present at the reception then given in his honour at the Grafton Galleries, when one of the most distinguished and notable gatherings ever brought together assembled to congratulate the 
veteran maestro, who was also the recipient of a well-earned mark of honour bestowed by H.R.H. the Duke of Saxe-Coburg-Gotha. Wonder has often been expressed that a knighthood has not long since been conferred upon this remarkable man. As a matter of fact, such a token of royal favour has more than once been offered him, but with characteristic modesty he, on each occasion, refused it. If I have not said so already, let me do so now: August Manns, best of friends and most brilliant of conductors, is one of the most modest and unassuming men I have ever met in any profession. And thus I will close this inadequate tribute to his splendid services to musical art in this country.

In justice to one who has rendered incalculable benefit to niusic, I cannot conclude this chapter without making mention of the immense assistance in the development of the movement carried out by August Manns which was given by Sir George Grove. As one of the directors of the Crystal Palace, Sir George lent a willing and earnest ear to the proposals made by him in years past-proposals to which the most strenuous opposition was offered by directors less far-seeing and artistically minded. Of Sir George Grove I should further say that he is one of the most ardent music-lovers 
England has ever had in her midst. His idols are Beethoven, Schumann, and Schubert, and his veneration for the last-named master carried him so far that he proceeded, in company with his friend Arthur Sullivan, to Vienna, and there made such researches that he succeeded in unearthing a great many most important works from the pen of his beloved composer which might perhaps otherwise have remained for ever unknown. To Sir George Grove's services, when he was director of that institution, the Royal College of Music undoubtedly owes its present high position among our musical academies; while, lastly, be it recorded of this learned and amiable musician that the Dictionary of Music, to the completion of which he devoted so many years of his well-spent life, will serve for all ages as a comprehensive textbook and work of reference, the value of which to students of musical history cannot possibly be over-estimated. 


\section{CHAPTER XL.}

\section{A BATCH OF CONDUCTORS.}

Otto Goldschmidt and the Bach Choir-Jenny Lind and the chorus-Mr. Henschel's Symphony Concerts-Sir Joseph Barnby-The Royal Choral Society-An eclectic musician -Expert opinion on music-hall ditties-Guildhall School of Music-Dr. Henry Wylde-The 'New' Philharmonic Society in 1852 -Wilhelm Ganz-Hector Berlioz-His Romeo and Juliet symphony-Lindpainter and SpohrHans Richter-Other German conductors-Wagner's music in England-Concerts without 'star' singers-The conductor's apotheosis - Richter's memory - Score of Die Meistersinger - The doctor at rehearsals.

I HAVE not yet exhausted my list of conductors. In this continuation series the first name that occurs to me is that of a very old friend, Otto Goldschmidt. Many men there are who have become known through marrying a celebrity; but not so Otto Goldschmidt, who would have attained a position for himself even if he had never met Jenny Lind. Excellent pianist, capable composer, and all-round musician, he is 
a thorough artist if ever there was one. As conductor he will be chiefly remembered through having organized and directed the Bach Choir.* And let me here record a fact which is not generally known. Jenny Lind, who entered with the enthusiasm natural to a true artist into every work her husband undertook, frequently lent him invaluable aid by singing in the chorus. What other 'star' of the first magnitude would have deigned to carry her love of art to such a pitch? Amongst Otto Goldschmidt's compositions the best known was his oratorio, Ruth, in performances of which his accomplished wife frequently took part.

Coming to present-day conductors of high standing. a good deal might be written concerning Mr. George Henschel, but no purpose could be served by recapitulating facts familiar to all lovers of music. There is nothing to add to them; but, in passing, let me pay my humble tribute to what this distinguished conductor and gifted musician has accomplished in the cause of his art in connection with the Symphony Concerts. In London, where, compared with large Continental towns, we hear so little high-

* Professor Villiers Stanford succeeded Otto Goldschmidt as conductor of the Bach Choir. 
class orchestral music, the impetus given to this class of performance by George Henschel has been of incalculable advantage to the great musicloving and music-understanding public.

Few musicians of the present age enjoy a greater reputation than that highly-esteemed composer and conductor, Sir Joseph Barnby. To over-estimate what he has done for choral singing would be impossible. It is at his performances of oratorios and other sacred works in the Albert $\mathrm{Hall}$ that the finest choral singing in London is to be heard; for the interpretation of standard and solemn works by the forces which he directs is, in my opinion, unrivalled. But in years long past, when he conducted oratorios in Exeter Hall-that pious spot now dedicated to meetings which 'come with the merry May'he displayed conspicuous aptitude for Church music.

A musician of more eclectic and catholic tastes I have never met. I believe that, as an erudite and tolerant musician, he has no sympathy with those superior and cantankerous persons who turn up their noses at everything and anything not made in modern Germany, and affect a cold indifference to all composers who are old-fashioned enough to believe that there still exists a public 
willing to be charmed by melody, pure and simple.

I remember hearing him deliver a speech--or it may have been a lecture-in which he forcibly enunciated his views on this score, and frankly proclaimed his capacity for appreciating a musichall song, provided it be a good music-hall song, and remarked that he had derived intense pleasure from listening to the graceful and piquant strains of light lyrical works, and poor, despised comic operas. And I quite agree with him. Sir Joseph, as all the musical world knows, is now the Principal of that important and useful institution, the Guildhall School of Music, and I cannot close this brief reference to him without bearing testimony to the splendid work he has done in the interests of the civic college.*

Before concluding my somewhat portentous list of conductors, I should repair an omission of which I was guilty in one of the preceding chapters, and that was in failing to put on record the establishment by the late Dr. Henry Wylde, in 1852 , of the 'New' Philharmonic Society. In the management of these concerts he was two years later joined by Mr. Wilhelm Ganz, who, on

* The above passages relating to Sir Joseph Barnby were written before the lamented death of the distinguished musician. 
Dr. Wylde's retirement, afterwards became the sole director and conductor.

Under Mr. Ganz's able and spirited control, these concerts gave promise of enjoying lasting prosperity, and it is to be regretted that after five years circumstances necessitated their permanent abandonment. Not only were many classical works performed under the new régime, but not a few of the greatest artists of the day took part in them, such as Rubinstein, Hans von Bülow, Saint-Saëns, Pachmann, Madame Essipoff, and Sophie Menter.

By the way, one of the first (if not the first) of the 'New' Philharmonic conductors was that illustrious composer, Hector Berlioz, who conducted his Romeo and Juliet symphony at one of the concerts, while in 1854 one of Germany's most famous conductors, Lindpeintner, much esteemed as a composer in Carl Maria von Weber's style, occupied the responsible post. It was also filled by Spohr.

The illustrious name of Charles Hallé should, of course, figure in this chapter, but as I have dealt with that distinguished conductor and composer elsewhere, I have nothing to add.

I cannot conclude my record of musicians famous for their mastery of the bâton without 
some allusion to Dr. Hans Richter and his compeers, such as Mottl, Hermann Levi, and Nikish, all worthy followers of Richter as exponents of Wagner. But enough is it for me to lay emphasis on the wondrous change wrought in England of recent years in this connection, thanks to such men as Hans Richter. For whereas in former years no sort of concert in London attracted a large gathering unless it brought to the platform a vocal or instrumental 'star' distinguished in the musical firmament, we now behold the spectacle of an audience, crowded, alert, and expectant, drawn only by the magic name of a Richter or a Mottl.

In the old days the poor conductor, who had to work so hard before he got his forces to a sufficiently high level of excellence to ensure a finished performance, was a mere harmless and necessary figure in a scheme of attractions in which his 'drawing' capacity was not reckoned. Now he is a veritable power in the land of music, and his name is printed in the type formerly accorded to none save a Patti, a Jenny Lind, a Liszt, or a Rubinstein.

There are one or two points in connection with Hans Richter's extraordinary genius, as to which I ought to add a line. His close familiarity with 
the works of the masters of Bayreuth-as, indeed, with all the works he conducts-is such that he can write out from memory the full score of any one of them. It is well known, I believe, that the first complete score of Die Meistersinger was copied out by Richter, who stayed with the composer for that purpose. But few people can be aware of the extraordinary personal knowledge. of every instrument that he brings to bear on the training at rehearsals of his orchestra. In order to indicate how he wishes any particular passage interpreted, he frequently takes an instrumentbe it string, wood, wind, or brass-and plays the phrase himself. 


\section{CHAPTER XLI.}

THREE ENTERTAINERS.

John Wilson-A thorough artist-Two boon companionsCorney Grain as a law student-The Old Bailey renounced-Theatrical wig and gown-The author in Corney Grain's robes-My visit to a lunatic asylum-A strange 'partner'-Astonishing recognition-The entertainer's manner and methods-'The idol of the 'unco guid' -A peep at Tunbridge Wells-'Abandon hope . . .'Pink Dominoes whitewashed-Good-natured chaff-George Grossmith-A modern Theodore Hook-A cause céleltre -The season 'crush '-How Gee-Gee spcofed the guests -A welcome cable-A letter from Corney Grain.

Is giving some account, earlier in this book, of certain public entertainers who, to attract audiences, partly relied on sources other than musical, I had occasion to speak of John Parry, Henry Russell, and Albert Smith. It is now time to mention two of their successors, who for years past have afforded infinite pleasure to the young and old of this present generation. But 
before writing of our modern humourists of the platform, I must be allowed to devote a line or two to John Wilson, who, when first I came to England, was among entertainers a great public favourite. He was, in reality, an excellently trained singer; but I mention him in this place because he never assisted at regular concerts. contenting himself with recitals which used to last about two hours, and in which he received no help from any other artist. His entertainment was limited also in another particular, in that it consisted solely of Scotch songs. These, however, were so wisely chosen and so ingeniously varied, and sung withal in a manner so perfect and with phrasing so refined, that monotony was effectually kept at bay. There was, indeed, such a charm about the performance that, despite my utter ignorance of Scotch dialect, I experienced the greatest delight in listening to it.

Coming to later days, who shall say how much gloom and melancholy have been dispelled, how many troubles and vexations have been forgotten, under the genial influence of the sparkling witticisms of Corney Grain and George Grossmith, inseparable friends, who chaffed everybody - even one another-but always good-naturedly. What a capital sketch it was, by the way, which 
appeared one week in Vanity Fair of these two outwardly dissimilar popular characters walking arm in arm. No contrast could have been greater or more amusing.

Corney Grain had studied for the bar, as did many other members of his family, but the precincts of our civil and criminal courts suited him not, and there came a time when his wig and gown were no longer donned in the interest of litigants, co-respondents, and malefactors, and only found their way to the head and shoulders of individuals who had not 'eaten their way' to the Bar. I myself was among the number.

The occasion was a fancy-dress ball given by Mrs. Douglas Murray, in Portland Place, for which my friend was good enough to lend me his discarded articles of legal attire. Need I say that these were the slender days of Corney Grain, when his clothes would not have hung like a sack on any other frame but his, and that had I presented myself in after years, even in a fancy-dress ball-room, attired in any apparel of his, my ap. pearance might have given rise to a belief that I was trying to figure as an inmate of Earlswood or Bedlam ?

By the way, if my readers will pardon the digression, I should like here to narrate a strange 
experience, of which I am reminded by the incident above recorded.

Some years ago I was staying with some friends in the county of - One afternoon my host suggested that I might like to accompany his other guests to a ball which was to be given that evening by some 'near neighbours,' and which promised, he said, to be unusually interesting. I readily assented, albeit my dancing days were long since past, and then it was that my genial host, whom I reminded of this fact, imparted to me the intelligence, for which I was hardly prepared, that the dance in question was to take place at the Criminal Lunatic Asylum in the county. Thereupon I confessed to having no feverish desire to become acquainted with any of the inmates of such an institution; but on being assured that they were not 'dangerous'-some of them, indeed, possessed, I was told, most engaging traits-I consented to join the party.

I did so, and later in the evening I accordingly found myself on a 'floor' which, had I been younger, would, I feel sure, have induced me at once to foot it nimbly. But, as I have said, my ball-room days were over, and so, holding aloof from the dancers, I contented myself with watching the demeanour and bearing of the strange 
and incongruous throng in whose midst I found myself.

While I was thus engaged the friend who had brought me thither came up to me, in company with one of the medical men attached to the asylum, and the latter, after being introduced to me, asked whether I would entertain any objection to dancing with one of his charges, adding that some of them were extremely sensitive and might take offence at my remaining in the background. Truth to tell, the invitation tempted me but little; nevertheless, I allowed myself to be persuaded into taking a partner for the set of quadrilles just about to commence.

Thereupon I was formally presented to a lady whose appearance was not calculated to revive in me that love for dancing which the prospect of tripping it with a fascinating partner might have inspired in one even of my years. This particular inmate, who, on being introduced to me was, unlike Niobe, 'all smiles,' was dressed 'up to the eyes,' as the saying goes, while such is the license apparently granted to dames and damsels 'detained during Her Majesty's pleasure,' that she had applied with no sparing hand the rouge pot and powder-puff to her face, while her chevelure was, if her own, of a hue which I 
for one had never seen before, even in a ballroom.

But the surprise I experienced at the appearance of this singular creature was as nothing compared to my astonishment on hearing the exclamation that fell from her enamelled lips after the medical attendant had performed the ceremony of introduction.

-Wonders never cease !' she said. 'Who would ever have thought of meeting you here, $\mathrm{Mr}$. Kuhe?'

Utterly bewildered, I muttered something about my pleasure at finding myself in such agreeable company.

'Why,' she continued, interrupting my banalities, 'I used to go to all your concerts in Brighton.'

Here was an interesting 'case' indeed, and the mystery thickened when my partner, whose delight at meeting me was somewhat disconcerting, proceeded to inquire, with undisguised interest, after various people known to me personally or by name, with whom she said she was acquainted.

The quadrille over, I lost no time, needless to say, in ascertaining the identity of the lady who was formerly such a constant patron of my concerts. My inquiries led to the discovery that 
she bore a name notorious in the annals of latterday crime, the scene of which was laid in Brighton, and the victims of which were a number of children to whon she had sent poisoned sweetmeats. An attempt had been made by this unhappy creature to fasten the guilt on others, jealousy being the alleged cause of her murderous designs; but a plea of insanity was set up and successfully established, with the result that she found herself comfortably housed in the asylum within the walls of which I met her.

No description of the manner and methods of the brilliant entertainer, my recollections of whom I must now resume, is here necessary. They are in everybody's memory, for the pleasant hours spent in St. George's Hall-and it is wonderful that so lugubrious a building should be identified with any form of pleasure - are recollections almost of yesterday. He not only contrived at all times to amuse hardened playgoers and blasé pleasure-seekers, but materially assisted in the development of a form of mild and innocuous dissipation for a large body of people peculiar to this soil who have a deep-rooted conviction that over the portals of every theatre are emblazoned the words, 'Abandon hope, all ye who enter here.' 
Why, not many years ago, when staying in Tunbridge Wells-a town noted for the dissenting proclivities of its inhabitants-I was talking on this very subject with the manager of the hall, which in that picturesque resort serves as a theatre and concert-room combined, and he informed me that again and again had the suggestion been made to him that a temple of the drama would supply a long-felt want in that quaint old town, but that the feeling against anything called a theatre was so strong that all hope of making such a scheme pay had to be renounced. Nevertheless, the entertainments-musical and dramatic -given periodically in the 'great hall' were highly successful; and people who would regard themselves as 'lost' if they witnessed a performance of Hamlet given in a theatre, flocked, to my knowledge, to the aforesaid building to enjoy the risky fun of that Anglicized French farce, the Pink Dominoes.

Corney Grain possessed the rare gift of being able to evoke laughter and applause from the very people against whom his satire was levelled. But, then, his sarcasm was always good-natured and innocent of offence, besides which, as a keen observer and a man of discernment, he counted on the inability of nine out of every ten members 
of his audience to recognize in themselves the butts of his humour.

'Chaff them,' he always used to say, 'as much as ever you like. They are sure to think you are alluding to their neighbour in the stalls, and will enjoy the fun all the more on that account.'

As everybody knows, George Grossmith, wittiest of humourists and most genial of men, has of late years followed in the footsteps of his lamented friend, meeting both here and in America with enormous and well-deserved success. But, unlike many performers whose mission it is to amuse the public, 'Gee Gee,' as he is familiarly called, is every bit as witty and entertaining off as he is on the platform.

And I hope he won't object to my adding that, like the immortal Theodore Hook, he loves a good practical joke. Possibly for that reason was he selected for the part of the Governor of Elsinore in Messrs. Gilbert and Carr's His Excellency, though, unlike that amusing but unprincipled official, his practical jokes, in common with his sallies, are never unkind.

Some two or three years ago, at the time when a cause célèbre-which created an extraordinary sensation in social circles, and in which a wellknown baronet was involved-was in course of 
hearing, I was present at a season 'crush' at which Mr. Grossmith, among other artistic celebrities, had been entertaining the guests. The latter were waiting in the flower-bedecked hall for their carriages-the usual difficulties and delays in this connection being encounteredwhen, in a moment of silence, my irrepressible friend, assuming a voice foreign to his own, shouted in stentorian tones :

'Sir —_ ' - carriage stops the way.'

The name he had proclaimed was that of the aforesaid baronet, of whom everyone in society was talking at the period, and, needless to say, a moment of intense excitement followed, consequent upon the eagerness of all to behold the gentleman of whose supposed presence they had been unaware.

Grossmith's kindness and generosity are proverbial. Let me recall, as an instance of his unfailing good-nature, how, on hearing, whilst in America entertaining Cousin Jonathan, that a concert was being organized in London in celebration of the jubilee (1894) of my arrival in this country, he at once cabled from the States to his friend (Mr. Vert) that it would give him great pleasure to be numbered among the artists who were to rally round me on that occasion; and, as luck and his good-nature ordained, his welcome 
Deacest Briss havetts

$\checkmark$ am oh

Bugithon! Son are at oreppor.! Put a few yout of eca betares no.'von athat a guef. ho knattew-Perk opo atoms

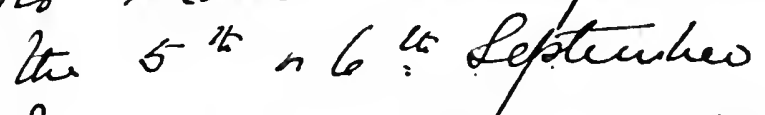
$I$ may nentivo in tom cuchles ahell aic ross that gralf and thew me wll sit = alone - 
- Iojettur - in the oamb. (or is it beach) it then pebbles mis the roa. $\checkmark$ Naw you dea Mana who s. hiving a white. -imaskod Ejer. Iong attue Ahe on is flestiv mer Some theditay frawi Drelesi as Hombourn sich Wantrug. I am ysa HambugfinCanest Kaniets i borhing to thio. ohe muses he tornic - whatsi that tonic. 
atah yong lady-fairef ceedring fain to crew. with a realy bluokther uares a -...buk 2no! that wa c...collate 5o th the tonde millo ne' Annelyan hown my niane. ' I'le ud. tew it.- I ouly oay it. is that of ne of the mont deototed of zom hiliow atruiers.

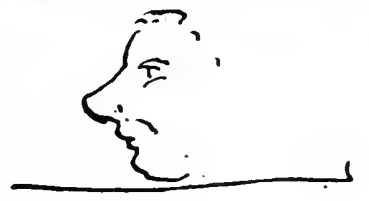

To face p. 29 r. 

appearance at that concert signalized his rentré in London after his transatlantic triumphs. By such kindly and spontaneous actions as this does George Grossmith endear himself to all and sundry, and win the friendship of everyone with whom he is brought into contact.

I give here a letter of Corney Grain's, written to my daughter when she was a very young girl, full of genial chaff, and therefore characteristic of the writer. 


\title{
CHAPTER XLII.
}

\author{
MR.J. M. LEVY.
}

My early struggles-The friend of young artists-The Sunday Times-An artistic symposium-The Daily TelegraphPredictions falsified-The first penny daily paperFlorence Cottage-An art connoisseur-Musical and theatrical celebrities - The actors' counsellor-Hints to managers-Social entertainments in Grosvenor Street-A memorable duologue-Return of the wanderer-The great actor's first call-A dinner to Henry Irving-Sir Julius Benedict-Reminiscences lost to the world-Mr. Lionel Lawson-The Queen's, in Long Acre-The Gaiety - Sir Edward Lawson-Criticisms in the Daily Telegraph -Some contributors thereto.

Probably to no one prominently connected with art, literature, music, and the drama, will mention of the name of the late Mr. J. M. Levy fail to recall cherished memories. Few men of his time did more for art, or took a keener and more intelligent interest in all that appertained to it, than the open-hearted gentleman who became, subsequent to my first knowing him, the proprietor of 
a journal which he made a veritable power in the land. Looking back now over a number of years -recalling early days of struggle and disappointment, and a later period in which I enjoyed such success as I may have attained in the profession I adopted-one figure stands out prominently, and brings back to my mind recollections which I value more than any in my long career-that of one of the staunchest friends I ever had in this country or that of my birth-Mr. J. M. Levy. From the time of my first introduction to him in $\mathrm{I} 846$, to the day of his death in I 889 , he remained to me the most loyal and valued of friends, ever ready to give me wise counsel, sympathize with me in times of trouble and stress, and rejoice with me when fortune smiled.

When I first became acquainted with Mr. Levy, then the proprietor of the Sunday' Times, he had a house in Doughty Street, where he was wont to entertain, with a hospitality which ever remained one of his most distinguishing traits, men of culture, of literary ability, and artistic promise. It was while he was living here, in the early years of our acquaintance, that he became the proprietor of the then recently-established Daily Telegraph, and the virtual founder of the first London daily penny journal. What obstacles had to be en- 
countered in this enterprise, what prophecies of failure and disaster were uttered by the conservative wiseacres of the time, with what persistent energy, extraordinary tact and sound judgment the undertaking was ultimately carried to success, are matters with which it is not my province here to deal.

The friendship so happily formed at that early period ripened with time, many events happening to foster and preserve it when, in after years, I was a constant visitor at the house of Mr. Levy in Grosvenor Street.

I may here recall that shortly after his marriage, at the age of nineteen, Mr. Levy took a pretty and healthily-situated bijou residence, which he subsequently christened Florence Cottage (after his youngest daughter), in Ramsgate, a town of which he was always very fond, and which he yearly visited in the summer months, as he did Brighton in the autumn and winter, when the season at the Queen of the South was in full swing. The transformation which, as time went on, he wrought at his dearly-loved Florence Cottage, revealed the hand of the artist and the lover of the beautiful in all that concerns environment. Acquiring many acres of surrounding property in the way of land and gardens, he so 
enlarged his picturesque and cosy country retreat that the simple and unpretending word 'cottage' fell strangely on the ears of those finding themselves within its hospitable precincts. It was here that the owner spent some of the happiest days in his long, active, and honourable career; it was here, surrounded by his relatives and friends, and mourned by all who were ever privileged to know him, that he passed away after a lingering illness.

As a private gentleman and personal friend rather than as the proprietor of the remarkable journal which he owned, will I speak of this versatile and gifted man. When I first knew him I was a frequent visitor at his house, and in later years, when, having more time and leisure to devote to entertaining, his residence was a centre of artistic and social life, he would never allow a day to pass without my seeing him, so united were we by ties of friendship. Even when he went on the Continent he was good enough to invite me to accompany him, and he never neglected an opportunity of introducing me to people whom he considered it to my interest, as an artist, to know. Kind and affable to all who visited at his house, to no one was he more so than to actors, singers, literary folk, and artists generally. More especially did he take a lively interest in every- 
thing and everybody connected with the stage and with the musical world. His experience and widespread knowledge were sufficient to inspire in all who thus approached him the utmost confidence.

How many interesting personalities I met, and how many valuable connections I was able to form through Mr. Levy, will at once become apparent when I enumerate a few of those who frequently enjoyed his hospitality. I can only mention a tithe, of course, and will do so in the order that their names occur to me. Confining myself wholly to representatives of the artistic world who were constantly to be found at his house, I can call to mind Mr. and Mrs. Charles Kean, Mr. and Mrs. Keeley, Charles Mathews, Sothern (the original 'Dundreary'), Benjamin Webster, Morris Barnett, John Oxenford, Edward Dicey, Montagu Williams, John Hollingshead, the Alfred Wigans, the Bancrofts, the Kendals, Arthur Cecil, the Marquis de Caux and his wife, Adelina Patti, Christine Nilsson, Titiens, Ethelka Gerster, Pauline Lucca, Sembrich, Sims Reeves, Thalberg, Rubinstein, Ernst, Piatti, Sir Michael Costa, Sir Julius Benedict, Mapleson, Sir Augustus Harris, Corney Grain, 'Johnny' Toole, Mary Anderson, John Hare, Edmund Yates, H. J. Byron, Sir 
Arthur Sullivan, F. H. Cowen, and last, though assuredly not least, Henry Irving, who, with his friend and aide-de-camp, Bram Stoker, was a frequent visitor, and among Mr. Levy's most intimate friends. Indeed, our host, keenly artistic as I have said, and the first to recognize true genius in any branch of art, had a fervent admiration for the Lyceum manager, and never tired of singing his praises, while he sought his society more, perhaps, than that of any other man. Many artists who now enjoy a high and enviable position in their respective spheres, but who were at that time still ascending the ladder of fame, could bear witness with me to the unfailing kindness and courtesy of the counsellor and friend whose death was an inestimable loss to the dramatic and musical professions, whose best interests he had so much at heart.

Of Mr. Levy's experience and shrewdness many theatrical managers of note would often take advantage, and it was quite a common thing for a manager, before producing a new play, reviving an old one, making an engagement, or investing money, to consult 'Papa' Levy, as he was invariably called by his more intimate friends; and I have known of cases where his advice in such matters proved of the greatest value, and 
revealed him in the light of that rara avis, a prophet in his own country.

I was only one of many friends and protégés whose career he was the means of starting, and whom, in subsequent years, he never forgot or neglected. As for the intellectual and artistic treats his friends enjoyed within his hospitable walls, they were without number-brilliant talk from such men as Charles Kean and Sir Edwin Arnold, singing by Patti and Nilsson, the playing of Thalberg or Rubinstein, comic sketches by Corney Grain or George Grossmith, recitations by Irving or Toole. I shall never forget a comic duologue I once heard there (now many years ago) by Mrs. Bancroft (then Marie Wilton) and Arthur Cecil. Nor would I efface from my recollection another occasion, which was brought about in this way :

When Henry Irving returned to London, after his first tour in America, he called almost immediately on Mr. Levy, in Grosvenor Street. I happened to be visiting at the house that afternoon, and vividly recall my friend's surprise and delight when the disting'ished actor walked into the room. Before there had been much conversation Mr. Levy said, 'Henry, unless you have made any other engagement, you must have your 
first dinner here with me, quite informally, of course, as it is too late to arrange much more than a family gathering.' Irving at once assented, whereupon Mr. Levy said that I must come too. $\mathrm{He}$ also despatched a like invitation to Sir Julius Benedict, who was a persona grata in Grosvenor Street, and another to his old friend, the late Mr. Whitehurst. These, together with Miss Matilda Levy, constituted the 'party;' and a more delightful, homely and entertaining evening could not be imagined. The honoured guest's American impressions would fill a small volume, could I remember them, while the distinguished and amiable composer of the Lily of Killarney was in great form. A brilliant and humorous conversationalist at all times, he excelled himself on this occasion, recounting innumerable recollections of notable events in his varied career, and narrating, with indescribable esprit, anecdotes concerning artists past and present. I cannot help deploring that so gifted and witty a man as Julius Benedict should have died without giving to the world a volume of his reminiscences. Had he done so, a rich store of interesting events, many of them unrecorded, would have been given to a public always eager to learn more of artistic celebrities and the world in which they lived. 
I cannot close this chapter without making brief reference to some of the members of $\mathrm{Mr}$. Levy's charming and accomplished family, and to one or two of his relatives. His half-brother, Mr. Lionel Lawson, was a well-known figure both in London and in Paris. In the management of the Daily Telegraph, of which he was part proprietor, he took no active share, but, in common with Mr. Levy, he evinced a warm interest in everything connected with the stage and those associated with it. He built two theatres, the Queen's, in Long Acre, and the Gaiety. He was liked by everyone for his kindness, bonhomie, and genial wit, and was, in short, a great favourite with all sorts and conditions of men. A great portion of the immense fortune which he left was inherited by his nephew, Edward Lawson, who had many years previously adopted his uncle's name. No need is there for me to say anything of the popularity of Mr. Levy's eldest son, than whom a more affable and kind-hearted fellow never breathed. Years ago, when his father's health was beginning to fail, he worked like a Trojan in the interests of the paper which he now controls with such indefatigable spirit (and of which, by the way, my old friend, Mr. J. M. Le Sage, is the managing editor). All who know Edward Lawson 
rejoiced when, three years ago, the honour of a Baronetcy was conferred upon him. Sir Edward, I may add, is as loyal a patron of the drama and as fond of the society of its exponents as was his father before him.*

By the way, I should have mentioned that in the later years of his long and active life Mr. Levy devoted himself solely to that portion of the Daily Telegraph which deals with matters theatrical and musical. In this connection probably few persons living know to what extent he helped to stimulate a healthy and artistic public interest in music and the drama. This he did by devoting far greater space to theatrical productions and musical events than was accorded them in any other daily journal-a tradition adhered to up to the present day, although, of course, far more prominence is now assigned to music and the stage in all newspapers than was the case formerly. But Mr. Levy was the first to lead the way in this direction, and he showed his keen insight and sound judgment by securing for the purpose such critics, for example, as Mr. Joseph Bennett, Mr. Clement Scott, and Mr. Beatty Kingston.

* Lady Lawson is the daughter of the late Benjamin Webster, who left behind him as great a name as any English actor of his time. 


\section{CHAPTER XLIII. \\ MUSICAL ASPIRANTS.}

An incurable malady-Young talent-Importunate friends of beginners-'So and So's'-Trials and tribulations of impresarii-My opinion sought under curious circunsstances-The strange gentleman-An extraordinary request -A comic version of the Erl King-Common form of insanity-The other side of the picture-Two successful débutantes-Miss Margaret Macintyre.

IT was once suggested to me that some account of my experience of musical beginners, by which I mean would-be singers, pianists, violinists, and the like, might prove rather entertaining reading. And so I think it would. But it would be difficult to do justice to the subject without giving grave offence to many victims of the 'publicperforming fever' who, at different times, have besought my aid. Still, I may give one or two examples of how people who, like myself, occasionally organize concerts are expected to encourage young 'talent,' and how their time is often taken up, to the benefit of no one, in 
hearing 'so and so, who has a lovely voice, and is bound to get on,' sing in private. How many 'so and so's' I have had to listen to in my time I could not say. And the worst of it is that, save on the rarest occasions, I have been able to do nothing for them. It is not because one is unwilling to help on beginners, but simply because the opportunities for so doing are few, while in many cases, alas! the young musical beginners are not musical at all, but hopelessly incompetent.

And where the artist in whose behalf assistance is sought happens to be the protégé of an old or intimate friend, the task of refusing aid becomes a very delicate one, and a little diplomacy has to be called into play.

Here is a curious letter in which my advice was sought twenty-three years ago:

' Dear Sir,

'Would you kindly favour me with your opinion of my children's musical abilities? Could they attain a position-say, such as Madame Arabella Goddard's, or are they only average players? Your answer will greatly oblige,

'Yours, etc., 
Not in the expectation of hearing embryo Arabella Goddards, but solely to oblige their inquiring father. I heard the infant prodigies play. Having done so, I could not honestly predict for them a brilliant future, nor could I bring myself conscientiously to pronounce them 'average players.' They were about the worst even I had ever heard.

I shall never forget a visit paid me in Brighton by a stranger, who, bringing no letter of introduction, made me a most extraordinary offer. This gentleman's manners were charming, and I afterwards learnt that he belonged to a good family; but the suggestion he made was so preposterous that for the time I really believed that he had escaped from a lunatic asylum. He had studied music seriously, but had discovered that his forte lay in a comic vein. In fact, he possessed (this on his authority only) a real genius for singing comic songs-negro ones in preference-and his idea was to establish a large social connection in the way of singing at private parties and 'at homes'; but it was essential, he said, first to achieve a kind of professional status, so that he could command high terms, and this could only be done by singing in public at an important concert, where he would be the only 
'comic singer,' and on that account alone would 'create a sensation.'

Then came the staggering suggestion that I should assign him a prominent place at one of my big concerts-a classical one for choice, he saidand allow him to sing one of his rollicking, sidesplitting effusions. But it was to be a musical joke in more senses than one, because this comic genius's perception of humour extended to the idea of his being announced to sing something legitimate, such as The Erl King, so that the audience might be pulverized with astonishment when he commenced his humorous ditty.

I will not disclose the price this extraordinary individual was willing to pay for a début under such circumstances. Suffice it that he was ready to buy up seats equivalent to a very substantial sum. And when I refused, firmly but politely, he looked too sorrowful and downcast ever to sing a comic song again. Unabashed, however, he subsequently wrote to me urging his suit, but from that day to this I have never set eyes on him. Often have I wondered how the audience would have received that comic version of The Erl King. Possibly they would have preferred it infinitely to something strictly classical.

In common, doubtless, with many other concert 
givers, I have had remarkable experiences of persons-usually men-who, on the advice of their friends, have given up the profession in which they were engaged, and out of which they were making a good income, in order, as they thought, to take the world by storm as singers or players. This is quite a common form of insanity, and one of the very saddest I know of. For it is grievous to find a man, as I often have, at an age when it is too late to begin anything, throwing over of his own free will a settled income (in many cases a large one), to take up one of the most precarious callings in the world without possessing the talent necessary to stand the smallest chance of success.

And having said so much on that side of the picture, I am glad to be able to say-if I may do so without appearing egotistical-that it has been my pleasure and good fortune in the course of my career to have the opportunity more than once of giving a helping hand to young artists of genuine promise and ability, and to have been the means of introducing to public notice singers and instrumentalists who have since risen high in their profession. Thus, to mention only two cases, it has always been a source of pride to me to have been the first to lead on to the concert 
platform those charming and gifted singers, Miss Marguerite Macintyre and Mademoiselle Antoinette Trebelli, both of whom made their initial public appearance under my auspices, the first-named in the Brighton Dome, and the latter at St. James's Hall. 


\section{CHAPTER XLIV. \\ OUR OPERATIC MANAGERS.}

Benjamin Lumley-Opera in 1845 - Some famous dancersTaglioni and the swaying sisterhood-Lumley and his competitors-Deserted by his singers-Loyal LablacheThe manager unbaffled-A rival flourish of trumpetsThe Covent Garden Syndicate-Jenny Lind to the rescue-Rentrée of Sontag-Titiens and PiccolominiFrederic Gye's enterprise-English opera at Drury LaneThe 'poet Bunn'-Mr. Punch in Trouble-Harrison the tenor-Louisa Pyne-Likeness to Queen Victoria-Gye's 'stars'-In the ascendant-My relations with the manager-Concert at the Floral Hall-Italian opera at the National Theatre-E. T. Smith and Mapleson-The latter beloved by artists-Array of talent-Signor LagoGayarré-The sisters Ravogli- 'Young Italy' at the Shaftesbury Theatre-Cavalleria Rusticana-A Russian opera-Eugene Oudin-Mr. D'Oyly Carte and the Royal English Opera-Sullivan's Ivanhoe.

IN 1845 , the year in which I settled in this country, Benjamin Lumley was the leading spirit of Italian opera in the Metropolis, and under his spirited and able direction both the lyric and the choregraphic arts flourished. In those days, the 
ballet was a great feature of the opera, and amusement-goers whose memories do not carry them back to that time can in my opinion have no conception of what dancing really should be. I quite admit the grace and agility of our present-day Letty Linds, and the skirt and 'serpentine' dancers who are held in such high esteem by the modern jeunesse dorée; but still, I maintain, at the risk of meeting with flat contradiction, that there was a poetry and beauty about the pirouetting of Taglioni, Fanny Elsler, Cerito, and Carlotta Grisi, which has never been equalled since.

To return to Lumley, who was undoubtedly one of the most enterprising managers of that or any other time, the year that followed my arrival (1846) was the last in which he held absolute sway. For there came other Richmonds upon the field, as he discovered to his cost, and on the last night of the season, when he wanted to renew the contracts with his artists for 1847 , he was informed that all the singers (Lablache excepted), the orchestra, chorus, conductor, and the entire staff had entered into agreements with an opposition establishment.

No one nowadays can possibly realize the difficulties presented by such a situation as Lumley was called upon to face. An advertisement in- 
serted in the papers at the present day for a first violin or a bassoon player would elicit at least fifty answers. But not so in Lumley's time, when London boasted practically only one orchestra, which was sufficient to serve all purposes by reason of the fact that the opera performances only took place three times a week, and concerts were given on the days that the opera was closed. The mere fact that his orchestra had given him notice meant that Lumley would have to go into the highways and byways, and search in Continental cities for efficient substitutes. The same with the chorus, who guitted en masse, and anybody less resourceful than this astonishing manager would have' been at his wits' end to carry on so stupendous an undertaking in the circumstances. But far from being downcast or crestfallen, Lumley even found the heart to jest about his dilemma. Pulling himself up with the dignity that became a man who always wore a white waistcoat, he said to me one day, in speaking of his troubles :

'Ah, Kuhe, it's an ungrateful world! They've all left me except dear old Lablache ; and he's as staunch as he is stout.'

Everyone considered poor Lumley's case a desperate one, and wiseacres predicted his speedy retirement from the scene of so many triumphs. 
But the manager was far too astute and far-seeing to give up the battle without a struggle, and his extraordinary perseverance stood him in good stead for a time.

The rival concern had been duly opened, with a flourish of trumpets, at Covent Garden, in the syndicate for running which were Delafield the brewer, Persiani, and Frederick Beale. But at this time there came upon the scene the incomparable Jenny Lind, who enrolled herself under the banner of the plucky Lumley, and proved such a mighty attraction that the opposition house was, in colloquial parlance, 'nowhere,' and the directorate, unable to offer their patrons inducements in any way proportionate to those held out by the lessee of Her Majesty's Theatre, came to grief. For a time, then, Fortune continued to smile upon Benjamin Lumley, thanks to the return in the following season of Jenny Lind, and to the subsequent reappearance of Henrietta Sontag (Contessa Rossi), who was induced, after twenty years, to emerge from her retirement, and once again charm her old admirers and astonish a new generation.

Two other attractions of the first magnitude also came to Lumley, in the persons of Titiens and Piccolomini, and all looked rosy enough until 
the appearance at the head of affairs at Covent Garden of Frederic Gye struck a death-blow at the other establishment. The enterprise and the power of organization which the new-comer brought to bear on the undertaking proved too much even for Lumley, and he had perforce to give up the fight.

By the way, when I first came to London, Drury Lane boasted a scheme of English opera, of which the guiding spirit was the famous Alfred Bunn, called, in a gently ironical appreciation of the unconscious humours of his lyrical efforts, the 'Poet Bunn.' His action against Punch, in whose genial columns much innocent fun was levelled at the manager, is matter of history.

Harrison, the great English tenor, and father of Clifford Harrison, was Bunn's chief singer. Together with that accomplished and popular vocalist, Miss Louisa Pyne, Harrison in after years carried on several seasons of English opera at Covent Garden, and there produced works by Wallace-including Lurline-and Balfe, notably the Rose of Castile. In this Louisa Pyne enacted the part of the Queen, and there are probably old opera-goers who can recall how, made up for that rôle, she bore a striking resemblance to our own sovereign. This excited, I remember, a good 
deal of comment at the time; and the extraordinary part of it was that off the stage the charming singer had not a vestige of likeness to Her Majesty.

As for Frederic Gye, he was one of the most far-seeing and energetic operatic managers London has ever known. In previous chapters I have given an account of the début of famous songstresses whom he introduced to the public, among others Adelina Patti and Albani. My relations with Gye were always of the most friendly description, and in business matters he proved himself many a time and oft fair and generous to a fault.

A case in point occurred when I gave my first concert in the Floral Hall. I cannot remember the year, but our arrangement was that I was to avail myself of the services of all his principal artists-including Patti and Albani-and was to pay him $£ 400$ and share with him all the receipts over and above that sum. I also had to defray the cost of advertising the concert. When it was over, however, he was so liberal as to forego his share in the receipts, and would only accept the sum I have named in return for the artists who had taken part in the programme. Thanks to this kindly action on his part, I not only averted a heavy pecuniary loss, which I 
should have sustained had he claimed his full share of the takings, but was even able to realize some profit.

More than one manager in my time has tempted fortune with Italian opera at Drury Lane. The first that I remember was E. T. Smith, although that gentleman, being unversed in the ways of operatic organization, in reality allowed the strings to be pulled by Mr. Mapleson, who ultimately succeeded him, and proved himself to be an entrepreneur of extraordinary skill and resource. By no failure was he abashed, and he allowed no difficulties to stand in his way. His popularity with the artists who appeared under his regime, as well as with the public, whom he always did his best to serve, is too well known to call for comment. Suffice it that Mapleson introduced to the notice of English audiences an extraordinary number of distinguished artists; that he carried on the opera not only in the season but in the autumn (at cheaper prices); and that the operatic representations he gave in the provinces-also during the autumn-were marked by a completeness never before attempted in the interest of our 'country cousins.' On leaving Drury Lane, Mapleson, as is well remembered, tried his luck at Her Majesty's, and the ups and downs he 
experienced within the historic walls of that theatre could be made to fill many volumes. I prefer not to attempt the task.

Among comparatively recent operatic managers, one who made persistent and gallant efforts to revive a taste for a form of art which had then seen its best days was Signor Lago. At Covent Garden he rushed in where many equally astute organizers had feared to tread; but his name is not emblazoned in the roll of those who have accomplished the herculean feat of making Italian opera pay in this country.

At Covent Garden, if I remember aright, the tenor Gayarré was his foremost attraction; but on several occasions has Lago proved his capacity for gauging the public taste. For instance, under his auspices the sisters Ravogli made their first appearance in England, and the manager-a thoroughly kind-hearted fellow, by the wayscored a big hit when, some few years since, he took the Shaftesbury Theatre, and introduced metropolitan amateurs to the melodic charms and dramatic intensity of 'Young Italy' in the person of Pietro Mascagni, whose Cavalleria Rusticana had not up to then been heard in this country.

But Signor Lago's ubiquity was something to marvel at. Some little time afterwards he 
bobbed up again serenely, as the Duc des Ifs used to sing in Olivette, in a theatre eminently unsuited to lyrical representations, and produced an English version of Tschaikowski's opera, Eugene Onegin. If success did not attend this production, the manager, at any rate, earned the gratitude of the musical public in that the few performances that were given derived charm and artistic significance from the appearance in the title-rôle of a singer who won the unstinted admiration of all music-lovers. I refer to Eugene Oudin, whose untimely and pathetic death deprived amateurs of the services of a consummate artist, and was lamented by the many friends to whom he had endeared himself.

I cannot here forego a brief reference to an enterprise, the failure of which was, and still is. deplored by all who have at heart the best interests of native musical art. When Mr. D'Oyly Carte, a manager with whom the whole of the play-going and music-loving public are on the best of terms, conceived the idea of giving to London a perfectly equipped theatre cledicated to English operatic art, all musicians rejoiced, and wished the founder well in his laudable undertaking. But it was not to be. No need is there to recall the conscientious completeness with which the manager carried out 
a scheme fraught with danger to himself but seemingly possible of the brightest results. Everything that tact, taste, and artistic resource could accomplish was done to crown the project with success. Personally, I may say that not since I came to England have I seen a production so admirably cast, so beautifully staged, so perfect in every detail as that which, in the spring of 1890 , introduced to the English public Sir Arthur Sullivan's Ivanhoe. But the prospect of witnessing a series of such works under like conditions of lavish splendour and artistic finish was too good to be realized. The English Opera House is now no more than a memory, the abiding associations of which reflect honour on the man who devised the scheme, and, be it confessed with regret, discredit on those who failed to support it.*

* Reference to the fruitful labours of the late Carl Rosa in the cause of operatic progress in this country will be found in a succeeding chapter. 


\section{$[318]$}

\section{CHAPTER XLV. \\ SIR AUGUSTUS HARRIS.}

Temporary decline and fall of grand opera-London a lyric wilderness-Sir Augustus to the rescue-An organizing genius-A globe-trotting manager-Early attempts at revival-Initial difficulties-A plea for a Government subsidy-Renascence of Italian opera-Native talent encouraged-Three simultaneous performances-Public recognition-A testimonial-Generous gift to academies -Ceremony at Drury Lane-A significant promise'National opera ' in London-Subventions abroad-Court Theatre in Vienna-The Enperor William and the Berlin opera-Superstitions of an impresario-Peacocks' feathers on the drop curtain-The prima donna's birthdaycard-Visit from a coryphée-The dreaded plumes again.

I HAVE spoken, in connection with Signor Lago, of attempts to revive the fallen glories of Italian opera. It is a sorrowful fact that not many years ago the public concealed their taste for grand opera as successfully as they now do their tasteif they have any-for comic opera. There was just this difference, however, that whereas something has taken the place of the latter and 
satisfied fin-de-siècle playgoers who like their fun with a dash of spice in it, there was nothing to supplant Italian opera in public affection, so that musically, or rather operatically speaking, London became a wilderness. How long this state of affairs might have continued had it not been for the indomitable pluck, energy, and determination of one man, goodness only knows. This was Sir Augustus Harris, who, paying no heed to those who prophesied disaster, opened once again the gates of music to opera-lovers whose ears had been stopped, made Covent Garden as spick and span as it was in the days when nobody remembers it, and engaged a first-rate company of artists.

There are several kinds of genius. The lessee of Covent Garden Theatre-and the rest-can lay claim to the title as an organizer. And unlike most other geniuses, he is such a 'hail fellow well met' that you almost forgive him for being one. Now were I to attempt to describe the marvellous doings of a man who, in the heterogeneous interests of a public full of wants, is one day in London, the next in Paris, the following week in New York, and then back again in London before his friends have had time to miss him, I should fail signally. I am informed that 'Augustus 
Druriolanus,' in his spare time, is jotting down notes for his memoirs, therefore I will leave it to him to follow the example of the conjuror, and tell us ' how it is done.'

Years ago, I believe, when Londoners had witnessed the decline and fall of grand opera in their midst, Sir Augustus made up his active mind that he would seize the first opportunity of making at least a gallant attempt to inspire operagoers (who had no opera to go to) with sufficient enthusiasm to support an annual scheme of Italian opera on a scale never before surpassed. The difficulties he had to encounter must be patent to all who reflect on the immense disadvantages under which an impresario has to work in a country where no Government grant is forthcoming, and where the expenses are so enormous that prices have to be charged which to the majority of the public are prohibitive. But Sir Augustus was not the man to be 'frightened off.'

One of these days the renascence of Italian opera in London under the management of Sir Augustus Harris will make very interesting and instructive reading. No reference, however brief, to the fresh lease of life that has come to Italian opera under the present regime should be penned 
that does not make due recognition of the encouragement extended again and again by the impresario to native musical talent. He may give us the best French and Italian singers, bring German operas to our doors, and produce foreign works that have appealed to amateurs on the Continent; but no opportunity has he neglected of bringing to a hearing, under circumstances wholly favourable to the composer's chances, works from British pens, and in this matter he has done that which alone would entitle him to the support and consideration of the English public.

Elsewhere I have referred to the difficulties that befell an operatic manager in London half a century ago, through the unfortunate contretemps of his singers, chorus, and orchestra forsaking him. The chief difficulty, as I have said-let alone the question of artists-was to get efficient substitutes in the orchestra. But what do we find nowadays? That on one and the same night the present manager of Covent Garden can, without turning a hair, so to speak, give a performance of Italian opera at that establishment, a representation of German opera at Drury Lane, and a 'command' performance at Windsor Castle. Twenty years ago such a thing would have been 
impossible. To-day it is accomplished with apparent ease. But it is marvellous all the same.

Having regard to all that he had done, it was hardly surprising that two years ago the popular manager's friends should have desired to present him with some acknowledgment of their appreciation of his labours in the cause of music. A testimonial was, of course, thought of-ideas on this subject somehow never seem to get beyond testimonials and illuminated addresses, the latter constituting a gift which no recipient ever knows what to do with. An influential committee was formed, and in a very short time the subscription list was an exceedingly representative and handsome one.

I recall this pleasing demonstration in recognition of the manager's invaluable services because I would like it to be remembered that Sir Augustus, with characteristic generosity, refused the offer of any personal gift, and, in order to encourage young musical students, requested that the subscriptions be devoted to purchasing three of the best Steinway 'grands' for presentatation to the most deserving and promising pianoforte pupil at the Royal Academy of Music, the Royal College of Music, and the Guildhall 
School. This, surely, was a very kindly and practical act, and three young people, at any rate, must have greatly rejoiced over it.

But this is not all. The speech that fell from the lips of Sir Augustus Harris on the occasion of the presentation, which was made at Drury Lane Theatre by his old friend Sir Edward Lawson, was so significant and interesting that I must crave the permission of my readers to recall a statement it contained. On that occasion the lessee of the national theatre announced that he would not rest until he established a permanent national opera in London. One of these days, in fulfilment of the promise he uttered at the function to which I have alluded, he will, I doubt not, remove the reproach so often levelled against the music-lovers of the Metropolis, that they are too indifferent to support a great musical undertaking of that kind year in and year out.

But what a task it will be! In France, in Germany, in Italy, in Russia, and in Sweden, as most people know, a large subvention is paid by the Courts, states, and municipalities to keep up the opera-houses. Thus to the impresario the Court Theatre in Vienna is rent-free, the Emperor of Austria contributing $£ 40,000$ annually, and making himself responsible for the habitual de- 
ficit. In the same proportion do all the principal theatres in Germany derive assistance, the Berlin Opera House in particular being an enormous yearly expense to the German Emperor, who, at the same time, spends large sums towards maintaining the opera-houses in Hanover, Wiesbaden, and Cassel. Probably it will be a long time before English theatres, dedicated to the highest forms of art, are placed on a similar footing. But if there is one man capable of carrying into execution such a scheme as that indicated, it is beyond all doubt the remarkable impresario to whom belongs the credit of having resuscitated the ancient glories of the Theatre Royal, Covent Garden.

I hope the genial manager of whom I am writing will forgive me if I disclose one or two little incidents arising from a deep-rooted superstition which he shares with many other people on the subject of peacocks' feathers. I do not know the origin of the fear that exists in certain minds with regard to these gorgeous and decorative plumes. Personally I think they are very beautiful, but let it not be supposed that I am a member of the Thirteen Club. Indeed, I willingly confess my inability to perceive in the act of spilling salt a feat calculated to provoke 
uproarious hilarity, while the adornment of a dinner-table with death's-heads and cross-bones seems to me in no way likely to add to the piquancy of the feast or increase the gaiety of the guests.

But I believe I am right in saying that the impresario's superstitious beliefs are confined to the multi-coloured feathers taken from the handsome and dignified birds, and that, unlike Anton Rubinstein, he has never had to send out into the street for an itinerant musician to avoid sitting down thirteen to table. Some years ago an unthinking scenic artist introduced the obnoxious feathers on a drop-curtain he had painted for the 'Lane.' On the curtain which was promptly made to take the place of this work of art, the painter might have depicted in glowing colours the consternation of his chief on making the horrible discovery.

On another occasion Madame Melba was opening in her manager's presence a number of congratulatory letters she had received on her birthday. Out of one envelope fell a birthdaycard. Picking it up with true managerial courtesy, Sir Augustus discovered to his dismay that the fateful feathers figured in the design. In another moment the card had been torn into 
small fragments, and the director breathed freely again.

One more incident. A damsel desirous of figuring in the ballet entered the sanctum of the manager with the view to an engagement in his ' annual.' Wretched girl! In a weak moment she had decked her hat with the dreaded plumes. With natural indignation 'Druriolanus' upbraided the thoughtless ballerina for appearing before him thus arrayed. Why, the luck of the house was imperilled! The security of the Christmas audiences was at stake! So the poor applicant had to leave without having negotiated anything. But she came again-this time minus the feathers -and the great man, who is nothing if not goodhearted, engaged her without further ado. She had given him her word that the obnoxious hat had been relegated to limbo. 


\section{CHAPTER XLVI. \\ OPERATIC CONDUCTORS.}

Signor Arditi-Cavalleria Rusticana in London-Il Bacio

-An interpolation in Il Barbiere-Hïnsel and GretelOperatic morning concerts-Conductors in demandBevignani and Vianesi-Mapleson's perspicacity-Alberto Randegger-Carl Rosa as conductor-Visit to the United States_'Love at first-sight'-Madame Parepa-Courtship on the steamer-Beginnings of the Carl Rosa opera - English opera a success-Popularization of good works - Carl Rosa in Paris-Fatal visit-The influence of personality-Revived furtunes.

I Now come to conductors who have been principally connected with Italian opera. Amongst these Arditi took foremost rank. For more years than I could count he presided with conspicuous success over the principal orchestras, not only in England, but in America and on the Continent, and at all times his presence in the conductor's chair inspired every whit as much confidence in the artists on the stage as in the ranks of the instrumentalists under his control. Many popular 
operas were first produced under his direction, and, unless I am mistaken, the first performance in this country of Cavalleria Rusticana was conducted by him. As a composer, too, Arditi has written much that has retained its popularity to this day, notably the melodious Il Bacio, familiarized by Adelina Patti, and often introduced by her with marked effect in Rossini's Barbiere. Like the writer of these memoirs, the famous conductor is no longer young, but with the march of time his energy has in no wise forsaken him, and not long since I was greatly struck by the enthusiasm and spirit with which he performed his share in the London production of Humperdinck's delightful Hänsel and Gretel.

In the 'palmy' days - and nights-when London boasted the luxury of two opera-houses, and when the bare suggestion of converting one of them into a caravanserai would have pulverized its habitués, more conductors were required than at the present time. For, besides performances every night (in the season) at the two houses, there were frequent morning concerts, the programmes of which were so long that they might almost have stretched from the one theatre to the other, and in which the Italian singers used to appear, and make-some of them-a vast deal of 
noise. In fact, the more vocal disturbance they created the more delirious was the enthusiasm of their audience.

In connection with those days there are two conductors I ought to mention-Bevignani and Vianesi. The first-named, who married a niece of Mademoiselle Titiens, first appeared in this country as an accompanist, in which capacity he greatly distinguished himself. Mapleson, whose aptitude for discovering talent in young artists earned for him much respect, placed him at the conductor's desk. He made his mark at once, and soon became one of the most celebrated chefs d'orchestre. Moreover, his services were as much in request in Germany, Russia and America as they were in this country. Of Vianesi, suffice it to say that, hailing from Brussels, he was promptly welcomed as a valuable addition to the ranks of competent and skilled conductors, and that for several seasons he was engaged at the Royal I talian Opera, Covent Garden, with results that were eminently satisfactory.

At the present moment the chief of the conductors of the Royal Italian Opera is Signor Mancinelli, equally distinguished as a composer and as chef d'orchestre.

A word now for my old friend Alberto Randegger. More than forty years ago, when quite 
a young man, he came to court fortune in this country, and, as everyone knows, he succeeded in the attempt. As conductor, composer, and teacher of singing he has done wonders, and many are the vocalists who owe their present high position to his experience and ability, amongst others, Mrs. Mary Davies, Madame Clara Samuel, Miss Marian Mackenzie, and Mr. Ben Davies. His association with Italian and English opera performances has always been productive of good artistic results, and at the present day his experience as conductor is brought to bear with complete success on the Queen's Hall orchestral and choral concerts. He has been most happily identified, too, with the Norwich Festivals. Best known, perhaps, among his most successful compositions is his cantata Fridolin, produced at the Birmingham Festival. But, besides important works, he has written countless songs and unambitious pieces that have earned widespread popularity.*

* In connection with Mr. Randegger's association with the Philharmonic Society, it is worthy of note that a scena of his Prayer of Nature (Byron's words), was produced at one of the concerts in 1887 , and achieved considerable success. It is of interest, too, to recall the fact that he conducted for the first time in English the following operas: Carmen, Lohengrin, Tannhäuser, Esmeralda, and Nadeschda, the last two from the graceful and melodious pen of the late Arthur Goring Thomas. 
Carl Rosa, a very distinguished wielder of the bâton, was brought up as a performer on the violin, and as such achieved considerable success. As a young man he scented fortune in the United States, and, curiously enough, his doing so led to an exceedingly happy 'union,' resulting from that now almost antediluvian malady, 'Love at first sight.' For on the steamer that carried him across the Atlantic he made the acquaintance of a very charming English vocalist, to wit, Madame Parepa (the widow of Mr. Scarvel). In those days, when the voyage to the States was not accomplished in 'record' times, there were plenty of opportunities for a young couple to discuss matrimonial schemes, and the course of true love in this instance ran so smoothly that the young people got married in America, and shortly afterwards founded in the new country English opera under the style and title of the 'Carl Rosa Parepa English Opera Company.' Parepa Rosa, of course, became the prima donna-and a very charming one she proved to be-while her husband doubled the parts of manager and conductor.

The success that followed the inauguration of the scheme was instantaneous and thorough.

On leaving America, Carl Rosa and his gifted 
and amiable wife came to England, and started a similar enterprise, with the gratifying result that their operatic performances soon became a national institution. On the death of Madame Rosa, whose demise was universally regretted, both on account of her artistic worth and her endearing personal attributes, her husband formed a company to carry on the undertaking, and became the director thereof. It was an arrangement by which both the public, to whom the manager's name was a household word, and the shareholders benefited.

Good performances yielded good dividends, and to the founder and mainstay of the enterprise belongs the rare credit of being the only impresario who has ever made 'Englișh' opera pay in this country. He gave to provincial audiences during a long succession of years lyrical representations, complete and artistically satisfying in every detail, at reasonable and even cheap prices, and in this way popularized works which but for him would rarely have reached the ears of the multitude. $\mathrm{He}$ died in the prime of life, leaving behind him an extraordinarily wide circle of friends of every nationality. If I recollect aright he had gone to Paris in quest of a new work (his energy in the direction of obtaining the English rights of new 
operas was simply astounding, while he commissioned countless English composers to write works for his company), and contracted on the journey a chill, which ended fatally.

A few years prior to his death Carl Rosa had taken unto himself a second wife-a very charming and prepossessing lady. With his masterhand no longer there to direct affairs, and with the loss of his personality, fortune deserted the company which he had controlled so indefatigably and with such unerring discretion. His widow had no share in the management of the business, and for a long time the triumphs enjoyed by the company that bore her name were few and far between. About a year ago, however, Madame Rosa joined the board of directors, and from that time dates the renascence of part, at least, of the prosperity which marked the career of the enterprise during the lifetime of its initiator. That good fortune may long continue to attend an undertaking that has been so fruitful of good work in the past must be the sincere wish of all who have at heart the well-being of English musical art. 


\section{CHAPTER XLVII.}

\section{BRIGHTON ORCHESTRAL CONCERTS.}

The Orchestral Union-Frederick Kingsbury-J. T. Carrodus as leader-Some well-known instrumentalists-Mademoiselle Liebhart-The Brighton Concert Hall--Panoramas versus Polyphony-A small orchestra-Character of the programmes-Financial failure-Seats at sixteenpenceMrs. Stirling as a reciter-Midsummer Night's DreamSamuel Brandram-The Brizhton Dome-An increased orchestra-Madame L.emmens-Sherrington-Anna Thillon - Madame Schumann and some noted executants Falling off in receipts-Musical feast-Cowen's Symphony in $C$ minor-A boy composer-Brighton Sacred Harmonic Society-Mr. Robert 'Taylor-' Monday Pops' at Brighton-Lilliputian takings-A first and last attemptRoseate view of the future.

Is the autumn of the year i 868 , a number of excellent orchestral players, most of them Englishmen, banded themselves together under the style and title of the 'Orchestral Union,' and visited Brighton. This small but very efficient body of instrumentalists had for their conductor $\mathrm{Mr}$. Frederick Kingsbury, and the members consisted 
of players from the two Italian opera-houses in London, and also the Philharmonic Society. The late Mr. Carrodus was leader, and every one of the instrumentalists was well known in the musical world. There were Viotti Collins, Burnett, G. Collins, H. Chipp, J. Howell, Pratten, Barrett, Radcliffe, Hutchins, Harper, Hughes, Howard Reynolds, and others. Then there was a very accomplished vocalist in the person of Madame Liebhart, who, coming over to this country with a reputation gained at the Vienna Opera, made an instantaneous success, and became a great public favourite.

The Orchestral Union's performances took place in the Concert Hall, West Street, an institution which in after years renounced music in favour of a scheme of variety which embraced panoramic exhibitions and roller skating-attractions which brought within its walls audiences more numerous than those which had gathered to worship at the shrine of Mendelssohn, Beethoven, and the classic masters.

To revert to the orchestra, it was, as I have said, a small one. There were only four first and three second violins, all the other strings being in proportion, while the horns numbered two, and all the trumpet parts were played by the cornet. 
The programmes were made up of favourite overtures, parts of symphonies, operatic selections, and generally a couple of songs. There had been no similar entertainments in Brighton since the famous Jullien visited that town and gave promenade concerts. Nevertheless, the concerts were anything but a financial success. At that time, indeed, orchestral concerts never were, and it needed the attraction of a bright particular 'star' in the musical firmament to fill even a small room.

Notwithstanding the result of the first venture, I conceived the idea of engaging the Orchestral Union for the winter of 1869 , and giving a series of subscription concerts. They were to number fifteen, and the subscription for reserved seats for the entire series was fixed at one guinea. I am not a very good arithmetician, but I believe this worked out at the rate of one shilling and fourpence per concert.

For that sum I offered as vocalists, in addition to Madame Liebhart, who appeared the previous season, Madame Sainton Dolby, Miss Edith Wynne, the popular tenor Vernon Rigby, Lewis Thomas-then one of our leading bassos-and Sims Reeves. If my memory serves me, the fee of the last-named artist was at that time one hundred guineas for each appearance. 
In other respects I improved upon the first venture. For instance, I gave symphonies in their entirety, instead of in part only, and, with the exception of one operatic selection, the programme was composed wholly of classical works. Then I engaged the celebrated actress Mrs. Stirling to give a reading of Shakespeare's Midsummer Night's Dream, on which occasion the whole of Mendelssohn's incidental music was performed. I may here mention that I have seen the late Samuel Brandram stand up in Brighton before an eager, alert, and crowded audience, to recite this same masterpiece. But in the year I 869, neither the immortal name of the poetdramatist, nor that of the gifted and renowned actress who was to be his exponent, nor the additional attraction of some of the most beautiful music that has flowed from the pen of its composer, proved of sufficient interest to bring to the hall more than a scanty gathering.

As for the rest of the scheme, it embraced in the way of oratorios a performance of Handel's Messiah and one of Haydn's Creation. After what I have said, it will astonish no one to hear that the undertaking resulted in a serious deficit; but I nevertheless made up my mind to repeat the experiment, which I did in the following winter 
(18;0), when the concerts were transferred to the Dome, one of the finest concert-halls in the kingdom, although the building was not designed for entertainments of the kind.

I considerably increased the orchestra, doubling the strings and engaging, besides four horns, T. Harper, the finest trumpet-player then living. In addition to the vocalists who appeared in the first season, I secured the services of Madame Lemmens-Sherrington, Madame Anna Thillon, W. H. Cummings, George Perren, and Maybrick. Madame Sherrington, I may recall, had some time previously replaced Madame Clara Novello as leading soprano; and besides vying with that artist as an exponent of sacred music, she achieved conspicuous success in grand opera. Madame Anna Thillon had created quite a sensation in the forties by her personal attractions, the beauty of her singing, and the charm of her acting in light opera. In Auber's Domino Noir and Diamants dc la Couronne she created a veritable furore. When she appeared at my concerts it was after living some years in retirement. With regard to my other artists, musicians should need no reminder of the fact that W. H. Cummings* dis-

* Mr. Cummings, although he has disappeared from the ranks of public favourites, devoting himself now to the profes- 
tinguished himself greatly as a tenor, particularly in the interpretation of sacred works; or that George Perren also enjoyed for many years high repute as a tenor.

Among the instrumentalists I engaged were Madame Schumann, Madame Norman-Neruda, Joachim, Sainton, Piatti. Ernest Pauer, and Walter Macfarren.

In view of the enormous increase in the expenses I raised the subscription for the fifteen concerts from one guinea to a guinea and a half, and in doing this, having regard to the artistic value of the enterprise, I can hardly be said to have presumed too much on the financial resources of a public which many local prints had assured me was a music-loving one. This, however, was not apparently the view generally held. At any rate, many of my former subscribers marked their disapproval of a course which would have involved the expenditure of an additional eightpence per concert by withdrawing their support.

For the faithful ones there was presented a very fair musical feast, consisting of special Mozart. Beethoven, Schubert, Mendelssohn, and Weber

sion of teaching and to lecturing, is still held in the highest esteem by all musicians, to whom his extraordinary learning in matters appertaining to the art is well known. 
nights: a reading (with Beethoven's incidental music) of Goethe's Egmont, and another by Mrs. Stirling of Midsummer Night's Dream, as in the preceding year.

I was glad to be able, at one of the concerts, to procure a hearing for F. H. Cowen's Symphony' in $C$ minor, a remarkably fine work, the composer of which at that time was only sixteen years of age. The symphony was first given by Mr. Manns, at the Crystal Palace, where it won for young Cowen the approbation of all connoisseurs. On its production in Brighton the work was conducted by my young friend, who, even in those early clays, showed that he had thorough command of the forces under his control.

My scheme further comprised performances of the Messiah, Elijah, and Rossini's Messe Solennelle. I should here acknowledge the valuable assistance I received in the presentation of these works from the Brighton Sacred Harmonic Society, of which my old friend Mr. Robert Taylor was the accomplished conductor and guiding spirit.

One event in connection with that season I cannot overlook, both on account of its intrinsic importance, and its extraordinary monetary result. On February I4, the Monday Popular Concert took place at St. James's Hall, and, by arrange- 
ment with Mr. Arthur Chappell, I was able to put forward in Brighton on the following afternoon precisely the same programme interpreted by the identical artists. These were Madame Schumann, Joachim, Ries, Zerbini, Piatti, and a vocalist whose name I am unable to recall.

Alas! the Monday Popular Concert did not prove a Popular Tuesday Concert ; and in disclosing the receipts on that occasion I fear I shall lay myself open to the accusation that I am presuming on the gullibility of my readers. But I desire to do no such thing. The entire takings, apart from the small amount derived from the subscriptions (paid for the series), came to only a little over four pounds. Such was the result of my first attempt to popularize those unique and far-famed concerts in Brighton. It may almost go without saying that it was my last.

Unfortunately, this was not the only concert of the series at which my artists exercised their talents before a beggarly array of empty benches. In a word, the season was a complete fiasco, resulting in a loss heavier, in proportion to the increased expenditure, than that of the previous year. Nevertheless was I determined, encouraged by the congratulations-or, rather, the condolencesof my musical friends and the Brighton press, to 
persevere in my endeavour to develop in the town on which I had pinned my faith a love and practical appreciation of high-class orchestral concerts. With this object in view I set to work to extend the scope of the undertaking, and organize for the following year a scheme of sufficient magnitude to justify me in designating it a 'Musical Festival.' To some details concerning the first of these ventures, and those that followed in successive years, I propose to devote the next few pages. 


\section{CHAPTER XLVIII.}

THE BRIGHTON MUSICAL FESTIVALS.

First of the series-Works by English composers--F. H. Cowen's Maid of Orleans--Gounod in Brighton-First visit of Edward Lloyd - Miss Virginia Gabriel-Benedict's Tale of Fairyland-W. Sterndale Bennett-His dislike to public appearances-His last-Letters from the composer-Sir George Macfarren-J. F. Barnett and G. A. Osborne-La Pluie des Perles-F. Clay's Lalla KookhThe composer at work-Songs of Araby-Madame Sainton Dolby-A Deluge-And another-A disciple of Sullivan's-Alfred Cellier-Walter Macfarren-His first pupil-My nerves give way-Some interesting novelties -After eleven years-A few reflections-Final attemptMeeting of $1882--$ An Elijah cast-The RedemptionTestimonial from my subscribers-Disastrous losses-Unfulfilled pledges-A painful subject-A word about other English festivals-Why I renounced mine.

Is the following account of my Brighton Festivals, which commenced in $187 \mathrm{I}$, I will, in order to be as brief as possible, confine myself almost entirely to an enumeration of the principal new works I introduced to Brighton audiences, and some of the artists who were identified with the series. 
As to the first point, I may say it was my desire, from the outset, to emulate the example of $\mathrm{Mr}$. Manns at Sydenham, and produce, whenever the opportunity presented itself, works by English composers.

Looking back over the years that have passed since then, it is a source of pride and pleasure to me to reflect that the first composer who undertook to write an original work for me was my old and valued friend Frederic Cowen. For my first festival he wrote the incidental music to Schiller's Maid of Orleans, a work every page of which was marked by the grace, the facility of expression, and the beauty of orchestral effect which has distinguished every composition with which he has since enriched our musical art. The work, which he conducted himself, met with the greatest possible success.

So much for the first festival, and it will save a tedious amount of repetition if I state here that the pecuniary result of that enterprise, and of all the succeeding gatherings, was lamentably unsatisfactory.

Special éclat was lent to the meeting of 1872 by the presence of M. Gounod, who conducted many of his works, including Gallia (Lamentations of Jeremiah), his Messe Solennelle, and a 
short scena, Oh, Happy Home, which he had written expressly for me.

Let me here say that the scheme each year embraced performances of all the standard sacred works, and that among the musicians who testified their interest in the gatherings by coming, season after season, to direct the performance of their own opi were Sir Arthur Sullivan, Sir Julius Benedict. Sir Michael Costa, and Sir W. Sterndale Bennett. The names of those to whom I entrusted the rendering of these and other works I need not enumerate, save, in passing, one or two of them. Enough that they were artists whose names are honourably identified with all that is best in the musical art of this country and without whom none of our great festivals could be successfully carried out.

This serves to remind me that it was in 1873 (unless I am greatly mistaken) that my old and loyal friend, Edward Lloyd, was first associated with me in Brighton, and as I have not had an opportunity of doing so elsewhere, let me here briefly express the profound admiration I have always had for the voice, the style, and the exquisite refinement of our great English tenor. Let me also add that my association with the artist, who has attained to a position reached by 
few singers of his time, has always been of the most friendly and pleasant description.

Coming to the works I produced that season, Miss Virginia Gabriel, a very popular and tuneful writer of operettas, drawing-room pieces, and English songs, wrote for me a cantata founded on Longfellow's Evangeline, which proved highly successful. Another novelty I was instrumental in bringing to a public hearing for the first time was a scherzo for orchestra composed by Sir Julius Benedict, and entitled $A$ Tale of Fairyland.

Another interesting event was the performance of Sir W. Sterndale Bennett's sacred cantata, the Woman of Samaria. For some time I had been desirous of giving this beautiful and strangelyneglected work. With that view I put myself in communication with its distinguished composer, who readily and kindly promised to superintend the rehearsals, and should his health, which was then very precarious, permit it, conduct the performance.

Sterndale Bennett had a deep-rooted aversion to appearing on a public platform-a dislike easily to be accounted for from the fact that he was by nature a most modest and retiring man. $U p$ to this time he had not shown himself to the public 
Letry.18. 183

Seor hif Kuthe

I thants you bey enuch for your tinit inte, shich I rught thaue antwered hefore thi. I was orry not have been the rehearsal in London which I an Told was extreicely good - I hishe the in Brighton, hrssith ot tue Choralibletrons on Brebsoduy buening s $I$ alurzt fear 
that in the state of my health , (ties is Ian form grad, from oas wok) that \& may int actually he able to tats of the baton and face as lays fuller, but in, mos cave your ground Inter with tate any flake on most int make ain g the arrangement stich he would th es o the the present -

Believe ne. Sour aby Art

To face to 347 . 
for a great number of years, and it was therefore an act of kindness of which I was fully grateful that he should have come down to Brighton and personally supervised all the rehearsals of his work. When the day arrived for its performance he was so pleased with the intelligence and enthusiasm which the orchestra and chorus had brought to bear on the work, that he overcame his scruples, and to the surprise of all who knew him, and the delight of the interpreters, faced the latter with the conductor's bâton. When the career of Sterndale Bennett came to be written it was found that this was the very last appearance in public of a musician whose name is cherished to this day by all musical England.

Here I give a facsimile of the letter written by Sir Sterndale Bennett in reference to the visit to Brighton above recorded.

In recording the performance in 1875 of the then new oratorio, St. John the Baptist, by Sir George Nacfarren, I should, in passing, pay a tribute to the memory of this accomplished composer, who was not only one of England's greatest musicians, but one of the most charming and kindly men I ever met. As a writer his versatility was remarkable, for he not merely produced sacred works, symphonies, overtures, 
chamber music and the like, but several operas, of which Don Quixote and Robin Hood are perhaps best known. When Principal of the Royal Academy of Music-a post which he filled with such distinction-he was idolized alike by the professors and students of that institution.

In 1876 I gave two novelties written expressly for my festival. The first was a sacred cantata, the Good Shepherd, by J. F. Barnett-a work which I was proud to be able to produce; while the second was a 'festival overture' by G. A. Osborne, the composer of that famous piece, $L a$ Pluie des Perles, which has probably been played all the world over.

For the meeting of 1877 I had commissioned Mr. F. Clay, the writer of some charming light operas and songs (among the latter, She wandered dowen the Mountain Side, which was first sung at a concert of mine at St. James's Hall, by Madame Kellogg, a very accomplished American soprano), to compose a cantata. He chose for his subject Moore's legend, Lalla Rookh. While he was writing the score I frequently called upon him, when he showed me how he was progressing with the work. On one occasion of my visiting him he said, on my entering. 'Do, like a good fellow, glance through the paper for a few moments; I 
am just finishing a song for the cantata, and it won't take me five minutes.' He was as good as his word, and having put the last bar to paper. he played me the song. It was the beautiful and evergreen I'll Sing thee Songs of Araby. My delight on hearing this exquisitely melodious air was indescribable. To this day the song has remained one of the most favourite in the repertory of Mr. Lloyd, who sang it at the first performance of the work, while only last year Mr. Ben Davies created a sensation with it in Germany. I might mention that the composer presented my daughter with the manuscript of the song, which is now in the possession of Mr. Lloyd, who expressed such a great desire to have it that she gave it to him.

On its first production Lalla Rookh evoked a remarkable demonstration of enthusiasm, and at every subsequent performance of the work in England it won for the composer golden opinions.

That poor Fred Clay should have been cut oft from this world in the prime of his life and in full possession of his rare gifts is one of those things sorrowful beyond words.

The other novelty I produced was Madame Sainton Dolby's cantata, the Legend of St. Dorothea, reference to which I have made in an earlier portion of these reminiscences. 
I should here mention that I had organized a festival choir, in the training of which my old friend Dr. Alfred King was indefatigable. To his assistance I was greatly indebted, as I had been in previous years to the valuable co-operation of Mr. Robert Taylor, the director of the Brighton Sacred Harmonic Society.

The following works were written expressly for me in 1878 , and were produced under the direction of the composers: F. H. Cowen's oratorio, The Deluge; Walter Macfarren's Pastoral Overture; and a Suite Symphonique by Alfred Cellier, a musician whose untimely death deprived us of one of the most facile and graceful writers of light opera scores of modern times. True it was that this composer broke no fresh yround. He sat at the shrine of Arthur Sullivan. whose methods and mannerisms as exemplified in the Savoy operas he closely followed. But Cellier was no slavish imitator, and his scores were characterized by a delicacy and refinement which were absent from the pages penned by others who sought to emulate the incomparable collaborator of W. S. Gilbert.

A word for Walter Macfarren. $\mathrm{He}$ is one of the truest friends I ever had, and like his brother, the late Sir George Macfarren, he boasts con. 
siderable and varied attainments, being equally. at home as a composer, pianist, or teacher. In the latter capacity, indeed, he has hardly an equal. Oddly enough, my wife (when quite a young girl) was his very first pupil, and it was to his assistance that I looked on the anxious occasion, during the festival of 1878 , when my daughter made her first bow to an audience. She was to play Schumann's Concerto, and I had arranged to take the bâton. But when the time came I was. so nervous on the débutante's account that I had to relinquish the task, and Mr. Macfarren kindly volunteered to undertake the responsibility. And it was mainly to the generous encouragement he extended to the young player that her success was due.

Mr. Cowen's oratorio to which I have alluded was, by a curious coincidence, produced on a day upon which the title of his work was realized in an abnormal degree. From early morn till late at night the rain came down 'in buckets full,' as the saying goes, and the dismay wrought by the meteorological clerk caused many music-lovers to resist the temptation of sampling the orchestral 'deluge' prepared by the gifted young composer. Those, however, who were not drowned on their way to the concert-room reserved their. 
abuse for the aforesaid official, and lavished unstinted praise on a score that teemed with melodic and orchestral beauties.

All the subjoined works were written for this festival, and were conducted by their composers. A cantata founded on Sir Walter Scott's Lord of the Isles, by Henry Gadsby; a concert overture, in A major, by Thomas Wingham; another overture, Hero and Leander, by Walter Macfarren; a suite entitled Air de Danse, by Lindsay Sloper; and, lastly, a Concerto for Pianoforte and Orchestra in $C$, by William Shakespeare. This was played by my daughter, and conducted by August Manns.

The gathering of 1880 was also fairly prolific in new works. They included a sacred cantata, The First Christmas Morning, by Henry Leslie; ballet music by Arthur $\mathrm{H}$. Jackson, a very promising composer, who died young; an Organ Concerto in $E$ minor, by Ebenezer Prout; and a Symphony in B flat, by Walter Macfarren; all of which were given for the first time.

With the season of I 882 I come to the 'last of the Mohicans.' That I should not have renounced the scheme sooner, seeing that every development of it brought me further losses, may seem strange to those people-and there are a 
great many in this world-who believe in making money and not 'dropping' it. But even after two seasons of orchestral concerts and eleven of festivals, I determined to make one more attempt.

Alas, for vaulting ambition! Not satisfied with the tout ensemble of the previous ventures, albeit their completeness and artistic excellence had been generally admitted, I organized this my final festival on a more costly and elaborate scale than I had any of its predecessors, and engaged, besides the artists who had appeared in former years, Madame Albani and Madame Trebelli. Thus I was able to present the Elijah, with the following cast: Albani, Sophie Robertson, Trebelli, Edward Lloyd, and Santley. Remembering past experiences, I did not raise the prices of admission, but the room was more than half empty.

The most important event of the week was a fine performance under Mr. Randegger, by the same artists who had interpreted the work on its production two months previously in Birmingham, of Gounod's Redemption.* On this occasion the

* In I885 Mors et Vita, Gounod's sequel to the Redemption, was produced at the Birmingham Festival, and, with the able assistance of Mr. Randegger, I gave in the same year a 
attendance was good, but this was not sufficient to save me from a loss so heavy and disheartening as to make all idea of continuing the festivals impossible.

In fairness to my subscribers, I should here state that after one peculiarly disastrous season they generously presented me with a testimonial amounting to $£ 35^{\circ}$; but there was never enough enthusiasm shown by the inhabitants in the undertaking to justify me either in persevering with it single-handed, or in making a determined effort to obtain a guarantee fund-a course the desirability of which had often been suggested to me.

Every season had resulted in a loss averaging $£ 500$-sometimes a little more, at others a trifle less. The last of the series, however, by reason of the enormous increase in the expenditure, ended with a deficit of over $£ \mathrm{r}, 000$.

The abandonment of the festivals was to me an unspeakable disappointment, the more so as several composers were at the time under a promise to write for me works for production in

performance of the work in Brighton. The result was not such as to encourage me to give sacred works with a full orchestra, even at intervals, and to this day I have never repeated the experiment. Experientia docet. 
Brighton, notably Sir Joseph Barnby and Sir John Stainer.

I do not wish to dwell upon this matter except to say that no similar enterprise, to my knowledge, has ever been conducted at the risk of a single individual, and that the success of our principal musical festivals is, in some measure, due to the fact that the proceeds, if any, are devoted to local institutions and charities, whose welfare the inhabitants have at heart, and that the affairs are controlled by an influential committee who work with double zest from the reason that they make themselves responsible for whatsoever losses may arise. It is probable that those who supported me in the undertaking ciid so wholly from a love of art, and not because they philanthropically regarded me in the light of a useful or deserving charity.

But I would not have it be supposed that I am under the erroneous impression that England's premier festivals could not be held but for the extranecus motives that prompt the attendance of large crowds. I know full well, and gladly recognize, the love of music that exists among all classes in such towns as Birmingham, Leeds, Bristol, and the like, but I do believe that had the public on whom I had to rely been called 
upon to support those ill-fated festivals in the name of any large and popular local institutionchurch, chapel, or hospital-the result financially would have been very different.

An eloquent tribute this, no doubt, to the humane, religious, and philanthropic instincts of the British race. The reflection is not one, however, that mitigates the inconvenience arising from the loss of capital, or that encourages one to try and cultivate in others a love of art. 


\section{CHAPTER XLIX.}

PAST AND PRESENT-I845 AND 1895.

'Were the English a musical nation?'-A question never asked-Latter-day improvements-The old music-hall argument-Metropolitan concert-rooms in $1845-$ Hanover Square-IVillis's Rooms-Exeter Hall-Its danger in case of fire-The hall attached to Her Majesty's-Stipulations of the directorate-Sir Julius Benedict's concerts-The dearth of music in the winter season-Concerts given by professors of music-A convenient educational processEntertainments at private houses-Matineés musicales and 'at homes'-A quid pro quo-Signor Marras and J. Blumenthal-'Benefit' concerts_-The limited répertoires of artists.

IN an earlier portion of my musical jottings I have indicated the kind of entertainments that found favour with Londoners when first I took up my abode in their midst. In those days I never, as far as I can recollect, heard the question asked: 'Are the English a musical nation?'

Be it remembered, however, that I am speaking of $\mathrm{I} 845$. In the fifty years that have passed since then, the changes that have come over the public 
in their tastes and predilections with respect to all branches of art have been wonderful indeed, and it would be quite outside the scope of these recollections to attempt any sort of analytical comparison. I will simply say that the improvement wrought as regards music alone has been prodigious, and, to all who love the art and wish to safeguard its interests, gratifying in the highest degree.

It is all very well for exacting and hypercritical grumblers to say that, as long as people prefer music-halls to classical concerts, the English race cannot claim to be musically educated and appreciative of what is good and sound and intellectually nourishing. The argument has been adduced again and again, and will continue to be heard so long as there are persons fatuous enough to advance it. People do not go to 'halls of dazzling light' in order to hear good music, any more than they read the police 'intelligence' (which, by the way, usually reveals constabulary stupidity) in the hope of discovering in the reports literary excellence and finish. They go to the variety theatres simply and solely to be amused, and, if possible, to forget amid the mirth of their surroundings the worries of a work-a-day world.

But I have strayed from my point, and, in my 
anxiety to assert the right of the present-day public to the title of music-lovers, have permitted myself a slight digression. In attempting a brief comparison between past and present in matters musical, I cannot do better than let a few facts speak for themselves, and those of my readers who have borne with me so far can then judge how far I am right in affirming that the difference between I 845 and I 895 is wholly in favour of the present generation, and, from one point of view, of those who minister to their artistic wants.

When I came to England there were few concert-rooms in the Metropolis. I can well remember the Hanover Rooms in the square of that name, and Willis's Rooms, an institution which has undergone many changes, and where at the present time (so I am informed) a well-cooked chop can be obtained for the modest outlay of a guinea or so.

Both the rooms I have mentioned accommodated six hundred people. Very frequently they contained a lesser number. Then there was Exeter Hall, a larger building, but so incommodious that even people as righteous as the pious folk who now take their pleasures within its walls occasionally gave vent to their feelings in language which was too picturesque to permit of its reproduction 
here. More than this, the hall—at which, I should have stated, oratorios were given-was built on the principle that no one who attended a concert was deserving of any protection from danger in the event of an outbreak of fire. The performances of the now defunct Sacred Harmonic Society were given at Exeter Hall, by reason of the fact that it contained an organ, and a platform large enough to accommodate an orchestra and chorus.

Attached to Her Majesty's Theatre was another concert-room-a small one-but this was only let on terms that involved the inclusion in the programme of the names of some of the artists who were appearing at the time at the opera-house. This meant, of course, a considerable outlay, and, as far as I can remember, the only concert-givers who made entertainments yield a profit at this annexe were Madame Dulcken, Madame Carrodori Allen, and Sir Julius Benedict, all of whom had such a host of friends that they really relied in no way on these occasions upon the support of the public. Their programmes were stupendous in length, and were made up, for the most part, of arias and excerpts from the repertory of the Italian singers.

In the winter months there were hardly any 
concerts at all, and Londoners, having been surfeited in the months of May and June with Italian dishes, certainly faced the musical starvation that followed with marvellous equanimity. Probably their fortitude and resignation were aided by a sense of copious favours to come when the season of lyrical banquets arrived again.

These favours were mostly conferred by professors of music, whose pupils took tickets for their concerts as regularly as they took their lessons-perhaps more so. And this unfailing regularity-pleasing alike to professors and pupils - really formed part of the latter's educational curriculum. The professors taught them how music ought to be sung, and then gave a concert, at which the Italian singers and other foreign importations knocked all the theories they had been taught on the head. By this means the ambitious and earnest students were impressed with the necessity of taking more lessons, and when the next season came round their masters never failed to give them an early opportunity of testing the progress they had made in the light of the achievements of the operatic 'stars.' They could gratify their curiosity in this direction on payment of the usual fee. It was always one guinea. 
In those days, too, a convenient and popular form of giving concerts was that adopted by many artists (mostly foreign), who were wont to gather round them an appreciative assemblage of friends at matinées held in private houses, the drawing rooms of which had to be dismantled for that purpose. But this responsibility devolved upon the domestics of the establishment, and not on the concert-givers, so that the latter were put to no trouble beyond that involved in trying to amuse their audience-a task in which they rarely succeeded. But they were the richer by $£ 200$ or $£ 300$, all the same.

The owners of the mansions in which these matinées musicales were held were very generous. They never dreamt of accepting any remuneration for the loan of their rooms and their servants, or the subsequent provision of tea, coffee, and ices, with which the audience and the artists were regaled. But when they gave 'at homes' on their own account, their keen and artistic appreciation of the talent of the musical celebrities in whose interests they had previously dismantled their furniture, was such that they included them in their list of invites, and were overwhelmed with gratitude when their hospitality was returned by a song, a violin solo, or a brilliant display on the 
piano, which was rarely opened save on these occasions.

Very few artists at that time ever refused an invitation to an 'at home'; and their readiness in the matter of 'obliging' the hostess with musical contributions, thankfully received and never listened to, knew no bounds. Moreover, their good-nature was such, that when their turn came to give a concert they never failed to remind the kind ladies at whose houses they had performed of the artistic treat that was open to them if they chose to follow up the receipt of a programme with an application for two or three or more tickets. The application was invariably made; and it was never refused.

I would not have it be supposed, however, that every musician then in London was willing to sing and play about, right and left, on such implied conditions. Among the pleasant recollections of my early years in the Metropolis was the singing and playing of two charming artists, both of whom were very much in demand in social circles, and received terms commensurate to their great skill and high position. The one was Signor Marras, a favourite tenor and singingmaster; the other Jacques Blumenthal, admirable pianist, thorough artist, and a writer of who 
shall say how many melodious songs and piano pieces?

At the larger 'benefit' concerts the artists for whose benefit they were organized (by themselves) were not put to any very great expense. As a rule, they only engaged two or three performers, the rest of the programme being filled by others who gave their services. The concert-giver, of course, did the same for them when they gave entertainments, with the inevitable result that people who attended many of these musical functions invariably heard the same artists, and also enjoyed the edification of listening to the identical songs. The répertoires of the vocalists were generally limited. The patience of their hearers was the reverse.

Matters have changed since then. Nowadays, one of the few things rarely 'taxed 'is the patience of concert-goers. It was different in 1845 ; they had more money. Their wealth may have diminished, but their love of art has increasedat least, I think so. 


\section{CHAPTER L. \\ PAST AND PRESENT-I845 AND 1895. \\ (CONTINUed).}

Apathetic audiences and loquacious listeners-Talking during performances-What it enabled me to do-A party in Belgrave Square and my practical joke-The accommodation of old concert halls-The Brighton Town HallSingers' salaries in the forties-A Mario and Patti concert - Albert Hall concerts and a diva's terms -Sims Reeves then and now-Printing and advertising-Public ideas as to the cost of concert-giving-Peculiar impressions-An income-tax story-The writer as a millionaire-Why the Commissioners imagined him to be one.

I HAVE spoken of the lack of variety that characterized the répertoires of many artists when first I became acquainted with the musical life of London. That audiences should not have wearied of constantly hearing the same songs and the familiar pieces may appear strange to present-day frequenters of concerts and recitals. But it was mostly at private parties and drawing-room entertainments that people were treated to these repe- 
titions, and seeing that on such occasions the visitors were wont to engage in animated conversations and never ceased chattering the whole time that the musical programme was in progress, it mattered little or nothing what was sung or who the performer was.

I was once guilty of a practical joke in this connection. It was at a noble mansion in Belgrave Square, where I was engaged to play for the edification of a number of guests bidden to a crowded 'at home.' It happened that the very next day I was to perform at a concert in the Hanover Square Rooms, so the idea occurred to me that it would be good practice to play over the piece-a new one-for which I was put down in the programme of the morrow. I did so, to the accompaniment of the usual babel of voices, which made it even difficult for me to hear sometimes the notes I struck. Probably on this account I was rewarded with considerable plaudits, when, the piece over, I rose from the piano. When my turn came to play again I repeated the composition, knowing full well that, in the din of conversation which never flagged, the chances were ten to one against anyone discovering the repetition. And I was right. So high-pitched were the voices of the 'listeners,' and so incessant 
was their prattle, that it would have made no difference whether I played the Dead March in Saul or Tommy make Room for your Uncle. Yet a third time was I asked to give the guests a further opportunity of exercising their conversational powers to the accompaniment of my limpid strains, and I readily complied. But I stuck to the piece in the rendering of which I hoped to surpass myself at the next day's concert. Result, the same. Talk, laughter, final crash on the irongrand, followed by prolonged applause, mingled with cries of 'Charming !' 'Quite exquisite!' etc. The hostess, in particular, was lavish in the compliments she bestowed on me, and thanked me most effusively for the great artistic treat I had given her friends. Then it was that I asked her which of the three pieces I had played she liked the most.

'Well,' she replied, after duly considering the point, 'I think I preferred the second one. But,' she added, ' not that I didn't appreciate the others, only the second was so sweetly melodious.'

I told her I thought her discrimination wonderful. And so it was.

I have particularized the more important concert-rooms that existed when I was first in London. I may now add that they were all so limited in 
the accommodation they offered that had artists in those days commanded the terms paid to platform favourites in the present age, concert-giving would have been the shortest conceivable cut to the Bankruptcy Court. In proof of this I will give one or two instances.

In Brighton the largest concert-room in the forties formed part of the Town Hall. It held about 600 people. In I847 I gave a concert there, at which the artists were Grisi, Alboni, Mario, Fred Lablache (son of the great Lablache) and Julius Benedict. The combined services of these-the most distinguished performers of their day-cost me $£$ i 20. In i 86 I Adelina Patti sang for me in the same building, and the expenses of the concert (including the salaries of the other vocalists) amounted to no more than $\mathcal{L}_{\mathrm{I}} \mathrm{j}$.

Now for the other side of the picture. When the diva appears at the present day at an Albert Hall concert she receives $£ 800$, which represents, of course, only a part of the expenses. The artists who suppert her, I need hardly say, do not sing for nothing; and then there is the cost of the room and of the printing and advertising (very heavy items) to be reckoned with. In provincial towns, I may add, the same cantatrice commands $£ 500$ for each concert. 
Another example. The first time Sims Reeves appeared at a concert of mine in London I gave him, according to his terms, ten guineas. On the last occasion that he sang for me in the Metropolis he received 100 guineas.

With regard to printing and advertising, expenses in concert-giving have increased in the same proportion. When I first came to England there were not many newspapers, and advertisements inserted in them only ran to a few lines. Now, of course, the journals and periodicals of importance and influence are without number, and very often announcements for concerts and entertainments require the space of half a column and more.

And the strange part of it all is that the public seem to have no idea of the real cost and the enormous risk involved in these undertakings. Star singers and 'sensation' players, many people. seern to imagine, are so desperately fond of their art, and derive so much pleasure from appearing on a platform, that they apprise their services at the lowest possible value, and display in this matter a 'sweet reasonableness' which enables entrepreneurs who engage them to make large fortunes.

(Mem.: Will any manager who has reaped a 
large fortune out of concert-giving communicate with me and tell me how he did it?)

I will even go further and assert that I have known people foolish enough to labour under the hallucination that all artists perform for the concert impresario en ami; and I have astonished more than one such person with the assurance that this was a mistaken idea, and quite contrary to the usages of members of the musical profession.

The 'enormous' profits supposed to be derived from concert-giving were the cause a few years ago of a singular and rather amusing episode, in which I involuntarily figured. One morning I received an income-tax paper (a document with which I was painfully familiar), and on reading it I discovered to my amazement that my income had, for some recondite reason, been assessed at a very much higher rate than in any previous year. I could not repress a sigh at the reflection that my state of finances did not in reality justify the figures on the ominous blue paper, but the matter was one that called for action, and not cogitation, and I hastened, therefore, to put myself in communication with the authorities on the subject. In the result I went to see one of the commissioners (this occurred at Brighton) whom I 
knew well, and asked him to explain how the mistake had arisen. He solved the mystery by telling me that one of his colleagues had stated that I was insufficiently taxed (in this respect being, apparently, more favoured than anyone else in the three kingdoms) and that in reality my income was enormous. 'From what?' I asked in astonishment; 'from teaching or from concertgiving ?'

'From concerts,' was his reply. 'It was understood that every one of the three concerts you give during the season yields a profit of not less than $£$ i,ooo.'

Bewildered by the imaginary riches heaped upon me by the generous commissioners, I was at a loss in the first blush to know what to say. When I had sufficiently recovered myself from the shock of astonishment, I explained, with all the dignity demanded by the circumstances, that at the usual prices of admission the Dome, in which these fortune-yielding entertainments were given, held (when crowded) $£ 500$; that at the last concert I had organized the star vocalist received 175 guineas, and the other artists sums in proportion; that the hire of the room, and the printing, advertising and commission on the sale of tickets came to over $£ \mathrm{roO}$; and that the 
actual receipts (out of which all these expenses had to be paid) amounted to less than $£ 450$. I further volunteered the statement that at another of the concerts I had paid my diva $£ 500$, that the expenses totalled up to over $£ 700$, and that, although the prices for seats were increased, the receipts did not come to more than $£ 800$. On putting down these and other figures which I gave him, and duly pondering over the matter, my friend realized that the expenditure incurred by these undertakings scarcely left a margin for a profit of $£ \mathrm{I}, 000$, and I will do him the justice further to acknowledge that the explanation he subsequently tendered to the commissioners resulted in my income-tax return being reduced accordingly. 


\section{CHAPTER LI. \\ PAST AND PRESENT-I845 AND 1895 \\ (CONCLUDED).}

Programmes at miscellaneous concerts in the past-Days of trash-The taste of audiences half a century ago-An artists' room anecdote-Programmes of Gargantuan length--My own failings in this direction-St. James's Hall-An early Philharmonic concert-A performance at Her Majesty's in ' $51-A$ Covent Garden bill-Presentday operatic representations-A modern German fashion - A story about Cavalleria Rusticana-An uncanny Scot-English singers of to-day-Miss Maude Valerie White's compositions-Amateur orchestras-A sign of musical progress-The Duke of Edinburgh as 'first violin'-Musical education in this country-Then and now-The R.A.M.-Royal College of Music-Guildhall School of Music-Provincial musical institutionsBrighton School of Music.

I HAVE endeavoured to give some idea of the kind of musical entertainments that were tolerated when I first found myself in England. The programmes of miscellaneous concerts were for the most part made up of hackneyed operatic airs, 
ballads (few of the best kind), and instrumental solos of a character so trashy that anyone venturing to play them nowadays at a concert of any importance would run a serious risk of being hooted off the platform. But these were the things that used to find favour with unsophisticated audiences in the forties and fifties. They preferred quantity to quality, and would gladly sit out programmes containing enough items for three performances of reasonable length.

By the way, some years ago I gave a concert at which the last piece but one to be sung was a ballad entitled Ask Nothing More. It so happened that the programme was one of inordinate length, and embraced no fewer than twenty-six items. On looking down the list of contributions, one of the artists laughingly remarked that there was little likelihood that an audience which had listened patiently to twentyfour pieces would, like a famous little hero of Dickens, 'ask for more.'

But to return to concerts of a bygone era. Those given by Benedict used to last from halfpast one till seven, while, for my part, I must plead guilty to having given concerts in St. James's Hall and elsewhere which took four hours to complete. Possibly I might have in- 
flicted even more suffering on my friends but for the fact that there was a clause in my agreement with the proprietors of the hall to the effect that the programmes must be concluded by six o'clock, so as to enable preparations to be made for any evening entertainment that might follow.

I recollect a programme at one of the concerts of the Philharmonic Society which contained two symphonies, a couple of overtures, a concerto for piano, another for violin, and some vocal pieces. The audience remained to the end.

I also remember being present at a performance, in $185 \mathrm{I}$, at Her Majesty's Theatre, when Beethoven's now rarely heard Fidelio (with Cruvelli and Sims Reeves in the cast), two violin solos by Sivori, a divertissement by a troupe of Spanish dancers, and a long ballet constituted the attractions. Here was variety with a vengeance.

Another performance remarkable for its length was at Covent Garden Theatre, when Bellini's Norma and Mozart's Flauto Magico were given on the same evening. The artists were Grisi, Viardot, Mario, Tamberlick, Formes, and Ronconi.

Nowadays operatic performances in London are mainly long on account of the excessive length of the entractes. The subjects then dis- 
cussed by friends in the front of the house are of so profound and intellectual a character that justice cannot be done to them under half an hour or so.

I have noticed when in Germany on recent visits that operatic representations of extreme length are becoming the vogue again in the Fatherland. For example, such works as Traviata, Rigoletto, and La Figlia del Regimento, are frequently given there, together with shorter operas like Cavalleria Rusticana.

Mention of this last-named work brings to my mind a story I heard some time ago in Glasgow. It seems that Mascagni's melodious opera was being played at one of the theatres there by an English company, and under the title given to the English version. A Scotsman, evidently not belonging to the 'canny' order, saw a bill emblazoned with the words 'Rustic Chivalry, by Mascagni, to-night,' and immediately went off and imparted to his friends the strange information that 'something new' was to be given by the composer of Cavalleria.

Comparisons are proverbially odious, and I will therefore attempt none between the singers of the present and those of the past. But end-ofthe-century audiences have assuredly no reason 
to complain on the score of lack of talent. Take at random the names of some of our prominent English artists (Continental and American vocalists I will refrain from enumerating again): Macintyre, Clara Butt, Lloyd, Ben Davies (now as great a favourite in America and Germany as he is over here), Santley, Plunket Greene, Norman Salmond, Andrew Black, Douglas Powell, Iver McKay, Foli-to mention only a few who at once recur to one's mind. Of English pianists in I845 I only recollect Mrs. Anderson and Sterndale Bennett. At the present time pianistic notabilities are so numerous that there are scarcely concerts enough in which to find a place for them.

Of present-day composers I have written in a previous chapter. To the list already given, however, I should add that accomplished lady, Miss Maude Valerie White, who with a rare gift of melody combines the art of writing drawing-room songs in such a way as to command the attention and respect of connoisseurs. She is an artist to the tips of her fingers.

And while speaking of lady composers I cannot here refrain from paying my tribute to the rare and conspicuous talent of that charming, refined, and pre-eminently musicianly writer, Mademoiselle 
Chaminade, who rightly holds a foremost place in the affections of all amateurs of true discernment. As a pianist, too, she has established for herself a deservedly high reputation.

Another sign of our musical progress is the number of excellent amateur orchestras that now claim public notice. Too well known are these bodies to call for enumeration. Suffice it that they one and all help to supply a want that was sadly felt when I first came to England. I should add that among those who have done excellent and valuable work in furthering the cause of amateur musical art a conspicuous and honourable place should be assigned to the Duke of Saxe-Coburg-Gotha, who, as the Duke of Edinburgh, played for many years first violin in the Royal Amateur Orchestral Society.

A word for musical education in this country. When I arrived in 1845 the Royal Academy of Music was the only important institution of the kind in the Metropolis. Indeed. I might go further and say it was the only one in England. Moreover, it was by no means in so flourishing a condition as it happily is at the present time. Now London boasts, in addition, the Royal College of Music, the Guildhall School of Music, and institutions almost without number conducted 
on a smaller and less ambitious scale. Then, in all large cities, such as Edinburgh, Glasgow, Dublin, Manchester, and Liverpool, there are large musical academies, as indeed there are in smaller towns like Cheltenham and Brighton.

In the last-named, fifty years ago, it was only in large boarding-schools that any considerable number of pupils obtained musical education under one roof. And then they only took piano and singing lessons in the ordinary course of their curriculum, just as they were taught history, algebra, arithmetic, languages, and the like. Now the town in question boasts an admirablyconducted School of Music, which prospers under the able guidance of Dr. Alfred King, Mr. Robert Taylor, and Mr. Sydney Harper, and with a staff of professors which includes such accomplished musicians as Mr. F. Corder, Mr. Henry Davey, and my old and esteemed friend, Mr. Leopold Stern, father of the well-known 'cellist. I may say that I consider it a privilege to be associated with an institution so excellently managed and productive of so much good to earnest students of the art. 


\section{CHAPTER LII.}

MY SEVENTIETH BIRTHDAY AND MUSICAL JUBILEE.

Congratulations on December 10, '93-Loyal friends in and out of the profession-Letter from Sir Arthur SullivanMy birthday party - The testimonial - My Brighton friends-Ceremony at the Royal Pavilion-My jubilee concert in London-Committee and artists-An apology.

Os December 10, I 893 , I reached my seventieth year, and the anniversary brought me so many kind and congratulatory messages from old and young friends alike that I confess to having experienced some little pride at the spontaneous manifestation of good feeling that was made on that occasion. In the years that are left to me I shall always look back to that birthday and the heartfelt wishes it evoked from countless members of my profession with sincere pleasure, and, I think, justifiable pride. For that reason I cannot refrain from enumerating here a few of the letters 
10. Xee: 1893

1. QUEENS MANSIONS.

VICTORIA STREET. S.W.

hydear kuth.

Saids Scovet cance is

peras today, and offer you ney heartied capratur latan, f urtus for twany kaffer yeas to coun. Sut I a w chanud kere by wak, to affoic turents. and tumat kend a rabititute. labugs re collect unilh delight 
nur frequent areociation at orghton, ans your splenhic murieal achionemento "s that tow.

cligan fincel

Arehursullivion

To face p. $3^{81}$. 
that reached me on the morning of that, to me, memorable anniversary, from friends who were unable to attend my 'birthday party.'

From Sir Arthur Sullivan I received the graceful and sympathetic greeting, a facsimile of which faces this page.

I was also the recipient of felicitations from Sir Edward Lawson, who sent 'hearty congratulations and many blessings from all'; Colonel the Hon. W. Colville, Mr. and Mrs. Bancroft, Miss Liza Lehmann, Miss Esther Palliser, Signor Tosti, Mr. Clifford Harrison, Mr. W. Ganz, Mrs. Gilbert Hare, Miss Marianne Eissler, Mr. Leo Stern, Mr. J. M. Le Sage, Mr. A. Schloesser, Mr. Tivadar Nachez, Mr. Percy Betts, Mr. Learmont Drysdale, and many others.

Among many valued friends in my profession who were able to come in person to congratulate me were M. Paderewski, M. Sarasate, Mr. F. H. Cowen and Miss Henrietta Cowen, Mr. Walter Macfarren, Sir Joseph Barnby, Mr. Randegger, Mr. and Mrs. Eugene Oudin, Mr. Leonard Borwick, Mr. Santley, Mr. and Mrs. Norman Salmond, Mr. Otto Goldschmidt, Mr. and Mrs. Felix Moscheles, Madame Lemmens Sherrington, Mr. Vert, Mr. and Mrs. W. H. Brereton, Mr. Albanesi, Mr. W. Shakespeare, Mr. Daniel Mayer, 
Mr. and Mrs. Douglas Powell, and Mr. A. P. Hipkins.

It was also my good fortune to be made the recipient of a birthday testimonial, the movement in connection with which originated among some loyal friends in Brighton, in which town the presentation was made by the Mayor (Sir Joseph Ewart). Accompanying it was an address couched in the following terms :

'Royal Pavilion, Brighton,

'June 23, I894.

' Dear Mr. Kuhe,

' On behalf of the subscribers to the fund raised for the purpose of commemorating your great services to the cause of music, on your having attained your seventieth birthday, we, the undersigned, have been deputed to request your acceptance of the accompanying cheque for 450 guineas, as a token of the esteem and respect in which you are held by a large circle of friends, and as a mark of their gratitude for your lifelong devotion to the development and improvement of the musical art, especially in this town, where for so many years you were a resident among us. That you may be long spared to enjoy the blessing of unimpaired health, and to continue the pursuit 
of your professional work with undiminished vigour for many years to come, is our sincere wish and fervent hope.

'We remain, with warm regard, dear Mr. Kuhe,

'Yours sincerely and affectionately,

(Signed) 'Joseph Ewart, Mayor of Brighton.

'C. B. Woodruff, Chairman of the Hove Commissioners.

'Sidney Harper, Hon. Secretary.'

My Jubilee concert to commemorate the fiftieth year of my residence and musical career in this country took place at the Queen's Hall, Langham Place, on the afternoon of May 28, I 894. It was organized by a committee composed of the following: The Earl of Lathom, Sir Edward Lawson, Sir Arthur Sullivan, Sir George Grove, Sir Charles Hallé, Sir Joseph Barnby, Sir Augustus Harris, Madame Adelina Patti, Signor Nicolini, Sir Henry Irving, Mr. S. B. Bancroft, Sir A. C. Mackenzie, Professor Villiers Stanford, Dr. Hubert Parry, Mr. Sims Reeves, Mr. Charles Santley, Mr. Edward Lloyd, Mr. Ernest Gye, Mr. Arthur Chappell, Mr. F. H. Cowen, Mr. Alberto Randegger, Mr. Wilhelm Ganz, Mr. Henry Evill, Mr. D. Mayer, and Mr. N. Vert. 
The artists who appeared on that occasion, and all of whom generously gave their services, were : Madame Albani, Miss Esther Palliser, Miss Liza Lehmann, Miss Dale, Madame Antoinette Sterling, Madame Alice Gomez, Miss Clara Butt, Mr. Edward Lloyd, Mr. Eugene Oudin, Mr. Santley, Mr. David Bispham, Mr. Douglas Powell, Mr. Norman Salmond, the Meister Glee Singers, Madame Sophie Menter, Signor Simonetti, Master Huberman, Mr. Leo Stern, Mr. Henry Bird, Mr. Lane-Wilson, Mr. Randegger, Mr. Ganz, and Mr. George Grossmith. My old and staunch friend Sims Reeves, one of the first to ask to be identified with the concert, was, to everybody's regret, prevented through severe illness from taking part in the programme.

To the kind and loyal artists who rallied round me on that eventful afternoon, and to the countless friends who by their presence on that occasion testified to their regard and-let me believe - affection, I take this opportunity of publicly expressing my sincere gratitude and thanks.

One word in conclusion. I prefaced these memoirs with a promise to refrain, as far as possible, from alluding in its pages to myself, and I 
feel that, in writing of the events just recorded, I have laid myself open to the charge of having forgotten that pledge.

But I felt that I could not close these reminiscences without making some acknowledgment, however inadequate, of the cordial and generous and sympathetic attitude of those who helped to make the two commemorations of which I have spoken the success they happily were. So perhaps, after all, it is not necessary for me to conclude with an apology to my readers.

Rather, I fear, will the latter owe themselves an apology-for reading these memoirs. 



\section{N D E X.}

A.

ADELAIDE, Dowager Queen, 74

Africaine, $l, 126 n$, 171

Albanesi, Signor, $3^{82}$

Albani, Madame, 38, 85, 184,205 et seq., 313, 353, $3^{8} 4$

Albert Hall, 195, 196, 276

Alboni, Madame, 45, 92, 102, 146, $178,184,368$

Allen, Carradori, $41,42,46,360$

Alvars, Parish, 4I, 47, 48

Anderson, Mary, 296

$$
\text { , Mr., } 120
$$

André, I 87 Mrs., I20, 377

Angoulême, Duchesse d', 3

Anna Bolena, II7

Arbos, Señor, 150

Arditi, Signor, 328

Arnold, Sir Edwin, 298

Ashdown, Parry, 112

Auber, 175, 176, 206, $33^{8}$

Austria, Emperor of, 323

\section{B.}

Bach, 79, 107, 208

". Choir, 275

Bache, Walter, 145

Balfe, Michael, 7I, 75, 89, 92, I24, $146,253,312$

Balfe, Victoire, $75 n$.

Bancroft, Mr., 296. 381

$$
\text { Mrs., 296, 298, 381, } 3^{83}
$$

Barbiere, $I l, 156,175,180,184 n$., 186,328

Barnby, Sir Joseph, 355. 381, 383

Barnett, I. F., 270, 348 ," Morris, 40, 296

Barrett, Mr., 335

Bayreuth, 27

Beale, Frederic, 43, 45, Ico, 3 II

"Willert, 45, 244

", and Company, II $_{3}$
Beethoven, $4,44,93,167$, III, 127, I32, I42, I58, 208, 273, 335, 339, 340

Beethoven Rooms, 47

Bellini, 37, 209

Benedict, Sir Julius, 37, 46, 71, 76, $78,79,95,150,253,254 n_{.}, 296$, 299, $345,346,360,368,374$

Benedict, Lady, 79

Bennett, Joseph, 27, 30r

, Sir W. Sterndale, 254, 255, 345 et seq., 377

Berlin Opera House, 66, 227

Berlioz, 16, 89, 105, 109, 278

Bernhardt, Sarah, I25

Bettini, Signor, 165

Betts, Percy, $3^{8 \mathbf{r}}$

Bevignani, Signor, 329

Bird, Henry, $150,3^{84}$

Birmingham Festival, 62, 93. 121

Bisaccia, Signor, 166

Bisnuarck, Prince, 172

Bispham, David, $3^{8} 4$

Bizet, 169, $185 n$., 206

Black, Algernon, 44

" Andrew, 377

", John, 44

Blagrove quartette, $I_{4} 8$

Blumenthal, J., 363

Bohemian Girl, 75, 124, 146

Bohrer, 28

Bojëldieu, II4 $n$.

Boosey, Messrs., $169 n$.

Borwick, Leonard, 29, 150, 38 I

Bosio, 123, 125

Bottesini, Signor, 87, 89

Bradlaugh, Charles, 220, 221

Braham, John, 52

Brahms, 27, 268

Brandram, Samuel, 337

Brereton, Mr. and Mrs., $3^{82}$

Bridge, J. F., 260, 26I

Brighton, 98 el seq. , 307 
Brighton Festivals, 29, 6I, 63, 268, 343 et seq.

Brighton Orchestral Concerts, 334 et seq.

Brighton Sacred Harmonic Society, 340,350

Brighton Theatre, IoI

British Army Quadrilles, 87, 88

Broadwood, Henry, 43

$$
\text { " Messrs., I13 }
$$

Broadwoods, The, 44

Bull, Ole, 241, 242, 257

Bülow, Hans von, I4t, I50, 266 et $\operatorname{seq} ., 278$

Bunn, Alfred, $3^{12}$

Burnett, Mr., 335

Butt, Clara, 275, 377, 384

Byron, H. J., 296

C.

Campanini, Signor, 206

Camp in Silesia. The, 66

Candia, Conte di, $199 n$.

Carmen, 169, 172, 185 n., 207, $330 n$.

Carr, Osmond, 209

Carrodus, J. T., 205, 335

Carte, D'Oyly, 316

Carvalho, Miolan, 147, 170, 171

Catarina Carnaro, 32

Caux, Marquis de, $160,179,296$

Cavalleria Rusticana, 315, 328, 376

Cavour, $199 n$.

Cecil, Arthur, 296, 298

Cellier, Alfred, $35^{\circ}$

Cerito, 92, 309

Chaminade, Mademoiselle, 378

Chappell, Arthur, 148, 149, 341, 383

Charles X., 2

$$
\text { Messrs., } 169
$$

Cheer, Boys, Cheer, 96

Cherubini, II 4 n., 127

Chipp, H., 335

Chopin, 23, 105, 107, III et seq., 138, 229

Chorley, Mr., 40, II3

Cioffi, Mr., 89

Claus, Wilhelmina, 120

Clay, Frederic, 348,349

Collinet, Mr., 89

Collins, G., 3.35

$$
\text { ,. Viotti, } 335
$$

Cologne Cathedral, 132

Colville, Colonel the Hon. W., 38r

Concordia, The, 139

Consort, Prince, 74, 93

Corder, F. H., 261, 262, 270, 379

Cosmopolitan entertainments, 105

Costa, Sir Michael, 56 et seg., 78, 92 ,

$252,253,256.296,345$
Costa, Raphaelo, 62

Covent Garden Theatre, 45, 59, 67, 90, 92, 97, I1 $8,122,153,154$, I70, 179, 194, 207, 210, 3II et seq., 319 et seq., 329, 379.

Cowen, F. H., 255, 256, 259, 270, $297,340,3+4,350,351,383$

Cowen, Miss, $3^{8 \mathrm{I}}$

Cramer, J. B., 44 " Messrs., 113

Crampton, Lady, $76 n$.

Creation, 18I, 209, 337

Crociato, $1 l, 4$

Cruvelli, Sophy, III, 375

Crystal Palace, 62, 87, 213, 265 et seq., $34^{\circ}$

Cummings, W. H., $33^{8}$

Cusins, Sir William, 120, 203, 255 , 270

Czar, The, 21 5

Dale, Miss, 384

D.

Dame aux Camelias, 125

Davey, H. J., 379

David, Ferdinand, 76

Davies, Ben, 330, 349, 377

Davies, Fanny, 29, 150,222

Davies, Mary, $33^{\circ}$

Davison, J. W., 40, 102, 149

Daily Telegraph, 103, 293, 300, 301

Delafield, Mr., $3^{\text {II }}$

Deluge, The, 350

Diamants de la Couronne, $33^{8}$

Dicey, Edward, 296

Didier, Nantier, I70

Dietrichstein, Prince, 25

Dinorah, 147, 155

Dolby, Charlotte, 93, 102, 245, 336,

Domino Noir, 338

Don Giovanni, 6, 8, 10, 24, 124, 126, 127. $157,158,187$

Don Pasquale, 25, 81, 83, I16

Don Quixote, 348

Donizetti, 81, I17, 167, 200, 209

Doré, Gustave, 178

Dreyschock, A., 27, I18, II9, 137 et seg.

Drury Lane Theatre, 51, 89, 96, 312 et sey., 321 et seq.

Drysdale, Learmont, 269, 38I

Duka, Dr., 145

Dulcken, Madame, 23, 40,46, 76 et seg., 101, 106, 360

Dumas, Alexandre, 105, 125

Duse, Eleonora, 125

Dvoràk, Anton, 257

E.

Eckert, I16

Edinburgl, Duke of, 78 
Egyptian Hall, I 51, I 52

Eibenschiitz, llona, 29, I50

Eissler, Marianne, $3^{81}$

Eli. 56, 252

Elijuh, 56, 77, $78 n, 93,209,340,353$

Elisir d'Amore, 186

Ella's Musical Union, 47,148

Elsler, Fanny, 309

Elvey, Sir George, $25+n$.

Engel, Louis, I78

Erard, M., 133

Erard (pianos), 133

Ernst, 105, IIO, 241, 242, 296

Esmeralda, 259, $330 n$.

Essipoff, Madame, 226. 278

Etoile du Nord, 67, 90, 147

Eugene Onegrin, 3 16

Evangeline, 346

Evill, Henry, $3^{8} 4$

Ewart, Sir Joseph, $382,3^{8} 3$

Exeter Hall, 52, 93, 276, 359, 360

Exhibition of ' 51 , I19

\section{F.}

Faure, Monsieur, I7I

Faust, 127, 165, I68 et seq., $185 n$., 167,194

Favorita, Lu, 9x, I $\mathbf{x}_{4}, 200$

Ferdinand, King of Bohemia, 3

Fidelio, 4, II I, I27, 375

Figlia del Regimento, 66, 72, 124, 376

First Christmas, The, 352

Fischoff, Professor, 139,140

Fla uto Araico, $12 \mathrm{n.}, 33,165,375$

Fledermaus, i 10

Floral Hall, $3^{\mathrm{r}} 3$

Florinda, 119

Flotow, 89

Foli, Signor, 377

Formes, Carl, 77 n., 24I, 257, 375

Fornasari, Signor, 38, 42

Forty, Miss, 78

Fra Diavolo, $126 n$, I7 1

Francis, Emperor of Austria, 2

Francis Joseph, Emperor, 5

Franco-Prussian War. 186, 205

Frederick the Great, 66

Freischiitz, 128

Friaz, Duchesse de, $76 n$.

Fridolin, 330

G.

Gabriel, Virginia, 346

Gadsby, Henry, 270, 352

Gaiety Theatre, 300

Gallery of Illustration, 47

Ganz, Wilhelm, 235, 277, 278, 30x, 384

Garcia, Manuel, 185, 187 et seg.
Garcia, Madame, 187

Viardot, 184 et seq.

Gardoni, 74, 9r

Gassier, $x 70$

Gayarré, $126 n ., 315$

George IV., 99

Gernian Emperor, 228, 324

, Edward, 262, 263, 270

, Opera, 321

Gerster, Ethelka, 296

Gilbert, W. S. , 247, 289, 350

Giuglini, 125 et seq., I 400, I 70 et sey., 184

Goddard, Arabella, 120, I 50, 222

Godefrois, M. , $4^{8} n$.

Goethe, $17.3,34^{\circ}$

Goetz, Mrs., 5o, 2 I 5

Golden Legend, 209, 247

Goldschmidt, Otto, 274, 275, 381

Gomez, Alice, 384

Good Shepherd, $34^{8}$

Gotrlieb, Madame, I2

Gounod, 147, 168 et seq., 185 n., 206, $3+4$

Grafton Galleries, 27 I

Grain, Corney, 46, 282 et seq., 288 et seg., 296, 298

Gras, Dorus, 89

Graziani, Signor, 170

Greene, Plunket, 377

Grieg, Edvard, 257

Grisi, Carlotta, 92, 309

, Giulia, 38, 42, 45, 83, 92, 190, I91, 199, 204, 368, 375

Grossmith, George, 18, 46, 282 et seq., 289 et seq. , $298,3^{84}$

Grove, Sir George, 272, 273, $3^{83}$

Gruneisen, Mr., to

Guildhall School of Music, 277, 322, 378

Guillaume Tell, 175, 185 $n$.

Gye, E., $3^{8} 3$

, F., 67, 122, 153 et seq., 179, I94 $n ., 200,202,312$ et seg.

H.

Hallé, Sir Charles, 106 et seq., 109 n., I $49,150,278,3^{8} 3$

Lady, i5o

Hambourg, Max, $238 n$.

Hamilton, Miss, 178

Hamlet, 194, 288

Handel, 93, I40, 208, 260, 337

Festival, 62, 270

Hanover Square Rooms, 50, 109, 142, 212, 359, 366

Hiz̈nsel and Gretel, 328

Hanslick, Edward, 27

Hare, Gilbert, $38 \mathrm{I}$

, John, 296 
Harper, T., 335, $33^{8}$

,. Sydney, 379, $3^{8} 3$

Harris, Sir Augustus, 259, 296, 318 et seg., 383

Harrison, Clifford, 312,381

Hauk, Minnie, 2c6

Hausmann, to

Haydn, 18x, 208, 337

Heine, Heinrich, iI $n$.

Heller, Stephen, II2, I42

Henry VIII.. 234

Henschel, George, 275, 276

Her Majesty's Theatre, $37,56,59,68$, $82,91,92$, III, I I6, I21, I23, I24, 159, 170, 190, 192, 194 $n ., 253,311$, $3{ }^{1} 3$ et seq., 375

Hero and Leander, 352

Hérold, II $n$.

Hildebrand, Herr von, II

Hiller, Ferdinand, 142

Hipkins, A. J., $45,3^{82}$

His Excellency, 289

Hofmann, Josef, 235 et sey.

Hogarth, W., 40

Hohenlohe, Cardinal Prince, 13

Hohenzollern-Hechingen, Prince of, I43

Holland, Henry Scott, 7 I

Hollingshead, John, 296

Holmes, Henry, 270

Homburg, I IO

Hook, Theodore, 289

Howell, Mr., 89

1. Edward, 335

Hubermann, Master, $3^{8} 4$

Hueffer, Dr., 235

Hughes, MIr., 89, 335

Huguenots, Les, $4,28,126,127,163$, I85 $n, 186$

Hunmel, 20, 32

Huniperdinck, 328

Hutchins, Mr., 335

Hymn of Praise, 79, 209, 253

I.

Illustrated London News, 103

Imperial Institute, I IO

Irving, Sir Henry, 86, I95, 201, 263, $297,298,383$

Italy, King of, 203

Ivanhoe, 247, 317

$\mathrm{J}$.

Jackson, A. H., 352

Jarrett, Henry, $2+1$

Jessonda, 240

Joachim, Dr., 105, 150, 189, 240, 339, $34 \mathrm{I}$

Jones, Whitford, 89

Jullien, 86 et seq. , 336
$\mathrm{K}$.

Kalkbrenner, 20, 22, 23, 30, 105

Kean, Charles, 296, 298 Mrs. Charles, 296

Keeley, Mrs., $5 n$.

Kellerman, $4 \mathrm{I}$

Kellogg, Clara, 348

Kendal, Mr. and Mrs., 296

King, Alfred, 350,379

Kingsbury, Frederick, 334

Kingston, Beatty, $\mathrm{I}+2,30 \mathrm{I}$

Koenig, Herr, " 88

Kölnische Zeitung, 216

\section{L.}

Lablache, Madame Demeric, 165

$$
\begin{aligned}
& \Rightarrow \quad \text { Frederic, 84, 96 } \\
& 25,38,42,71,74,81 \text { et seq. } \\
& 86,92,119,147,309, \\
& 310,368
\end{aligned}
$$

Lachner, Franz, 32

Lago, Signor, 315, 318

Lalla Rookh, 248, 349

Lamonde, F., $27 \mathrm{o}$

Lara, Isidore de, 235

Lathom, Earl of, $3^{83}$

Lavigne, Mr., 89

Lawson, Sir E., 300, 301, 323, 383

. Lady, 30r, $n$.

i. Lionel, 300

Lazarus, Mr., 59, 88, 150

Lefort, Jules, 178

L.egend of St. Dorothea, 349

Lehmann, Miss Liza, 384

Leichtenberg, Duke of, I $43 n$.

Leipsic Conservatoire, 79

Lemaitre, Monsieur, 201

Lemmens-Sherrington, Madante, 335 , $3^{8} \mathbf{I}$

Le Sage, J. M., 300, 38I

Leschetizky, 226

Leslie, Henry, 270, $35^{2}$

Levi, Hermann, 279

[seq. ". Miss Angelina, 49

". Miss Florence, 294

.. Miss Matilda, 299

Liebhart, Madame, 335, 336

Lieder ohne Worte, I02, 136

Lily of Killarney, 299

Lind, Jenny. 38, 64 el seq., 77, 85, 9x, $92,99,111,116,117,123,124,154$, $184,188,274,275,279,3$ II

Lindid di Chamounix, is 6

Lindpeintner, 41,278

Liszt, Franz, 15, 21, 30, 112, 121, 130 et seq., 137 et seq., 158, 212, 223 , $238,243,263 \pi ., 279$

Litolf, Henry, 5o 
Lloyd, Edward, 225, 260, 345, 349, $353,377,3^{8} 3,3^{8} 4$

Lohengrin, 127, 206, $330 \mathrm{n}$.

Longfellow, 346

Louis, King of Bavaria, 21, 32

Lucca, Pauline, 171, 172, 296

Lucia, 38, 39, 51, 66, 89, 159, 193, 194

Lucombe, Emma, 50, $24^{2}$

Lucrezia Borgia, 38, 127, I91, 206

Lumley, Benjamin, 123, 124, 254, $308 \mathrm{et} \mathrm{seq}$.

Lurline, 312

Lutzer, Jenny, $3^{8}$

Lyceum Theatre, 122

Lytton, Lord, 242

\section{M.}

MacCunn, Hamish, 270

Macfarren, Sir George, $347,35^{\circ}$

Macfarren, Walter, 25I, 270, 339, $35^{\circ}$ et seq., $38 \mathbf{I}$

McKay, Iver, 377

Mackenzie, Sjr Alexander, 245, 256, $263,270,383$

Mackenzie, Marian, $33^{\circ}$

Macintyre, Margaret, 307, 377

Maid of Honour, 89

Malibran. Madame, 154, 185

Manchester College of Music, 108

Mancinelli, Signor, 329

Manns, August, I49, 189, 264 et seq., $340,344,35^{2}$

Mapleson, J. H., 159, I64, 169, 170, I $94, n$, 296, 3I, 329

Maria Padilla, 167

Marinion, Marje, 206

Marini, Signor, 92

Mario, 38, 39, 42, 45, 83, 92, 114 , 125, 126, 159, 17 et seq., 199 et seq., 368,375

Marlborough Club, 78

Marras, Signor, 363

Marseillaise, Iog

Martha, 89

Mascagni, Pietro, 315, 376

Massenet, 206

Mathews, Charles, 81 n., 296

Maybrick, $33^{8}$

Mayer, Daniel, 382, $3^{8}+$

May Queen, The, 259

Meister Glee Singers, $3^{8} 4$

Meistersingers, 280

Melba, Madame, 259, 325

Mendelssohn, 56, 59, 65, 76, 77, 79, $85,93,102,112,121,142,243,245$, $253,254,335,337,339$

Menter, Sophie, 223 et seq., 278, $3^{8}+$ , Karl. 223

Merry Wives of Windsor, $17 \mathrm{I}$
Messe Solennelle, 340

Messiah, 93, 128, 209, 337, $34^{\circ}$

Metternich, Prince, 31, 52

, Richard, 32

Meyer, Leopold de, 41,42

Meyerbeer, 4, 59, 65 et seq., 90, 126 $n$., I47, 155, 157, I7 I, 181, 185, 227

Midsummer Night's Dream, 337, $34^{\circ}$ Mignon, 194

Mikado, The, 19, 248, 249

Milanollo, Sisters, $243 n$.

Miranda, Comtesse de, 195, 196

Mireille, r6 $n$.

Molique, 33, fo, 43, 244, 245

Monday 'Pops,' 340, 34I

Monte Cristo, 105

Moriani, 39, 42

Mors et Vita, 353 n.

Moscheles, 20, 21, 37, 41, 42, 47, 76, $79,95,112,143,253$

Moscheles, Felix, $80 n$.

Motil, 279

Madame, $76,79,381$

Mozart, 6 et seq., 33, 120, 126, 158 , I $87,208,339$

Mozart (the younger), I2

Mühlfeld, Herr, 150

Murray, Mrs. Douglas, 283

Musicians' Corner, II $n$.

N.

Nachez, Tivadar, $3^{81}$

Nadeschda, $33^{\circ} \mathrm{n}$.

Napoleon III., I43 $n ., 179,180$

National Concerts, I 19

Naüdin, I26 $n$.

Gallery, 187

New Philharmonic Society, 277, 278

Nicolai, I7 I

Nicolini, 159, 173, 206, $3^{83}$

Nikish, 279

Nilsson, Christine, $166,173, \mathbf{1} 84,190$ et seq., 296, 298

Norma, 25, 38, 127, 375

Norman-Neruda, 339

Noruich Festivals, 330

Novello, Clara, 29. $33^{8}$

Nozse di Figaro, I16

Nye-Chart, Mrs. H., IoI

Oberon, 128

O.

Olivette, $3^{16}$

Ollivier, $1+3 n$.

Orchestral Union, $334 \mathrm{et}$ seq.

Osborne, G. A., $34^{8}$

Oudin, Eugene, $3^{26}, 3^{81}, 3^{84}$

Overland Roule, The, $15 \mathrm{r}$

Oxenford, John, 296 
P.

Pachmann, Vladimir de, 228, 229, 278 Paderewski, 150, 226, 230 et seq., $3^{81}$ Paganini, I4 et seq., 18, 239, 24I

Palliser, Esther, 381, $3^{84}$

Papini, Signor, 149

Parepa, Madame, 33

Paris, 22, 31, 48, 133,188

" Conservatoire, 159,205

. Opera, 16r, 180

". Opéra Comique, 147

,. Siege of, 175

Parry, John, 46, 47, ror, 15x, 28x

". Hubert, 260, 270, 383

Pärsifal, 27, $15^{8}$

Pasta, I17, 191, 199

Patti, Adelina, 38, 67, 92, 125, 154 et seq., 173, 180, 184, 186, 193, 207, $279,296,298,3^{1} 3,328,368,3^{8} 3$

Pauer, Ernst, 120, 339

Paxton, Sir Joseph, 264

Père la Chaise, II $n$.

Perren, George, 338, 339

Persiani, 92, 154, 31 I

Peter the Great, 67

Peter the Cireat, 90

Philharmonic Concerts, 62, 80, 93, I42, 254 et seq.

Society, 42, 253, 266, $330 \pi ., 335,375$

Piatti, Alfredo, 149, 150, 189, 296, 339, 341

Piccolomini, Mademoiselle, I23, I46, Pink Dominoes, 288

Pischek, 33 et seq., 39, 4I, 42, 77

Pleyel, 22

, Camilla, 30, 79, 120, 222

,. Salle, 133

Poniatowski, Prince, 179, I 80

Popper, Herr, 150, 223

Popular Concerts, The, 146 et seq.

Postilion of Longjumeau, I26n.

Powell, Douglas, $377,3^{82}, 3^{84}$

Prague Conservatoire, 7

Opera House, 6, 163

Pratten, Mr., 335

Proksch, Joseph, I9

Prophète, Le, 185, 186, 227

Prout, Ebenezer, 270, 352

Prume, 239, 240

Prussia, Queen of, 134

Punch, 3 r2

Purcell, Henry, 26r

Puritani, 37, $3^{8}$

Puzzi, Madame, I20, I2I

Pyne, Louisa, 312

Q.

Quatre Fils de Haymon, 75

Queen's Hall, 330, 383

"Theatre, 300
R.

Rachel, 123, 158

Radcliffe, Mr., 335

Raff, 268

Rahlen, Baron, 172

Randegger, Alberto, 329, 330, 352, $381,3^{8} 3,3^{84}$

Ravogli, Sisters, 315

Redemption, The, 353

Reed, German, 47

Reeves, Sims, 5I, 52 et sey., 86, 89, II9, 196, 203, 242, 296, 336, 369, $375,3^{8} 3,3^{8} 4$

Regondi, Giulio, 28

Reichardt, A., I05, 110

Reisenauer, A., 150,238

Reszke, Jean de, 126, 173, 260

Revolution of ' 48,104

Reynolds, Howard, 335

Richardson, Mr., 89

Richter, Hans, 279, 280

Ries, Ferdinand, 44

, Joseph, 44

"Mr., I50, 34I

Rigby, Vernon, 336

Rigoletto, $185 n$., 376

Robert le Diable, 68

Robertson, Sophie, 353

Robin Hood, 348

Roche, Madame, 112

Rockstro, W. S., 7r

Rode's Air and Varintions, II6

Romberg, 28

Ronconi, Signor, 375

Rosa, Carl, $317 n_{.,} 33^{\mathrm{I}-333}$

". ," Company, 259; Opera,

Rosati, 92

Rose, Frederick, 44

" George, 44

Rose of Castile, $3 \mathrm{I} 2$

Rose of Sharon, 263

Rosenthal, Moritz, I 56,338

Rossi, Count and Countess, 115,311

Rossini, 59, 84, 92, 93, IIt $n_{\text {., }} \mathbf{1 6}_{3}$, 164, 174 et seq., I84 $n ., 185 n$., 226, 328, 340

Royal Academy of Music, 63, 188 , $245,254,269,322,378$

Royal Ainateur Orchestra, $37^{8} \quad\left[37^{8}\right.$

Royal College of Music, 273, 322,

Royal English Opera, $3^{17}$

Royal Italian Opera Company, Ioo

Roze, Marie, 206

Rubini, 39, 200

Rubinstein, 30, 148, 150, 211 et seq. $230,231,232,236,278,279,296,298$ $\mathrm{S}$.

Sacred Harmonic Society, 62, 360

Saint-Saëns, Camille, 206, 234, 235, 278 
St. George's Hall, 287

St. James's Hall, 149, 166, 193, 213 , $232,287,307,340,374$

St. James's Palace, 74

St. John the Baptist, 347

Sainton, Prosper, 59, 245, 339

Sala, George Augustus, Io 3 ,. Madame, IO3

Salmond, Norman, 377, 381, $3^{84}$

Salvini, 2or

Salzburg, ix

Samson and Delilah, 234

Samuel, Clara, $33^{\circ}$

Santley, Charles, 78 n., I70, I7I, $353,377,3^{81}, 3^{83}, 3^{84}$

Sapellnikoff, 223

Sarasate, 255. 38I

Sartori, Madame, II I

Sauer, Emil, 150, 258

Sauret, Emil, 245

Savoy Operas, $2+7$

Saxe-Cobnrg-Gotha, Duke of, 272, 378

Saxe-Weinar, Grand Duchess of, 134

Scandinavian Symphony, 256

Scarvel, Mr., 33r

Schwarzenburg, Cardinal Prince, I3

Schlesinger, Max, 216, 217

Schloesser, Mr., $38 \mathrm{r}$

Schröder-Devrient, Madame, 4, III, 127, 201

Schubert, I40, 273, 339

Schulhoff, J., 27, 77, 94, 95, 105, 110, I 8

Schulhoff, Madame, 95

Schumann, 28, 65, 112, 273, 341 ," Madame, 29, 71, 150, 222, $339,34 \mathbf{r}$

Scott, Clement, 30r

Scottish Orchestra, 27 r

Sembrich, Madame, 296

Semiramide, $92,165,183$

Servais, M., 28

Shaftesbury Theatre, 315

Shakespeare, W., 268, 282, 352

Simonetti, Signor, $3^{8} 4$

Sivori, $87,2+3,244,375$

Sloper, Lindsay, $35^{2}$

Smith, Albert, 46 , 150 et seq., 281

Smith, E. T., 3rt

Sonnambula, La, 65, 76 n., 124, 153, 207

Sonntag, Henrietta, I 15 et seq., I24,

3II
Sothern, Edward, 296

Spectre's Bride, The, 257

Speyer, $4 \mathrm{I}, 4^{2}$

Spohr, 4 I, 2.40, 278
Staliat Mater, 77,176

Stainer, Sir John, 355

Stanford, Villiers, 260, 270, $275 n$., $3^{8} 3$

Staudigl, 39, $4 \mathrm{r}, 77 n$.

Stavenhagen, 238

Steinway pianos, 322

Sterling, Antoinette, $3^{8} 4$

Stern, Leopold, 379

Leo, $3^{81}, 3^{84}$

Stïrling, Mrs. , 337, 340

Stoker, Bram, 297

Strakosch, Maurice, 155, 160 et seq.

Strauss, Edward, I Io ," Johann, ro5, 109

,, Johann, junr., I ro

, Joseph, r ro

Stuttgart Opera House, 72

Sullivan, Sir Arthur, 78, 246 et seq., $257,259,269,273,295,317,345$, $350,379,383$

Sunday Times, 49, 293

Sweden, Queen of, r $43 n$.

Swoboda, 6, 7, 9, I I

Syinphony Concerts, 275

$\mathrm{T}$.

Taglioni, 92, 178, 309

Tam O'Shanter, 269

Tamberlik, 125, 126 n., I70, 375

Tamburini, 83, 92

Tannhüuser, $1_{57}, 182,330 n$.

Tausig, 223

Taylor, Robert, 340, 350, 379

Tedesco, J., 27

Thalberg, 21, 23, 24, 28, 45, 47, 48, 105, I17, I19, 133, 212, 296, 298

Theâtre Historique, I05

Thillon, Anna, $33^{8}$

Thirteen Club, 324

Thomas, Arthur Goring, 259, $330 n$.

Thomas, John, $48 n$.

, Lewis, 336

Times, The, I19, 124, 149

Titiens, Therese, 4, 126 et seq., 1. 6 , $165,170,184,311,329$

Tomaschek, Wenzel, r9, 26, 94

Toole, J. L., 296, 298

Traviata, 123 et seq. I 56, r92, 376

Trebelli, Antoinette, 166, 307 , Madame, 163 et seq., 170, I 84,353

Treffz, Jetty, 105, IIo

Tristan und Isolde, 1 58, 209

Troubadours, The, $263 n$.

Trovatore, $I l, 127,129,146$

Tschaikowski, 3 I6

$\mathrm{V}$.

Vanity Fair, 283

Verdi, 123, 124, 146, 18: $n$. 
Vert, N., 116, 220, 290, $3^{8} 4$

Vianesi, Signor, 329

Viardot, M., 186, 375

Victoria, Her Majesty Queen, 62, 74, $85,93,120,122,203$

Vienna Concerts, 30 , Conservatoire, 139

II Court Theatre, 323

Vieuxtemps, 41, 42, 87, I49

W.

Wachtel, $126 n$.

Wagner, Richard, 27, 157, 158, x82, $209,257,268,279$

Wales, Prince of, 62, 79

Wallace, William, 270, $3^{12}$

Walthew, R. H., 270

Wartel, M., I66

Weber, Carl Maria von, 7, 110, 278, 339

Webster, Benjamin, 296, $301 n$.

Wehle, Charles, 118

Weimar (Court of), I35, I 43

Weiss, Madame, $3^{8}$

Wessel, II2

When Other Lips, 147

White. Maude Valerie, 377

Whitehouse, Mr., I5o

Whitehurst, Mr., 249

Wieck, Clara, 28, 29
Wieniawski, 87

Wieniawski (pianjst), $94 \mu$.

Wigan, Mr. and Mrs. Alfred, 296

William, Emperor, I72

Williams, Montagu, 296

Willis's Rooms, 359

Willmer, Robert. 94, 95

Willyanıs, Mrs. Brydges, 195

Wilson. John, 282

Wilson-Lane, $3^{84}$

IVilton, Marie, 298

Windsor Castle, 321

Wingham, Thomas, 270, 352

Witgenstein, Princess, I $43, \mathrm{I}+4$

Wolff, Johannes, 150

Woman of Samaria. 254, 346

Woodruff, Mr., $3^{8} 3$

Wright. Frederick, 99

Wurtemberg, Queen of, 33

Wylde, Dr. Henry, 277

Wynne, Edith, 336

Yates, Ednund $\mathrm{Y}$.

Z.

Zauberfiöte, 33

Zerbini, 34 I

Zerr, Anna, 90

Zimnsermann, Agnes, 150

THE END. 



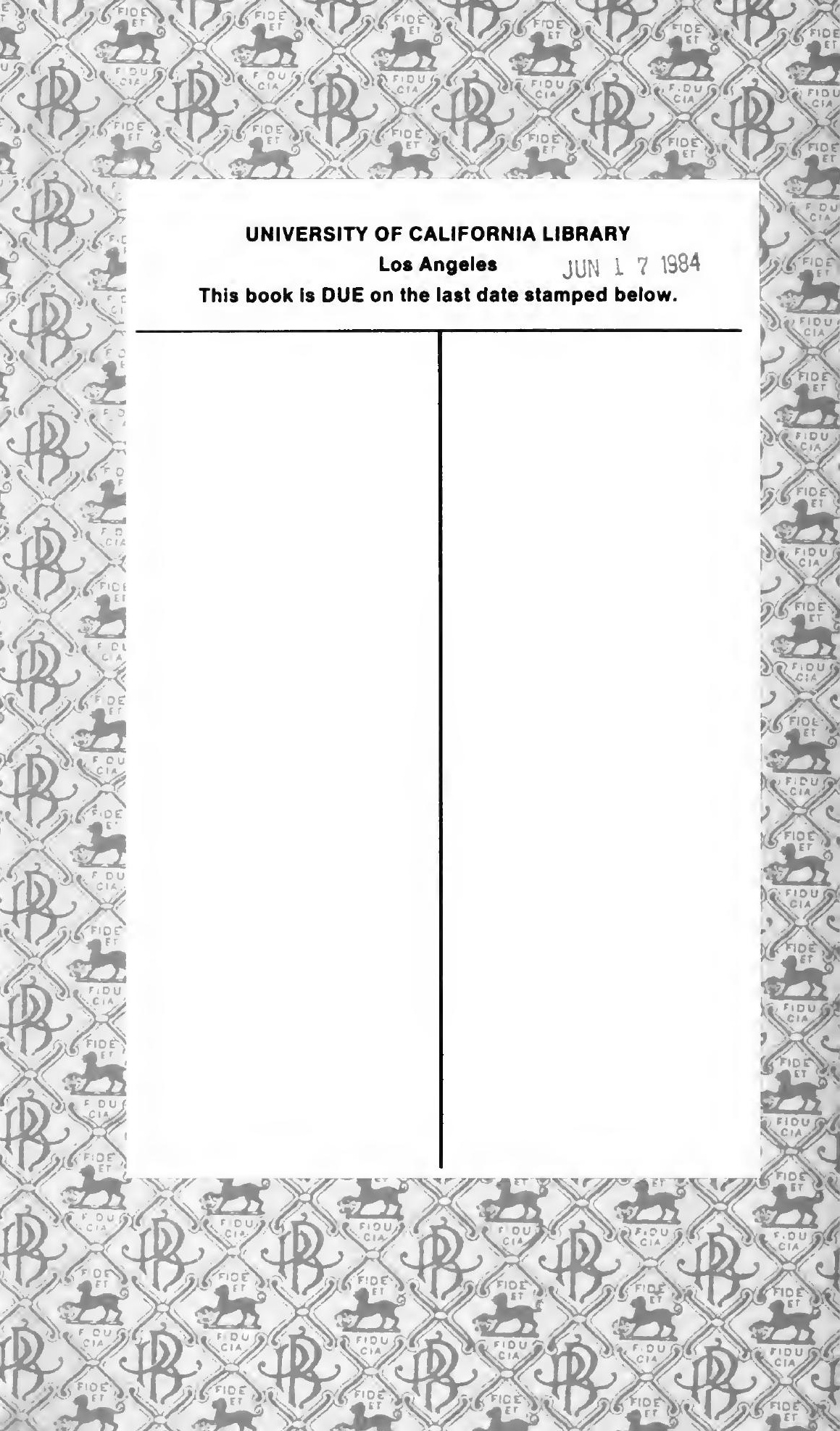


